Vilma Moreira Ferreira

A enunciação do cotidiano: estudo de textos de Clarice Lispector para o Caderno B do Jornal do Brasil de 1967 a 1973

Tese apresentada ao Programa de PósGraduação em Ciências da Comunicação da ECA/USP, como requisito para a obtenção do título de Doutor em Ciências da Comunicação, na área de Concentração Teoria e Pesquisa em Comunicação, na Linha de Pesquisa Linguagens e Produção de Sentido em Comunicação, sob a orientação da Profa. Dra. Terezinha Fátima Tagé Dias Fernandes.

ECA / USP

2008 


\section{Banca Examinadora}


Ao meu filho, Rafael, que é a riqueza de minha vida.

Aos meus pais. 


\section{Agradecimentos}

À Profa. Dra. Terezinha Fátima Tagé Dias Fernandes, minha orientadora, pela dedicação, pela paciência com que me orientou para que eu pudesse desenvolver este trabalho de pesquisa e pelo saber compartilhado nesses anos todos.

À Profa. Dra. Helena H. Nagamine Brandão e à Profa. Dra. Maria Lourdes Motter (in memorian), pelas sugestões feitas ao trabalho quando participaram da banca de qualificação.

Ao amigo Gutemberg, pela atenção, por todo incentivo e pelas informações compartilhadas.

Às amigas Sandra, Daniela, Jane, Sueli, Marli e ao amigo Vanderlei, que sempre estiveram presentes.

A Floripes Marinho Falcão, coordenadora do CPDoc-JB que deu suporte quanto ao material impresso de estudo e atendeu às minhas solicitações prontamente. Naldi.

À equipe da Biblioteca Nacional do Rio de Janeiro, especialmente a Ana

À equipe de bibliotecários da Biblioteca Mario de Andrade e da Biblioteca John Kennedy, pela atenção prestada.

Ao jornalista Alberto Dines pelas informações concedidas.

À grande amiga Lívia Brandão que está presente em todos os momentos. 
"Meu caminho não sou eu, é outro, é os outros. Quando eu puder sentir plenamente o outro estarei salva e pensarei: eis o meu porto de chegada."

(Clarice Lispector) 


\section{Resumo}

A tese teve como objetivo demonstrar a contribuição para o jornalismo brasileiro dos textos de Clarice Lispector escritos para o Caderno B do Jornal do Brasil entre 1967 e 1973, na relação com outros textos do jornal e na relação com os acontecimentos políticos, sociais e culturais da época.

Para realização da leitura dos textos, embasamo-nos na concepção de Mikhail Bakhtin sobre o enunciado concreto e nas peculiaridades constitutivas desta noção.

A leitura demonstrou traços do olhar jornalístico de Clarice Lispector quando escrevia sobre situações político-sociais vividas pelos cidadãos brasileiros diante dos fatos que aconteceram no cotidiano, num período marcado pela censura, a que se instalou após o golpe militar de 1964 e a posterior ao decreto do Ato Institucional n. ${ }^{\circ}$, em 1968. Seus textos reportavam os sentimentos de medo, de insegurança, de coragem, de covardia que se relacionavam com as questões de injustiça social, da perda de liberdade e outras questões ligadas à conjuntura político-econômica do País, acontecimentos exteriores com os quais Clarice Lispector enquanto intelectual e cidadã que conviveu e compartilhou com os outros cidadãos.

Palavras-chave: jornalismo brasileiro; jornalismo e linguagem; Clarice Lispector; Jornal do Brasil; Caderno B. 


\section{Abstract}

The thesis had the goal to demonstrate the contribution to the Brazilian journalism of the texts of Clarice Lispector written for Section B of "Jornal do Brasil" between 1967 and 1973 in relation to other newspaper texts regarding the political, social and cultural events from the period.

For the fulfillment of text reading, we based ourselves on Mikhail Bakhtin conception about the utterance and constituent features of this notion.

The reading has shown evidences of Clarice Lispector journalistic view when she wrote about political and social situations, experienced by Brazilian citizens facing facts that took place in daily life in a period imprinted by censorship, established after the 1964 military coup and subsequent decree of Institutional Act No 5 in 1968. Her texts reported the feelings of dread, insecurity and fearlessness related to social injustice matters, loss of freedom and other issues linked to the country political and economic state of affairs, external happenings with which Clarice Lispector as an intellectual and denizen coexisted and shared with other citizens.

Key-words: Brazilian journalism; journalism and language; Clarice Lispector; Jornal do Brasil; Section B. 


\section{Sumário}

Introdução

Capítulo 1 - Jornal do Brasil e o contexto político e cultural brasileiro dos anos 50 e 60.

1.1 A imprensa nacional: período de mudanças ..................................... 6

1.2 O Suplemento Dominical do Jornal do Brasil - SDJB .......................... 11

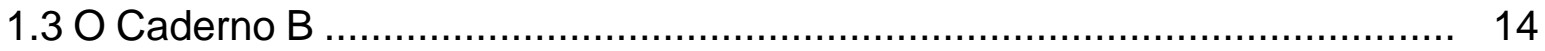

1.4 A produção cultural: manifestações e rupturas ...................................... 19

1.4.1 Manifestações: antes do golpe militar ........................................... 21

1.4.2 Crises e rupturas: o pós-1964 e o Al-5 ................................................ 23

Capítulo 2 - Clarice Lispector na imprensa: trajetória das revistas ao Caderno B

2.1 Escrevendo para o Correio da Manhã e o Diário da Noite. 26

2.2 Revista Manchete: Diálogos Possíveis com Clarice Lispector .... 29

2.3 Clarice Lispector: a coluna semanal no Caderno B 32

Capítulo 3 - A noção bakhtiniana de enunciado concreto

3.1 O enunciado concreto e a comunicação discursiva 36

3.1.1 Características constitutivas do enunciado concreto 39

3.1.1.1 A alternância do sujeito falante 39

3.1.1.2 Conclusibilidade do enunciado 41

3.1.1.2.1 Exauribilidade do objeto e do sentido 43

3.1.1.2.2 Projeto de discurso ou vontade discursiva do falante .................... 43

3.1.1.2.3 Formas típicas composicionais e de gênero discursivo .................... 44

3.1.1.3 A relação do enunciado com o próprio falante e com o outro ............... 49

3.1.2 A visão do texto como enunciado concreto ...................................... 53

3.1.2.1 O tempo e o espaço na construção dos pontos de vista ....................... 55 
4.1 Prece por um padre / Não sentir / Ir para / Daqui a vinte e cinco anos ....... 63

4.2 Medo do desconhecido / Dos palavrões no teatro / Chacrinha?! ................ 75

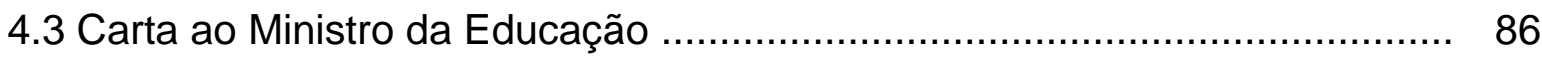

4.4 Medo da Libertação ..................................................................... 98

Considerações finais .......................................................................... 106

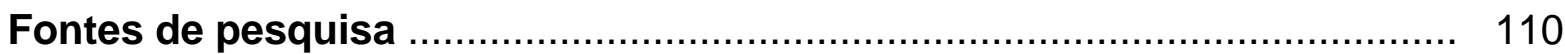

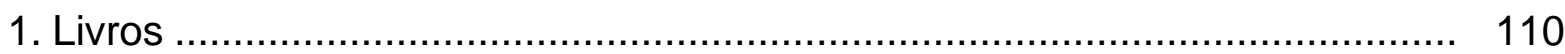

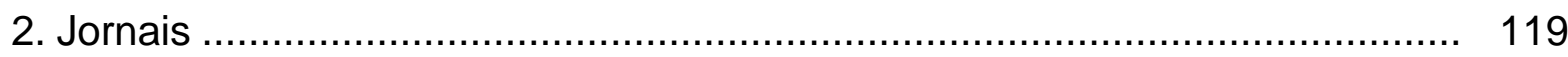

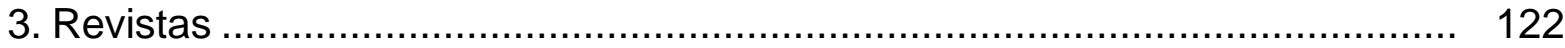

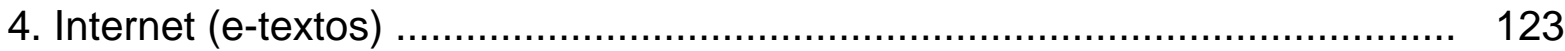

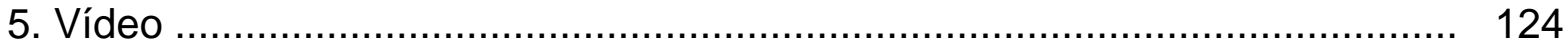

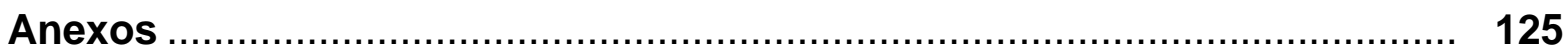

Anexo A - Outros textos de Clarice Lispector escritos para o Caderno B ........ 126

Anexo B - Coluna Clarice Lispector, publicada em 7 de outubro de $1967 \ldots \ldots . . . \quad 139$

Anexo C - JORNAL DO BRASIL. Rio de Janeiro, 7 mar.1967...................... 140

Anexo D - JORNAL DO BRASIL. Rio de Janeiro, 8 nov.1969....................... 141

Anexo E - JORNAL DO BRASIL. Rio de Janeiro, 17 set.1967...................... 142

Anexo F - JORNAL DO BRASIL. Rio de Janeiro, 17 set.1967 ....................... 143

Anexo G - Coluna Clarice Lispector, publicada em 7 de outubro de $1967 \ldots \ldots \ldots .144$

Anexo H - MICHALSKI, Yan. O teatro imoral, ou os corcundas por persuasão. 145

Anexo I - Coluna Clarice Lispector, publicada em 17 de fevereiro de 1967..... 146

Anexo J - JORNAL DO BRASIL. Do protesto à desordem. Rio de Janeiro........ 147

Anexo K - Coluna Clarice Lispector, publicada em 31 de maio d 1969............ 148

Anexo L - JORNAL DO BRASIL. Rio de Janeiro, 14 dez. 1968.................... 149

Anexo M - Paisagem com Pássaros Amarelos, de Paul Klee........................ 150

Anexo N - JORNAL DO BRASIL. Omissão. Rio de Janeiro, 22 jun.1968......... 151 


\section{Apresentação}

Esta tese tem como objetivo demonstrar a contribuição para o jornalismo brasileiro dos textos de Clarice Lispector escritos para o Caderno B do Jornal do Brasil entre os anos de 1967 a 1973.

Há muitas pesquisas acadêmicas relacionadas ao campo literário que se dedicaram a estudar a vida e a obra da escritora e foram importantes para o desenvolvimento de nossa pesquisa, porque a partir delas pudemos conhecer seu trabalho como ficcionista, seu trabalho para a imprensa, seu relacionamento com os amigos, com a família entre outros aspectos.

Entre essas pesquisas citamos, como exemplo, a de Nádia Battella Gotlib, Clarice - uma vida que se conta; a de Lícia Manzo, Era uma vez: Eu; a de Teresa Cristina Montero Ferreira, Eu sou uma pergunta que se constituíram da consulta da documentação e das correspondências pessoais da escritora que se encontram no Arquivo-Museu de Literatura Brasileira da Fundação Casa Rui Barbosa, no Rio de Janeiro, em outros arquivos públicos e em arquivos particulares.

Os três trabalhos biográficos citados inseriram textos de Clarice Lispector publicados no Jornal do Brasil; todavia, extraídos principalmente do livro $A$ Descoberta do Mundo, obra póstuma publicada em 1984, que reúne parte dessa produção.

O trabalho de Clarice Lispector no JB é visto por Gotlib $(1995,376)$ como "um extenso 'diário"' em que narra sua vida pessoal, seus afazeres domésticos e literários, sobre os amigos, os lugares que freqüentou, entre outros.

Manzo (1997) conta a vida da escritora através de sua própria literatura. Assim, a pesquisadora compõe seu trabalho a partir de trechos da obra literária de Clarice, inclusive dos textos publicados na coluna do caderno de cultura do Jornal do Brasil. 
Ferreira (1999) escreve a biografia de Clarice para contar os fatos que marcaram sua vida pessoal, sua atividade literária e sua atividade jornalística como cronista do $J B$, introduzindo trechos dos textos que o jornal publicou.

Além dessas pesquisas de caráter biográfico, destacamos outra a de Yudith Rosenbaum, que sob a perspectiva psicanalítica estuda a obra literária de Clarice e alguns textos que a escritora publicou no JB. Citamos um de seus trabalhos, entre tantos outros: No território das pulsões que compõe os Cadernos de Literatura Brasileira, edição especial de Clarice Lispector, no qual a pesquisadora analisa o texto A geléia viva como placenta que extraiu do livro A Descoberta do Mundo.

No campo da comunicação, a pesquisa de Cristiane Costa, em Pena de Aluguel, trata sobre os escritores jornalistas que trabalharam na imprensa entre 0 período de 1904 a 2004. Ela faz referência a Clarice Lispector como cronista que escreveu para o Jornal do Brasil com informações trazidas de outras pesquisas, como as biografias, mencionadas anteriormente, e o livro A Descoberta do Mundo.

Apesar de essas pesquisas apresentarem estudos sobre o trabalho de Clarice Lispector publicado no JB sob diferentes perspectivas, o diferencial, que se estabelece entre nossa pesquisa e as acima mencionadas, é que estudamos a relação dos textos de Clarice Lispector, escritos para o Caderno B, do Jornal do Brasil, com os textos do jornal e com os acontecimentos históricos, sociais e culturais da época, relacionando estudos de comunicação e teorias da linguagem com o apoio teórico da noção de enunciado concreto do pensador da linguagem Mikhail Bakhtin.

Assim posto, defendemos que os textos de Clarice Lispector escritos para 0 Caderno B, do Jornal do Brasil, complementam os demais textos desse jornal, dialogam com eles e comunicam outros aspectos dos acontecimentos da vida cotidiana que não eram noticiados e informados, no entanto, sempre estiveram relacionados à realidade social, política e cultural do país.

A contribuição que advém desta pesquisa para o jornalismo brasileiro está no fato de que os textos de Clarice Lispector no jornal têm permanência e permitem outras leituras que garantem a historicidade, o significado dos acontecimentos cotidianos que o cidadão vive e com esta vivência constrói a História social.

Somamos a isso o dizer de Rossi (1998, p.17) de que "a imprensa não vive apenas dos episódios ocorridos num determinado dia, mas também da discussão, 
do debate e da análise de acontecimentos ou situações intemporais - ou seja, que estão acontecendo, e não simplesmente que aconteceram."

Diante disso, para a realização do trabalho, decidimos fazer uma leitura diretamente dos originais do jornal que estavam no acervo da Biblioteca John Kennedy em São Paulo. Diante das edições do JB, descobrimos que seus textos eram escritos para uma coluna fixa localizada à pagina dois do Caderno $B$, um caderno de cultura de circulação diária.

Dessa leitura prévia realizada nos originais, tivemos a convicção de que o estudo de seus textos somente seria adequado se considerássemos a relação de interação com o jornal para o qual colaborava e o momento histórico em que foram escritos. Assim decidimos ir à Biblioteca Nacional do Rio de Janeiro para fazermos uma leitura mais atenta, inclusive porque a pesquisa se faria nas edições do Jornal do Brasil microfilmadas, o que facilitaria nosso trabalho.

Depois de realizar a leitura cuidadosa das edições do JB, do período de 1967 a 1973, constatamos que os textos tinham relação com os acontecimentos do cotidiano de forma explícita ou implicitamente. Além disso, notamos que abordavam temáticas diversificadas e se constituíam em diferentes formas de construção, sendo então possível fazer oposição às afirmações de muitos estudiosos de que Clarice Lispector escrevia apenas temas intimistas, femininos ou autobiográficos e que estes textos eram classificados de modo abrangente como crônicas. Na verdade, alguns deles se formavam a partir de trechos de algum romance ou de seus contos, outros integravam comentários, entrevistas, notas, prece, carta com tonalidades expressivas variadas.

Para isso, buscamos apoio na noção de enunciado concreto de Mikhail Bakhtin de modo que nos ajudou a perceber que os textos só podem ser compreendidos e estudados na relação com a situação extraverbal que está implicada no verbal e na interação com os interlocutores que compartilham das mesmas situações. O que nos exigiu fazer uma pesquisa histórica não apenas dos acontecimentos políticos da época bem como um estudo dos comportamentos e dos sentimentos dos cidadãos brasileiros naquele momento. Sendo assim, estudamos a ditadura militar, a censura, a repressão e o clima de tensão que marcaram o período.

Vimos também a necessidade de estudar a história do Jornal do Brasil e o Caderno B para conhecermos seu projeto de criação e seu papel para a história do jornalismo, no período que abrange a nossa pesquisa. 
Ressaltamos que a noção bakhtiniana de enunciado concreto possibilitou-nos estudar os textos por três fatores que os constituem: pelo conteúdo temático, pelo estilo e pela construção das formas típicas composicionais e de gênero do discurso. Com isso, foi possível constatar a pluralidade de gêneros discursivos em que foram organizados de modo a atender a finalidades comunicativas e expressivas específicas. A partir do estudo desses fatores pudemos fazer a seleção de alguns textos que pudessem ser representativos do trabalho de Clarice Lispector para o para o Caderno B a fim de realizarmos uma leitura verticalizada.

Ao estudarmos os textos que selecionamos para esta leitura, foi possível constatar que a diversidade de gêneros praticados nos textos da coluna de Clarice Lispector estava relacionada ao período em que eles foram escritos. Durante a repressão militar que se instituiu após o decreto do Ato Institucional n. ${ }^{5}$, em dezembro de 1968 e que instalou a censura nos jornais, Clarice, enquanto escritora de textos que foram publicados no jornal, escolheu formas diferentes de construção dos textos para comunicar e informar, por exemplo, sobre a censura e a perda da liberdade imposta aos cidadãos porque esses temas não poderiam ter sido comunicados de outra forma. No momento anterior ao decreto do Al-5, seus textos foram organizados pela escolha de outros gêneros discursivos, isso porque era outro o contexto extraverbal.

Para compor o corpo deste trabalho dividimo-lo em quatro capítulos:

No primeiro capítulo, tratamos das transformações político-econômicas e das manifestações culturais do país nos anos 50 e 60 para demonstrar que as mudanças ocorridas na imprensa nacional e, portanto, as do Jornal do Brasil estiveram em consonância com o momento vivido no país. Abordamos a criação dos suplementos, incluindo o Suplemento Dominical - SDJB e o Caderno B, sua criação e as mudanças realizadas que o consolidaram como caderno de cultura e que coincide com a chegada de Clarice Lispector ao jornal.

Dedicamos o segundo capítulo à Clarice, mais exatamente, a sua trajetória pelos jornais o Correio da Manhã e o Diário da Noite, colaborando para as páginas femininas. Descrevemos também seu trabalho para a revista Manchete em que publicou entrevistas na coluna Diálogos possíveis com Clarice Lispector. E, por último, sua colaboração para o Caderno B.

No terceiro capítulo, fazemos a abordagem teórica apoiada à noção bakhtiniana de enunciado concreto e suas características constitutivas: a alternância 
dos sujeitos falantes, a relação eu e outro, a conclusibilidade do enunciado (conteúdo temático, estilo, construção composicional e gêneros discursivos). Decidimos dedicar um capítulo completo à teoria por considerarmos o pensamento de Bakhtin relevante para os estudos da comunicação e para podermos assim estudar os textos de Clarice Lispector.

No quarto capítulo, apresentamos as etapas do estudo, a seleção dos textos exemplares escritos nos anos de 1967, 1968 e 1969 e a leitura que realizamos.

Inserimos nos anexos os textos de Clarice Lispector publicados no Caderno B, aqueles que foram mencionados e estudados durante o trabalho e outros textos do Jornal do Brasil. Todos estão apresentados na versão original em que foram publicados. 


\section{Capítulo 1 - O Jornal do Brasil e o contexto político-cultural dos anos 50 e 60}

\subsection{A imprensa nacional: período de mudanças}

Antes mesmo de tratarmos especificamente do Jornal do Brasil, iremos nos debruçar na trajetória de algumas mudanças pelas quais a imprensa nacional passou. Mudanças significativas aconteceram nos anos 50, marco de muitas outras, posteriores.

A imprensa, que em anos anteriores, dependia dos favores do Estado, de pequenos anúncios populares ou domésticos e da publicidade das lojas comerciais, em 1950, começava a investir no setor publicitário, e os anúncios nos jornais acabaram se diversificando. Tais mudanças revelavam o caráter comercial das empresas jornalísticas que se tornavam mais independentes.

Se a imprensa como empresa jornalística, nessa época, passava por mudanças, a práxis jornalística também. Desde o século XIX, o jornalismo era praticado por profissionais de outras áreas, principalmente, por intelectuais dedicados à literatura que não utilizavam técnicas específicas na elaboração dos textos publicados no jornal. O beletrismo e o estilo rebuscado estiveram presentes por muito tempo nos textos do jornal, nas páginas que o constituíam. Porém, com todas as mudanças que se seguiram, o jornalismo passou a ser mais profissional e exigia profissionais qualificados, com formação acadêmica. Segundo Faro (1999, p.75), desde os anos 40, com o surgimento dos cursos superiores de jornalismo, o jornalista, formado com embasamento teórico acadêmico estruturado, já não era mais o "profissional liberal autodidata com pendores literários" que também atuava como jornalista, mas passava a ter o ofício de "lidar com a informação de forma profissionalizada", era um profissional de imprensa. ${ }^{1}$

\footnotetext{
${ }^{1}$ Nessa época não havia a exigência de contratação desse profissional para o trabalho no jornal. Somente mais tarde, com a promulgação do Decreto-lei no.972 datado de 17 outubro de 1969, se oficializou e normalizou a profissão de jornalista.
} 
O processo de profissionalização ganhou força na década de 50 quando a imprensa importou o modelo americano de jornalismo e com isso mudou o estilo de fazer jornal. Novas técnicas foram introduzidas e permitiram formalizar os ideais de objetividade, de neutralidade e de imparcialidade, marcas de um modelo de jornalismo moderno que legitimaram a prática do jornalismo informativo. Os jornais criaram os manuais de redação, padronizaram técnicas como a do lead ou da pirâmide invertida que contribuíram para a concretização desse ideário.

As reformas que ocorreram nesse período representaram um marco na história brasileira de modo a assinalar a mudança do jornalismo político-literário para o informativo, "que privilegiava a informação 'objetiva', separada editorial e graficamente do comentário pessoal" (RIBEIRO, 2000, p. 30, grifos da autora). Ao fazer uso de técnicas e padrões específicos, a imprensa buscou se constituir como um espaço de prática da linguagem jornalística, propriamente dita, ao invés da linguagem literária que outrora a caracterizou ${ }^{2}$. Para fazer valer os ideais que marcavam o jornalismo moderno e convencional, valorizou-se a notícia e todo um procedimento técnico que a envolvia.

Toda a mudança ocorrida na imprensa nesse período era resposta ao próprio panorama político, econômico e cultural em que o país se encontrava: democrático, de liberdade, desenvolvimentista e moderno. O processo de urbanização acelerado, as novidades tecnológicas que surgiam, o estilo de vida que modificava os hábitos cotidianos impuseram velocidade aos acontecimentos e conseqüentemente um ritmo acelerado ao jornal para noticiar fatos nacionais e internacionais.

Com a posse do presidente Juscelino Kubitschek em 1956, seguindo um regime político democrático, de liberdade e com a implementação de um plano econômico desenvolvimentista, promoveu-se uma grande modernização nacional o que fez espalhar uma onda de otimismo por todo o território brasileiro. Foi um período que se divulgava a promessa de que o país cresceria e se desenvolveria 50 anos em 5. A economia tornou-se prioridade para o Estado. O projeto, mais conhecido como Plano de Metas, atendia a cinco setores: energia, transporte, alimentos, indústrias de base e educação, bem como o da construção de Brasília para mudança da capital baseada no ideal arquitetônico modernista de Niemeyer e

\footnotetext{
${ }^{2}$ No século XIX e XX, não havia uma prática jornalística porque a imprensa não criara técnicas para a elaboração das informações. Para Pereira (1994), apesar de possuir caráter de empresa jornalística e conjugar princípios dessa natureza, faltava-Ihe uma linguagem jornalística sistematizada como base ao campo do jornalismo. E foi somente na década de 50 que se oportunizou essa sistematização.
} 
Lúcio Costa, que se consolidou como modelo urbanístico pretendido para o país, e do incentivo à importação de indústrias e tecnologias. E para financiar o projeto desenvolvimentista, o País buscou, no mercado estrangeiro, volumosos empréstimos, incluindo acordos com o Fundo Monetário Internacional (FMI).

Nessa época, o país passava por significativas transformações econômicas: expansão da industrialização, avanços tecnológicos que exigiram grandes investimentos de infra-estrutura, migrações internas, a urbanização ganhou ritmo acelerado e a expansão do crédito para que a população pudesse adquirir bens duráveis de consumo. O sistema bancário também iniciava sua expansão. Todas as transformações impuseram novos padrões de consumo que, segundo Mello e Novais $(1998)^{3}$, podiam ser comparados ao consumo dos países desenvolvidos.

Fabricavam-se produtos de siderurgia, energia elétrica, petróleo e derivados, materiais de construção, produtos alimentícios industrializados, têxteis, de confecções, produtos de beleza, de higiene e limpeza pessoal e do lar, produtos farmacêuticos, calçados, bebidas, móveis, eletrodomésticos, eletroeletrônicos, expansão dos meios de comunicação como o rádio e a televisão, da telecomunicação. Além do consumo crescente, mudava-se o sistema de comercialização com a criação do supermercado e do shopping center.

Vivia-se um momento de modernização, quando novos valores surgiam e passavam a influenciar os valores atribuídos às manifestações culturais da época. Tudo que se produzia seguia as mesmas concepções ou normas daquilo que se constituía como moderno que não estava presente apenas nos produtos que eram produzidos e consumidos, mas também nas idéias produzidas e nos pensamentos cujos discursos se constituíam das expressões valorativas da época e de como eram assimiladas, reelaboradas e reacentuadas.

Todo esse processo influiu nas manifestações culturais das diversas esferas da atividade humana, e não poderia ter sido diferente com as produções da esfera jornalística. Para que os jornais acompanhassem os padrões da época, precisaram fazer grandes investimentos para introduzir novas tecnologias, comprar novos equipamentos, rotativas e renovar parques gráficos e todos os recursos provinham

\footnotetext{
${ }^{3}$ Segundo os autores, o sentimento de modernização, sentido por grande parte dos brasileiros, se iniciou em 1950 e se estendeu até 1979 porque a partir de 1980, a impressão de progresso sentida nesses anos anteriores começou a se ruir, uma nova realidade se impôs com a estagnação econômica, superinflação, desemprego, violência, drogas etc. Para Faro (1999, p. 90), a sociedade brasileira viveu "sob o impacto da hipertrofia que o Estado brasileiro havia adquirido após a edição do Ato Institucional no.5, em dezembro de 1968".
} 
tanto dos anúncios comerciais e publicitários dispostos nas páginas dos jornais como dos grandes empréstimos adquiridos com os bancos que, de acordo com Ribeiro (2000), desempenharam importante papel na modernização da imprensa.

Com investimentos, muitos jornais conseguiram ampliar suas atividades, época em que lançaram os suplementos literários. Esse fato aconteceu principalmente com os jornais cariocas que, segundo Abreu (1996) ${ }^{4}$, tinham tradição no jornalismo que utilizava recursos da literatura. A arte e a literatura ganhavam espaços aí reservados, publicados aos sábados ou domingos, os suplementos traziam contos, crônicas, poesia, tratavam das artes plásticas e de outras atividades culturais. Alguns jornais dedicaram espaços aos suplementos femininos que divulgavam assuntos diversos como: cuidados com o lar, receitas culinárias, moda e assuntos relacionados à família. Destinavam-se também à divulgação de livros publicados: romance, contos, poesia, entre outros.

Essas produções, em espaços exclusivos, tinham forte ligação com 0 contexto cultural vivenciado naquele período. Havia muitos movimentos culturais que forjavam uma ruptura com o passado para se constituírem como produções modernas e de vanguarda, fato que acabou influenciando a imprensa a fazer as suas mudanças de modo, então, que pudesse desempenhar seu papel social e também cultural. As produções estavam também ligadas às mudanças que influenciavam os costumes e os comportamentos da época, daí a necessidade de atender à demanda por informações sobre moda, educação, comportamento, lazer, entre outros assuntos.

Precisamos considerar um ponto importante: nesses espaços exclusivos, o grau de padronização era menor, pois o jornal tinha também a liberdade para criar, para trabalhar as matérias sem restrições quanto ao conteúdo temático que se pretendia abordar, ao estilo da linguagem utilizada e à construção composicional do texto ${ }^{5}$, que permitia ao jornal marcar seu diferencial em relação aos demais. Inclusive porque essas matérias eram escritas também por intelectuais que para ele colaboravam.

\footnotetext{
${ }^{4}$ Alzira Alves de Abreu pesquisou os seguintes jornais: Jornal do Commercio, Jornal do Brasil, Diário de Notícias, Correio da Manhã, O Jornal, Diário carioca e A manhã do Rio de Janeiro. Em São Paulo, os jornais O Estado de S. Paulo e Folha da Manhã e em Belo Horizonte, O Estado de Minas.

${ }^{5}$ Apropriamo-nos aqui dos conceitos utilizados por Bakhtin (2003). A linguagem e a forma como ela é construída caracterizam a expressividade de um texto e o jornal como um conjunto de textos tem a sua expressão no tratamento dos temas escolhidos.
} 
Ainda que as mudanças caminhassem para a valorização dos princípios da objetividade da informação e, conseqüentemente, para uma produção jornalística que pudesse representar esses princípios, observamos que as produções artísticas e literárias continuaram a fazer parte do jornal mesmo em páginas ou cadernos específicos e sem utilizar as técnicas e os padrões jornalísticos convencionais ${ }^{6}$. De qualquer maneira a ampliação desses espaços significava também a possibilidade de ampliação da publicidade de modo a atender o público determinado desses cadernos.

Nesse sentido, podemos trazer a própria experiência do Jornal do Brasil ${ }^{7}$. Em 1956, iniciaram-se as primeiras mudanças para a implantação de uma grande reforma. Nesta primeira fase, foram contratados Odylo Costa Filho para chefiar a redação e promover a reforma e os jornalistas: Ferreira Gullar, Jânio de Freitas, Carlos Lemos, José Ramos Tinhorão, entre outros. Depois, em 1957, contrataram Amílcar de Castro para dirigir a diagramação do jornal. Como escultor, desenhista, gravador e diagramador que sempre dedicou seu trabalho à formalização da arte construtiva. Amílcar fez as primeiras mudanças que incluíram a criação do Suplemento Dominical e do Caderno B.

\subsection{O Suplemento Dominical do Jornal do Brasil - SDJB}

\footnotetext{
${ }^{6}$ Este fenômeno pode ser relacionado às próprias limitações da linguagem jornalística em comunicar o real. Segundo Faro (1999), o ritual noticioso executado pela imprensa não alcança [e não alcançava] a amplitude e a complexidade da própria realidade. Podemos dizer que, de uma certa forma, os textos possuem limites para expressá-la pois cada um deles representa determinados pontos de vista acerca dos acontecimentos do cotidiano e as limitações são superadas à medida que compreendemos a interação dialógica entre os textos do jornal e a vida cotidiana da qual participam. As produções artísticas e literárias, presentes no jornal, eram respostas à efervescência cultural da época e não seria possível retratar a realidade quanto à complexidade dos acontecimentos político, econômico e cultural sem recorrer à diversidade de formas da comunicação existentes. No capítulo três deste trabalho, trataremos sobre a interação dialógica baseada na noção de enunciado concreto de M. Bakhtin.

${ }^{7}$ Desde 1921, o Jornal do Brasil, na fase em que era dirigido pelo Conde Pereira Carneiro, se caracterizou como um veículo de anúncios classificados. Segundo Lessa (2005), dedicava cerca de $80 \%$ do espaço aos anúncios de pequenos anunciantes. Durante um longo período, o jornal se destacou nesse segmento, mas não ganhou importância como órgão noticioso. Foi somente na década de 50, mais exatamente em 1954, com a morte do Conde e com a posse de sua esposa, a Condessa Maurina Dunshee Abranches Pereira Carneiro e de seu genro, Manuel Francisco do Nascimento Brito, na direção do jornal, que teve início o processo de reorientação editorial.
} 
Criado por Reynaldo Jardim ${ }^{8}$, o Suplemento Dominical - SDJB era um caderno de variedades que durante os cinco anos de existência foi um espaço dedicado tanto para cronistas como para cineastas, poetas, novos autores. Esteve sempre ligado aos movimentos culturais de vanguarda da época: das artes plásticas, da dança, do cinema, do teatro, da música.

Esses profissionais não eram jornalistas de formação, mas intelectuais como o próprio Jardim, que a seu convite compuseram o grupo de trabalho. Segundo Gullar (2005), que também era um dos intelectuais do grupo e atuava como crítico de arte, decidiu-se, em 1959, fazer um número especial do Suplemento para o lançamento do Movimento Neoconcreto e a apresentação do manifesto ${ }^{9}$. Tiveram, então, a idéia de chamar Amílcar de Castro para criar a paginação daquela edição:

ele fez a paginação que se tornou famosa. A primeira página do "Suplemento Dominical do Jornal do Brasil" lançava o manifesto neoconcreto e se tornou um exemplo de paginação moderna inovadora, criada por Amílcar. A partir daí, o Reynaldo Jardim [...] passou a fazer ele próprio a paginação do "Suplemento", seguindo a linha criada e indicada pelo Amílcar nesse número especial. (GULLAR, 2005, p.51)

A paginação foi considerada moderna porque Amílcar de Castro conseguiu trazer o artístico para o jornal. A partir de sua experiência como escultor e participante do movimento concretista ${ }^{10}$, todo o espaço da página do Suplemento passou a comunicar a arte concreta pela própria expressão do espaço: o branco da página dava sentido ao preto caracterizado pelas marcas tipográficas e vice-versa.

\footnotetext{
${ }^{8}$ Reynaldo Jardim, em entrevista a Aguilera (2005), comenta que o SDJB surgiu primeiramente na Rádio Jornal do Brasil. Ele criara o programa de crítica e comentários chamado Suplemento Dominical do Jornal do Brasil que era um suplemento virtual, pois o JB não editava nada semelhante. Convidado a fazer uma coluna sobre literatura aos domingos, passou a escrever a coluna, intitulada, Literatura Contemporânea que foi a semente do SDJB.

${ }^{9}$ Escrito por Ferreira Gullar, o manifesto do Movimento buscava impor a discussão acerca do concretismo. Segundo Sant'Anna (2004), tratava-se de uma ruptura no interior da abstração geométrica de modo a abandonar o rigor formal e a radicalidade das formas geométricas puras para seguir-se como arte orientada para o público na relação deste com a obra e poder ser designada como arte brasileira contemporânea. O movimento neoconcreto se diluiu em 1963 depois que a arte passou a ser orientada por outros parâmetros.

${ }^{10}$ Os projetos gráficos de Amílcar de Castro situam-se na categoria da Gráfica Construtiva que, segundo Fabbrini (2005), foi difundida por diversos artistas nos anos 20 e 30 na Alemanha em pôsteres, anúncios, catálogos de exposições, diagramações de jornais, revistas e livros, embalagens de produtos. Considerado um design novo e moderno.
} 
Como os fios que separavam as colunas foram retirados, não só as palavras ganharam destaque como também os espaços em branco.

\begin{abstract}
Cada página do "Suplemento Dominical" passou, então, a ser composta em função do contraste bipolar [...] as áreas não impressas ou o branco do papel foram considerados elementos da composição, tanto quanto as áreas impressas constituídas de letras, traços ou ilustrações; ou, mais do que isso: os espaços foram ampliados, estendidos como nunca na imprensa escrita, pois, para Amílcar, o texto cerrado, sem o vácuo, o vazio, ou o branco, que permitem respirar, sufocam o leitor. (FABBRINI, 2005, p.23-24, grifos do autor)
\end{abstract}

As informações do autor, acima colocadas, vêm confirmar que a reforma gráfica foi inovadora, ousada porque não se resumiu a uma beleza vazia, isto é, o branco não era o vazio, mas um espaço expressivo. Assim, a comunicação acontecia pela interação de diferentes linguagens: a plástica e a jornalística e pela forma composicional dos textos, isto é, por sua construção semiótica estabelecida na interação tanto das imagens dialogando com as palavras, a escrita dialogando com a tipografia e os espaços em branco da página quanto do contexto cultural da época: as diversas atividades de vanguarda produzidas e que davam o tom às produções culturais daquele momento como os poemas concretos e neoconcretos. A expressividade do SDJB, que se construiu na dinâmica do diálogo, transformou-o num veículo de cultura importante, senão o mais importante do país.

Para Gullar (2006), o suplemento fora o mais revolucionário e polêmico da imprensa brasileira, considerado o porta-voz da poesia concreta e do movimento neoconcreto que mudou o curso da arte brasileira por suas idéias e obras. O êxito do SDJB possibilitou que o Jornal do Brasil tivesse prestígio e expressão e deixasse de ser visto apenas como um jornal de classificados.

O momento era propício para a criação, para a inovação e para a experimentação ${ }^{11}$ que possibilitava que o artístico pudesse ocupar as páginas do jornal. O JB não só inovou como compartilhou e até, se possível dizer, contribuiu como coadjuvante desse movimento que trazia o novo em suas produções. 0 próprio suplemento representou o fazer artístico que surgia e se estabelecia naquele

\footnotetext{
${ }^{11}$ Segundo Jardim (2005), a criação acontecia livremente, sem o uso de cartilha e preconceitos.
} 
momento, isto é, a atividade jornalística, dialogando com o contexto social e cultural externo do qual a atividade artística se formava e passava a compor o texto jornalístico. Era um híbrido de diferentes linguagens e códigos que em interação dialógica recodificava o sentido do novo, tanto da prática do jornal quanto da prática da arte. Características que marcaram o Suplemento durante todo o período de sua existência, até 1961 quando deixou de existir.

Diante do prestígio alcançado ${ }^{12}$ a partir do êxito do Suplemento, a proprietária do jornal, Condessa Pereira Carneiro, decidiu promover uma reforma geral para modernizar o JB.

Começava, em 1959, a segunda fase das mudanças, com Jânio de Freitas à frente da chefia de redação com a tarefa de acelerar o processo da reforma:

O Amílcar foi o responsável, coadjuvado pelo Jânio de Freitas, pela formatação do jornal em sua parte jornalística propriamente dita: 0 essencial. [...] O SDJB, "Caderno B" e outros produtos, foram mentados, editados, diagramados e dirigidos pessoalmente por mim. (JARDIM, 2006, p.64.)

A reforma então ganhou força, mesmo diante das resistências dos jornalistas, dos profissionais da oficina gráfica e da própria direção do jornal ${ }^{13}$. Dentre as muitas mudanças ocorridas, uma marcante, apresentada em 2 de junho de 1959, a do layout assimétrico com o surgimento do "L" à primeira página em que alguns classificados ficaram dispostos numa coluna esquerda e no rodapé. Essa forma ultrapassou a década de 60 e continuou sendo apresentada na década de 70 . Os demais classificados ocuparam um caderno separado, o Caderno C. Em 1960, Reynaldo Jardim lançava um caderno cultural diário, mais exatamente, o Caderno B

\footnotetext{
${ }^{12}$ Vale reforçar que as experimentações tinham a aprovação da Condessa embasada nas manifestações do público, de profissionais e amigos. De acordo com Gullar (2005), isso ocorria a cada inovação feita, até mesmo quanto à inserção de uma fotografia na primeira página do jornal.

${ }^{13}$ As resistências se davam principalmente quanto ao uso do papel. Para Nascimento Brito, os espaços em branco eram considerados um desperdício, inclusive porque as empresas jornalísticas tinham dificuldades para comprar o papel de imprensa. A década de 50 foi marcada pelos problemas de escassez uma vez que a produção nacional de papel de jornal não atendia à demanda interna do país, obrigando a importá-lo. Ainda assim havia cotas de importação de papel estrangeiro. Mais tarde na década de 60 , com os problemas econômicos e com as altas taxas de inflação, a crise só piorou. Ribeiro (2000), em sua pesquisa sobre os jornais cariocas descreve em detalhes sobre a crise do papel bem como no trabalho desenvolvido por Dines (1986).
} 
que segundo ele surgiu "na brecha, entre a parte noticiosa e a parte dos anúncios [...]" (JARDIM, 2005, p.65).

\subsection{O Caderno B}

$\mathrm{Na}$ quinta-feira, do dia 15 de setembro de 1960, surgia o Caderno B que abordava a cultura nacional e internacional com uma variedade de textos diferenciados. Não se tratava de um caderno que incluía apenas textos artísticoliterários, mas incluía também textos que informavam sobre a arte, a literatura, a música e o teatro, sobre comportamento, sobre o cotidiano, principalmente o do Rio de Janeiro. Escrito por intelectuais e jornalistas, o Caderno B se constituiu pelo que atualmente denominamos e conhecemos como caderno cultural. Para Gullar (2006), este se tornou um padrão para os jornais brasileiros, pois trazia a novidade de reunir todas as seções e matérias relacionadas a artes e espetáculos num único caderno e, hoje, segundo ele, não há um jornal que não tenha esse tipo de caderno. Para Piza (2003, p.37), ele se tornou "o precursor do moderno jornalismo cultural brasileiro".

Em leitura de sua primeira edição, os destaques da primeira página do caderno, traziam as novidades sobre a extinção do Suplemento Feminino, tabloid que saía de terça a sexta-feira e que se incorporou ao novo caderno, esclarecendo às leitoras que elas ganhavam oito páginas com informações mais amplas e novas colunas $^{14}$. A Revistinha, encarte infantil, deixava a edição de domingo e se incluía no caderno $\mathrm{B}$ aos sábados. Ainda nessa página, era anunciada uma promoção ao ouvinte da Rádio Jornal do Brasil. E uma foto da atriz internacional de cinema, Romy Schneider, e um molde de costura de Gil Brandão, estilista famoso que propagou no JB a popularização do uso de moldes com estilo que eram apresentados à página 5 . Vale lembrar que a indústria têxtil se desenvolvia para ganhar o mercado nacional e era costume as mães costurarem para a família. Com o passar do tempo, a moda se industrializou e a produção de roupas passou a ser feita em massa.

\footnotetext{
${ }^{14}$ A criação deste caderno diário era, de fato, uma grande inovação, pois alguns jornais costumavam apenas dedicar algumas páginas exclusivamente femininas como, por exemplo, ocorria no jornal Diário da Noite. Outros dedicavam o feminino e o literário a suplementos especiais que circulavam apenas nos fins de semana.
} 
A página 2 tratava da literatura, a coluna Vida Literária, escrita pelo jornalista Mauritônio Meira, referia-se aos prêmios literários; na de artes visuais, Ferreira Gullar anunciava e comentava as exposições dos museus de arte nacionais e internacionais. O crítico Renzo Massarani escrevia em sua coluna sobre música e a de Notas Religiosas era escrita por Antônio Carlos Villaça, jornalista, tradutor e reconhecido memorialista do Brasil. Havia as informações sobre televisão, com a programação da TV Tupi, a TV Continental e a TV Rio, a programação da Rádio Jornal do Brasil, com as promoções e as músicas mais tocadas e a coluna social, Notas e Comentários, de Souza Brasil.

$\mathrm{Na}$ página 3, encontravam-se as tiras e as histórias em quadrinhos, bem como aulas de um curso de inglês (lição 19) e uma seção sobre decoração em que o leitor encaminhava carta para a redação do SF (Suplemento Feminino) para receber orientações de como decorar sua casa. Os quadrinhos também estavam presentes na página 4, dividindo o espaço com receitas culinárias, dicas de comportamento e uma letra de música l'Il never fall in love again de Johnnie Ray, na seção: O sucesso de hoje ${ }^{15}$.

A página 6 destinava-se ao roteiro dos espetáculos culturais, ao cinema com a presença marcante de filmes europeus e alguns poucos americanos e ao teatro com destaques ao teatro de Revista e ao de Comédia. Os acontecimentos sobre o turfe e sobre os esportes ocupavam as páginas 7 e 8 , respectivamente. A publicidade era pouca, nessa edição apenas três e poucas fotos ilustrativas.

Rito (1990, p.8), em texto comemorativo aos 30 anos do caderno, comentava que o primeiro número era ainda um caderno indeciso entre o reproduzir o modelo de um suplemento feminino ou o assumir uma posição de vanguarda, mas com o passar do tempo passou a funcionar "como uma espécie de antena da cultura e do comportamento do Rio de Janeiro", tornando-se célebre no Brasil.

De fato, o Caderno $B$ em seu primeiro número não foi muito diferente do Suplemento Feminino, pois muitas colunas ali apresentadas foram introduzidas ao novo caderno. Inclusive, em texto de apresentação desse número frisava: "Leitoras do SF ganham mais espaço e informações" (JORNAL DO BRASIL, 1960, p.1).

\footnotetext{
${ }^{15}$ Os textos em inglês reproduzidos nessas páginas demonstravam a cultura estrangeira já permeada na cultura nacional. De acordo com Mello e Novais (2002), a partir do anos 50, havia um grande fascínio em copiar o padrão de consumo e o modelo de vida americano, mais conhecido como American Way of Life. Daí poder compreender porque os movimentos culturais do país se manifestavam em busca de uma identidade nacional.
} 
Também não possuía o mesmo caráter vanguardista do SDJB, pois não mantinha vínculo com nenhum movimento de vanguarda, apenas, nesse momento, se caracterizava como inovador pela reunião das matérias sobre cultura estarem em um único caderno e, principalmente, por incorporar as mesmas mudanças gráficas e de diagramação dos demais cadernos e do próprio SDJB. Por este ponto, representava o caráter inovador:

\begin{abstract}
A experiência desse segundo caderno consolida transformações gráficas conquistadas durante a reforma, e, ainda mais, valoriza o conteúdo das colunas infringindo a pretensa objetividade pregada para as notícias engessadas pela forma norte-americana do lide e sub-lide e pelas regras dos manuais de redação.

O Caderno $B$ transmite, neste sentido, o mesmo espírito do novo presente na reforma da imprensa brasileira do final da década de 1950. E não é por inexistir qualquer vínculo direto com as artes novas que seria menos vanguardista do que o Suplemento Dominical do Jornal do Brasil. Ambos procuraram exercer no meio jornalístico um papel pioneiro, desenvolvendo técnicas, idéias e conceitos novos, tidos como avançados em sua época. Embora a maioria dos jornais circulassem com segundos cadernos, é justamente essa característica que faz do $B$ o pioneiro dentre os contemporâneos. (LIMA, 2006, p.74)
\end{abstract}

Com o passar do tempo, o caderno ganhou profundidade no trato dos temas culturais, com mais colunas que eram assinadas por muitos colaboradores bem como artigos sobre cinema, teatro e espetáculos musicais. Além de informação, o conteúdo ganhou tom de crítica, de debate. Aos poucos foi perdendo a característica herdada do suplemento feminino e passou a adquirir um perfil próprio, de um caderno de cultura engajado aos acontecimentos culturais da época sem deixar de estabelecer relação com a política e a economia do país pelo modo como tecia o cotidiano do Rio de Janeiro em textos diversificados ${ }^{16}$ que o diferenciaram dos demais cadernos culturais de outros jornais. É o que podemos observar no final da década de 60, período em que o caderno consolidou esse perfil. O tom dado ao conteúdo dos textos, que compuseram o caderno destas edições, já não era o de apenas informar os acontecimentos culturais, mas também o de formalizar opiniões sobre eles.

A formalização da crítica ganhou força pela inserção das colunas assinadas:

\footnotetext{
${ }^{16}$ Entenda-se por diversificados os mais variados textos. O caderno se constituía de colunas sociais, crônicas, contos, artigos, histórias em quadrinhos, notas, entre outros.
} 
Assinar uma coluna era ter um espaço nobre na imprensa. Significava adquirir prestígio e notoriedade perante o público e reconhecimento por parte dos seus pares. [...]

Ter uma coluna significa, além disso, poder fugir da rigidez dos textos informativos, poder desenvolver o estilo pessoal com uma liberdade que não se tinha no noticiário. O formato da crônica - gênero em geral adotado nas colunas - era bastante solto. O escritor fazia comentários livres sobre diferentes tópicos do noticiário da semana. (RIBEIRO, 2000, p.215).

Salientamos que a rigidez não era uma imposição feita às colunas ${ }^{17}$ uma vez que estas eram escritas principalmente por colaboradores e não por profissionais contratados pelo jornal ${ }^{18}$. Coube, então, ao caderno cultural toda a liberdade de criação em estilo próprio, sem a padronização instituída pelos princípios jornalísticos da objetividade que os jornalistas seguiam para a produção, por exemplo, das notícias escritas para o primeiro caderno, o de atualidades. Ao abrir espaço para escritores e para intelectuais que atuavam no cinema, no teatro e nas artes plásticas permitiu-se ampliar a captação da realidade, isto é, da vida cotidiana do Rio de Janeiro em textos ${ }^{19}$ produzidos para o jornal e que colaboraram na construção do cenário desse cotidiano sem excluí-lo dos fatos políticos e econômicos do país.

Reforçarmos também que nesse período, o Rio deixara de ser a capital do país e tornara-se o Estado da Guanabara. Segundo Lima (2006), a política de Carlos Lacerda, então governador, intensificou o incentivo à inovação nas artes para que a cidade mantivesse um status de capital cultural. Para isso foram criados projetos que estabeleceram práticas e estratégias políticas de modo a garantir a realização e o reconhecimento da cidade e de sua capitabilidade cultural. Os produtores culturais tanto apoiaram os projetos como participaram ativamente. Era época em que os intelectuais cariocas possuíam autonomia integral para exercer crítica social e oposição política. Para a autora, a manutenção do status de capital cultural do Rio de Janeiro pode ter uma relação direta com a criação do segundo caderno na imprensa, incluindo aí o Caderno B do Jornal do Brasil.

\footnotetext{
${ }^{17}$ A coluna está sendo considerada como toda a seção fixa, publicada com regularidade e sempre na mesma página do jornal ou revista (MELO,1994).

${ }^{18}$ Havia profissionais de imprensa, mas não havia obrigatoriedade na contratação de jornalistas.

${ }^{19}$ Referimo-nos textos a toda produção do caderno, sem aqui nos preocuparmos em nomear seus gêneros.
} 
As mudanças ocorridas com o Caderno B estavam ligadas também às mudanças pelas quais ainda passava o próprio jornal. Saía Jânio de Freitas em 1961 e chegava Alberto Dines em 1962 no cargo de novo editor-chefe que ocupou até $1973 .^{20}$

Nesta fase, em que ocorreu a consolidação da reformulação do jornal, Dines introduziu algumas mudanças importantes: como a do horário para planejamento do jornal que passou a ser feito logo após o almoço e não mais no final da tarde como acontecia anteriormente, da implantação das reuniões de pauta e da criação das editorias: a do esporte, da polícia, do turfe, a da fotografia que antes era um departamento controlado por um gerente e com a editoria, o editor passou a selecionar as fotos que considerava as melhores para a primeira página. ${ }^{21} \mathrm{~A}$ editoria do Caderno B ficou a cargo do Nonato Masson até 1964, quando deixou de ser editor e em seu lugar assumiu Paulo Afonso Grisolli no período de 64 a 1972. A partir de 1967, mais exatamente, no dia 19 de agosto, o caderno passou a circular no sábado, com a estréia da coluna de Clarice Lispector. A equipe de Dines desenvolveu um novo projeto para o jornal que incluía a criação do Caderno $B$ aos sábados e domingos, pois esta seção cultural saía apenas de terça a sexta.

Nesse momento, o caderno ganhou densidade, as colunas tratavam com profundidade os temas referentes aos acontecimentos culturais. Havia uma preocupação não apenas com a informação como também com a formação do leitor. As matérias reportavam sobre os movimentos nacionais e internacionais do cinema, do teatro, da literatura e da música que ocupavam quatro páginas do caderno, as demais eram dedicadas às colunas mais breves e as de divulgação dos espetáculos e shows, cursos e exposições que completavam as oito páginas do caderno.

Clarice Lispector escrevia semanalmente sua coluna fixa à página dois e dividia o espaço com as colunas de Bárbara Heliodora, de José Paulo M. da Fonseca, de Wilson Cunha, de José Carlos Oliveira, de Yan Michalski, de Irineu Garcia, de Danusia Barbosa, de Walmir Ayala, de Zózimo, entre outros.

\footnotetext{
20 "Assumimos o cargo de editor-chefe no dia 6 de janeiro de 1962, uma segunda-feira. Dias antes, o diretor do jornal, Dr. M. F. do Nascimento Brito, dissera-nos: 'Quero, na terça-feira, um jornal completamente diferente'. Ao que respondemos: ' $O J B$ será um jornal diferente dentro de poucos anos. Agora é impossível.' Na primeira edição sob nossa responsabilidade a única alteração foi o fio de paginação sob o logotipo para prendê-lo ao alto da primeira página. Mas 11 anos e 11 meses depois, seguramente, tínhamos um jornal bem diferente." (DINES, 1986, p.51)

${ }^{21}$ Estas informações foram extraídas da entrevista que Dines concede aos entrevistadores e pesquisadores Costa e Devalle (2002) e que se encontra no site do Observatório da Imprensa.
} 
Para Nava (2006), além dessas mudanças, outra se fez importante como a implementação do Departamento de Pesquisa e Documentação. O DPD foi idealizado e criado por Dines para dar apoio à redação, aos jornalistas e repórteres em geral de modo a fornecer antecedentes históricos, mapas e biografias para complementação de informações.

\subsection{A produção cultural: manifestações e rupturas}

As mudanças para o novo se fizeram presentes também nas produções de outras esferas. Entre os anos 50 e 60, muitos trabalhos surgiram e tornaram-se expoentes: nas artes plásticas com o movimento construtivista neoconcreto; na música com o movimento da bossa nova; na dramaturgia com o Teatro Oficina e o Teatro de Arena; na cinematografia com o Cinema Novo.

O cinema iniciava uma nova fase. A partir dos debates e das reflexões que ocorreram em dois congressos nacionais sobre o Cinema Brasileiro (1952 no Rio de Janeiro e 1953 em São Paulo), os cineastas discutiram a necessidade de propor novos ideais à produção nacional de modo que tratasse da realidade do país com temas relacionados ao cotidiano do povo brasileiro. Desejavam uma produção que retratasse a realidade nacional, ideal que rompia com os modelos anteriores. Não havia interesse em reproduzir as produções cinematográficas dos estúdios criados na década de 40 e muito menos seguir o modelo americano de Hollywood, mas o de produzir filmes que pudessem dar enfoque à temática social do Brasil. Segundo Tonetto (2006, p.57), o neo-realismo do cinema italiano influenciou o Cinema Novo porque "continha a fórmula adequada para o momento, não só pelo slogan do nacional, mas também pela facilidade na produção", que se baseava na técnica documental, na produção sem muitos efeitos e na temática sobre a realidade social.

O mesmo ocorria com a dramaturgia que também teve seus movimentos de vanguarda com o Teatro Oficina e o de Arena, ambos nascidos em São Paulo. O teatro brasileiro, entre 1950 e 1960, estava preocupado em criar uma identidade própria a partir de uma dramaturgia e repertório nacionais. Foi marcado pelo aperfeiçoamento técnico, pela busca da formação de uma platéia consciente dos problemas da sociedade, pela especialização de atores, figurinistas, cenógrafos e 
diretores. Em 1956, surgia o Teatro de Arena, que de acordo com Garcia (2004, p.129), buscava "criar uma identidade própria para o primeiro teatro em formato de arena da América do Sul, ou seja, uma identidade fundada na dramaturgia e na arte cênica brasileiras". O Arena propunha-se ser mais democrático de modo que pudesse atingir as massas populares rompendo, assim, com o modelo empresarial de alguns outros teatros.

Já o Teatro Oficina, fundado em 1958, surgiu com peças escritas e encenadas pelos próprios componentes. As peças eram apresentadas em pequenos espaços e até em residências. Seu objetivo não foi o de transformar a cena teatral no país e nem assumir identidade nacionalista, mas o de assumir "o caminho da profissionalização". (PATRIOTA, 2003, p.139). Só mais tarde, no período pós-64 que passou a estabelecer diálogo com a conjuntura da realidade brasileira, influenciando algumas manifestações artísticas desse período.

$\mathrm{Na}$ música, despontava a bossa nova e trazia com ela uma batida que permitia produzir "um tipo de ritmo em que cabiam todas as liberdades que se quisesse tomar". Com aquela batida, simplificava-se o ritmo do samba e dava espaço para harmonias ultramodernas. (CASTRO, 2004, p. 167). Eram os anos 57, 58 e 59. Para Naves (2000), o movimento bossa nova se caracterizou como um tipo de experimentação musical, provocando um rompimento com as tradições anteriores da música popular no Brasil.

A ruptura foi a marca da modernização. Para que as produções culturais ganhassem a denominação de moderno, do novo, precisavam mostrar uma descontinuidade com as produções anteriores, no entanto, essa descontinuidade só poderia ser compreendida e valorizada como ruptura na dinâmica dialógica estabelecida com as outras produções, com aquelas anteriores, as que não eram novas, mas consideradas já ultrapassadas. Nessa dinâmica, o moderno só se revelou como elemento novo em contato com outro sentido, pois de acordo com Bakhtin (2003, p. 382), "um sentido atual não pertence a um (só) sentido mas tãosomente a dois sentidos que se encontraram e se contactaram. Não pode haver 'um sentido em si' - ele só existe para outro sentido [...]"

Nas artes plásticas, movimentos surgiram em prol dessa descontinuidade, como o Concretismo: movimento que reuniu muitos $\operatorname{artistas}^{22}$ que acreditavam na

\footnotetext{
${ }^{22}$ Como Lygia Pape com o balé neoconcreto, o poeta Reynaldo Jardim, os artistas plásticos Lygia Clark, Helio Oiticica e seu irmão César Oiticica, Franz Weissman, Aluísio Carvão, Décio Vieira, Ivan
} 
arte orientada para o público e na relação deste com a obra. O enfoque à inovação permitia designá-la como arte brasileira contemporânea.

\subsubsection{Manifestações: antes do Golpe Militar}

Ao fazermos um paralelo com a política nacional, 1961 foi marcado por muitas mudanças: Juscelino Kubitschek terminara seu mandato e para seu lugar, foram eleitos Jânio Quadros para presidente e João Goulart como vice. Em menos de sete meses de governo, o presidente Quadros renunciou. Diante da conturbada situação e numa tentativa de quase um golpe, Goulart conseguiu tomar posse ${ }^{23}$ e governar até 1964.

O governo Goulart foi marcado por muitos problemas herdados dos dois governos anteriores. Problemas como o progressivo endividamento externo decorrente do projeto de modernização do país estabelecido no governo do presidente Kubitschek e outros relacionados à fracassada administração de Jânio Quadros que após sua renúncia, destinou o país a uma profunda crise institucional:

\footnotetext{
um novo contexto político-social emergiu no país. Este novo quadro caracterizou-se por uma intensa crise econômico-financeira, freqüentes crises político-institucionais, extensa mobilização política das classes populares, ampliação e fortalecimento do movimento operário e dos trabalhadores do campo, crise do sistema partidário e acirramento da luta ideológica de classes. (TOLEDO, 1997, p. 9)
}

A crise se agravou com a elevação das taxas inflacionárias ainda no governo JK bem como o descompasso entre o setor industrial e agrícola, este não conseguiu atender a demanda de alimentos, a população se urbanizou e adquiriu poder de compra, no entanto, o período foi marcado pelo baixo crescimento da produção

Serpa entre outros que faziam da experimentação uma forma inovadora de fazer arte e que ainda hoje em exposições dos trabalhos desses artistas destacam-se a ousadia de suas obras como é o caso da Mostra Arte e Ousadia - o Brasil na Coleção Sattamini do Masp que, em 24 de agosto de 2007 , reuniu as obras de muitos artistas dessa época para comemorar os 50 anos de arte brasileira.

${ }^{23}$ A renúncia de Jânio Quadros levou a uma crise que foi contornada no momento em que o Congresso decidiu votar a Emenda Constitucional n. 4 a fim de que se alterasse a Constituição em vigor para a introdução do regime parlamentarista no Brasil. João Goulart foi empossado sob esse regime que vigorou até 1963, quando ocorreu um plebiscito no país que decidiu a mudança para o presidencialista. (SANFELICE, 1986) 
agrícola, ocasionando maior procura e menor oferta. Foi uma época que, segundo Toledo (1997, p.24), as crises de abastecimento se acentuaram provocando "inquietações sociais e movimentos reivindicatórios de grande extensão nos campos e nas cidades".

As classes trabalhadoras urbana e rural, a estudantil, a dos soldados manifestavam-se de um lado e de outro, os empresários, os militares, a Igreja. E diante das inquietações e reivindicações, o governo Goulart partiu para a proposição das Reformas de Base que acabaram não acontecendo.

O final dos anos 60 foi marcado por um ideário político em que o povo lutava por melhores condições de vida, exigia que fosse feita a quebra do monopólio da terra pela reforma agrária, o combate à miséria, o aumento dos salários, a criação de uma escola pública para todos, ampliação dos direitos sociais etc. A politização contagiou também a produção cultural. Artistas, escritores e intelectuais passaram a retratar as tensões vividas nesse período. Havia ainda incentivo à mudança, ao novo, mas sempre com o tom da crítica e da polêmica. A cultura florescia, crescia um forte movimento de levar cultura ao povo.

[...] tudo se foi politizando, tudo se foi contestando, por gente que se empenhava em criar novas formas de cultura e mesmo de convivência. Falava-se muito, discutia-se muito, tudo estava em xeque. Repetia-se ser preciso derrubar as 'estruturas arcaicas'. Eram poetas e romancistas, dramaturgos, artistas plásticos, músicos, cantores, atores, cineastas, psicanalistas, críticos, estudantes, professores: não todos, e certamente uma elite, de novos e não tão novos, procurando em conjunto criar o novo. (GALVÃO, 1994, p.187)

A efervescência político-cultural marcou a radicalização que se apresentava nas propostas de conscientização popular e renovação da linguagem estética. Os filmes do Cinema Novo se voltavam ao cotidiano e à mitologia do nordeste brasileiro com os trabalhadores rurais e as misérias da região, bem como a marginalização econômica.

Era uma época de mudanças também para a Bossa Nova. Numa tendência nacionalista, acabou se direcionando a duas tendências: a formalista que segundo Aguiar (1994) se transformou em produto exportável participando dos festivais de Jazz nos EUA e a nacionalista de caráter participativo que se engajava aos debates 
nacionais que surgiam nos meios culturais. A marca instituída dessa vertente era a canção de protesto ${ }^{24}$ que se identificava com os problemas sociais do país como a fome, a desigualdade, a miséria urbana e rural.

Mas, depois, veio o golpe militar em 31 de março de 1964, e toda a produção cultural sofreu com a repressão militar e a instauração da censura.

\subsubsection{Crises e rupturas: o pós-1964 e o Al-5}

Uma nova ruptura, não mais às velhas formas, mas àquelas impostas pelo golpe de 64, fez encerrar todo o otimismo que alimentava as produções culturais. Essas atividades sofreram com a censura instaurada pelo regime militar e o que se assistiu foi "um assombroso renascimento delas, ainda mais radicalizado" (GALVÃO, 1994, p.191).

Mas a censura introduziu muitas incertezas no cotidiano para todos aqueles que estavam envolvidos com teatro, cinema, música e literatura porque as ações eram arbitrárias. Segundo Almeida e Weis (1998, p.342), "não se vetava apenas o que fosse manifestamente indesejável [...] Mas se vetava tudo aquilo que aos olhos dos militares e de seus aliados civis parecia atentar contra os valores da 'civilização cristã ocidental'".

Nesse momento, surgiram movimentos culturais que utilizavam a crítica como o foco de suas manifestações. A música fez-se em oposição à ditadura, para citar um exemplo, em dezembro de 1964, estreava, no Rio de Janeiro, num shopping inacabado de Copacabana, o show "Opinião" que misturava samba, melodias da bossa nova, jazz, baladas nordestinas e comentários políticos. De acordo com Gaspari (2002), Opinião rodou o Brasil e durante alguns anos foi considerado paradigma da militância cultural oposicionista.

Depois, ainda segundo o autor, em abril de 1965, quando o show saíra de cartaz, estreava a peça "Liberdade, liberdade", por fazer uma colagem de textos antiditatoriais sofreu agressões verbais de provocadores e ameaças telefônicas.

\footnotetext{
${ }^{24}$ Segundo o autor citado, a música de protesto se caracterizou como um movimento de estudantes universitários, intelectuais e artistas da classe média.
} 
Mesmo diante das proibições e perseguições, fez-se um grande esforço na tentativa de resistir e não sucumbir à censura. O teatro acabou ocupando um espaço de significativa importância na sociedade brasileira, e apesar do rigor da censura, conseguiu produzir uma geração talentosa que construiu uma etapa de renovação na dramaturgia. Com espetáculos radicais, provocantes, de forte impacto visual, diretores e cenógrafos propuseram maneiras novas de trabalhar o espaço cênico.

Mas, após o decreto do Ato Institucional n. ${ }^{\circ}$, em dezembro de 1968, o teatro fora escolhido como sendo um dos inimigos prioritários do regime militar e, segundo Michalski ${ }^{25}$ (1994, p.113), "foi submetido a uma censura e outras formas de repressão sem precedentes na história do país", o que fez com que muitas obras não chegassem aos palcos. Aquelas que chegavam sofriam algum corte, segundo o crítico, elas eram mutiladas e outras tantas nem chegaram a ser escritas.

O mesmo aconteceu com a música, o regime ditatorial concentrou-se em vigiar e controlar os artistas e os eventos ligados à Música Popular Brasileira (MPB), principalmente a vertente declaradamente crítica ao regime militar. ${ }^{26}$ Quanto aos eventos musicais, as preocupações estavam relacionadas à capacidade de aglutinação das pessoas, fato que incomodava os agentes da censura porque consideravam que a música desempenhava o papel de "propaganda subversiva" e "guerra psicológica"(NAPOLITANO, 2004, p.108).

O regime ditatorial impôs a repressão não apenas à música e ao teatro que aqui citamos, mas a todas as produções culturais que eram consideradas suspeitas, isto é, subversivas pelos agentes de repressão. A vigilância dava-se aos espaços sociais considerados suspeitos, a qualquer atitude qualificada como subversiva, fosse ela de ordem política, ideológica ou comportamental.

\footnotetext{
${ }^{25}$ Yan Michalski, dramaturgo e crítico, assinava a coluna de teatro do Caderno B no período de 1963 a 1982. Foi considerado um dos grandes críticos cariocas.

${ }^{26}$ Segundo Walnice Nogueira Galvão, citada por Aguiar (1994, p.148),nessa época, havia três linhas dentro da MPB, "duas descompromissadas: o intimismo sentimental (música romântica) e a explosão da ingenuidade adolescente (a jovem guarda). Na terceira vertente, os artistas de formação universitária, que levavam consigo um projeto informativo e participante, tendo no escopo a denúncia das desigualdades sociais [...]"
} 


\section{Capítulo 2 - Clarice Lispector na imprensa: trajetória das revistas ao Caderno B}

Clarice Lispector, antes de escrever para o Caderno B do Jornal do Brasil, já havia trabalhado para a imprensa. Segundo Gotlib (1995), por volta de 1940, ela fora redatora da Agência Nacional que, à época, era um órgão oficial de informação do Brasil, criado por Getúlio Vargas em pleno Estado Novo, e se subordinava ao Ministério da Justiça e Negócio que depois de algum tempo o transformou no Departamento de Imprensa e Propaganda (DIP). Possuía as funções de coordenar a propaganda nacional, controlar a política cultural do país com o auxílio do Ministério da Educação, promover as manifestações cívicas e fazer a censura dos meios de comunicação e das artes em geral. Além dessas, também distribuía a propaganda do governo através do Serviço de Divulgação do Conselho Nacional de Imprensa (CNI).

Na biografia que escreveu sobre a escritora, Ferreira (1999) acrescenta que Clarice também assumiu as funções de repórter. Nesse período trabalhou com os jornalistas José Conde e Antonio Callado e o escritor Lúcio Cardoso de quem se tornou uma grande amiga. $O$ trabalho na Agência também possibilitou o contato com muitas personalidades.

Mais tarde, em 1941, trabalhando ainda para a Agência, escreveu a reportagem: Onde se ensinará a ser feliz para o jornal de Campinas, Diário do Povo, em 19 de janeiro quando foi cobrir a inauguração do abrigo, cidade das meninas, para garotas pobres, que era um projeto idealizado pela primeira dama Darcy Vargas. Extraímos um trecho da reportagem:

E certamente na primeira noite ao abrigo, cinco mil garotas não poderão adormecer. Na escuridão do quarto, as milhares de cabecinhas, que não souberam indagar a razão de seu abandono anterior, procurarão descobrir a troco de que se lhes dá uma casa, uma cama e comida.

Quando recebiam caridade, recebiam também um pouco de humilhação e desprezo. Não deixava de ser bom, porque sentiam-se quites e muito livres. Livres para o ódio. Mas nas casas onde agora se acomodam, casas limpas, com hora certa de almoço e de jantar, com roupas e livros, são tratadas com naturalidade, com bom-humor...

Mas no momento do adeus à "Cidade" saberão, enfim, que realmente se Ihes dava tanto em troca de alguma coisa. O Brasil, a América, o Mundo precisam de criaturas felizes. Elas riem. Crêem. Amam. As jovens 
mulheres saberão, então, que delas se espera o cumprimento do grave dever de ser feliz. (LISPECTOR apud FERREIRA, 1999, p.76)

Escreveu essa e também outras reportagens enquanto entrevistava personalidades e traduzia poemas.

Mais tarde, Lispector foi transferida para o jornal $A$ Noite e passou a trabalhar como repórter ${ }^{27}$ e lá reencontrou os colegas com os quais trabalhara na Agência Nacional. Concomitantemente com seu ofício jornalístico, ela escrevia contos que foram publicados em jornais e em revistas. Essa prática era comum entre os escritores que utilizavam a imprensa para divulgar seus trabalhos literários.

Em 1944, Clarice Lispector deixou seu trabalho no jornal para acompanhar seu marido em viagem ao exterior. Ele era diplomata e havia sido transferido para Nápoles. Eles moraram na Europa e nos Estados Unidos e, durante o período que estiveram fora do Brasil, Clarice dedicou-se a escrever romances e contos. Quinze anos depois, em 1959, retornou definitivamente para o Brasil, já separada e como escritora consagrada. Havia publicado quatro livros: Perto do Coração Selvagem (1944), premiado como o melhor romance de 1943, O Lustre (1946), A Cidade Sitiada (1949) e Alguns Contos (1952).

Logo que chegou ao Brasil, foi colaborar para dois jornais porque precisava complementar sua renda. Em 1959 para o Correio da Manhã e, em 1960, para o Diário da Noite. Esses trabalhos destinavam-se, especificamente, ao público feminino.

\subsection{Escrevendo para o Correio da Manhã e o Diário da Noite}

Entre agosto de 1959 a fevereiro de 1961, Clarice Lispector colaborou para o jornal o Correio da Manhã, escrevendo a coluna Correio Feminino - Feira de

\footnotetext{
${ }^{27}$ Segundo Gotlib (1995), o jornal A Noite registrou Clarice Lispector como redatora em 2 de março de 1942.
} 
Utilidades, publicada às quartas e às sextas-feiras. Clarice assinava a coluna com o pseudônimo de Helen Palmer. A coluna trazia notas sobre conselhos de beleza, moda, saúde, comportamento, culinária, cuidados com os filhos, cuidados com o lar, enfim, tratava de assuntos sobre a mulher.

Segundo Nunes ${ }^{28}$ (1997), a linha editorial da coluna seguia um plano estratégico de publicidade da empresa de cosméticos Pond's que, à época, divulgava seus produtos de beleza em jornais e revistas. O plano sugeria a criação de uma seção denominada Feira de Utilidades, destinada à mulher, com recomendações sobre o uso de cremes. Não era feita propaganda direta dos produtos, apenas se aconselhava o uso de cremes para que a mulher cuidasse de sua beleza. Os produtos eram anunciados em outras páginas do jornal.

Para compor as notas da coluna, Clarice Lispector, sob o pseudônimo de Helen Palmer, recortava os textos dos materiais que eram enviados pela Agência Periodística Latino-americana (Apla) e por outras agências de notícia.

Salientamos que nesse período o país passava por um processo de desenvolvimento acelerado, como já comentamos no capítulo um. Os padrões de consumo mudavam à medida que novos produtos surgiam no mercado. Os hábitos de higiene e limpeza pessoal ou da casa também se transformaram, inclusive a modernização da beleza, principalmente das mulheres:

O rouge foi sendo preterido pelo blush, o pó-de-arroz pelo pó compacto, as máscaras caseiras de beleza, de abacate, de pepino, de camomila etc., pelos modernos cosméticos, pelos cremes de limpeza, que substituíram o leite de rosas e o de colônia, pelos hidratantes, esfoliantes, rejuvenecedores, da Max Factor, Helena Rubinstein, Elizabeth Arden, ou da Avon, para as classes populares. Aparece o horrível bob de plástico para enrolar cabelo: horrível, mas eficiente. [...] (MELLO; NOVAIS, 2002, p.568)

A coluna acompanhava as transformações não só dos hábitos de consumo como também das mudanças de comportamento das mulheres.

\footnotetext{
${ }^{28}$ A pesquisadora estudou o trabalho de Clarice Lispector para o Correio da Manhã e o Diário da Noite por meio dos documentos da escritora que estão no Museu da Fundação Casa Rui Barbosa, no Rio de Janeiro, doados pelo filho Paulo Gurgel Valente.
} 
Em abril de 1960, Clarice Lispector também passou a colaborar semanalmente para a coluna Só para Mulheres do jornal o Diário da Noite que pertencia aos Diários Associados de Assis Chateaubriand. Nessa época, o editorchefe do jornal era Alberto Dines que havia transformado o DN em um tablóide vespertino.

Clarice elaborava a coluna mas não a assinava, na verdade, ela era a ghostwriter de Ilka Soares. Segundo Dines ${ }^{29}$ :

\begin{abstract}
Eu levei para fazer esse jornal um grupo extremamente interessante, imagine que a página feminina era feita pela Clarice Lispector. Ela não assinava, porque ela não queria assinar, quem assinava era a llka Soares, uma vedete da TV Tupi, que era também dos Associados. A Ilka dava o nome e a Clarice fazia as colunas, mas fazia com cola e tesoura, pegava as revistas francesas, recortava e fazia tudo com muito bom gosto. [...] Aproveitávamos um grupo muito bom, sobretudo, o que se chama hoje de ghostwriter, usava-se os nomes e alguém escrevia.
\end{abstract}

A coluna trazia temas quase que exclusivamente sobre moda, conselhos de beleza, receitas de culinária e novidades, diferentemente da coluna do jornal Correio da Manhã que, além desses, tratava dos cuidados do lar. Segundo Nunes (1997, p. 190), a leitora da coluna Só para Mulheres estava "mais preocupada com sua aparência, deixando de lado os cuidados com a casa".

Nesta coluna, Clarice podia trabalhar seus textos com maior liberdade, pois não havia nenhuma determinação específica do jornal. De acordo com Dines, ela precisava apenas se adaptar ao espírito popular do tablóide e ao universo da artista Ilka Soares. Assim, construiu seus textos de forma muito criativa, as receitas eram escritas numa mistura de ficção e informação, como exemplo, o da receita para matar baratas, publicada com o título Receita de assassinato (de baratas).

Para Nunes (1997), os trabalhos que Clarice Lispector realizou nas páginas femininas dos jornais mostraram que mesmo aceitando o modelo e o papel de colunista que tratava de futilidades, ela apresentou sua leitura de mundo e as representações da mulher que viveu a passagem dos anos 50 e 60, época em que a sociedade brasileira passava por grandes transformações.

\footnotetext{
${ }^{29}$ Trecho da entrevista realizada por Maria Aparecida Costa e Antony Davalle em 2002.
} 
Em 1961, encerravam-se os trabalhos para esses jornais. Em 10 de fevereiro, a coluna Feira de Utilidades do Correio da Manhã deixou de ser publicada e; em março, o Diário da Noite não mais circulava.

Depois de alguns anos, Clarice Lispector voltou a colaborar para a imprensa, isso ocorreu em 1967, para o Jornal do Brasil e; em 1968, para a Revista Manchete.

\section{2 Revista Manchete: Diálogos Possíveis com Clarice Lispector}

Entre maio de 1968 a outubro de 1969, Clarice Lispector colaborou para a revista Manchete ${ }^{30}$ na seção intitulada Diálogos Possíveis com Clarice Lispector. Todos os sábados, a revista publicava as entrevistas que ela realizava com personalidades de variada atividade: cantores, músicos, pintores, atores, escritores, jornalistas, teatrólogos, técnicos de futebol, entre outros.

O texto da entrevista iniciava-se sempre com o nome e uma citação do entrevistado. Se as pessoas eram conhecidas ou não, Clarice sempre as apresentava para o leitor no parágrafo introdutório.

Entrevistou amigos famosos que conheceu quando ainda era casada e vivia no exterior e pessoas com as quais não tinha proximidade, por exemplo, na coluna do dia 22 de março de 1968, a entrevista era com o Governador do Estado da Guanabara, Negrão de Lima que respondeu sobre os problemas das favelas do Rio de Janeiro. No dia 5 de abril de 1969, a entrevistada era a primeira dama D. Yolanda Costa e Silva, que tratou sobre suas viagens pelo mundo e pelo Brasil. O Ministro dos Transportes, Mario Andreazza, também foi entrevistado no dia 10 de maio de 1969.

O tom das entrevistas variava em relação ao entrevistado. Algumas eram mais sérias, outras eram conduzidas em tom de conversa íntima. Os papéis de

\footnotetext{
${ }^{30} \mathrm{Em}$ 1975, Clarice Lispector publicou o livro de Corpo Inteiro que reuniu parte dessas entrevistas. Ela incluiu nessa coletânea a entrevista com o Ministro da Educação Ney Braga que foi realizada posteriormente ao trabalho da Revista Manchete porque entre os anos de 1968 e 1969, o Ministro da Educação era Tarso Dutra.
} 
entrevistador e entrevistado se invertiam no momento em que os entrevistados passavam a fazer perguntas para Clarice.

Os temas eram os mais diversificados, quando os entrevistados eram escritores, costumava perguntar-Ihes sobre o método de criação, de inspiração para o trabalho, os livros que gostavam de ler. Procurava saber se estavam escrevendo algum livro, perguntas essas que tinham muita relação com o seu próprio trabalho, afinal Clarice era também escritora e compartilhava suas experiências com os entrevistados. Com os atores e artistas de teatro procurava saber sobre as peças que encenavam, sobre a rotina do trabalho, questões relacionadas à profissão.

Com as leituras de suas entrevistas, pudemos notar que Clarice tinha muito conhecimento sobre teatro, música, artes. No entanto, este trabalho sempre foi muito criticado por profissionais do jornalismo, principalmente pelo modo como conduzia as entrevistas.

Ainda hoje há aqueles que criticam o trabalho de Clarice Lispector realizado para a Revista Manchete. O colunista da Folha de S. Paulo, Marcelo Coelho ${ }^{31}$ é um deles. Em sua coluna do dia 5 de maio de 2007, sua crítica já está marcada no título, "Clarice 'repórter' inibe entrevistados":

[...] Trabalhando como repórter para o "Jornal do Brasil" e para as revistas "Fatos e Fotos" e "Manchete", a autora de "Perto do Coração Selvagem" era capaz de perguntas de adolescentes, que costumava repetir a cada entrevistado: "o que é o amor?" ou "qual a coisa mais importante do mundo?"

Poucos autores conseguem ser originais diante de indagações desse tipo. "Amor é dádiva, renúncia de si mesmo na aceitação do outro", responde Fernando Sabino. Sem muita paciência, Neruda responde que "o amor é o amor". Chico Buarque sai pela tangente: "não sei definir, e você?" Ao que Clarice Lispector responde: "nem eu". Zagallo, depois de pensar um tempo, dá sua versão: "é um sentimento recíproco". "É bom estar apaixonada?", pergunta Clarice, banalmente, a Elis Regina. Banalmente, a cantora responde: "Bem melhor do que não sentir nada!"

Clarice Lispector não era uma entrevistadora comum, mas não seria possível avaliar seu trabalho apenas por essas perguntas que Marcelo Coelho apresentou em sua crítica. Na entrevista com Chico Buarque, a entrevistadora fez outras perguntas que o jornalista não as considerou em sua crítica.

\footnotetext{
${ }^{31}$ Nesse momento havia sido lançado, pela editora Rocco, o livro Entrevistas, nova coletânea do trabalho realizado por Clarice Lispector para a Revista Manchete. Marcelo Coelho fez crítica a Clarice e ao livro, classificando-o como regular.
} 
Assim, acrescentamos outro trecho da entrevista para que possamos fazer as nossas observações. Clarice pergunta: “- vi você na primeira passeata pela liberdade dos estudantes. Que é que você pensa dos estudantes do mundo e do Brasil em particular?" e Chico Buarque responde: “- No mundo é para mim difícil de falar, mas aqui no Brasil eu sinto em todos os setores um apodrecimento e a impossibilidade de substituição senão por mentalidades completamente jovens e ainda inatingidas por essa podridão. Aqui no Brasil só vejo esta liderança [...]"(LISPECTOR, 1999b, p.68)

Em outra entrevista, realizada com Paulo Autran:

- Paulo Autran é pseudônimo?

- É meu nome mesmo. Nunca usei pseudônimo.

- Boa sorte a sua com um nome belo destes, que prometem tanto, e que soa aos ouvidos como um nome de alguém como você, que está cumprindo os desígnios de um grande ator. Até que ponto Morte e Vida Severina nos representa?

- João Cabral nos apresenta o subdesenvolvimento, e a peça, sendo profundamente brasileira, é universal na medida em que esse tema tem interesse mundial.

- Você refere aos países chamados subdesenvolvidos ou à condição humana e o fruto da falta de justiça social?

- O poema de João Cabral mostra o homem desamparado diante de uma natureza hostil e de condições sociais adversas. É o subdesenvolvimento com todas as suas implicações humanas e sociais [...] (LISPECTOR, 2007, p.133)

Extraímos esses trechos das entrevistas de Chico Buarque e de Paulo Autran para demonstrar que Clarice não fazia perguntas imaturas ou superficiais. Ela tinha preocupação em relacionar suas perguntas não só com o entrevistado como também com as situações da realidade política e social do nosso país. 


\subsection{Clarice Lispector: a coluna semanal no Caderno B}

No dia 19 agosto de 1967, Clarice Lispector passou a colaborar para o Jornal do Brasil, escrevendo uma coluna semanal localizada à página 2 do Caderno B. A pedido de Otto Lara Resende, Alberto Dines convidou-a para escrever para o Caderno B. Segundo Gotlib (1995, p.374), ela aceitara trabalhar para o jornal por motivo de ordem financeira. Sua carteira funcional foi expedida pela Agência JB que a registrou como colaboradora, no dia $1^{\circ}$ de agosto de 1968 e, nesse mesmo mês, inscreveu-se no Sindicato dos Jornalistas Profissionais do Estado de Guanabara.

O fator financeiro poderia ter sido um dos motivos que levou Clarice a trabalhar para o jornal porque a imprensa ainda era um dos meios possíveis de acesso a escritores, de modo a garantir-Ihes renda complementar indispensável pela atividade regular que desempenhavam. Talvez também porque pudesse ter um espaço para a divulgação de seus trabalhos, pois o processo de publicação de um livro não era tarefa simples, nem sempre era possível encontrar uma editora que estivesse disposta a publicar.

Salientamos que nessa época, Clarice Lispector já era famosa, era uma escritora premiada ${ }^{32}$ e, para o Jornal do Brasil, tê-la como colaboradora era algo importante. Alberto Dines ${ }^{33}$, que à época era editor-chefe do Jornal do Brasil, confirmou a importância de seu trabalho. Segundo ele, Clarice ajudou a consolidar o Caderno B que passava a circular aos sábados porque trouxe para o jornal um leitor mais exigente, atendendo assim os objetivos das mudanças implementadas pelo $\mathrm{JB}$.

Nonato Masson ${ }^{34}$, citado por Rito (1990), acrescentou que a consolidação do Caderno B aconteceu devido aos grandes nomes que para ele haviam colaborado como Clarice Lispector, Carlos Drummond, Fernando Sabino e Luis Edgar de Andrade.

\footnotetext{
${ }^{32}$ Em 1962, Clarice Lispector foi agraciada com mais um prêmio, o de Carmen Dolores Barbosa pela obra A maça no escuro como o melhor livro do ano de 1961. (FERREIRA, 1999, p.216)

${ }^{33}$ Entrevistado pela autora deste trabalho de pesquisa no dia 8 de novembro de 2007.

${ }^{34}$ Nonato Masson foi o primeiro editor do Caderno B.
} 
Por quase sete anos, Lispector enviou para a redação do jornal seus textos, período que durou até dezembro de $1973^{35}$. Nesse tempo, seu contato com o público havia se intensificado o que permitiu conquistar projeção. Como exemplo, extraímos trecho do texto Adeus, vou-me embora!, que segue abaixo:

[...] Sou uma colunista feliz. Escrevi nove livros que fizeram muitas pessoas me amar de longe. Mas ser cronista tem um mistério que não entendo: é que os cronistas, pelo menos os do Rio, são muito amados. E escrever a espécie de crônica aos sábados tem me trazido mais amor ainda. Sinto-me tão perto de quem me lê. E feliz por escrever para os jornais que me infundem respeito. Só me ocorre o nome de três ou quatro cronistas mulheres: Elsie Lessa, Rachel de Queiroz, Dinah Silveira de Queirós, eu. Vou telefonar para Elsie, que faz crônica há mais tempo do que eu, para Ihe perguntar que faço com os telefonemas maravilhosos que recebo, das rosas pungentes de tanta beleza que me oferecem, das cartas simples e profundas que me mandam.

[...] escrever para um jornal é uma grande experiência que agora renovo, e ser jornalista, como fui e como sou hoje, é uma grande profissão. O contato com o outro ser através da palavra escrita é uma glória. Se me fosse tirada a palavra pela qual tanto luto, eu teria que dançar ou pintar. Alguma forma de comunicação com o mundo eu daria um jeito de ter. E escrever é um divinizador do ser humano. (LISPECTOR, 1968, p.2).

Esse trecho mostra que o trabalho para o JB rendia-Ihe não só projeção, mas toda uma proximidade com o leitor do jornal que estabelecia contato com a escritorajornalista por telefone e por carta. Em "Adeus, vou-me embora!", a conversa se constrói como resposta às cartas enviadas pelos leitores e Clarice aproveitava o espaço da coluna para respondê-las.

\footnotetext{
${ }^{35}$ Os textos de Clarice Lispector publicados no Jornal do Brasil foram reunidos no livro A descoberta do mundo, publicação póstuma datada de 1984. Mas a reunião feita para esta obra excluiu muitos textos que estavam no caderno B. Só para citar alguns: Vitória nossa / Tanto esforço / O processo publicados em 26 ago.1967; Cem anos de solidão, publicado em 15 nov.1969; A máquina está crescendo / Eu tomo conta do mundo, publicados em 21 de mar.1970; Inauguração solene do futuro, em 18 abr.1970; A pesca milagrosa / Lembrar-se / Crônica Social, A Academia Brasileira de Letras, publicados em 20 fev. 1971; Criar um quadro é criar um mundo novo, publicado em 27 mar.1971 (Anexo F); Cérebro eletrônico, publicado em 23 out.1971; Prêmio Nobel de Literatura no Rio, publicado em 30 out.1971; Autocrítica, Solidão e falsa solidão, publicados em 24 jun.1972; Vários, publicado em 9 set.1972, Uma tarde plena, publicado em 6 jan.1973; O arranjo, publicado em 9 jun. 1973; Mulher demais, publicado em 10 nov.1973 (Anexo A).
} 
Os textos de Clarice Lispector escritos para o Caderno B eram sempre muito variados, podiam ser crônicas, entrevistas, cartas, poemas, bilhetes, e até anúncio de jornal, como este publicado em 19 de outubro, intitulado Precisa-se:

\begin{abstract}
Sendo este um jornal por excelência, e por excelência dos precisa-se e oferece-se, vou pôr um anúncio em negrito: precisa-se de alguém homem ou mulher que ajude uma pessoa a ficar contente porque este está tão contente que não pode ficar sozinha com a alegria, e precisa reparti-la. Paga-se extraordinariamente bem: um minuto paga-se com a própria alegria. É urgente pois a alegria dessa pessoa é fugaz com estrelas cadentes, que até parece que só se viu depois que tombaram; precisa-se urgente antes da noite cair porque a noite é muito perigosa e nenhuma ajuda é possível e fica tarde demais. Essa pessoa que atenda ao anúncio só tem folga depois que passa o horror do domingo que fere. Não faz mal que venha uma pessoa triste porque a alegria que se dá é tão grande que se tem que repartir antes que se transforme em drama. Implora-se também que venha, implora-se com a humildade da alegria-sem-motivo. Em troca oferece-se também uma casa com todas as luzes acesas como uma festa de bailarinos. Dá-se o direito de dispor da copa e da cozinha, e da sala de estar. P.S. Não se precisa de prática. E se pede desculpa por estar num anúncio a dilacerar os outros. Mas juro que há em meu rosto sério uma alegria até mesmo divina para dar. (LISPECTOR, 1968, p.2)
\end{abstract}

Os temas também eram diversificados, Clarice não tratava somente de sua vida pessoal, inclusive sobre acontecimentos do cotidiano que já haviam acontecido ou que estavam acontecendo, como no texto As dores da sobrevivência: Sérgio Porto, publicado em 28 de setembro, em que trata da morte do jornalista:

Não, não quero mais gostar de ninguém porque dói. Não suporto mais nenhuma morte de ninguém que me é caro.

Meu mundo é feito de pessoas que são as minhas - e eu não posso perdêlas sem me perder.

Sem pudor, com lágrimas nos olhos, choro a morte de Sérgio Porto. Ele criava alegria, ele se comunicava com o mundo e fazia esta terra infernal ficar mais suave: ele nos fazia sorrir e rir. Não pude deixar de pensar: ó Deus, por que não eu em lugar dele? O povo sentirá a sua falta, vai ficar mais pobre de sorrisos, enquanto eu escrevo para poucos: então por que não eu em lugar dele? O povo precisa de pão e circo.

Sérgio Porto, perdoe eu não ter dito jamais que adorava o que você escrevia. Perdoe eu não ter procurado você para uma conversa entre amigos. Mas uma conversa mesmo: dessas em que as almas são expostas. Porque você tinha lágrimas também. Atrás do riso. Perdoe eu ter sobrevivido. (LISPECTOR, 1968, p.2) 
Muitos outros acontecimentos são comentados e discutidos em suas colunas, ainda que por meio de fragmentos. Como no dia em que o estudante Edson Luis de Lima e Souto foi morto por um PM, no dia 29 de março e na coluna do dia 6 de abril, intitulada Estado de graça - trecho, Clarice enunciava no final do texto: "P.S. - Estou solidária, de corpo e alma, com a tragédia dos estudantes do Brasil".

Clarice Lispector escreveu para a coluna do Caderno B até dezembro de 1973. No dia 29, despediu-se de seus leitores e de seu trabalho, no texto intitulado, Apenas um cisco no olho:

"Pois como eu já ia dizendo, lembrei-me do Ano-Novo, assim, de repente. Desejo um 1974 muito feliz para cada um de nós."

Há muitos outros trechos dos textos que Clarice Lispector escreveu para o Caderno B com os quais podemos mostrar que ela não escrevia apenas sobre sua vida pessoal, sua família, mas sobre muitos outros temas e nas mais variadas formas para comunicá-los. Apresentamos o estudo de alguns textos de Clarice no capítulo quatro. 


\section{Capítulo 3 - A noção bakhtiniana de enunciado concreto}

\subsection{O enunciado concreto e a comunicação discursiva}

Para fazermos uma leitura adequada dos textos de Clarice Lispector escritos para o Caderno B recorremos aos estudos do pensador russo Mikhail Bakhtin que se dedicou a compreender a comunicação dialógica, o que o fez desenvolver os conceitos referentes ao enunciado concreto, que constitui a unidade da comunicação discursiva e somente através dele os sentidos podem ser compreendidos em plenitude.

Bakhtin (2003, p.328) considera que o enunciado é determinado pela relação imediata com a realidade (situação extraverbal) e com o sujeito; por sua relação com a linguagem como sistema de possibilidades potenciais; como expressão não apenas daquilo que é dado, ou seja, com o que existe fora dele, mas inclusive com o que é criado; e na relação com outros enunciados pertencentes a diferentes esferas da atividade humana e da comunicação.

O enunciado definido como a real unidade da comunicação discursiva se faz pela posição ativa dos sujeitos falantes no processo de comunicação. Bakhtin se põe contrário à definição de que apenas o falante é o sujeito ${ }^{36}$ ativo do processo numa contraposição passiva do ouvinte. Na verdade, o que o pensador deixa claro é que o ouvinte ao perceber e compreender o significado lingüístico do discurso ${ }^{37}$ passa a ocupar, em relação a ele, uma ativa posição responsiva que ocorre sempre em simultaneidade ao ato discursivo do falante. Ou seja, o ouvinte manifesta sua posição de concordância ou discordância frente àquilo de que trata o enunciado. Segundo Bakhtin (2003, p.271) "toda compreensão da fala viva, do enunciado vivo é

\footnotetext{
${ }^{36} \mathrm{O}$ sujeito é entendido por Bakhtin como aquele que participa ativamente do processo de comunicação, seja ele falante ou ouvinte. O sujeito está sempre numa posição ativamente compreensiva. Nesta posição, ele organiza seu enunciado de forma a considerar a resposta prévia do outro. O sujeito é aqui nomeado como representante da comunicação real. Neste momento utilizamos a expressão "sujeito" que extraímos de sua obra, mas depois na leitura dos textos exemplares passamos a utilizar a expressão "enunciador" e/ou "interlocutor" referindo-nos a este mesmo sentido de sujeito.

${ }^{37}$ Para Bakhtin, o discurso faz parte e é o próprio enunciado, este pertencente a um determinado sujeito do discurso. E só por essa forma é que o discurso existe.
} 
de natureza ativamente responsiva [...] toda compreensão é prenhe de resposta, e nessa ou naquela forma a gera obrigatoriamente: ouvinte se torna falante."

A compreensão ativamente responsiva reforça o papel ativo do outro - o ouvinte - no processo da comunicação discursiva. Na verdade, o sujeito falante espera sempre uma resposta do outro, isto é, uma manifestação do ouvinte, uma vez que este é o participante real desta comunicação, nunca podendo ser considerado como o parceiro passivo do processo.

Todo o discurso é orientado para a resposta e ele não pode esquivar-se à influência profunda do discurso da resposta antecipada.

O discurso vivo e corrente está imediata e diretamente determinado pelo discurso-resposta futuro: ele é que provoca esta resposta, pressente-a e baseia-se nela. Ao se constituir na atmosfera do 'já dito', o discurso é orientado ao mesmo tempo para o discurso-resposta que ainda não foi dito, discurso, porém, que foi solicitado a surgir e que já era esperado. (BAKHTIN, 1993, p.89)

Cada resposta que provém da atitude do ouvinte, e que é esperada pelo falante, representa o reconhecimento do discurso, a compreensão de seu significado, além de que compreende uma apreciação (valorização) e a participação deste outro - o ouvinte.

O sujeito falante, por sua vez, também é um respondente ativo no sentido de que seus próprios enunciados estabelecem uma relação com outros enunciados que são anteriores aos seus e alheios a eles, que servem de base para a construção dos seus próprios enunciados, que polemizam com os seus e que são apreciados pelo ouvinte.

Reforçarmos, então, a relevância dada à questão da compreensão ativa e responsiva que o pensador russo traz para a conceituação do enunciado concreto.

O discurso está orientado para a resposta do outro e é determinado pela compreensão de tal resposta. Há, então, uma relação direta que ocorre entre a compreensão e a resposta que permite que o discurso seja compreendido para além de seu contexto, pois o contato com o outro é sempre um novo contato, que se estabelece pelas opiniões, pontos de vista, apreciações e valorizações do discurso do outro (alheio). Com isso a compreensão é enriquecida pela resposta. 
A resposta "cria o terreno favorável à compreensão de maneira dinâmica e interessada. A compreensão amadurece apenas na resposta. A compreensão e a resposta estão fundidas dialeticamente e reciprocamente condicionadas, sendo impossível uma sem a outra."(BAKHTIN, 1993, p.90).

Desta forma, a compreensão se faz como ato ativo porque a resposta compreensível traz algo novo para a compreensão do discurso, ou seja, num discurso já compreendido, algo a mais o complementa e tal fato acontece porque tudo o que é dado ao sujeito falante ocorre no contato com o outro, com o discurso alheio. A compreensão, neste caso, é uma atividade dialógica estabelecida na relação entre sujeitos.

[...] a compreensão ativa [...] determina uma série de inter-relações complexas, de consonâncias e multissonâncias com o compreendido, enriquece-o de novos elementos. É justamente com esta compreensão que o falante conta. Por isso, sua orientação para o ouvinte é a orientação para um círculo particular, para o mundo particular do ouvinte, introduzindo elementos completamente novos no seu discurso: pois para isto concorre a interação dos diversos contextos, diversos pontos de vista, diversos horizontes, diversos sistemas de expressão e de acentuação, diversas 'falas' sociais. O falante tende a orientar o seu discurso, com o seu círculo determinante, para o círculo alheio de quem compreende, entrando em relação dialógica com os aspectos deste âmbito. (BAKHTIN, 1993, p. 91)

Frente ao que foi colocado, podemos dizer que a reposta é ponto fundamental na constituição do enunciado concreto, pois se o enunciado é a unidade da comunicação discursiva e sua natureza é dialógica, a relação discurso-resposta deve ser considerada para que os sentidos sejam atribuídos, pois é no diálogo que eles são gerados, isto é, o sujeito falante apreende-os na relação dialógica estabelecida entre o outro - o ouvinte, não na relação direta com o objeto, isto é, o assunto de que tratam os sujeitos, mas pelas percepções do ouvinte que acabam influenciando a compreensão, o que a torna sempre ativa.

Holquist (2002, p.61) ${ }^{38}$, ao estudar os conceitos de Bakhtin, destaca que "[...] an utterance is never in itself originary: an utterance is always an answer. It is always

\footnotetext{
${ }^{38}$ Michael Holquist é catedrático do Departamento de Literatura Comparada da Universidade de Yale, nos Estados Unidos da América e tem se dedicado também a estudar as obras de Mikhail Bakhtin.
} 
an anwer to another utterance that precedes it, and is therefore always conditioned by, and in turn qualifies, the prior utterance to a greater os lesser degree."39

As idéias colocadas por Holquist vêm reforçar que a resposta é mesmo ponto essencial para que possamos entender a constituição do enunciado e a dimensão valorativa nele instituída.

Como resposta, o enunciado nunca pode ser considerado uma unidade isolada porque "cada enunciado é um elo na corrente complexamente organizada de outros enunciados" (BAKHTIN, 2003, p.272). Há sempre um intercâmbio entre eles, uma vez que todo enunciado concreto mantém uma relação imediata com a realidade, ou seja, com a situação extraverbal do discurso. Além de que estabelece relação com o sujeito real falante. Sendo assim, essas relações dialógicas caracterizam-no como unidade da comunicação discursiva que é plena de sentido.

\subsubsection{Características constitutivas do enunciado concreto}

\subsubsection{Alternância do sujeito falante}

Como o enunciado é marcado pela posição sempre ativa e responsiva dos sujeitos do discurso (falante e ouvinte), a alternância desses sujeitos estabelece os limites dos enunciados, isto é, suas fronteiras. Num diálogo real, as fronteiras podem ser direta e claramente percebidas pelo espaçamento deixado entre os enunciados dos interlocutores, por exemplo, entre uma pergunta e uma resposta, entre uma declaração e outra, entre uma concordância ou discordância. Vale reforçar que a palavra diálogo aqui não se fixa no sentido da troca de sujeitos numa conversa, mas sugere um sentido mais amplo, o de que o diálogo é um processo de interação entre sujeitos sociais que manifestam seus juízos de valor, seus pontos de vista sendo estes expressos em enunciados. Essa manifestação dos sujeitos permite conceituar o enunciado como processo dialógico porque nele estabelecem-se relações que geram sentidos.

\footnotetext{
${ }^{39}$ Um enunciado nunca se origina dele mesmo: um enunciado é sempre uma resposta. É sempre uma resposta a um outro enunciado que o precede e, além disso, está sempre condicionado a ele e, por sua vez, qualifica o enunciado anterior a um grau maior ou menor. (grifos do autor, nossa tradução)
} 
Além do diálogo real, as fronteiras também estão presentes numa obra e são marcadas pela posição ativa responsiva, pois como um enunciado concreto, a obra está sempre relacionada aos enunciados de outra obra, com os quais contém respostas que se alternam em relação ao que foi dito ou ao que vai se dizer; a enunciados outros; anteriores e posteriores.

Salientamos que ao mesmo tempo em que as fronteiras mostram os limites dos enunciados externos e internos, elas evidenciam as relações dialógicas estabelecidas entre esses enunciados.

[...] essas fronteiras, ao conservarem a sua precisão externa, adquirem um caráter interno graças ao fato de que o sujeito do discurso - neste caso $o$ autor de uma obra - aí revela a sua individualidade no estilo, na visão de mundo, em todos os elementos da idéia de sua obra. Essa marca da individualidade, jacente na obra, é o que cria princípios interiores específicos que a separam de outras obras a ela vinculadas no processo de comunicação discursiva de um dado campo cultural: das obras dos predecessores nas quais o autor se baseia, de outras obras da mesma corrente, das obras das correntes hostis combatidas pelo autor, etc. (BAKHTIN, 2003, p. 279, grifos do autor)

Como conceito bakhtiniano, as fronteiras não têm a função de separar os enunciados, mas a de permitir identificá-los - tratam da interface entre aquilo que é dado, que corresponde à realidade imediata, com aquilo que é criado, que é construído pelos sujeitos a partir das diversas interpretações que estes fazem da realidade - estabelecendo, assim, a interação entre os enunciados, sejam eles pertencentes a um diálogo real do cotidiano ou a uma obra.

Holquist (2002, p.61) faz a seguinte leitura sobre as fronteiras:

an utterance [...] is a border phenomenon. It takes place between speakers, and is therefore drenched in social factors. This means that the utterance is also on the border between what is said and what is not said, since, as a social phenomenon par excellence, the utterance is shaped by speakers who assume that the values of their particular community are shared, and thus do not need to be spelled out in what they say.[... $]^{40}$

\footnotetext{
${ }^{40} \mathrm{Um}$ enunciado é um fenômeno de fronteira. Ele ocorre entre falantes e, por esse motivo, está impregnado de fatores sociais. Isto significa que o enunciado está também na fronteira entre o que é dito e o que não é dito; visto como um fenômeno social por excelência, o enunciado é moldado pelos
} 
Nessa leitura, as fronteiras indicam os limites do enunciado por aquilo que é dito e não-dito, e sendo o enunciado um fenômeno social carrega os valores assumidos pelos sujeitos falantes. Todavia, Bakhtin, ao fazer suas reflexões acerca do enunciado, fundamenta que este é determinado também pela relação imediata com a realidade, ou seja, com a situação extraverbal, o que nos permite ampliar considerações para além de uma comunicação representada pela linguagem verbal apenas, incluindo aí outras linguagens constituídas por uma diversidade de códigos. O não-dito pode, então, ser considerado por tudo aquilo que permeia o contexto e os sentidos que dele são atribuídos passam a compor o verbal. O sentido de fronteiras corresponde à própria relação da responsividade ${ }^{41}$ que o enunciado integra.

\subsubsection{Conclusibilidade do enunciado}

Para Bakhtin, as fronteiras se fazem precisas porque o enunciado se constitui por uma conclusibilidade específica, característica esta que, juntamente com a alternância dos sujeitos do discurso, ajuda a estabelecer seus limites como sendo uma espécie de acabamento que possibilita responder ao enunciado, isto é, tomar uma atitude em relação a ele. Num diálogo real, por exemplo, o ouvinte responde ao enunciado do falante quando percebe que ele está concluído e a partir de tal momento o ouvinte faz uma tomada de posição diante dele. Numa obra, os

sujeitos que tomam uma posição diante dos valores de sua comunidade particular que estes são compartilhados e que não precisa ser mencionado claramente. (nossa tradução)

${ }^{41}$ Alguns estudiosos das obras de Bakhtin utilizam outros termos para se referirem ao termo responsividade. Machado (1995, p. 314) faz uso do termo respondibilidade, definindo-o como "ação de responder às necessidades do mundo, seja através de manifestação verbal seja através de outro signo. A respondibilidade evidencia o campo de atuação das relações dialógicas. Termo correspondente ao otvetstvennost, que tem sido traduzido em português por "responsabilidade" como correlativo ao answerability inglês". Já, Sobral (2005, p. 20) propõe o termo responsibilidade para traduzir o termo otvetstvennost, justificando que "une responsabilidade, o responder pelos próprios atos, a responsividade, o responder a alguém ou a alguma coisa. O objetivo é designar por meio de uma só palavra tanto o aspecto responsivo como o da assunção de responsabilidade do agente pelo seu ato, um responder responsável que envolve necessariamente um compromisso ético do agente". Optamos neste trabalho por responsividade porque se refere à atitude responsiva dos sujeitos falantes (a resposta). 
pontos de vista do sujeito do discurso ficam evidenciados como seus numa relação de interação com outros enunciados, em resposta a eles.

"A conclusibilidade do enunciado é uma espécie de aspecto interno da alternância dos sujeitos do discurso; essa alternância pode ocorrer precisamente porque o falante disse (ou escreveu) tudo o que quis dizer em dado momento ou sob dadas condições". (BAKHTIN, 2003, p.280, grifo do autor). Sendo assim, as fronteiras evidenciam o enunciado tanto na relação imediata com a realidade exterior (situação extraverbal), com os enunciados alheios quanto na sua constituição interna, marcada pela individualidade do autor da obra.

O autor aqui é representado na linguagem por aquele que em posição valorativa recorta os eventos da vida cotidiana e os reorganiza como um ato criativo seu: um ponto de vista criador. Este torna-se criador à medida que se relaciona com outros pontos de vista criadores. E somente sobre fronteiras é que ganha singularidade, encontra fundamento e razão sólida. Na visão bakhtiniana, o autor é visto como o artista que não se envolve como participante direto do acontecimento:

\begin{abstract}
ele ocupa uma posição essencial fora do acontecimento enquanto assistente desinteressado, mas que compreende o sentido axiológico daquilo que se realiza; não se submete ao acontecimento, mas participa do seu suceder: pois sem ter uma participação axiológica em certo grau, não se pode contemplar o acontecimento enquanto acontecimento.

Esta exterioridade [...] permite que a atividade artística una, formule e conclua o acontecimento a partir do lado de fora. No interior do próprio conhecimento e do próprio ato esta unificação e este acabamento são radicalmente impossíveis: nem a realidade do conhecimento pode permanecer fiel a si mesma e se unir à realidade; é preciso uma posição axiológica substancial fora do conhecimento cognoscível, imperativo e agente, sobre o qual se poderia efetuar esta unificação e este acabamento[...] (BAKHTIN, 1993, p.36, grifos do autor)
\end{abstract}

Essa espécie de acabamento é determinada, segundo Bakhtin (2003, p. 281), por três fatores que estão estritamente ligados ao todo do enunciado: a "exauribilidade do objeto e do sentido; o projeto de discurso ou vontade do discurso do falante; as formas típicas composicionais e de gênero de acabamento". 


\subsection{Exauribilidade do objeto e do sentido}

Este fator refere-se ao esgotamento dado ao conteúdo temático do enunciado que se dá numa relação imediata com a esfera ${ }^{42}$ da comunicação discursiva. Quando uma determinada esfera não está disposta a criações, pois há ausência do elemento criativo, o esgotamento do objeto e do sentido do tema se dá quase que completo. Para Bakhtin as esferas oficiais como a das ordens militares são um dos exemplos em que a exauribilidade acontece quase que plenamente.

Quando a esfera permite criações, o esgotamento se dará em um mínimo de acabamento, pois sempre haverá abordagens diversas a se fazer sobre o tema ${ }^{43}$. Bakhtin cita a esfera científica como um exemplo em que há um relativo esgotamento em relação ao tema do enunciado uma vez que a abordagem segue uma idéia definida pelo autor. Entendemos que num trabalho científico, o tema é tratado sob uma problematização específica, determinados objetivos são traçados pelo autor, assim como outros elementos que demonstram sua posição e que estão presentes no trabalho. Acrescentamos a esfera jornalística como outro exemplo em que não existe uma única exauribilidade ou possibilidade de abordagem, isto é, o tratamento dado ao objeto e ao sentido desta é também sempre inesgotável.

\subsection{Projeto de discurso ou vontade discursiva do falante}

A idéia definida pelo autor (seu projeto de discurso), além de estar relacionada à exauribilidade, é também um outro fator que determina o acabamento do enunciado. Para Bakhtin (2003, p.281), o enunciado traz a "idéia verbalizada" e a

\footnotetext{
${ }^{42}$ Bakhtin (2003) utiliza também a expressão campo que remete ao sentido de esfera da atividade humana e da comunicação. Cada campo ou esfera possui condições específicas de comunicação discursiva que envolve a situação de comunicação, a relação do falante com outros participantes da comunicação discursiva e a posição social desses sujeitos. Podemos observar o uso de campo tanto na obra Estética da criação verbal como na obra Problemas da poética de Dostoievski. Optamos pela expressão esfera.

${ }^{43}$ Bakhtin (1993, p.139-140) considera o tema como as informações e opiniões do sujeito que fala e daquilo que ele fala no cotidiano. "Qualquer conversa é repleta de transmissões e interpretações das palavras dos outros. A todo instante se encontra nas conversas 'uma citação' ou 'uma referência' àquilo que disse uma determinada pessoa, ao que 'se diz' ou àquilo que 'todos dizem', às palavras de um interlocutor, às nossas próprias palavras anteriormente ditas, a um jornal, a um decreto, a um documento, a um livro, etc."
} 
partir dela "medimos a conclusibilidade do enunciado". Neste caso, o acabamento também se estabelece pela escolha que o sujeito falante ou autor da obra faz para desenvolver o tema ou até mesmo na escolha do objeto do enunciado, caracterizando-o como um projeto de discurso ou uma intenção discursiva desses sujeitos.

A idéia ${ }^{44}$ verbalizada, que é a própria manifestação da vontade discursiva do falante, determina as fronteiras do enunciado porque estabelece tudo o que o sujeito diz, pelo tom que é dado na abordagem do tema e por tal idéia responder a enunciados outros, antecedentes e alheios aos seus. É importante ressaltar que a intenção do sujeito falante é apreendida pelo outro - ouvinte e participante ativo do processo comunicativo - porque toda a comunicação está orientada para a situação em que os participantes vivenciam, ou seja, para a situação em que estão envolvidos.

Além de ter uma relação direta com o fator da exauribilidade, a intenção discursiva do falante está também vinculada ao terceiro fator; o das formas típicas composicionais e de gênero de acabamento, pois o sujeito, autor do enunciado, escolhe uma forma de composição para construir seu enunciado.

\subsection{Formas típicas composicionais e de gênero discursivo}

A intenção discursiva com todas as características individuais e subjetivas do falante é aplicada e adaptada a um gênero escolhido e específico de uma dada esfera da comunicação. A intenção discursiva do sujeito falante se realiza na escolha de determinado gênero do discurso.

\footnotetext{
${ }^{44}$ Segundo Bakhtin (1997, p.87), "a idéia é interindividual e intersubjetiva, a esfera da sua existência não é a consciência individual mas a comunicação dialogada entre as consciências. A idéia é um acontecimento vivo, que irrompe no ponto de contato dialogado entre duas ou várias consciências. Neste sentido a idéia é semelhante ao discurso, com o qual forma uma unidade dialética. Como o discurso, a idéia quer ser ouvida, entendida e "respondida" por outras vozes e de outras posições". (grifos do autor)
} 
Essa escolha é determinada pela especificidade de um dado campo da comunicação discursiva, por considerações semântico-objetais (temáticas), pela situação concreta da comunicação discursiva, pela composição pessoal dos seus participantes, etc. [...]

Falamos apenas através de determinados gêneros do discurso, isto é, todos os nossos enunciados possuem formas relativamente estáveis e típicas de construção do todo. Dispomos de um rico repertório de gêneros de discurso orais (e escritos). Em termos práticos, nós os empregamos de forma segura e habilidosa, mas em termos teóricos podemos desconhecer inteiramente a sua existência. [...] nós falamos por gêneros [...]. Até mesmo no bate-papo mais descontraído e livre nós moldamos o nosso discurso por determinadas formas de gênero, às vezes padronizadas e estereotipadas, às vezes mais flexíveis, plásticas e criativas (a comunicação cotidiana também dispõe de gêneros criativos). (BAKHTIN, 2003, p.282, grifos do autor).

O gênero do discurso é um dos fatores que estabelece a conclusibilidade do enunciado concreto, pois todo enunciado é constituído por formas que, de acordo com Bakhtin, são relativamente estáveis. O enunciado se constrói a partir de uma dada situação discursiva que está relacionada a uma determinada esfera da comunicação.

Os gêneros existem e são difundidos no cotidiano da comunicação, fornecendo-nos as mais variadas formas e, por estarem previamente disponíveis, são estáveis, mas não fixas uma vez que o sujeito produz seu enunciado tanto como expressão daquilo que the é dado pela situação vivenciada como expressão do que ele cria.

Desta forma, a intenção discursiva do sujeito se desenvolve na escolha de certo gênero discursivo, seja nas formas mais flexivas e críticas da comunicação ou até quando o discurso é moldado em formas padronizadas, mesmo nestas é possível haver um tom expressivo, ainda que sutil, capaz de marcar a presença do sujeito. Para Bakhtin, a forma do gênero pode ser transferida de uma esfera para outra, fazendo com que ocorra uma reacentuação à medida em que os diferentes gêneros das diferentes esferas da comunicação se misturam.

Além dos gêneros padronizados, o sujeito pode pretender fazer uso de gêneros mais criativos e livres que também estão disponíveis em diferentes esferas da comunicação discursiva. No entanto, o pensador reforça que o uso criativo e livre de tais gêneros não representa a criação de um novo gênero, mas uma reelaboração e uma atualização do todo discursivo. O sujeito aproveita da 
combinação e composição de gêneros criativos e livres para manifestar sua intenção discursiva no enunciado que ele constrói.

Há uma diversidade de gêneros do discurso e sua riqueza está nas possibilidades inesgotáveis de uso nas diversas esferas da atividade humana.

[...] devemos incluir as breves réplicas do diálogo do cotidiano (saliente-se que a diversidade das modalidades de diálogo cotidiano é extraordinariamente grande em função do seu tema, da situação e da composição dos participantes), o relato do dia-a-dia, a carta (em todas as suas diversas formas), o comando militar lacônico padronizado, a ordem desdobrada e detalhada, o repertório bastante vário (padronizado na maioria dos casos) dos documentos oficiais e o diversificado universo das manifestações publicísticas (no amplo sentido do termo: sociais, políticas); mas aí também devemos incluir as variadas formas das manifestações científicas e todos os gêneros literários (do provérbio ao romance de muitos volumes). (BAKHTIN, 2003, p.262)

A essa variedade de manifestações discursivas que caracterizam os gêneros, podemos acrescentar ainda as manifestações jornalísticas como o editorial, a notícia, o artigo, a reportagem, a coluna, outras. A heterogeneidade das manifestações dános a dimensão de formas possíveis que o sujeito pode se apropriar para fazer a construção composicional do enunciado, ou das possibilidades combinatórias de que pode fazer uso para realizar o seu projeto de discurso.

A questão dos gêneros do discurso é vista como imprescindível para o estudo da própria natureza do enunciado e, conseqüentemente, para o estudo da comunicação discursiva. Para dar conta da complexidade e da heterogeneidade desses gêneros sem que se perca também a essencialidade de suas diferenças, Bakhtin (2003) propõe duas modalidades de gêneros discursivos: o primário e o secundário.

Os gêneros discursivos primários são simples, formam-se na réplica do diálogo cotidiano e estabelecem um vínculo imediato com a realidade concreta (extraverbal). Os gêneros secundários, por sua vez, são complexos porque se constroem e se formam em situações de convívio cultural mais complexo, mais desenvolvido e organizado. Como exemplos desses gêneros estão: o artístico, o científico, o sociopolítico e podemos incluir o jornalístico.

Os gêneros secundários, no processo de sua formação, agregam os diversos gêneros primários e passam a reelaborá-los; é, então, nesse processo que os 
gêneros primários se transformam e adquirem qualidade especial: ao serem incorporados pelos gêneros discursivos secundários deixam de ter vínculo imediato estabelecido com a realidade concreta com a qual se formaram e passam a integrar a realidade concreta dos gêneros secundários. Os gêneros discursivos da esfera jornalística, por exemplo, integram gêneros de outras esferas como a carta, o relato do dia-a-dia, a entrevista, entre outros que interagem de forma a se modificarem e se complementarem.

Segundo Morson e Emerson $(1999)^{45}$, os gêneros primários, para Bakhtin, quando incorporados pelos gêneros secundários, conservam muito do tom que lhes é característico. Isso ocorre porque o processo de formação dos gêneros secundários implica em reacentução dos gêneros primários.

No estudo que faz sobre as modalidades de gêneros do romance ${ }^{46}$, Bakhtin explica que os gêneros primários integram a realidade concreta no próprio conjunto do romance como um acontecimento artístico-literário, pertencente ao gênero secundário, e não mais da vida cotidiana. O vínculo com a realidade apenas ocorre através da obra e não mais por réplicas de diálogo cotidiano. A obra, então, passa a ser a representação de uma inter-relação entre enunciados que se transformam, mas que ao mesmo tempo se completam, estabelecendo um elo na comunicação discursiva entre os discursos precedentes e que passam a representar a obra sendo esta a que registra os discursos e que garante a continuidade das idéias.

Quando articulamos essas formulações aos gêneros da esfera jornalística, podemos observar, neste caso, que os gêneros primários representados pelas réplicas do cotidiano: as falas de autoridades governamentais, de representantes de instituições, de autoridades de áreas específicas como médicos, economistas, cientistas, jornalistas, artistas, estudantes etc., de representantes de instituições públicas e privadas, entre outros enunciados reais que estabelecem ligação imediata com a realidade concreta, estão integrados aos gêneros secundários (complexos)

\footnotetext{
${ }^{45}$ Gary Saul Morson e Caryl Emerson são estudiosos dos principais trabalhos e conceitos desenvolvidos pelo pensador Mikhail Bakhtin.

${ }^{46} \mathrm{O}$ romance é o objeto de estudo das pesquisas de $\mathrm{M}$. Bakhtin por considerá-lo um fenômeno pluriestilístico, plurilíngüe e plurivocal uma vez que se constitui pela diversidade social de linguagens que são organizadas artisticamente, até de línguas e de vozes individuais. "A estratificação interna de uma língua nacional única em dialetos sociais, maneirismos de grupos, jargões profissionais, linguagens de gêneros, fala de gerações, das idades, das tendências, das autoridades, dos círculos e das modas passageiras, das linguagens de certos dias e mesmo de certas horas [...]" (BAKHTIN,1993, p.74)
} 
que nesta esfera da atividade humana podem ser exemplificados pela notícia, pela reportagem, pela entrevista, pelo artigo, pelo editorial, inclusive pela coluna, isto é, pelos próprios gêneros da atividade jornalística. Como os gêneros secundários incorporam e reelaboram os gêneros primários, estes passam a integrar a realidade concreta pelo todo da notícia, da reportagem, da coluna etc., que são formas culturais elaboradas, organizadas e determinadas pela especificidade da atividade jornalística.

Para Bakhtin (2003, p. 262), cada esfera da atividade humana elabora "seus tipos relativamente estáveis de enunciados", denominados por gêneros do discurso. São tipos relativamente estáveis porque os gêneros discursivos primários ao serem incorporados pelos gêneros secundários perdem o vínculo imediato da realidade, mas sua forma e seu significado cotidiano passam a integrar à obra ${ }^{47}$ (gênero secundário) como um todo porque há o registro de uma "memória criativa":

[...] o gênero sempre é e não é o mesmo, sempre é novo e velho ao mesmo tempo. O gênero renasce e se renova em cada nova etapa do desenvolvimento da literatura e em cada obra individual de um dado gênero. Nisto consiste a vida do gênero. [...] vive do presente mas sempre recorda o seu passado, o seu começo. É o representante da memória criativa no processo de desenvolvimento literário. É precisamente por isto que tem a capacidade de assegurar a unidade e a continuidade desse desenvolvimento. (BAKHTIN, 1997, p.106, grifos do autor)

O estudo dos gêneros discursivos é de extrema importância para a compreensão da natureza do enunciado. Na comunicação, tanto os gêneros primários quanto os gêneros secundários permitem uma estudo mais adequado diante da complexidade do enunciado. Além de que a relação mútua de ambos os gêneros dá o acabamento do todo do enunciado que lhe assegura a posição responsiva do falante, isto é, permite que ocorra a alternância dos sujeitos do discurso.

\footnotetext{
${ }^{47}$ Bakhtin nomeia "obra" toda as manifestações pertencentes ao gênero secundário, como explica Machado (2005, p. 155), numa releitura que faz dos gêneros discursivos, "produzido a partir de códigos culturais elaborados, como a escrita."
} 


\subsubsection{A relação do enunciado com o próprio falante e com o outro}

Uma terceira característica do enunciado refere-se à relação deste com o próprio falante e com outros sujeitos participantes da comunicação discursiva. Relação esta que determina o caráter estilístico-composicional de um enunciado, conceituado por Bakhtin (2003) a partir de dois elementos: as idéias do sujeito falante que estão centradas no objeto e no sentido; a expressividade valorativa do falante em relação ao conteúdo do objeto e do sentido de seu enunciado.

Todo o enunciado concreto se caracteriza pela posição sempre ativa do sujeito falante diante do conteúdo do objeto e do sentido do enunciado. Tal posição se faz pelas escolhas dos recursos lingüísticos utilizados pelo falante bem como pelas formas - gêneros discursivos - que seleciona para materializar suas idéias, 0 que determina o estilo e a composição do enunciado. Além dessa relação, o estilo e a composição também são determinados pela expressividade valorativa dada pelo sujeito falante ao conteúdo e ao sentido do enunciado. Aos recursos lingüísticos são somados tons expressivos cuja valorização não escapa às idéias do próprio falante.

Bakhtin não considera a possibilidade de um enunciado ser absolutamente neutro, pois acredita na relação subjetiva existente entre falante e enunciado, isto é, sua posição impossibilita que haja neutralidade, pois sua expressão, constituída no próprio enunciado, representa uma avaliação real determinada.

Os recursos lingüísticos em si nada valorizam, não carregam um juízo de valor, mas à medida que os recursos são utilizados como unidades de significação, ou seja, como enunciados plenos e acabados passam a determinar a expressão valorativa do sujeito falante em relação ao que diz e como diz.

Quando escolhemos as palavras no processo de construção de um enunciado, nem de longe as tomamos sempre do sistema da língua em sua forma neutra, lexicográfica. Costumamos tirá-las de outros enunciados e antes de tudo de enunciados congêneres com o nosso, isto é, pelo tema, pela composição, pelo estilo; conseqüentemente, selecionamos as palavras segundo a sua especificação de gênero. O gênero do discurso não é uma forma da língua mas uma forma típica do enunciado; como tal forma, o gênero inclui certa expressão típica a ele inerente. No gênero a palavra ganha certa expressão típica. Os gêneros correspondem a situações típicas da comunicação discursiva, a temas típicos, por conseguinte, a alguns contatos típicos dos significados das palavras com a 
realidade concreta em circunstâncias típicas. (BAKHTIN, 2003, p.292-293, grifos do autor)

$\mathrm{Na}$ comunicação discursiva, segundo as concepções de Bakhtin, o sujeito falante considera as palavras sob os seguintes aspectos: como aquelas que pertencem à língua neutra; como as que pertencem aos outros - são alheias e que carregam os ecos de outros enunciados; como aquelas pertencentes ao sujeito falante numa determinada situação e estão carregadas da intencionalidade discursiva desse sujeito. Esses aspectos evidenciam as relações dialógicas estabelecidas entre os enunciados. Numa obra, é possível identificar os enunciados pertencentes ao sujeito falante/autor da obra e os enunciados outros (alheios) com os quais mantêm relação de resposta, de interação constante entre o enunciado particular de um e o dos outros. Nos enunciados, as palavras incorporam aspectos expressivos e em determinadas situações discursivas podem gerar pensamentos determinantes.

\begin{abstract}
Em cada época, em cada círculo social, em cada micromundo familiar, de amigos e conhecidos, de colegas, em que o homem cresce, vive, sempre existem enunciados investidos de autoridade que dão o tom, como as obras de arte, ciência, jornalismo político, nas quais as pessoas se baseiam, as quais elas citam, imitam, seguem. Em cada época e em todos os campos da vida e da atividade, existem determinadas tradições, expressas e conservadas em vestes verbalizadas: em obras, enunciados dos "senhores do pensamento" de uma época verbalmente expressas, algumas tarefas fundamentais, lemas, etc.(BAKHTIN, 2003, p.294).
\end{abstract}

A partir das idéias de Bakhtin, percebemos que em determinada época e em determinadas esferas da atividade humana, há pensamentos que podem se tornar predominantes, são enunciados alheios, externos que estabelecem uma interrelação com outros enunciados: os internos, seja do diálogo real ou da obra. Ao mesmo tempo em que há um diálogo entre os diversos enunciados, é possível identificar as idéias que predominam como expressões valorativas que são assimiladas, reelaboradas e reacentuadas numa interação sempre contínua.

A questão da expressividade, elemento que determina as características estilístico-composicionais do enunciado passa por um processo de escolha feito pelo sujeito do discurso (falante/autor) em relação às palavras que compõem o enunciado. Tal escolha se faz pelo valor emocional - pelo elemento axiológico - que elas 
possuem. A palavra isolada ${ }^{48}$ quando pronunciada com entonação expressiva passa a constituir-se como enunciado pleno, acabado. A seleção das palavras faz parte do projeto individual do discurso que o sujeito constrói a partir das palavras que seleciona, que de alguma maneira correspondem à expressão do conjunto do seu enunciado e por aquelas que rejeita. O sujeito escolhe as palavras que de alguma forma atendem aos objetivos de sua expressão. É sempre importante reforçar que a força da expressividade reside no enunciado concreto, e somente como enunciado é que os sentidos podem ser atribuídos.

[...] a emoção, o juízo de valor, a expressão são estranhos à palavra da
língua e surgem unicamente no processo de seu emprego vivo em um
enunciado concreto. Em si mesmo, o significado de uma palavra (sem
referência à realidade concreta) é extra-emocional. Há palavras que
significam especialmente emoções, juízos de valor: "alegria", "sofrimento",
"belo", "alegre", "triste", etc. Mas também esses significados são igualmente
neutros como todos os demais. O colorido expressivo só se obtém no
enunciado. [...] (BAKHTIN, 2003, p. 292)

No entanto, Bakhtin atenta para a questão de que o sujeito do discurso, ao construir o enunciado, costuma extrair as palavras de outros enunciados que possuem uma certa semelhança em relação ao seu, seja pelo tema, pela composição, pelo estilo e até pelas formas típicas de construção dos enunciados que são os gêneros do discurso, estes que carregam expressões típicas correspondentes a determinadas situações da comunicação discursiva, de determinadas esferas da atividade humana.

Tem-se, então, o enunciado numa relação de interação, estabelecida com outros enunciados. A relação é o ponto central sobre o estilo, este que não é visto pelo viés apenas do falante com sua visão de mundo, seus pontos de vista em relação ao objeto do enunciado, inclusive como relação estabelecida entre outros enunciados; como resposta a enunciados precedentes, bem como a enunciados subseqüentes que estão ligados à atitude responsiva do ouvinte, este que é o participante ativo da comunicação discursiva, uma vez que o enunciado sempre se constitui pela a alternância dos sujeitos do discurso que estabelecem os limites

\footnotetext{
${ }^{48}$ Isolado refere-se aqui à palavra vista como unidade apenas da língua, unidade esta ausente de propriedades constitutivas de um enunciado, uma vez que não suscita a imediata atitude responsiva do outro, não há expressividade.
} 
precisos do enunciado, ou seja, suas fronteiras, idéias estas já expostas neste trabalho.

O estilo, na concepção bakhtiniana, está na relação dialógica entre os enunciados criados e os dados (alheios) e pela relação entre sujeitos do discurso falante e ouvinte. Desta forma, o conceito de estilo leva em consideração também o ouvinte, pois o enunciado destina-se ao outro, que pode ser o participante direto do diálogo, o representante de uma coletividade de determinada esfera comunicativa ou até mesmo aquele indefinido, sempre há um outro a quem o enunciado está direcionado.

Seguindo o pensamento de Bakhtin, Brait (2004, p.140) acrescenta que o estilo é de natureza social, envolve "o autor, o herói (no caso o 'assunto') e o ouvinte como fatores constitutivos de uma obra". Essa relação com o outro participante ativo determina a escolha dos gêneros do discurso, a composição e o estilo do enunciado.

\begin{abstract}
Ao construir o meu enunciado, procuro defini-lo de maneira ativa; por outro lado, procuro antecipá-lo, e essa resposta antecipável exerce, por sua vez, uma ativa influência sobre o meu enunciado (dou resposta pronta às objeções que prevejo, apelo para toda sorte de subterfúgios, etc.). Ao falar, sempre levo em conta o fundo aperceptível da percepção do meu discurso pelo destinatário: até que ponto ele está a par da situação, dispõe de conhecimentos especiais de um dado campo cultural da comunicação, levo em conta as suas concepções e convicções, os seus preconceitos (do meu ponto de vista), as suas simpatias e antipatias - tudo isso irá determinar a ativa compreensão responsiva do meu enunciado por ele (BAKHTIN, 2003, p.302, grifos nossos).
\end{abstract}

Frente a isso, é possível dizer que o sujeito falante irá sempre considerar o ouvinte para produzir os enunciados, seja qual for a esfera da comunicação discursiva, a atitude responsiva do outro será considerada para que o falante possa trabalhar com o tema do qual se apropriou e o qual desenvolverá. Mesmo estando distante do ouvinte, ou se considerá-lo desconhecido, ainda assim é possível traçar seus aspectos e suas concepções, pois todas elas são determinadas pela esfera da atividade humana e da vida em que o enunciado está inserido. Se pensarmos na esfera jornalística, o jornal como lugar de produção de enunciados permite que os jornalistas e outros colaboradores escrevam seus enunciados para o público leitor de determinado jornal, numa determinada época, com características próprias. 0 
sujeito falante/autor percebe e imagina o destinatário para quem o enunciado está endereçado. Tal fato se constrói pelas cartas que o leitor envia ao jornal ou ao colunista.

Muitas vezes nas notícias e nas reportagens, o jornalista na qualidade de sujeito falante retoma alguns pontos relacionados ao fato que em momento anterior haviam sido abordados porque considera a retomada algo necessário para ajudar a situar o leitor (destinatário) quanto ao assunto tratado, caso ele não venha a se lembrar ou não tenha lido sobre o fato. É um típico exemplo em que o enunciado demonstra um claro vínculo com outros enunciados, precedentes e também subseqüentes, porque todo enunciado se constrói levando em consideração a ativa compreensão responsiva do ouvinte que neste exemplo é o leitor. No entanto, mesmo que a retomada de tais pontos não ocorra, ainda assim o enunciado estabelecerá relação com outros enunciados, pois sua natureza é dialógica.

As relações dialógicas se estabelecem na construção do enunciado concreto e para estudarmos o fenômeno dialógico precisamos considerar o conceito de enunciado em suas particularidades: alternância dos sujeitos do discurso; a conclusibilidade do enunciado e os fatores que determinam seu acabamento; a relação do enunciado com os sujeitos do discurso e a relação de interação entre tais peculiaridades e fatores.

O estudo do enunciado deve, então, ser compreendido como processo de produção (pela sua materialidade verbal e como um acontecimento único e pela construção que envolve diálogo entre enunciados externos e internos (situação dada e criada).

\subsubsection{A visão do texto como enunciado concreto.}

O estudo sobre o conceito de enunciado concreto, apresentado no item anterior, é tomado aqui como base para a conceituação de texto, este que é objeto de nossa pesquisa na busca da identificação de sentidos que dele podem ser atribuídos.

O texto, determinado como enunciado, se constitui pela relação estabelecida entre o texto (enunciado) que é a realização de uma idéia e o próprio sujeito (autor). 
Além desses elementos, o texto também se relaciona com o que está fora dele (o dado). Segundo Bakhtin (2003, p.309-310), cada texto pressupõe um sistema de linguagem, de signos, o que é comum a um dado grupo. "Esse sistema corresponde no texto tudo o que é repetido e reproduzido e tudo o que pode ser repetido e reproduzido [...]". São repetições de pensamentos, atitudes, vontades, vivências anteriores que se relacionam às produções posteriores. Aquilo que é criado vinculase a idéias, sentidos e significados outros em processo de inter-relações sempre dinâmicas.

Nesta visão, a reprodução é sempre um novo acontecimento, algo singular, pois o sujeito, na verdade, faz uma retomada do texto, faz uma nova execução, dáIhe uma nova função, isto é, um novo propósito. Há sempre a presença da resposta compreensiva e valorativa do sujeito.

Desta forma, o sujeito (autor) do texto realiza sua intenção (idéia) porque há um sistema de códigos culturais ${ }^{49}$ comuns ao sujeito e aos participantes ativos da comunicação. São códigos partilhados que interagem na construção do texto (enunciado). Ao mesmo tempo em que os enunciados outros (exteriores) se interrelacionam ao texto do sujeito (autor), o texto pode ser identificado por uma construção discursiva marcada pela singularidade, pela individualidade e pela criatividade desse sujeito, tornando o texto como algo único bem como pela realização da idéia do autor, isto é, a que o texto se propõe, sua finalidade, criando o que Bakhtin denomina de "contexto emoldurador", pois a idéia está vinculada às formas típicas de composição e de gênero de acabamento uma vez que o autor escolhe uma forma para emoldurar seu enunciado.

O texto é o próprio contexto porque estabelece um vínculo com o que está fora, com o que é dado, assim o texto se desenvolve entre as fronteiras do dado e do criado, no encontro de duas consciências.

[...] O enunciado nunca é apenas um reflexo, uma expressão de algo já existente fora dele, dado e acabado. Ele sempre cria algo que não existia antes dele, absolutamente novo e singular, e que ainda por cima tem relação com o valor (com a verdade, com a bondade, com a beleza, etc.). Contudo alguma coisa criada é sempre criada a partir de algo dado (a linguagem, o fenômeno observado da realidade, um sentimento vivenciado,

\footnotetext{
${ }^{49}$ Sobre sistemas de códigos culturais numa visão bakhtiniana sobre os gêneros do discurso, ver MACHADO, Irene. Gêneros do discurso. In: BRAIT, Beth (org.). Bakhtin: conceitos-chave. São Paulo: Contexto, 2005.
} 
o próprio sujeito falante, o acabado em sua visão de mundo, etc.). Todo o dado se transforma em criado. (BAKHTIN, 2003, p.326)

Além do ponto de que a criação ocorre a partir daquilo que é dado, há um outro ponto fundamental na questão da criação: a compreensão. A criação é a resposta do que foi compreendido pelo sujeito. Compreensão e resposta estão intrinsecamente ligadas, pois só é possível responder a algo, isto é, manifestar uma posição valorativa quando há compreensão das idéias que estão presentes em outros textos. Se não existe compreensão, tem-se a simples reprodução de idéias desconexas, sem criar nada novo. Isso porque a compreensão é um ato ativo, é uma atividade dialógica estabelecida na relação entre sujeitos e, no diálogo, é que se estabelecem os sentidos porque o sujeito-autor cria seu texto (enunciado) a partir de enunciados heterogêneos, que estão e são alheios ao dele. $O$ fato de haver uma tomada de consciência das outras idéias, por sua vez, já estabelece uma relação de diálogo com essas idéias.

As relações dialógicas compreendem e embasam o conceito de dialogismo que vai além das formas de discussão, de polêmica e de conversa, ele também inclui o aprendizado, as sobreposições do sentido sobre o sentido, a combinação de vozes, a compreensão para além dos limites do compreensível ${ }^{50}$; são relações amplas, complexas e diversificadas.

Para entendermos as formas complexas que envolvem o conceito de dialogismo, abordaremos a relação tempo-espaço na constituição do enunciado.

\subsubsection{O tempo e o espaço na construção dos pontos de vista}

O conceito de enunciado que Bakhtin formula como sendo o próprio conceito de texto considera os pontos de vista, as opiniões dos sujeitos falantes como atividade ativa e responsiva que determina o caráter dialógico do enunciado/texto

\footnotetext{
${ }^{50}$ Entender o enunciado, em sua forma plena, é preciso considerar os elementos extralingüísticos (dialógicos), bem como o que está ligado a outros enunciados. Os elementos extralingüísticos além de representarem o externo (extraverbal) também penetram o enunciado por dentro (interno).
} 
que se desenvolve sempre na fronteira de dois sujeitos, na inter-relação e na interação entre suas idéias, que se realizam em situações concretas da realidade.

Assim, os sentidos do texto são interpretados pelo contato dialógico entre os textos (enunciados). "O texto só tem vida contatando com outro texto (contexto)" (BAKHTIN, 2003, p.401). O contato dialógico entre os textos envolve sujeitos, consciências, é a relação estabelecida entre o eu e o outro. Ao mesmo tempo, o texto se caracteriza como o próprio contexto (que se constitui pelos aspectos externos e internos, isto é, o que é dado, o que está fora e o que é criado) e, desta forma, a interpretação ${ }^{51}$ desenvolve-se no nível do tempo e do espaço. É o que Bakhtin determina como movimento dialógico da interpretação: o retrospectivo, um dado texto que se refere a contextos do passado e o prospectivo, aquele que antecipa o contexto futuro, o desejado.

Desta forma, o texto atualiza os sentidos porque nele há a relação com outros enunciados que têm um vínculo com o passado e que se projetam para o futuro. Como o texto é o próprio contexto, a apreciação (resposta valorativa) é sempre uma reapreciação em um novo contexto.

O sentido é potencialmente infinito, mas pode atualizar-se somente em
contato com outro sentido (do outro), ainda que seja com uma pergunta do
discurso interior do sujeito da compreensão. Ele deve sempre contatar com
outro sentido para revelar os novos elementos da sua perenidade (como a
palavra revela os significados somente no contexto). Um sentido atual não
pertence a um (só) sentido mas tão-somente a dois sentidos que se
encontraram e se contactaram. Não pode haver "sentido em si" - ele só
existe para outro sentido, isto é, só existe com ele. Não pode haver um
sentido único (um). Por isso não pode haver o primeiro nem o último
sentido, ele está sempre situado entre os sentidos, é um elo na cadeia dos
sentidos, a única que pode existir realmente em sua totalidade. (BAKHTIN,
2003, p.382)

Os sentidos se constroem na relação também das fronteiras entre o tempo e o espaço. Ao pensarmos na obra, os sentidos se revelam atuais porque estão presentes no interior dela, ao mesmo tempo estão relacionados aos sentidos do contexto extraverbal, o que os fazem ganhar características novas quando interpretados e avaliados.

\footnotetext{
${ }^{51}$ A interpretação faz parte do processo da compreensão bem como a avaliação que se constituem como ato único e integral do processo dialógico.
} 
Os contextos mudam em relação aos momentos de observação, permitindo a atualização dos sentidos. São contextos que estão no nível do grande e do pequeno tempo. Quanto ao primeiro, a compreensão envolve contextos distantes cujos sentidos referem-se à produção histórica e cultural do homem: pelos séculos e milênios. O grande tempo inclui o diálogo infinito e inacabável, pois os sentidos estão sempre vivos.

[...] não há limites para o contexto dialógico (este se estende ao passado sem limites e ao futuro sem limites). Nem os sentidos do passado, isto é, nascidos no diálogo dos séculos passados, podem jamais ser estáveis (concluídos, acabados de uma vez por todas): eles sempre irão mudar (renovando-se) no processo de desenvolvimento subseqüente, futuro do diálogo. Em qualquer momento do desenvolvimento do diálogo existem massas imensas e ilimitadas de sentidos esquecidos, mas em determinados momentos do sucessivo desenvolvimento do diálogo, em seu curso, tais sentidos serão relembrados e reviverão em forma renovada. (em novo contexto) [...] (BAKHTIN, 2003, p.410, grifos do autor).

O outro, o pequeno tempo, representa os sentidos da atualidade que se estabelece pela relação do passado imediato e do futuro previsível.

Além do tempo, os sentidos se atualizam porque o movimento dialógico da interpretação envolve também a questão do espaço. Bakhtin reforça que o texto se constitui por sujeitos que ocupam posição ativa e responsiva diante do que ouvem, lêem e observam. A posição representa o espaço no movimento dialógico, assim a compreensão que gera os pontos de vista dos sujeitos recebe influência também do lugar que estão posicionados.

Numa situação qualquer ou até mesmo de proximidade em que o eu contempla o outro, sua visão está diferentemente focada devido à posição que se situa, o que o eu vê o outro não pode ver e vice-versa.

Há sempre um excedente de visão que se condiciona pelo lugar único que cada sujeito ocupa num conjunto de circunstâncias particulares. Como destaca: "[...] eu e os outros nos movemos em diferentes planos de visão e juízo de valor [...]" (BAKHTIN, 2003, p.54, grifos do autor).

Os diferentes planos de visão geram pontos de vista distintos entre os sujeitos, assim um mesmo acontecimento pode ser percebido de formas diversas. Machado (1995, p.37), ao estudar a questão do espaço na obra de Bakhtin, complementa que 
"[...] o ponto de vista único não implica unicidade de configuração, pois o olhar que um indivíduo dirige ao mundo cria uma simultaneidade de percepções [...]" que sempre estabelecem uma relação de complementaridade.

Quando relacionamos as categorias do eu e do outro a pontos de vista, entendemos que no diálogo os pontos de vista não se fundem, eles se completam. Cada sujeito tem sua própria visão sobre o acontecimento assim pode ver e saber o que o outro não vê e não sabe a partir da posição que ocupa.

A questão do tempo-espaço é importante porque todo texto que se cria é um algo a mais na cadeia discursiva, exatamente porque o autor traz pontos de vista que diferem de outros, pois se localiza em um outro lugar que o distancia do outro.

Quando pensamos no jornal, cada texto dará a sua contribuição para a compreensão dos fatos exatamente porque o autor de uma coluna, de um artigo ou de uma reportagem tece seu ponto de vista a partir da posição que ocupa em relação à situação da realidade.

A distância leva os sujeitos à compreensão do outro e à compreensão de sua cultura:

\begin{abstract}
A cultura do outro só se revela com plenitude e profundidade (mas não em toda a plenitude, porque virão outras culturas que a verão e compreenderão ainda mais) aos olhos de outra cultura. Um sentido só revela as suas profundidades encontrando-se e contactando com outro, com o sentido do outro: entre eles começa uma espécie de diálogo que supera o fechamento e unilateralidade desses sentidos, dessas culturas. Colocamos para a cultura do outro novas questões que ela mesma não se colocava; nela procuramos resposta a essas questões, e a cultura do outro nos responde, revelando-nos novos aspectos, novas profundidades de sentido. Sem levantar nossas questões não podemos compreender nada do outro de modo criativo [...] (BAKHTIN, 2003, p.366, grifos do autor)
\end{abstract}

A distância espacial e temporal nos leva à compreensão de outros enunciados de modo que possamos atribuir sentidos e contribuir com novos sentidos, com respostas atualizadas. 


\section{Capítulo 4 - Leitura dos textos de Clarice Lispector escritos para o Caderno B do Jornal do Brasil}

O procedimento metodológico desta pesquisa ocorreu em cinco fases:

Na primeira fase, foi realizada a leitura do Jornal do Brasil, entre os anos de 1967 a 1973, de modo que pudéssemos nos familiarizar com o jornal e, desse modo, contatar os textos de Clarice Lispector publicados aos sábados, no Caderno B, no próprio contexto para o qual eles foram escritos. A leitura, assim realizada, foi importante uma vez que nos aproximamos dos acontecimentos da época, inclusive da vida cotidiana do Rio de Janeiro.

$\mathrm{Na}$ segunda fase, priorizamos conhecer o trabalho de Clarice Lispector realizado para o JB nas edições do período mencionado. Estudamos o material diretamente no acervo da Biblioteca John Kennedy ${ }^{52}$ em São Paulo.

A terceira fase iniciou-se com visita à Biblioteca Nacional do Rio de Janeiro e demos continuidade à leitura do JB. Pelas páginas do jornal foi possível obter informações sobre os acontecimentos da época assim como a data precisa em que eles aconteceram e o espaço gráfico no qual eles foram apresentados. Desta forma, pudemos estabelecer relações entre os textos por ela produzidos, isto é, a coluna de Clarice no Caderno B e o contexto em que eles se construíram.

Nesta fase dedicamo-nos a estudar o conteúdo temático apresentado nos textos de Clarice Lispector com os demais textos que compunham o jornal. Foi necessário muito tempo dedicado para a leitura direta em todo material consultado.

Em decorrência disso, pudemos constatar que somente na relação dialógica entre os mais variados textos jornalísticos e os textos jornalísticos e os textos da coluna, é que poderíamos compreender os de Clarice Lispector e a contribuição de seu trabalho para o Jornal do Brasil.

$\mathrm{Na}$ quarta fase, selecionamos os textos exemplares, que são representativos do conjunto de textos escritos para o Caderno B no período de 1967 a 1969. Esses

\footnotetext{
${ }^{52}$ Algum tempo depois, o acervo dos jornais desta biblioteca foi transferido para a Biblioteca Mário de Andrade que aguarda o término das reformas para disponibilizá-lo ao público. As edições do jornal não eram microfilmadas.
} 
textos compõem quatro colunas publicadas em momentos diferentes: duas colunas foram publicadas em 1967; uma em 1968 e outra em 1969, uma vez que Clarice Lispector escreveu durante o período político da história brasileira marcado pelo regime militar pós-64 e pós o Ato Institucional n. ${ }^{\circ 5}$, decretado em dezembro de 1968 , período este em que a imprensa estava sob rígida censura.

Selecionamos esses textos pelos seguintes critérios: por mostrar correspondência entre os acontecimentos sócio-políticos e o tema tratado; pela construção composicional que varia conforme o período em que os textos foram escritos.

A quinta e última fase tratou da leitura dos textos exemplares apoiada na concepção de Mikhail Bakhtin de enunciado concreto e em suas peculiaridades constitutivas, o que incluiu o estudo do estilo, do conteúdo temático, da construção composicional dos textos e dos gêneros discursivos, conceitos apresentados no capítulo três deste trabalho. Incluímos referências tanto das obras originais do pensador russo como de seus intérpretes. Assim sendo, a escolha teórica se justifica porque nos possibilitou um estudo vertical desses textos.

Durante o trabalho de leitura dos textos, optamos em manter a grafia original, com isso alguns acentos, que outrora eram utilizados em algumas palavras e que hoje se encontram em desuso, estão aqui mantidos nos trechos que extraímos e que redigimos em itálico, mantendo assim a fidelidade do registro, este que se perde nas publicações dos livros. 


\title{
Clarice Lispector
}

\author{
prece por um padre
}

Vina noite gngicjei tema prece por un pe. dre que tem médo de morrer e tem nergonia Le ter meldo- Eu disse um pohoo para Dew3, com algum pudor: altyie a alva do Paíre $X$..., fase com que tle sinta vue Tua molo entd dada d dele, fase con que tie sinta que a morte nâo eriste porgati na verdade fo eatamos nd etervidade, frove com que cle sixta que amar 6 indo morrer, quie a entrega de st meamo nầ afgnifica a marte, fase com que ele sinta uma alegria modesta e aidrio, faes com que ble näo $\mathrm{Ta}$ mdague demais, porque a resposta serin too misteriosa quanito a perguntm, fase bom que the se lembre de que tambèm năo ad explicochio porqise um thino quer o beilo de sua míe e no extanto die quer e no entanto o Deijo 4 perieito, faze com que lle receba o misndo sem misco, pois para lase mundo tricompreensicel nó fomas criatlos e nós meamos tambeim incompreeneiveta, entajo 6 que ha tuma conerilo entre dsse misterio do mundo e o nowso, mas

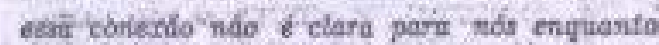
gutaermpe entende-iq, abencoe-0 pane que die

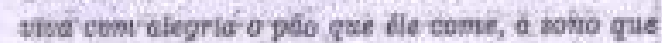
Ee dorme, fase com que fie tenha caridade por si mesmo; pois sendo ndo podeni aentir qus Dews o anowe fane com que ele perca o pudor de desejar que na hoirs da ma morte tle tenha tuma mâ hwmang pana apertar a sad, amém. (Podre X... tisha me pedido para eu rezar por ele).

\section{nầo sentir}

O hábito femilhe amortectido as quedas. Mas sentindo mesos dor, perdeu a senfapem de dor como aviso e rintama. Hoje em dia vive incompardicimente mais sereno, porim $\mathrm{cm}$ groxde perigo de vidar pode extar a win paseo de estar morrendo, a wn passo de jo ter morrido, e eem o beneficio de sen próprio avio prèvio. 


\section{ir para}

Exta notte um goto chorow fonto que tise tome das mail profundes compoisdes pelo gase $d$ vieo. Parecia tior, $t$, em nomas férmos hamanos e enimails, enc, Mas seris for, ot sta "ir", "ir pant"? Poin o que 6 vino nal para.

\section{daqui a vinte é cinco anos}

Perpinataramene ume ves de ex saberia outeilar o. Enast dequi a tinte e epros anos. vem daput a vinte e cinco minutos, quanto mali vinite e cinco anes. Nat a inpressab-denjo ti a de que wum futaro náo maito remoto thlset tomprepramoz que es mostmentos cadfices afanis ja erem of primeires passos ath.

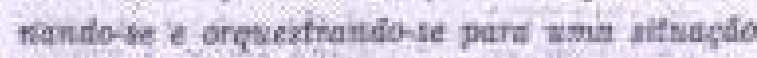
nconómica mais digne de twm homem, de unta mither, de wme crienpa. $\boldsymbol{E}$ tas porgue o povo fí fem dudo mostras de ter maier maturidade polities do que a grande mataria dos polificar. - Equar van dia terminard tiderando or liseror. Dequi e trite $t$ efnco anos a poso tend foTado muito mais.

Mes se vato sei prever, pono pelo menos desejar, Poaso intensamente desejer que o probleme mail urgente $2 e$ resolus o da fome. Multissimo mais degrean, porkm, do que em tivite e einco enor, perque ndo hit mair tempo de experar: milharer de homens, mulheres a crianças sdo verdadetros moribuhdos ambution. tes que tenticanente deviom astar internados

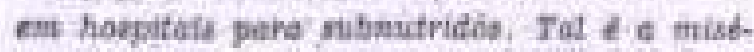
rifi, que de fustoficuria ter decrefado estado de prantidus, eomia diante de celianidode patbisca. 80 que é piar; a fome $e$ a nobia endemia, fit este fasendo partie orydulea do corpo $e$ da alme. $\boldsymbol{E}$, na maioria das -vésen, quartio se descresem as carecteristicas firlcas, morais $t$ mentas de um brasileirs, nde se note que nu ver. Aade is estido descrevendo or shintomats firicos, marals e mentais är fome. Ot liderrs gur ti-

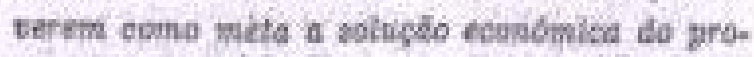
blema de comida serdo táo abencostor por nds como, em compiaragdo, a muxido esençoend os quie sescebriven a curid do concer. 
4.1 Coluna Clarice Lispector, publicada em 16 de setembro de $1967^{53}$.

\section{Prece por um padre}

Prece é um texto que se caracteriza pela relação de distanciamento hierárquico entre o enunciador e o interlocutor ao qual ele se dirige. Uma súplica que comunica um pedido com o objetivo de obter uma graça divina, um acontecimento necessário, porém impossível de ser concedido por um ser humano comum. É com esta finalidade que o enunciador ${ }^{54}$ a utiliza, mais exatamente para pedir a Deus uma dádiva. Ao lermos o final da prece, identificamos o enunciado-chave ${ }^{55}$ : "(Padre $X \ldots$ tinha me pedido para eu rezar por êle)" e que assim o consideramos porque é a partir dele que ocorre o desdobramento de outros enunciados que constituem a significação geral do texto. Salientamos também que este enunciado vem marcado pelos sinais de parênteses que o isolam dos demais e indicam que é uma passagem que se desvia da seqüência lógica da prece organizada pelo enunciador, mas que mesmo isolada não deixa de ser parte integrante desta: o deslocamento do enunciado com o uso dos parênteses revela a motivação que levou o enunciador a elaborá-la, isto é, como sendo um pedido do Padre $X$, um conjunto de enunciados que só se justifica pela impossibilidade momentânea do locutor legítimo.

A construção deste texto está organizada com enunciados da esfera religiosa, no caso a prece, que é uma manifestação discursiva utilizada em situações de dificuldade, de desespero, um modo de o ser humano se comunicar com o plano espiritual. Esses enunciados são incorporados e reacentuados ao texto e passam a gerar novos sentidos, como veremos no decorrer da leitura.

Antes de enunciar a prece, há uma confissão da falta de hábito de verbalizar este tipo de texto:

\footnotetext{
${ }^{53}$ Ver texto publicado no Caderno $\mathrm{B}$ à página 2 no anexo $\mathrm{B}$

${ }^{54}$ Escolhemos o termo "enunciador" para nos referirmos ao autor-criador, considerado por Bakhtin como o sujeito dotado de autoridade, isto é, aquele que possui posição valorativa e que em resposta a outros enunciados cria o seu enunciado.

${ }^{55}$ Consideramos enunciado-chave a idéia central a partir da qual o texto ganha desdobramentos. Esta parece ser uma marca recorrente do estilo de Clarice Lispector nos textos jornalísticos escritos para a coluna do Caderno B.
} 
"Uma noite gaguejei uma prece por um padre que tem mêdo de morrer e tem vergonha de ter mêdo."

O enunciador, em primeira pessoa do singular eu, expõe sua dificuldade em enunciar "uma prece por um padre", manifestada pelo verbo "gaguejei" o que nos leva a compreender que o pedido não se faz simples, pois o padre é um dos representantes oficiais da igreja e com a qual está unido pela fé e não tem o direito humano de ter emoções de medo e vergonha.

Depois prossegue:

"Eu disse um pouco para Deus, com algum pudor: alivia a alma do Padre X...,[...] "

Aqui, "Eu disse", na esfera da religião, conduz ao sentido da palavra rezar, assim como um ato religioso: eu rezei um pouco para Deus com "algum pudor", isto é, com modéstia já que está se dirigindo ao Ser Supremo sem se sentir no direito de fazê-lo, porém o faz por solidariedade humana: "alivia a alma do Padre $X . .,[\ldots]$ ". Neste trecho, pede para atenuar "a alma do Padre X", aliviar o sofrimento, concedendo-lhe algumas dádivas, que são enunciadas sequencialmente, separadas apenas por vírgulas, o que permite marcar o ritmo próprio de uma prece. Vejamos:

"faze com que êle sinta que Tua mão está dada à dêle, [...]"

Pede que lhe conceda segurança, um sentimento impossível na época porque havia um clima de violência. Existiam perseguições e torturas contra aqueles que se opunham ao regime militar. $E$ isso não foi diferente com os padres ${ }^{56}$. Como a

\footnotetext{
${ }^{56}$ Em 1962, após a primeira sessão do Concílio do Vaticano e diante das novas correntes do pensamento católico tanto europeu quanto latino-americano, os bispos brasileiros iniciaram uma mudança em seus discursos, posicionamentos políticos e na estrutura organizacional. Estavam abertos à Teologia da Libertação, "em que fé e política se tornavam termos indissociáveis e praticamente intercambiáveis" (MONTES, 2002, p.79). Com o golpe militar, em 1964, desmoronaram as esperanças dos cidadãos que lutavam para conduzir o país à democracia. Segundo Almeida e Weis (2002), ainda que o autoritarismo reprimisse a atividade política dos grupos opositores, estes resistiram e passaram a atuar clandestinamente durante todo o regime autoritário. A oposição era constituída da classe média intelectualizada como estudantes politicamente ativos, professores universitários, profissionais liberais, artistas, jornalistas. Havia também os setores oposicionistas, para citar apenas alguns, os políticos profissionais do Movimento Democrático Brasileiro (MDB), sindicatos, populares de um modo geral e a Igreja (da alta hierarquia até as pastorais e comunidades de base).
} 
sensação de insegurança aumentava a cada dia, pedia-se ajuda à instância Superior, quando enuncia "sinta que Tua mão está dada à dêle", além de que a mão de Deus representa o poder divino e proteção, já que no cotidiano não havia segurança e proteção. E continua:

"faze com que ele sinta que a morte não existe porque na verdade já estamos na eternidade, [...]".

O enunciador coloca-se na posição de nós (do pronome pessoal da primeira pessoa do plural) que indica que não apenas ele (padre) vive a eternidade, mas que todos nós "estamos na eternidade", ser eterno é nosso destino, segundo um princípio da religiosidade comum em nossa cultura.

"faze com que ele sinta que amar é não morrer, que a entrega de si mesmo não significa a morte, faze com que êle sinta uma alegria modesta e diária, faze com que êle não Te indague demais, porque a resposta seria tão misteriosa quanto a pergunta, faze com que êle se lembre de que também não há explicação porque um filho quer o beijo de sua mãe e no entanto êle quer e no entanto o beijo é perfeito, $[\ldots] "$

A morte está implícita no ato de viver, no entanto naquele momento histórico brasileiro, especialmente, a morte permanecia sem explicações lógicas. Outros atos humanos são inexplicáveis como o desejo de ser beijado, a necessidade do afeto para enfrentar o inexorável cotidiano.

Assim, padres, como D. Paulo Evaristo Arns, empenharam-se na luta contra as prisões e torturas dos oposicionistas, pela liberdade de expressão e contra a injustiça social. As denúncias sobre as prisões e os espancamentos de estudantes presos pelo DOPS foi informada na notícia "Medicina defende verbas em Goiás com uma greve", datada em 7 de mar. de 1967 (ver anexo C). Os estudantes dominicanos também participavam da luta pela melhoria da educação juntamente com os demais, tinham presença na UNE e saíam às ruas para protestar, como informava a notícia, datada em 16 de fevereiro de 1968 e publicada à página 11 do primeiro caderno, sobre o protesto em relação aos pagamentos de anuidades. Eles também se engajaram à militância, por exemplo, pela ALN (Aliança Libertadora Nacional). Mais tarde, já no período pós AI-5, em 8 de nov. de 1969, uma outra notícia vem confirmar a participação de representantes da Igreja na luta contra o Estado autoritário e que eram perseguidos. Na primeira página, a manchete anunciava: "Polícia gaúcha garante que seminário abriga subversão" (ver anexo D). Esta informava que o DOPS havia revistado o seminário à procura de frei Beto e acrescenta: " No Rio, o provincial dos dominicanos estêve ontem, vindo de São Paulo, com os membros da Ordem que residem no convento do leme. Frei Domingues veio em seu próprio carro e retornou horas depois a São Paulo, demorando-se pouco com seus companheiros. O silêncio na área religiosa é total, enquanto informava-se que o Núncio Apostólico vem mantendo o Papa a par dos acontecimentos no Brasil". 
"faze com que êle receba o mundo sem mêdo, pois para êsse mundo incompreensível nós fomos criados e nós mesmos também incompreensíveis, então, é que há uma conexão entre êsse mistério do mundo e o nosso, mas essa conexão não é clara para nós enquanto quisermos entendê-la, [...]"

O mundo que o enunciador faz referência é o espaço que se vivencia e também o que transcende e que está acima da nossa capacidade de compreensão.

Nesse trecho, o enunciador posiciona-se como nós (como sujeito coletivo) porque a sensação de medo diante dos acontecimentos de perseguição e até outros sentimentos que angustiavam os cidadãos era um "tema comum, do pensamento comum", Bakhtin (2003, p.320), é sensação do outro e de si mesmo, isto é, de todos aqueles que vivenciam os mesmos acontecimentos. $E$ para finalizar:

"abençoa-o para que êle viva com alegria o pão que êle come, o sono que êle dorme, faze com que êle tenha caridade por si mesmo, pois senão não poderá sentir que Deus o amou, faze com que êle perca o pudor de desejar que na hora da sua morte êle tenha uma mão humana para apertar a sua, amém."

A prece é uma forma discursiva utilizada para nos dirigirmos a Deus, ou a um ser Superior e não humano. A criação do enunciador-autor se estabelece na fronteira do espaço e do tempo: num momento anterior se realizou como um ato particular, como uma reza por um padre, o que fica evidenciado no enunciado: "uma noite gaguejei uma prece [...]". Num momento posterior, ao ser publicada na coluna do jornal, a prece ganha outros contornos porque torna-se um ato público, deslocase para a esfera jornalística. Na fronteira entre um gênero e outro, a prece escrita no jornal perde o vínculo imediato com a realidade concreta passando a integrar a realidade pelo conjunto da coluna, desta forma a prece como gênero discursivo primário ganha um caráter renovado no jornal. Passa a ser um acontecimento narrado pelo enunciador-autor da coluna; antes, uma forma típica utilizada para comunicar-se com Deus, como uma súplica particular; agora, ganha status de prece pública que comunica não apenas o dilema de uma única pessoa, mas o dilema da realidade natural do homem: o da vida e o da morte. A forma como os enunciados estão organizados permite ampliar a discussão sobre os valores mais humanos 
como o medo, a dor e a fragilidade humana, temas recorrentes na vida urbana brasileira da época, presentes nas páginas da imprensa.

A palavra morrer estabelece a interação entre este enunciado e o próximo: não sentir. Os pontos de vista se constroem na fronteira entre o viver e o morrer.

\section{Não sentir}

Neste enunciado, segue o tema sobre a morte em analogia ao não sentir:

"O hábito tem-Ihe amortecido as quedas. Mas sentindo menos dor, perdeu a vantagem da dor como aviso e sintoma. Hoje em dia vive incomparavelmente mais sereno, porém em grande perigo de vida: pode estar a um passo de estar morrendo, a um passo de já ter morrido, e sem o benefício de seu próprio aviso prévio".

Dá-se continuidade ao processo de denúncia velada da atmosfera que permeava a vida dos cidadãos naquele momento. "Não sentir" era um ato de defesa psicológica diante das situações vividas diariamente: "hábito tem-Ihe amortecido as quedas". Interessante notar que a palavra "amortecido" possui base morfológica morte-, assim o hábito coloca-o em estado quase morto, aquele que não sente dor diante das perdas que podem estar relacionadas à repressão, às torturas, à falta de esperanças, entre outras possíveis.

\section{Ir para}

No diálogo que trava com o leitor, trata da compaixão por um ser vivo:

"Esta noite um gato chorou tanto que tive uma das mais profundas compaixões pelo que é vivo. Parecia dor, e, em nossos têrmos humanos e animais, era. Mas seria dor, ou era "ir", "ir para"? Pois o que é vivo vai para" 
O enunciado marcado pela primeira pessoa do singular eu revela que a consciência de que "estar vivo" é uma necessidade humana diante do clima de insegurança $^{57}$

Mais adiante quando o enunciado é marcado pela conjunção mas confronta uma dúvida: era dor "ou era 'ir', 'ir para'?" As aspas colocadas no verbo ir no infinitivo bem como no verbo ir seguido da preposição para indicam que ambos estão sendo tomados em segundo sentido, se o verbo ir indica a ação de mover-se, entre aspas representa o oposto o de não poder se mover, que representa a situação do momento, o ato de ir e vir do brasileiro estava cerceado.

\section{Daqui a vinte e cinco anos}

O enunciado-chave é apresentado no final: "Os líderes que tiverem como meta a solução econômica do problema da comida serão tão abençoados por nós como, em comparação, o mundo abençoará os que descobrirem a cura do câncer". A partir deste enunciado, outros pontos de vista se desenvolvem. Quando faz referência à "solução econômica do problema da comida" estabelece-se relação com o contexto extraverbal da época, mais exatamente, sobre a questão econômica do país com o qual este enunciado se constrói para assim podermos compreender o que o enunciador quer comunicar.

Durante o ano de 1967, o país passava por problemas econômicos sérios, eram constantes as notícias sobre o aumento do custo de vida. Para trazer apenas um exemplo, na edição do dia 17 de setembro (ver anexo E), o jornal informava que o gasto mensal de um sanduíche, um refresco e um cafezinho representavam mensalmente 35\% do salário mínimo: "sem dinheiro para ir a um restaurante, os cariocas são obrigados a freqüentar lanchonetes e braseiros, onde as refeições são insuficientes e só aparentemente mais baratas" (JORNAL DO BRASIL, 1967). Essa e outras notícias, inclusive sobre a inflação eram constantes nas páginas do jornal.

\footnotetext{
${ }^{57}$ Embora não possamos comprovar com documentos, estes textos escritos por Clarice Lispector no jornal absorvem em sua linguagem, na construção composicional e nos temas selecionados a atmosfera de medo, insegurança do dia a dia do brasileiro.
} 
Diante dos problemas econômicos atuais da época, o enunciador acredita que serão "abençoados por todos nós", os líderes que estabelecerem meta para solucioná-los. A benção se fará por "todos nós", referindo-se a todos os cidadãos brasileiros, já que o enunciador, ao utilizar o pronome da primeira pessoa do plural nós, se inclui nessa tarefa como sujeito-cidadão que vivencia os problemas econômicos.

Destacamos também que pela palavra "meta", o enunciador organiza todos os seus enunciados no confronto entre os acontecimentos do presente que por ele são observados, vivenciados e denunciados e as propostas de mudanças futuras. Este enunciado-chave é uma resposta dada a uma pergunta, ao enunciado antecedente que se encontra relatado logo no início desta leitura:

"Perguntaram-me uma vez se eu saberia calcular o Brasil daqui a vinte e cinco anos. Nem daqui a vinte e cinco minutos, quanto mais vinte e cinco anos"

Como toda pergunta antecipa uma resposta, espera-se aqui uma previsão do enunciador, sua atitude responsiva. Na impossibilidade de fazer uma avaliação sobre o país dali a 25 anos ou 25 minutos, propõe então dar sua "impressão-desejo":

"Mas a impressão-desejo é a de que num futuro não muito remoto talvez compreendamos que os movimentos caóticos atuais já eram os primeiros passos afinando-se e orquestrando-se para uma situação econômica mais digna de um homem, de uma mulher, de uma criança. E isso porque o povo já tem dado mostras de ter maior maturidade política do que a grande maioria dos políticos, e é quem um dia terminará liderando os líderes."

O uso da conjunção mas demonstra a posição adversa do enunciador: se não pode "calcular o Brasil" pode dar a sua impressão-desejo. Este termo unido pelo hífen representa, ao mesmo tempo, o presente (situação atual da época) e o futuro, o que se espera. Ao aproximar seu olhar para a situação atual retrata-a como sendo a de "movimentos caóticos", impressão esta que extrai da realidade como observador e desse posicionamento projeta seu olhar como se estivesse no futuro, mais exatamente, distancia-se e desloca-se para outro tempo. Em: "os movimentos caóticos atuais já eram os primeiros passos", o uso do pretérito "eram" desloca para 
o passado o que ainda é atual (presente), tal recurso é utilizado pelo enunciador de modo a dar destaque a sua resposta axiológica que se dará pelo movimento dialógico da interpretação (BAKHTIN, 2003): o retrospectivo referente ao acontecimento passado (como aqui está posto) e o prospectivo, que antecipa o futuro, o desejado, mesmo que o deslocamento temporal aqui seja um ato criativo do enunciador e não um acontecimento real.

A interpretação permite considerar os movimentos caóticos como os primeiros ajustes, representados pelo uso das metáforas "afinando-se" e "orquestrando-se" para se transformarem numa "situação econômica mais digna". O desejo, como ação ainda não realizada, se constrói no diálogo que se estabelece com o outro. Para Bakhtin (2003, p.316), "a compreensão é sempre dialógica", assim compreender que a situação não é digna, é um ponto de vista partilhado entre outros sujeitos, como quando diz: "talvez compreendamos", estes que são os cidadãos, o "povo" que tem mostrado "ter mais maturidade política do que a grande maioria dos políticos".

Assim, estabelece-se um confronto entre enunciados. Na fronteira entre um e outro e entre "impressão-desejo", o enunciador faz uma crítica contundente em relação à conjuntura política e econômica instalada no país. Vejamos nos enunciados que seguem:

"[...] Daqui a vinte e cinco anos o povo terá falado muito mais".

O desejo declarado de que o "povo terá falado muito mais" traz outros enunciados implícitos, que estão relacionados à sua impressão: o povo não fala ou não pode falar (haja vista a situação política da época).

"Mas se não sei prever, posso pelo menos desejar. Posso intensamente desejar que o problema mais urgente se resolva: o da fome. Muitíssimo mais depressa, porém, do que em vinte e cinco anos, porque não há mais tempo para esperar: milhares de homens, mulheres e crianças são verdadeiros moribundos ambulantes que tècnicamente (sic) deviam estar internados em hospitais para subnutridos".

A solução do problema da fome é um desejo manifesto e a partir da interação com a realidade extraverbal constrói sua impressão, a de que o povo passa fome, ou 
melhor, de que "milhares de homens, mulheres e crianças são verdadeiros moribundos ambulantes". A intencionalidade do enunciador é polemizar o tema, fazer uma denúncia sobre o problema social da fome bem como o da miséria, fatos compartilhados pelos co-participantes da situação cotidiana. Deste modo, a partir das imagens captadas do dia-a-dia enfatiza que:

"Tal é a miséria, que se justificaria ser decretado estado de prontidão, como diante de calamidade pública. Só que é pior: a fome é a nossa endemia, já está fazendo parte orgânica do corpo e da alma.[...]".

Diante do que se vê, compara a miséria à "calamidade pública" considerando que as autoridades deveriam agir com rapidez porque a miséria é um grande mal que acomete muitas pessoas. O problema da fome é endêmico, isto é, "nossa endemia", um problema constante que afeta a população, fisicamente e espiritualmente. E continua:

“E, na maioria das vêzes, quando se descrevem as características físicas, morais e mentais de um brasileiro, não se nota que na verdade se estão descrevendo os sintomas físicos, morais e mentais da fome".

Este enunciado se constrói como resposta a outros enunciados, isso se constata claramente a partir dos verbos "se descrevem" e "se estão descrevendo", de modo a rejeitar os pontos de vista que tratam dos aspectos físicos, morais e mentais do brasileiro, pois para o enunciador a descrição física, moral e mental feita do brasileiro é, na verdade, os sintomas da fome.

O tema fome não era tratado no jornal. Interessante acrescentar, como exemplo, uma notícia publicada no primeiro caderno, em 17 de setembro, sobre os mendigos da cidade do Rio de Janeiro. A matéria, intitulada Maior parte dos mendigos recolhidos são falsos, bêbados e doentes mentais (ver anexo F), informava o resultado de uma pesquisa feita pela Secretaria de Serviços Sociais com os 340 mendigos recolhidos nos meses de junho e julho. A pesquisa foi justificada pela necessidade do encaminhamento dessas pessoas para os devidos centros de recuperação da cidade e revelou ainda que dos 340 mendigos recolhidos apenas 57\% não possuíam mão-de-obra especializada, 25\% tinham qualificação e 
18\% exerciam atividades diversas, principalmente no campo (JORNAL DO BRASIL, 1967, p.5). Mas nada diziam sobre a questão da fome e da miséria.

Assim, a previsão do futuro é um pretexto para falar do Brasil da época, na verdade, trata-se de um recurso estilístico utilizado pelo enunciador-autor que desloca a própria situação presente como desejo futuro.

Ao final da leitura, consideramos que a compaixão é a idéia que liga os enunciados. A compaixão é a dor sentida pelo mal alheio e este sentimento está presente nas questões da fome, da injustiça social, comiseração por aqueles que sofrem com o medo da morte, da dor que não se quer sentir ou simplesmente por estar vivo. 


\section{Clarice Lispector}

\section{Mêdo do desconhecido}

Entбo isso era a felicidade. E por assim dizer sem motivo. De início se sentiu vazia. Depois os olhos ficaram úmidos: era felicidade, mas como sou mortal, como o amor pelo mundo me transcende. O amor pelo vida mortal a assassinava docemente, aos poucos. E a que é que eu faço? Que faço da folicidade? Que faço dessa paz estranha e aguda, que já está começando a me doer como uma angústía, como um grande silêncio? A quem dou minha felicidade, que já está começando a me rasgar um pouco e me assusta. Nāo, nāo queto ser feliz. Prefiro a mediocridade. Ah, milhares de pessoas nấo têm coragem de pelo menos prolangar-se um pouco mais nessa coisa desconhecido que a sentir-se feliz, e preferem a mediocridade.

\section{Dos palavróes no teatro}

Eu própria nảo uso palavióses porque na minha casa, na infância, năo usavam e habituei-me a me exprimir através de outro linguajar. Mas o palaviăo - aquêle que expressa o que uma palavra nảo faria - ésse náo me choca. Há peças de teatro, como A Volta ao Lar (Fernanda Montenegro, excelente) ou Dois. Perdidos numa Noite Suja (Fauzi Arap a Nélson Xavier, excelentes), que simplesmente năo poderiam passar sem ○ palavrão por causa do ambiente em que se passam e pelo tipo dos personagens. Essas duas peças, por exemplo, sáo de alta qualidade, e nāo podem ser restringidas.

Além do mais, quem vai ao teatro em geral jă está pelo menos ligeiramente informado, por rumóres aft́, da espécie de espetáculo a que assistirá. Se o palavrăo lhe dá mal-estar ou o escandalixa, por que entáo comprar a entrada?

E. mais ainda: as pecas de teatro têm censura de idade, e o mais comum 6 só permitir a entrada de menores a partir de dezesseis anos, o que é uma garantia. Embora mesmo antes dessa idade os palavrōes sojam conhecidos, e' usados pela maioria da juventude moderna.

Qual é ontāo o problema que o uso do palavrăo adequado a um texto poderia suscitar? E sem falar que, agrade ou näo, o palavräo fax parte da lingua portuguêsa. 


\section{Chacrinha?!}

De tanto falarem en Chacrinha, liguei a te: levisaso para seu programa que me pareceu durer mais que uma hore.

E fiquei pasma. Dizen-me que esse programa te atualmente o mals popular, Mas como? $O$ homem tem qualquer colsa de doido, e estou usando a palavra doide no seu verdadeiro sentido. O auditório tamben cheio. E um programa de calouros, pelo menos o que eu vi. Ocupa a chamada hora nobre da televiska. O homem se veste com roupas loucas, o calouro apresenta o seu número e, se nāo agrada, a buzina do Chacrinha funciopa, despedindo-o. Alem do mais, Chacrinhe tem algo de sádleor sente-se ó prazer que tem em usar a buzina. E suas gracinhas se repetem a todo o instante - falta-lhe imaginaçio ou ale e obcecado.

E os calouros? Como e deprimente. Saso de tcdas as idades. E em todas as idades ve-se a ansia de aparecer, de se mostrar, de se tornar fomoso, mesmo a cusla do ridiculo ou de humilhaçao, Vêm vethos ate de setenta anos. Con excecóes, os calouros, que sūo de origem humilde, têm ar de subnutridos. E o auditorio aplaude. Ha pre. mios en dinheiro para os que acertarem atraves de cartas o número de buzinadas que Chacrinha darb; polo menos fol assim no programa que vi. Será pala possibilidade da sorte de ganhar dinhelro, como em loterio, que o programa tem tal popularidade? Ou serb por pobreza de espirito de ncsso povo? Ou será que os telespectadores tem em. si um pouco de sadismo que se compraz no sadismo de Chacrinha?

Nobo entendo. Nossa televisiso, com exce. Coss, e pobre, alom de superlotada de anúncios, Mas Chacrinha foi demais. Simplesmente nibo en1endi of fenomeno. E fiquel Iriste, decepcionodar eu quereria um povo mais exigente. 
4. 2 Coluna Clarice Lispector, publicada em 7 de outubro de $1967^{58}$.

\section{Medo do desconhecido}

O enunciado-chave: "Ah, milhares de pessoas não têm coragem de pelo menos prolongar-se um pouco mais nessa coisa desconhecida que é sentir-se feliz, e preferem a mediocridade" representa o ponto essencial da reflexão do enunciador, este que se coloca na posição do eu (primeira pessoa do singular) sempre na relação com o outro (milhares de pessoas que compartilham os mesmos sentimentos), preferindo a mediocridade à felicidade. Tal compreensão é apenas uma fase inicial que prepara para as respostas que sucedem:

" Então isso era a felicidade. E por assim dizer sem motivo.[...]"

Este enunciado complementa outro sentido atribuído à felicidade: é um estar feliz sem razão de ser. E descreve o momento em que a felicidade aconteceu:

"De início se sentiu vazia. Depois os olhos ficaram úmidos: era a felicidade, mas como sou mortal, como o amor pelo mundo me transcende. O amor pela vida mortal a assassinava docemente, aos poucos. [...]"

O enunciado, "o amor pelo mundo me transcende", se constrói nas relações entre o eu e o outro, nas fronteiras temporais e espaciais, mesmo se existirem diferenças entre elas. Já a felicidade em si, sem motivo, pode ser considerada uma auto-sensação primitiva natural em que "o eu e o outro estão fundidos" (BAKHTIN, 2003, p.383), porque o pensamente abstrato faz desaparecer as fronteiras, é um estado sentido por mim e que aos poucos acaba. Além disso, há outros sentidos atribuídos à felicidade, apresentados nas perguntas que seguem:

"E o que é que eu faço? Que faço da felicidade? Que faço dessa paz estranha e aguda, que já está começando a doer como uma angústia, como um grande

\footnotetext{
${ }^{58}$ Ver texto publicado no Caderno $B$ à página 2 no anexo $G$
} 
silêncio? A quem dou minha felicidade, que já está começando a me rasgar um pouco e me assusta. Não, não quero ser feliz. Prefiro a mediocridade."

As perguntas demonstram a intensidade do que é estar ou ser feliz. Ao indagar "que faço da felicidade", expõe outros sentidos: a da paz estranha e aguda que dói como angústia, como um grande silêncio. O sentido, para Bakhtin (2003, p.382), responde sempre a certas perguntas e se atualiza em contato com outro sentido (do outro) mesmo "que seja com uma pergunta do discurso interior do sujeito da compreensão". Assim os sentidos aqui atribuídos estabelecem ligação com os do outro (de milhares de pessoas) e dessa interação resulta a preferência pela mediocridade, um estado comum ao invés do sentir-se feliz, que exige a coragem das pessoas.

É possível que o enunciador tenha captado o clima da época, afinal os menos informados e menos sensíveis, quase medíocres, estariam felizes na sua inocente desinformação, pois aqueles que são conscientes sofrem mais.

\section{Dos palavrões no teatro}

O enunciado-chave, "Qual é então o problema que o uso do palavrão adequado a um texto poderia suscitar? E sem falar que, agrade ou não, o palavrão faz parte da língua portuguesa", é o ponto estratégico para compreendermos o posicionamento do enunciador na questão dos palavrões do teatro, tema logo anunciado no título. A pergunta não se caracteriza como um simples ato de questionar porque carrega toda a indignação do enunciador diante do acontecimento. Isso é possível verificar na escolha que faz da palavra então, de uso enfático, expressa um tom provocativo que incita os interlocutores a pensar sobre o tema: que não era o uso do "palavrão em si", mas a censura que reprimia uma forma de expressão ${ }^{59}$. Diante do problema exposto, constrói a seguinte argumentação:

\footnotetext{
${ }^{59}$ É importante destacar que desde o golpe militar até 1968, antes do decreto do Ato Institucional n.5, a ordem autoritária não tinha regras claras, eram cambiantes porque não havia limites definidos entre o proibido e o permitido. Para Almeida e Weis (2002, p.328), apesar de os dois primeiros presidentes militares, Castello Branco e Costa e Silva, terem concedido "razoável liberdade de movimento às oposições", poderia ser considerado como atitudes oposicionistas: participar de assembléias e
} 
"Eu própria não uso palavrões porque na minha casa, na infância, não usavam e habituei-me a me exprimir através de outro linguajar. [...]"

Ainda que seja apresentada a experiência pessoal do enunciador quando enuncia em primeira pessoa: "Eu própria não uso palavrões" reforça que o ato de não usar palavrões se dá por hábito: "habituei-me a me exprimir através de outro linguajar" e não por escolha, desta forma, este enunciado confronta outros enunciados, rejeita aqueles que consideram o palavrão como algo ofensivo e não o rejeita por uma questão de costume. Entretanto, não é a experiência pessoal do enunciador que ganha destaque, mas a censura imposta pelo regime militar ao teatro ${ }^{60}$.

Ao enunciar: "[...] Mas o palavrão - aquêle que expressa o que uma palavra não faria - êsse não me choca" constrói o enunciado como resposta a outros enunciados, diante daqueles que consideram o palavrão como algo censurável. $O$ uso da palavra mas é um recurso verbal utilizado para introduzir os pontos de vista do enunciador que se constroem na relação com o outro (participantes da vida cultural do teatro e também de outros participantes possíveis) e que se opõe à ação da censura:

"[...] Há peças de teatro, como A Volta ao Lar (Fernanda Montenegro, excelente) ou Dois Perdidos numa Noite Suja (Fauzi Arap e Nélson Xavier, excelentes), que simplesmente não poderiam passar sem o palavrão por causa do ambiente em que se passam e pelo tipo de personagens. Essas duas peças, por exemplo, são de alta qualidade e não podem ser restringidas."

manifestações públicas, escrever artigos, criar músicas, romances, peças de teatro, fazer chegar à imprensa denúncias de tortura, etc. "Dadas as características do regime, qualquer desses atos envolvia riscos pessoais impossíveis de ser avaliados de antemão. Daí as incertezas quanto às conseqüências da ação [...] a insegurança e, inevitavelmente, o medo terem sido sensações básicas, cotidianas e comuns a quem quer que tenha feito oposição à ditadura."

${ }^{60}$ Como já apresentamos no capítulo um, o teatro foi considerado um inimigo do regime militar, assim os artistas sofriam várias perseguições, inclusive de algumas pessoas que iam ao teatro para agredilos verbalmente. Vale lembrar que existiam cidadãos que pertenciam aos grupos mais conservadores da sociedade que defendiam a moral e os bons costumes. 
Ao mesmo tempo em que julga o mérito das duas peças de teatros, o enunciador expõe crítica à censura imposta a elas: "são de alta qualidade e não podem ser restringidas". Este enunciado deve ser visto diretamente como resposta aos atos de censura impostos ao teatro que são aqui denunciados ${ }^{61}$. O teatro foi alvo de repressão de ordem moral e esse fato não era abordado pelas notícias do jornal.

Além disso, o enunciador denuncia a censura, antecipa o acontecimento na esfera jornalística e seu enunciado passa a estabelecer relação também com outros enunciados, àqueles "que o antecedem e o sucedem" (BAKHTIN, 2003, p.371). Algum tempo depois a esta publicação, outros enunciados se construíram com a mesma temática, como exemplo, a notícia publicada no dia 19 de março no primeiro caderno com o título "Artistas voltam às ruas em movimento contra a censura", que tratou do protesto realizado no Rio pelos profissionais de teatro (JORNAL DO BRASIL, 1968, p.14) e no dia 30 de março, Yan Michalski (JORNAL DO BRASIL, 1968, p.4) escreveu para o Caderno B sobre o problema da censura e as divergências entre artistas de teatro e censores. (ver anexo $\mathrm{H}$ )

Em seguida, constrói outro argumento de modo a fortalecer posição em favor do palavrão no teatro:

"Além do mais, quem vai ao teatro em geral já está pelo menos ligeiramente informado, por rumôres até, da espécie de espetáculo a que assistirá. Se o palavrão Ihe dá mal-estar ou o encandaliza, por que então comprar a entrada?"

Pelo uso da expressão "além do mais", acrescenta seu estranhamento diante daqueles que vão ao teatro mesmo já sabendo da classificação do espetáculo enfatizado pela pergunta formulada posteriormente: "Se o palavrão Ihe dá mal-estar

\footnotetext{
${ }^{61}$ Mais tarde, no mesmo caderno $\mathrm{B}$, a enunciadora Clarice Lispector voltou a tratar sobre a censura imposta às peças de teatro. No dia 19 de outubro de 1968, em sua coluna intitulada São Paulo, integrou ao seu texto a carta de Fernanda Montenegro denunciando a censura. Extraímos este trecho: " Clarice

é com emoção que the escrevo pois tudo o que você propõe tem sempre essa explosão dolorosa. É uma angústia terrivelmente feminina, dolorosa, abafada, educada, desesperada e guardada. Ao ler meu nome, escrito por você, recebi um choque não por vaidade mas por comunhão. Ando muito deprimida, o que não é comum. Atualmente em São Paulo se representa de arma no bolso. Polícia nas portas dos teatros. Telefonemas ameaçam o terror para cada um de nós em nossas casas de gente de teatro. É o nosso mundo. [...]

Fernanda".
} 
ou o escandaliza, por que então comprar a entrada?" É importante destacar que há novamente o uso enfático da palavra então, que agrega o tom provocativo que faz ao interlocutor. E para finalizar, apresenta o último argumento:

"E mais ainda: as peças de teatro têm censura de idade, e o mais comum é só permitir a entrada de menores a partir de dezesseis anos, o que é uma garantia. Embora mesmo antes dessa idade os palavrões sejam conhecidos e usados pela maioria da juventude moderna".

Acrescido "E mais ainda", o enunciador observa que há uma recomendação de classificação etária indicativa para as peças de teatro como para outras produções artísticas. E sugere ainda que elas sejam recomendadas a partir de dezesseis anos, apesar de os palavrões já serem conhecidos e usados por eles. Considerando o uso da palavra embora, o enunciador contrapõe o argumento de que os palavrões pertencem também aos hábitos modernos da juventude, o que não deveria suscitar censura.

E se não é uma questão de censura, o teatro não poderia sofrer restrições porque o palavrão pertence à língua portuguesa. O argumento que se constrói demonstra que não havia critérios definidos para a censura, o que de fato podia ser permitido ou proibido.

\section{Chacrinha?!}

O enunciado-chave que destacamos, "Não entendo. Nossa televisão, com exceções, é pobre, além de superlotada de anúncios. Mas Chacrinha foi demais. Simplesmente não entendi o fenômeno. E fiquei triste, decepcionada: eu quereria um povo mais exigente", é o ponto da crítica que o enunciador faz em relação à censura que não impedia as manifestações burlescas do programa do Chacrinha que nada acrescentavam para a cultura brasileira. A crítica já se inicia no título: "Chacrinha?!" pela marca de pontuação dos sinais de interrogação e exclamação utilizados juntos, que instaura os sentidos de dúvida e ao mesmo tempo perplexidade. Isso porque os responsáveis pela censura liberam um programa 
televisivo de banalidades e reprovam as peças de teatro $A$ Volta ao Lar e Dois Perdidos numa Noite Suja, o que reforça novamente a falta de critérios em relação a ação da censura.

Então, na posição de crítico, o enunciador em primeira pessoa do singular eu passa a descrever seu primeiro contato e as impressões que delas extrai. A construção estilístico-composicional ocorre por meio de respostas sempre dadas a enunciados anteriores e por perguntas criadas pelo enunciador:

"De tanto falarem em Chacrinha, liguei a televisão para seu programa que pareceu durar mais de uma hora."

O enunciado "liguei a televisão para seu programa que pareceu durar mais de uma hora" se constrói como resposta a outro enunciado anterior: "De tanto falarem em chacrinha [...]", este diz respeito aos comentários de outros sujeitos (daqueles que assistem ao programa). A avaliação inicia-se nesse momento, quando o enunciador trata da duração do programa: "pareceu-me durar mais que uma hora", o que pelo verbo "pareceu-me" deixa implícito de que para ele o programa dava a impressão de prolongar mais, indicando tédio e reprovação. E acrescenta:

"E fiquei pasma. Dizem-me que êsse programa é atualmente o mais popular. Mas como?"

A perplexidade do enunciador em: "fiquei pasma" é a resposta para o outro enunciado pertencente a conversas do cotidiano: "Dizem-me que êsse programa é atualmente o mais popular" porque envolve a apreciação do enunciador diante daquilo que viu e diante do que dizem de modo a não considerar verdadeira a informação sobre ser esse o programa o mais popular. "Mas como? (como pode ser popular?). A pergunta formulada pelo enunciador é um ponto importante por expressar sua posição valorativa em relação ao programa e ao próprio Chacrinha. Vejamos:

"[...] O homem tem qualquer coisa de doido, e estou usando a palavra doido no seu verdadeiro sentido. [...]" 
A palavra doido não é apenas utilizada no sentido literal, mas indica a posição axiológica do enunciador diante de sua relação com o mundo, da relação com o programa que é considerado um fenômeno de audiência pelos outros sujeitos, isto porque "um observador não tem posição fora do mundo observado, e sua observação integra como componente o objeto observado"(BAKHTIN, 2003, p.332, grifo do autor). Assim, é importante notar que a expressão doido está colocada em destaque para dar ênfase à posição tomada pelo enunciador. Depois:

"O auditório também cheio. É um programa de calouros, pelo menos o que eu vi. Ocupa a chamada hora nobre na televisão. O homem se veste com roupas loucas, o calouro apresenta o seu número e, se não agrada, a buzina do Chacrinha funciona, despedindo-o. Além do mais, Chacrinha tem algo de sádico: sente-se o prazer que tem em usar a buzina. E suas gracinhas se repetem a todo instante - falta-lhe imaginação ou êle é obcecado."

A expressão "calouros" também está em destaque bem como o termo "hora nobre", porque a perplexidade do enunciador se constrói a partir de outros detalhes do programa e que serão avaliados posteriormente. Quanto à outra expressão hora nobre - o destaque imprime um sentido implícito, o de que o programa não se qualifica para tal horário, pois desde o início de sua avaliação e das outras que sucedem, a qualidade é colocada em dúvida. E continua:

"E os calouros? Como é deprimente. São de tôdas as idades. E em tôdas as idades vê-se a ânsia de aparecer, de se mostrar, de se tornar famoso, mesmo à custa do ridículo ou da humilhação. [...]"

O estilo de lançar uma pergunta: "E os calouros?" permite apresentar seus pontos de vista e mostrar o aspecto deprimente que os envolve: "de tôdas as idades" e sem exceção, "vê-se a ânsia de aparecer, de se mostrar e de se tornar famoso mesmo à custa do ridículo ou da humilhação". O desejo da visibilidade, de ser notado e de se tornar célebre faz com que cada um deles exponha-se à zombaria e à submissão, não correspondendo a nenhum ato distinto, isto é nobre como o horário em que o programa passa: "hora nobre". E continua: 
"Vêm velhos até de setenta anos. Com exceções, os calouros, que são de origem humilde, têm ar de subnutridos. E o auditório aplaude.[...]"

Os calouros de "origem humilde" têm aspecto "de subnutridos", aqui expõe o problema da falta de alimentação do povo que também tem "ânsia de aparecer, de se mostrar, de se tornar famoso" pela televisão, mas o que é pior: "o auditório aplaude", aclama não o calouro, mas o que é "ridículo". Estes enunciados, por estabelecerem inter-relação com aqueles enunciados que dizem respeito à popularidade do programa, revelam que o popular tem ligação com os valores de sadismo e de humilhação ${ }^{62}$. E diante disso, levanta muitas outras questões:

"Há prêmios em dinheiro para os que acertarem através de cartas o número de buzinadas que Chacrinha dará; pelo menos foi assim no programa que vi. Será pela possibilidade da sorte de ganhar dinheiro, como em loteria, que o programa tem tal popularidade? Ou será por pobreza de espírito de nosso povo? Ou será que os telespectadores têm em si um pouco de sadismo que se compraz no sadismo de chacrinha?"

O estilo questionador impõe as incertezas diante da popularidade que dizem que esse programa tem. Se o programa do Chacrinha é considerado como fenômeno, as questões visam demonstrar os sentidos diversos atribuídos àquilo que é extraordinário para os calouros que têm "pobreza de espírito"(os outros) não o é para o enunciador que se opõe a essa opinião. Também não se identifica com os pontos de vista dos telespectadores (os outros) que são tão sádicos como Chacrinha $^{63}$. Seu texto integra outros pontos de vista que circulam na esfera do

\footnotetext{
${ }^{62}$ A crítica que faz ao programa é também um modo de expor as mazelas do país, uma acentuada desigualdade social que já se acentuava nesse momento, resultado do desenvolvimento capitalista implementado pelas reformas do regime militar e de usar a nossa miséria e nossos miseráveis como entretenimento. Ao mesmo tempo faz crítica ao programa como espetáculo que de acordo com Sodré e Paiva (2002, p.16), ao estudarem a estética do grotesco, consideram o programa do Chacrinha como uma "exibição irrisória de pequenas aberrações humanas e de gente do povo seduzida por prêmios banais e pequenos instantes de visibilidade pública".

${ }^{63}$ É importante acrescentar que na visão de Sodré e Paiva (2002, p.115), o auditório recria, de forma espontânea, as festas e os espetáculos públicos, isto é, assume parte da tensão presente vividas pelas classes economicamente subalternas no espaço urbano e, ao mesmo tempo, manipula os conteúdos 'popularescos' de modo a atender a competição comercial e publicitária pelo mercado da audiência.
} 
diálogo do cotidiano e passa a reelaborá-los em forma de crítica que publica no jornal para denunciar a exploração humana como entretenimento.

Com a leitura desta coluna, é possível dizer que as temáticas têm como ponto em comum a questão da mediocridade, que permeia os sentimentos e as ações do homem, como a censura que, num ato medíocre, julga as produções de teatro pelo uso dos palavrões quando estes se constituem registros da fala natural das personagens da peça e, ao mesmo tempo, permite manifestações grotescas do programa do Chacrinha. Essas manifestações acabam expondo a exploração cruel das diferenças humanas, a miséria e a falta de solidariedade com o único intuito de conseguir audiência. 


\section{Clarice Lispector}

\section{Carla ao Ministro da Educaçāo}

Em primoiro lugar queriamos saber so as verbas destinadas para a Educaciño sto distribuldas pelo senhor. Se niso, ests carta deveria se dirigir ao Presidente da República. A Aste näo me dírijo por uma esplecie de puder, encuanto sinto-me com mais direito de falar com - Ministro da Educacío por If ter sido estudante.

O senhor há de estra. nhar que uma simples escrilora escrova sobre um asuunto tsa complexo como o de verbas para edu. cagto - o que no caso significa abrir vages para os excedentes, Mas o problema 6 tho gravo e por vâres pafólico que mesmo a mim, nito tendo ainda filhos em idade unl. versildria, me toca.
Na verdade eu näo finha diroito a vaga.

Náo estou do modo al. gum entrando em seara alheia. Fsta seara de do fodos nob. E estou falando em nome de tanios que, simbolicamente, dé como se o senhor chegase a janela de seu gabinate de trabalho e visse embsixo uma multidho de rapares - mócas esperando seu veredfthum.

Ser estudante alge" muito scrio. E quando os ideals se formam, b quando mails se pensa num meico de aludar a Bratil. Senhor Ministro ou Prestdenfe da República, impedir quo fovens entrem em universidades 6 um crime. Pardoe a vialdencia da palavra. Mas da palavra certa. 
O MEC, visando avitar - problema do grande número de candidatos pare poucas vagas, resolveu fazer constar nos oditais de vositibular que os concursos seriam classiticatorios, considerando aprovados apenas os primeiros colocados dentro do número de vagas existentes. Esta medida impede qualquer açäo judicial por parte dos que nấo sifo aproveitados, nấo impedindo no entando que os alunos tenham o impulso de ir as ruas para reivindicar as vagas que thes stio negadas.

Senhor Ministro ou sonhor Prosidonte: "excedentes" num pais que ainda esth om construçăo?l e que precisa com urgéncia de homens a mulheres $q u 0$ o construam? 56 deixar antrar nas Faculdades os que tirarem melhores notas ef fugir completamente ao problema. $O$ senhor ia foi estudante sabe que nem sempre on alunos que tiram as melhores notas lorminam sendo os meThores profissionalis, os mais capacitados para resolverem na vida real os grandes problemas que existem. E nem sempre quem tire as melhores nolas e ocupa uma vaga lem pleno diroito a ela. Eu mesme fui universitiria o no vestibular classificaram-me entre os primeiros candidatos No ontanto, por motivos que aqui nẫo importam, nem sequer segui a profisstio.
Se a verba pare universidades of curta, obrigando a diminuir o número de vagas, por que nāo. submotem os estudantes, alguns meses antes do vestibular, a exames psicotécnicos, a testes vacaclionais? lsso nấo só serviria de eliminatória para as facuidades, como ajudaria sos estudantes que estivessem em caminho errado do vocactio. Euta ideia partiu de uma estudante.

Se o senhor soubesse do sacrificio que na maioria das vitzes a familia inteira fax para que um rapax realixe o seu sonho, o de estudar. Se soubesse da profunda e multas vazes irreparível desilusāo quando entra a palavra "excedente". Falei co m uma jovem que fol excedente, porguntei-the como se semtira. Respondeu que de repente se sentira desorientada a vaxia, enquanto so seu lado rapares a maças, ao se saberem oxceedentes, all mesmo comecaram a chorar. E nem poderiam sair a rua para uma passeata de protesto porque sabem que a policis poderia espanch-los.

O senhor sabo o prego dos livros para próvestibulares? Silo carissimos, comprados a $c u \leqslant t a$ de grandes dificuldades, pagos em prestaçbes. Para no fim terem sido Inūheis?

Que entas päginas simbolizem uma passeata de protesto de rapazes = móças. 
4.3 Coluna Clarice Lispector, publicada em 17 de fevereiro de $1968 .^{64}$

\section{Carta ao Ministro da Educação}

O título do texto prenuncia a forma do gênero discursivo escolhido pelo enunciador. Ao enunciar "Carta ao Ministro da Educação" estabelece com os interlocutores a forma como pretende enunciar o tema, que se dará por meio de uma carta aberta. A escolha por esse gênero discursivo se dá pela intenção do enunciador em querer se manifestar publicamente contra a decisão do Ministério da Educação e Cultura (MEC). Sua intencionalidade está marcada no enunciado-chave: "Que estas páginas simbolizem uma passeata de protesto de rapazes e môças". Para atender a esse objetivo, endereça a carta ${ }^{65}$ a um interlocutor determinado, o próprio Ministro da Educação e Cultura Tarso Dutra. Logo no primeiro parágrafo desta, tem-se a confirmação de que é ele, e não outro, o destinatário. Vejamos:

“Em primeiro lugar queríamos saber se as verbas destinadas para a Educação são distribuídas pelo senhor. Se não, esta carta deveria se dirigir ao Presidente da República. A este não me dirijo por uma espécie de pudor, enquanto sinto-me com mais direito de falar com o Ministro da Educação por já ter sido estudante"

No enunciado acima, reforça-se o destinatário como sendo o ministro por dois motivos: 1) aquele a quem se deve dirigir quando o assunto tratado é sobre "as verbas destinadas para a educação"; 2) pela justificativa de o enunciador "já ter sido estudante", autorizando-o a se dirigir primeiramente ao Ministro. Vale destacar que

\footnotetext{
${ }^{64}$ Ver texto publicado à página 2 do Caderno $\mathrm{B}$ no anexo I

${ }^{65}$ Segundo Bakhtin (2003, p.282), "a vontade discursiva do falante se realiza antes de tudo na escolha de um certo gênero de discurso. Essa escolha é determinada pela especificidade de um dado campo da comunicação discursiva, por considerações semântico-objetais (temáticas), pela situação concreta da comunicação discursiva, pela composição pessoal dos seus participantes, etc." (grifos do autor). Considerando a temática abordada que envolve a questão das verbas para educação e que o destinatário é o Ministro da Educação e Cultura, autoridade legítima que responde por essa área, a escolha da carta é a forma encontrada pelo enunciador para encaminhar um protesto. É importante ressaltar que na esfera jornalística, a carta aberta é a forma relativamente estável e típica de construção elaborada quando há a necessidade de se dirigir publicamente a alguém pela coluna de um jornal. Brait (2005, p.89) acrescenta que "cada esfera conhece gêneros apropriados a suas especificidades".
} 
ele é o representante oficial do Ministério e, por esta função, está incumbido de responder pelos assuntos que dizem respeito à educação. Esta escolha não poderia ter sido diferente porque, de acordo com Bakhtin (2003, p.301), o aspecto e a concepção do destinatário são determinados pela esfera "da atividade humana e da vida a que tal enunciado se refere" e o enunciador, ao colocar-se na posição daquele que já fora estudante, toma a si mesmo como autoridade legítima para se dirigir ao ministro e não ao presidente.

Além de se colocar na posição do "eu" particular, o de "ter sido um estudante", o enunciador também fala em nome de outros enunciadores potenciais que representa. Na carta, "eu" (que já fora estudante no passado) passa a ser "nós" (estudantes). Como podemos observar em: "queríamos saber se as verbas destinadas para a Educação são distribuídas pelo senhor", o "nós" (pronome pessoal da primeira pessoa do plural) resulta da relação do "eu" (enunciador, sujeito particular e social) e do outro (vários sujeitos de enunciações implícitas). O "eu" é o sujeito que ao perceber o que se passa no cotidiano como acontecimento concreto, coloca-se no lugar do outro, dos estudantes, assumindo para si o que é assunto de todos nós (o eu, que já fora estudante, e os outros, estudantes), partindo, assim, dessa posição, sente-se no direito de escrever a carta para tratar das "verbas destinadas para a Educação". Entretanto, é importante destacar que o diálogo se constrói não por um sujeito que se funde ao outro como um ser uno, mas na fronteira entre o eu e outro. O "nós" representa, aqui, o encontro dessas idéias como resposta ao acontecimento.

Toda expressão do enunciador articulada e dirigida ao destinatário se constrói numa tomada de posição em favor do outro (os estudantes). Os pontos de vista do eu não são isolados, eles se constroem a partir do fato que é comum a todos os interlocutores e representam a avaliação que faz deste. Neste trecho:

"o senhor há de estranhar que uma simples escritora escreva sobre um assunto tão complexo como o de verbas para educação - o que no caso significa abrir vagas para os excedentes. Mas o problema é tão grave e por vêzes patético que mesmo a mim, não tendo ainda filhos em idade universitária, me toca"

O "eu", que ora se instituiu como aquele que fora estudante e agora também como "simples escritora" e como cidadã (que não tem filhos pré-universitários, o que 
a isenta de interesses particulares e ainda reforça o sujeito coletivo nela instaurado pela linguagem) inicia uma exposição avaliativa sobre a questão das "verbas para a educação". Seus pontos de vista são elaborados e reelaborados a partir do acontecimento e se constroem como resposta a este. A idéia de que "o problema é tão grave e por vezes patético" marca a posição do enunciador sobre a escassez de vagas para os estudantes e o comove porque não há vagas para todos.

O ponto exato que se propõe discutir é o problema dos excedentes, que é grave e patético. Grave porque não há vagas para os estudantes; patético, porque é tão somente uma questão de verbas, isto é, designar uma quantia de dinheiro para a educação.

A expressão excedentes está carregada de valor, pois estabelece relação dialógica com o enunciador, com a realidade imediata (situação extraverbal) e com outros enunciados e passa a revelar tanto os sentidos criados por ele como aqueles que lhe foram dados. Os pontos de vista do enunciador se confrontam com outros pontos de vista diferentes:

"O MEC, visando evitar o problema do grande número de candidatos para poucas vagas, resolveu fazer constar nos editais de vestibular que os concursos seriam classificatórios, considerando aprovados os primeiros colocados dentro do número de vagas existentes [...]"

As informações apresentadas remetem a um contexto extraverbal que retomamos no curso desta exposição porque integram o tema e a construção composicional $^{66}$. O período que antecede a escritura da carta foi marcado pelo movimento dos estudantes em busca da reforma universitária. Desde o início do ano de 1967, o tema referente à educação esteve em pauta. O Jornal do Brasil, por várias vezes, noticiou acontecimentos envolvendo os jovens estudantes e a difícil tarefa de conseguir vaga no ensino superior.

O JB, no dia 5 de março desse mesmo ano, lançara o caderno especial sobre Educação no Brasil que trazia, em suas seis páginas, informações referentes à

${ }^{66} \mathrm{O}$ contexto extraverbal compreende o horizonte espacial comum entre os interlocutores, o conhecimento e a compreensão comum da situação por eles compartilhada e a avaliação comum dessa situação. (BAKHTIN; VOLOSHINOV, s/d) 
expansão do ensino ginasial e médio e a necessidade de investimento maciço. Tratava também da falta de planejamento em relação às universidades.

Depois, no dia 7 de março, o editorial Coisas da Política, à página 6 do jornal, discutiu sobre o ensino e a crise educacional. As notícias da página 11 (anexo C) informavam que diante do encarecimento do custo de vida, que assolava o país, as famílias de classe média estavam transferindo seus filhos para o ensino público. $\mathrm{Na}$ busca de solucionar o problema, foi criado o terceiro turno para o nível primário e em outros estados chegaram a ter até cinco. Esses turnos existiam na tentativa de acomodar os 50.000 excedentes. No ensino superior, o número era bem mais reduzido, algumas centenas, mas isso não impedia que os universitários promovessem movimentos de protesto pelas ruas do Rio e de outras cidades brasileiras, como as de Minas Gerais de modo a reivindicar as vagas a que tinham direito.

É importante lembrar que, durante a década de 60 , os universitários participavam ativamente das questões educacionais e dos acontecimentos da vida nacional e lutavam por seus direitos e por reformas que trouxessem melhorias para a educação.

Ao longo dos anos de 1967 e 1968, a crise na educação e a questão da falta de vagas ganharam as páginas do jornal, incluindo as do Caderno $B$, o que vem a demonstrar que o texto de Clarice Lispector dialoga com estas comunicações da imprensa.

Em leitura às edições do Jornal do Brasil, pudemos identificar que a expressão excedentes era comumente usada para representar, à época, os estudantes do ensino primário e do superior, que apesar de terem o direito de estudar, tinham dificuldades em encontrar vagas na rede oficial.

Vale ressaltar também que naquele tempo os estudantes, que não se classificavam dentro do número de vagas existentes, embora aprovados, eram considerados excedentes, assim exigiam das autoridades a expansão das vagas. Como as exigências não eram atendidas, promoviam manifestações nas ruas e em frente às faculdades. Os excedentes organizavam-se em comissões a fim de que fossem realizadas assembléias para decidir a pauta de reivindicações. No final expediam nota com esclarecimentos à opinião pública noticiadas no jornal.

Todos os protestos estavam relacionados à Ordem oficial do MEC que fez "constar nos editais de vestibular que os concursos seriam classificatórios, 
considerando aprovados apenas os primeiros colocados dentro do número de vagas existentes". Estes enunciados pertencentes à esfera da educação são incorporados no interior da carta pelo enunciador e passam a estabelecer relação com seus enunciados particulares. Podemos perceber que os pontos de vista do enunciador, apresentados em seqüência, são respostas a esses enunciados antecedentes e com os quais polemiza:

"Esta medida impede qualquer ação judicial por parte dos que não são aproveitados, não impedindo no entanto que os alunos tenham o impulso de ir às ruas para reivindicar as vagas que Ihes são negadas".

O enunciador mantém uma posição adversa ao enunciado precedente articulada pela palavra "no entanto". A idéia, que aqui se expressa, reforça que a decisão do MEC não soluciona o problema de vagas e não impede que os movimentos de protestos continuem, isto é, que os estudantes saiam "às ruas para reivindicar as vagas que Ihes são negadas” ${ }^{\prime 67}$. A própria idéia, dita anteriormente, de que a questão de vagas para os excedentes é um problema grave, surge como resposta à medida imposta pelo MEC. Na correlação estabelecida entre os outros enunciados, a atitude responsiva do enunciador revela-se em tom de divergência em relação à medida e com o intuito de debater o tema, assim escolhe a expressão excedentes a fim de confrontar o destinatário abertamente:

“Senhor Ministro ou senhor Presidente: 'excedentes' num país que ainda está em construção?! e que precisa com urgência de homens e mulheres que o construam?"

Pelo uso do vocativo, interpela o Ministro ou o Presidente (pela própria integração de responsabilidades) a respeito dos excedentes. O primeiro

\footnotetext{
${ }^{67}$ Tanto é fato de que essas manifestações continuaram acontecendo nos meses seguintes. $O$ ano de 1968 foi marcado por muitos protestos e muita violência. O editorial do dia $1^{\circ}$ de abril desse ano (ver anexo J), intitulado Do protesto à desordem, traz à tona os conflitos pelos quais passava o país. Em crítica contundente sobre a educação brasileira expõe as deficiências do sistema educacional do país. Este texto foi escrito após a morte do estudante Edson Luís em 29 de março. Interessante observar que "o enunciado não está ligado apenas aos elos precedentes mas também ao subseqüentes da comunicação discursiva",Bakhtin (2003, p.301). Sendo assim, compreendemos que a visão do enunciador se coloca como análise dos acontecimentos anteriores e daqueles atuais dos quais foram considerados no momento da escritura da carta.
} 
questionamento: “ 'excedentes' num país que ainda está em construção?!”, além de pedir explicações para o fato, expõe, em tom exclamativo, a surpresa com que o enunciador toma o fato para si. A expressividade do enunciado, marcada pelo uso dos dois sinais juntos de interrogração e exclamação (?!) que tanto questiona como exclama, bem como o uso de excedentes entre aspas, manifesta um sentido de contradição em relação à situação concreta, a de que: o "país está em construção", e frente a isso não há porque considerar excedentes se o Brasil precisa de "homens e mulheres que o construam".

Os questionamentos formulados pelo enunciador põem em evidência a contradição de considerar os estudantes como excedentes, visto que os discursos que circulavam na esfera política enfocavam a necessidade de o país retomar o desenvolvimento econômico e incentivar a produção de profissionais mais qualificados $^{68}$. A medida instituída pelo MEC indicaria, então, a contradição entre o discurso da política econômica e o da política educacional manifestada pelo enunciador na construção dos enunciados que organiza.

Ainda defendendo a idéia inicial de que o problema sobre as "vagas para os excedentes" é "tão grave", reforça que:

"Só deixar entrar nas Faculdades os que tirarem melhores notas é fugir completamente ao problema."

Pelo sistema classificatório instituído, as notas determinavam a escala gradual dos resultados do concurso vestibular e os candidatos cuja classificação excedesse o número de vagas estimado não tinham direito de estudar. Se pensarmos que todos os excedentes tinham sido classificados, então, eles estavam habilitados e se qualificavam para o ensino superior e o único empecilho se dava em relação ao número insuficiente de vagas que não atendia a demanda de inscritos, o que nos remete à proposição do enunciador de que o assunto sobre "verbas para educação significa o abrir vagas para os excedentes".

O MEC, ao publicar que seriam "aprovados os primeiros colocados dentro do número de vagas existentes" não estaria, na visão do enunciador, resolvendo o

\footnotetext{
${ }^{68}$ Esta informação foi extraída do Caderno Especial sobre o tema: Educação no Brasil que circulou no domingo do dia 5 de março de 1967.
} 
problema, significava apenas "fugir completamente" dele. E para sustentar esta idéia, tece o seguinte plano argumentativo:

"O senhor já foi estudante e sabe que nem sempre os alunos que tiram as melhores notas terminam sendo os melhores profissionais, os mais capacitados para resolverem na vida real os grandes problemas que existem. E nem sempre quem tira as melhores notas e ocupa uma vaga tem pleno direito a ela."

Pelo recurso da conjunção nem, argumenta que não existe relação direta entre melhores notas e melhores profissionais: "nem sempre os alunos que tiram as melhores notas terminam sendo os melhores profissionais". No plano da materialidade lingüística, a conjunção escolhida na construção composicional do enunciado separa uma idéia da outra. A mesma idéia de exclusão é acrescentada a: "nem sempre quem tira as melhores notas e ocupa uma vaga tem pleno direito a ela". Assim enuncia que a escolha pelas melhores notas pode não ser, por fim, a melhor solução para o problema. Além desse recurso, faz uso de um exemplo pessoal como efeito de sentido a mais na formulação dos argumentos:

"Eu mesma fui universitária e no vestibular classificaram-me entre os primeiros candidatos. No entanto, por motivos que aqui não importam, nem sequer segui a profissão. Na verdade eu não tinha direito à vaga".

O enunciador, posicionado como eu, autoriza-se como modelo para confirmar que o verdadeiro direito à vaga não se relaciona àqueles cuja classificação está entre os primeiros colocados, isto é, entre os candidatos que obtiveram as melhores notas, pois, assim como ele, podem não seguir a profissão, ou nem se tornarem bons profissionais ou até capacitados a solucionarem problemas da vida real. O que é trazido aqui como experiência do enunciador ,enquanto pessoa, não está isolado do acontecimento (contexto extraverbal da realidade), porque sua experiência se correlaciona a outros enunciados antecedentes e a eles responde. A experiência pessoal relatada indica sua posição de discordância em relação aos demais enunciados que demonstram a posição dada pelo MEC sobre o direito à vaga. Segundo Bakhtin (2003, p.297), "é impossível alguém definir sua posição sem correlacioná-la com outras posições". 
É, então, nessa correlação, que o enunciador dá continuidade a seus argumentos. Vejamos o trecho:

"Não estou de modo algum entrando em seara alheia. Esta seara é de todos nós. E estou falando em nome de tantos que, simbolicamente, é como se o senhor chegasse à janela de seu gabinete de trabalho e visse embaixo uma multidão de rapazes e môças esperando seu veredictum."

O enunciador, ao se colocar novamente na posição "nós" (eu e outros), demonstra sua atitude em favor dos estudantes excedentes e confirma que não está entrando em seara alheia, ao contrário, pois considera que "esta seara é de todos nós", incluindo os leitores destinatários do presente e do futuro. E quando reforça que está "falando em nome de tantos" de uma multidão de rapazes e moças, evidencia a intencionalidade de ampliar seus discursos para além das fronteiras da esfera pessoal, incluindo aí a esfera coletiva. Isso ocorre porque até aquele momento, o Ministro da Educação, Tarso Dutra, não havia dado nenhuma resposta aos estudantes. O Jornal do Brasil noticiava sobre as manifestações dos estudantes que aguardavam a decisão do ministro para dar uma solução ao problema.

O veredicto não era aguardado só pelos estudantes, mas inclusive pelo enunciador que escreve a carta com o intuito de cobrar-lhe resposta em nome de todos eles, em alusão àqueles que saíram às ruas para reivindicar vagas e que aqui estão simbolizados pela "multidão de rapazes e môças" que aguardam uma resposta do ministro.

Mantendo posição contrária à do MEC, o enunciador expõe claramente sua opinião sobre o fato, de modo a criticar arduamente a posição adotada pelo ministério. Neste trecho:

"Ser estudante é algo muito sério. É quando os ideais se formam, é quando mais se pensa num meio de ajudar o Brasil. Senhor Ministro ou Presidente da República, impedir que jovens entrem em universidades é um crime. Perdoe a violência da palavra. Mas é a palavra certa."

A crítica do enunciador refere-se à posição do MEC de ter instituído o sistema classificatório na tentativa de "evitar o problema do grande número de candidatos 
para poucas vagas", pois considera o estudante um ser digno de consideração, além do que, ser estudante marca o período de sua formação, da formação de seu caráter e de sua mentalidade, bem como o momento que "mais se pensa num meio de ajudar o Brasil" ${ }^{\prime \prime 9}$, pois o país crescia e precisava de pessoas qualificadas. Se esse é o período em que "os ideais se formam", então, o ato que impede o estudante de estudar, é "crime". A escolha das palavras crime e violência não se dá aleatoriamente, mas pela própria assimilação do enunciador diante das situações cotidianas, como diria Bakhtin (2003, p. 294), como "ecos de outros enunciados". As manifestações estudantis ocorridas eram vistas por muitos como um movimento anarquista $^{70}$, além de serem reprimidas pelas autoridades governamentais já que a censura já havia sido instaurada pelo regime militar desde o golpe de 1964.

Na compreensão do enunciador, a decisão do MEC é vista como um ato de violação dos direitos dos estudantes por impedir que "jovens entrem em universidades" e por isso considera um crime. Este julgamento se constrói na relação com a situação dada, isto é, na interpretação que o enunciador (com sua experiência de já ter sido estudante, bem como na posição de cidadão que toma partido das questões que envolvem toda a sociedade) faz com outros enunciados. $\mathrm{O}$ confronto entre os enunciados dos outros e os seus próprios estabelece uma relação dialógica de discordância.

Como observador, integra, no interior de seu enunciado, outros enunciados pertencentes à réplica do diálogo cotidiano, que estão presentes no trecho que segue:

"Se a verba para universidades é curta, obrigando a diminuir o número de vagas, por que não submeterem os estudantes, alguns meses antes do vestibular, a exames psicotécnicos, a testes vocacionais? Isso não só serviria para as faculdades, como ajudaria aos estudantes que estivessem em caminho errado de vocação. Esta idéia partiu de uma estudante"

\footnotetext{
${ }^{69}$ Nesse período marcado pelo regime militar, as Forças Armadas estavam implementando as reformas para o desenvolvimento do capitalismo no país (BARROS,1999). O Rio de Janeiro vivia o boom do crescimento urbano com construções de prédios comerciais e residenciais. O jornal trazia diariamente a publicidade de grandes empresas do ramo de equipamentos, da engenharia, da construção e da arquitetura bem como as imagens dessas construções.

${ }^{70}$ Esta informação foi extraída da Nota expedida pelos excedentes em 7 de março de 1967 (ver Anexo $C$ ) e publicada no dia seguinte no JB, à página 11 do primeiro caderno.
} 
A idéia de sugerir exames psicotécnicos, testes vocacionais antes do concurso do vestibular é a resposta sugerida por uma estudante para o problema das vagas. O diálogo cotidiano se incorpora à carta e ganha sentido renovado porque os pontos de vista do eu e do outro estão posicionados num plano único e singular de visão em relação ao tema: de que o sistema classificatório instituído não é a solução mais adequada. O eu e o outro ficam num mesmo plano de visão quando, segundo Bakhtin (2003, p.54), "eu me coloco sob norma comum com os outros (na moral, no direito) ou sob uma lei cognitiva comum (fisiológica, psicológica, social, etc.). Neste caso, o enunciador também considera justa a escolha pelo critério de vocação e por este posicionamento pensa e vê como o outro. E se o destinatário (ministro) estivesse no mesmo plano de visão do enunciador e dos estudantes poderia posicionar-se de outra forma, daí o enunciado estar orientado desta maneira:

"Se o senhor soubesse do sacrifício que na maioria das vezes a família inteira faz para que um rapaz realize seu sonho, o de estudar. Se soubesse da profunda e muitas vezes irreparável desilusão quando entra a palavra 'excedente'. [...]

Com o uso do pretérito imperfeito do subjuntivo "se soubesse", há o desejo de transferir o destinatário, no caso o Ministro, para o plano comum do eu (enunciador que já foi estudante) e do outro (estudantes excedentes) para que pudesse pensar como eles e compreender o acontecimento sob outra perspectiva. Além desse recurso, o enunciador incorpora o enunciado de uma jovem estudante como forma de confrontar outros pontos de vista: "[...] Falei com uma jovem que foi excedente, perguntei-Ihe como se sentira. Respondeu que de repente se sentira desorientada e vazia, enquanto ao seu lado rapazes e môças, ao se saberem excedentes, ali mesmo começaram a chorar. [...]"

O enunciador também denuncia a repressão imposta às manifestações dos estudantes:

“[...] E nem poderiam sair à rua para uma passeata de protesto porque sabem que a polícia poderia espancá-los" 
Nessa época, todo o movimento de protesto era violentamente reprimido, não havia liberdade de expressão, apesar de o governo afirmar que se vivia numa democracia ${ }^{71}$.

Por último, volta a formular perguntas para também expor os problemas da crise econômica e social vivenciada naquele momento: "O senhor sabe o preço dos livros para pré-vestibulares? São caríssimos, comprados à custa de grandes dificuldades, pagos em prestações. Para no fim terem sido inúteis?"

É importante acrescentar que a carta traz em seu interior o excedente de visão do enunciador. Ele constrói seus pontos de vista a partir do lugar em que está posicionado o que permite completar os pontos de vista do outro.

A escolha do gênero carta possibilitou ao enunciador, na qualidade de cidadão participante ativo dos acontecimentos, apresentar seu protesto publicamente.

\footnotetext{
${ }^{71}$ No dia 16 de outubro de 1967, o Jornal do Brasil publica, em sua primeira página, a notícia com a seguinte manchete: "Presidente diz que o País vive em plena democracia e é necessário consolidála."
} 


\section{Clarice Lispector}

\section{MEDO DA LIBERTAÇ.ÃO}

Se eu me demorar demais olhando Paysage aux Oiseaux Jaunes (Paisagem com Pássaros Amarelos, de Klee), nunca mais poderei voltar atrás. Coragem e covardia sâa um joggo que se joga a cada instante. Assusta a visão talvez irremediável e que talvez seja a da liberdade. $O$ hábito que temos de olhar através das grades da prisáo, o confórto que traz segurar com as duas máos as barras frias de ferro. A covardia nos mata. Pois há aquéles para os quais a priséo $e$ a segurança, as barras um apoio para as mäos. Então reconheço que conheço poucos homens livres. Olho de nôvo a paisagem $e$ de nôvo reconheço que covardia e liberdade estiveram em jógo. A burguesia total cai ao se olhar Paysage aux Oiseaux Jaunes. Mitha coragem, inteiramente possivel, me amedronta. Começo até a pensar que entre os loucos há os que nä́o sấo loucos. $E$ que a possibilidade, a que é verdadeiramente, nāo é para ser explicada a um burgues quadrado. $E$ a medida que a pessod quiser explicar se enreda em palavras, poderá perder a coragem, estará perdendo a liberdade. Les Oiseaux Jaunes näo pede sequer que se o entenda: êsse grau é ainda mais liberdade: não ter médo de nấo ser compreendido. Othando a extrema beleza dos pássaros amarelos cal. culo o que seria se eu perdesse totalmente o médo. O confórto da prisäo burguesa tantas vezes me bate no rosto. $E$, antes de aprender a ser livre, tudo eu agientava - só para năo ser livre.

\section{Esbôço do sonho do lider}

O sono do líder é agitado. A mulher sacode-o até acorda-lo do pesadelo. Estremunhado, êle se levanta, bebe um pouco de água, vai ao banheiro onde se vé diante do espelho. $O$ que ve éle? Um homem de meiaidade. Ele alisa os cabelos das têmporas, volta a deitar-se. Adormece e a agitaçáo do mesmo sorho recomeça. "Nấ, nāo!", debate-se com a garganta sêca.

E que o lider se assusta enquanto dorme. 0 povo ameaça o lider? Nấ, pois se foi o povo que o elegeu como lider do povo. O povo ameaça o lider? Náo, pois escotheu-o no meio de lutas quase sangrentas, $O$ povo ameaça o lider? Nâ, porque o lider cuida do povo. Cuida do povo?

Sim, o povo ameaça o lider do povo. 0 lider revolve-se na cama. De noite éle tem médo. Mesmo que seja um pesadelo sem história. De noite vé caras quietas, uma atrás da outra. $E$ nenthuma expressão nas caras. E só éste o pesadelo, apenas tsso. Mas cada noite, mal adormece, mais caras quietas väo-se reunindo ds outras, como na fotografia em branco e prêto de uma multidáo em siléncio. Por quem é éste siléncio? Pelo líder. E uma sucessāo de caras iguais como numa repeticáo monótona de um rosto só. Parece uma terrivel fotomontagem onde $a$ inexpressäo das caras dá-lhe mếdo. Nesse painel monstruoso, caras sem expressä́o. Mas o lider se cobre de suores porque os milhares de olhos vazios näo pestanejavam. Eles o haviam escolhido. $E$ antes que éles enfim se aproximassem definitivamente, éle gritou: sim, eu menti! 
4.4 Coluna Clarice Lispector, publicada em 31 de maio de $1969 .^{72}$

\author{
Medo da libertação
}

Este texto é escrito no período em que a imprensa estava sob rígida censura, após ter sido decretado o Al-5. ${ }^{73}$ Sem liberdade de expressão, muito do que deveria ser publicado e dito, tornara-se proibido. Os jornalistas e colaboradores dos jornais precisavam escolher o modo de expressar seus pontos de vista sem que fossem considerados subversivos, caso contrário, eram perseguidos e presos. Assim era comum o uso de metáforas e de outros recursos para fugir ao corte dos censores ${ }^{74}$. Na verdade, a liberdade foi cerceada a todos os cidadãos e, sob pena de punição, nenhuma crítica contra o governo podia ser dita ou escrita publicamente. O Ato representou o fechamento do governo às oposições o que implicou a perda da liberdade, o endurecimento da censura, a exacerbação da violência repressiva contra grupos oposicionistas.

\footnotetext{
${ }^{72}$ Ver texto publicado à página 2 do Caderno $\mathrm{B}$ no anexo $\mathrm{K}$

${ }^{73}$ É preciso lembrar que nessa época o Ato Institucional n. ${ }^{5}$ já havia sido instituído pelo Presidente Costa e Silva e por todos os Ministros de Estado, mais exatamente no dia 13 de dezembro de 1968, juntamente com o Ato Complementar n. ${ }^{038}$ que decretou o recesso do Congresso Nacional, sem prazo determinado. Com o Al-5, houve a suspensão de muitos direitos, como o direito de votar e os direitos políticos, proibidas as atividades e as manifestações sobre assuntos de natureza política. A aplicação de medidas de segurança foi autorizada: liberdade vigiada, proibição de freqüentar determinados lugares, domicílio determinado. Além de que autorizava o Presidente da República a baixar Atos Complementares. Segundo Gaspari (2002, p.340-341), o artigo 10, que suspendia a garantia de Habeas corpus nos casos de crimes políticos contra a segurança nacional, era a pior das marcas ditatoriais do Al-5, porque "haveria de ferir toda uma geração de brasileiros [...]". Passados três dias da edição do Ato, "estabeleceu-se que os encarregados de inquéritos políticos podiam prender quaisquer cidadãos por sessenta dias, dez dos quais em regime de incomunicabilidade. Em termos práticos, esses prazos destinavam-se a favorecer o trabalho dos torturadores. [...] As emissoras de televisão, as rádios e as redações de jornais foram ocupadas por censores recrutados na polícia e na Escola de Aperfeiçoamento de Oficiais." Para Faro (1999, p.278), o Ato 5, fez com que o Estado militar recebesse "seu acabamento, não só pelo clima criado nas redações do jornal, mas pelo medo generalizado que se instalou na vida brasileira."
}

${ }^{74}$ Citamos um exemplo do próprio JB. Para denunciar que o jornal já estava sob censura, decidiu publicar na primeira página juntamente com o Ato Institucional n. 5 e o Ato Complementar n. ${ }^{\circ} 38$, a previsão do tempo (localizada à margem superior esquerda) da seguinte forma: "Tempo negro. Temperatura sufocante. O ar está irrespirável. O país está sendo varrido por fortes ventos. Máx.: 38, em Brasília. Min.: 50, nas Laranjeiras." No Canto superior direito: Ontem foi o Dia dos Cegos. (ver Anexo L). Assim, a previsão do tempo criada como notícia, parafraseando Traquina (2005a, p.203) deu "existência pública à problemática", ou seja, ao problema da censura. 
Este é o horizonte espacial comum presumido e compartilhado pelos cidadãos brasileiros e vivenciados coletivamente. Assim, o título: "Mêdo da libertação" remete ao contexto extraverbal compartilhado pelos cidadãos brasileiros sob dois aspectos: o clima de medo que se instalou na vida cotidiana da época e a perda da liberdade, isso pode ser reforçado pelo enunciado-chave: "O confôrto da prisão burguesa tantas vêzes me abate no rosto. E, antes de aprender a ser livre, tudo eu agüentava - só para não ser livre."

Assim, diante dessa situação, o enunciador constrói seu comentário, por meio de metáforas, e compartilha suas impressões com o leitor. Primeiro, estabelece um encontro com o quadro de Paul Klee ${ }^{75}$, "Paisagem com Pássaros Amarelos". Ao interagir com os elementos expressivos da obra, atribui à cena dos pássaros o sentido de estar livre, que contrasta com a realidade vivenciada: a perda da liberdade. Este sentido novo e atualizado $^{76}$ é o tema que se propõe comentar, mas como não pode fazê-lo abertamente por razões da repressão, elabora uma construção figurada, uma forma criativa para expressar seus pontos de vista:

"Se eu me demorar demais olhando Paysage aux Oiseaux Jaunes (Paisagem com Pássaros Amarelos, de Klee), nunca mais poderei voltar atrás. Coragem e covardia são um jôgo que se joga a cada instante. Assusta a visão talvez irremediável e que talvez seja a da liberdade.[...]"

Quando enuncia: "[...] Coragem e covardia são um jôgo que se joga a cada instante", a metáfora "jogo que se joga", utilizada pelo enunciador, permite fazer uma avaliação do cotidiano que se instituiu após a deliberação do Al-5, pois o enunciado destacado está marcado pelo verbo "são", conjugado no presente do indicativo, que

\footnotetext{
${ }^{75}$ Paul Klee (1879-1940) nasceu em Münchenbuchsel, perto de Berna na Suíça. Segundo Lagôa (2006), ele é considerado um dos grandes nomes da arte moderna, mesmo não se vinculando, exclusivamente, a nenhuma das correntes da vanguarda, estabelece estreitas relações com algumas de suas propostas. Ele compartilhava da necessidade de instituir as bases de uma nova arte, livre das convenções. A cor sempre foi um dos elementos mais importantes para o artista. No início de sua carreira lidava com as cores apenas sob uma perspectiva teórica, mais tarde, descobriu a qualidade emocional das cores. O quadro Paisagem com Pássaros Amarelos foi pintado em 1923(ver anexo M).

${ }^{76}$ Porque não se trata, como diz Machado (2005, p.162), "de transportar as formulações de uma área para a outra mas de reelaborar dialogicamente o pensamento." A interação com o quadro Paisagem com Pássaros Amarelos é o um dos pontos de contato dialógico necessário para a criação deste enunciado. Neste caso, representa uma das etapas "do movimento dialógico da interpretação: o ponto de partida - um dado texto, o movimento retrospectivo" (BAKHTIN, 2003, p. 401); a outra etapa, "o movimento prospectivo - antecipação (e início) do futuro contexto" que se dá na construção do comentário, a criação.
} 
representa os acontecimentos do momento com os quais dialoga. As palavras "coragem e covardia" revelam os pontos de vista diferentes que circulam no cotidiano e que se referem à questão da ditadura: às ações antagônicas impostas, aos discursos oficiais do governo, às ações de repressão por ele realizadas, mas não assumidas, à violência imposta contra os cidadãos.

Este embate de idéias está presente, como exemplo, na declaração do Presidente publicada no $J B$, no dia 28 de dezembro de 1968, à página 1, momento posterior ao decreto: "[...] o Presidente Costa e Silva disse que êste governo 'não almeja nem tolera a ditadura', 'mas usará a fôrça todas as vezes que a fôrça for necessária e útil aos interesses maiores da nacionalidade"'. Além disso, a mesma notícia traz as informações do Deputado Clóvis Stenzel, da Arena, sobre as punições das cassações. Segundo ele, elas atingiriam apenas a área da subversão, mas isso não era verdade, pois antes mesmo de ter sido decretado o Ato, muitos cidadãos já haviam sido presos, como jornalistas, estudantes, artistas e intelectuais ${ }^{77}$. A temática sobre as prisões se faz presente no comentário:

"O hábito que temos de olhar através das grades da prisão, o confôrto que traz de segurar com as duas mãos as barras frias de ferro. A covardia nos mata. Pois há aquêles para os quais a prisão é a segurança, as barras um apoio para as mãos. Então reconheço que conheço poucos homens livres.[...]"

A palavra "hábito" e as expressões metonímicas: "grades da prisão" e "barras frias de ferro" referem-se possivelmente a ação constante em que as prisões aconteciam. Utilizadas como um recurso estilístico do enunciador, estas expressões se fazem presentes pela impossibilidade de reportar explicitamente os acontecimentos dessa época. Esta forma de registro figurado é o modo de "representar e de simular [...] as visões de mundo que esses registros implicam" (BRAIT, 2004, p.142). Assim, cada expressão, cada signo, leva para além dos limites deste enunciado, isto é, a tudo que envolvia o cotidiano do Rio de Janeiro.

\footnotetext{
${ }^{77}$ Segundo Ventura (1988, p.287), "o Al-5 começou a censurar antes de ser editado e a prender antes de ser anunciado publicamente. Na quinta-feira à noite, véspera da decretação do ato, enquanto o marechal Costa e Silva se mantinha trancado no Laranjeiras vendo filme de banguebangue, ouvindo música clássica ou fazendo palavras cruzadas, os seus censores invadiam as redações dos jornais, rádios e televisão de vários Estados."
} 
Diante dos acontecimentos vivenciados, o enunciador constrói sua crítica e a faz na posição de também ser um cidadão, reforçado pelo uso do pronome pessoal nós: "A covardia nos mata". Também confronta as opiniões de outros cidadãos que consideram a ação repressora como um ato de coragem e até mesmo de segurança: "Pois há aquêles para os quais a prisão é a segurança, as barras um apoio para as mãos", mas que em sua visão é o próprio ato de covardia.

O ponto de vista do enunciador se constrói na relação com outros enunciados que circulavam no diálogo cotidiano e integravam os textos jornalísticos, por exemplo, a notícia publicada no dia 8 de novembro: "A secretaria de Segurança resolveu promover por ato de bravura e alto espírito cívico os policiais estaduais que participaram da diligência em que foi morto o terrorista Carlos Marighela."(JORNAL DO BRASIL, 1969, p.1). Este enunciado é um exemplo de que toda a ação policial e militar era considerada (ou pelo menos era assim que se fazia considerar) como um ato de coragem e de bravura.

Depois retoma o quadro de Paul Klee, para dar continuidade a seu comentário:

"Olho de nôvo a paisagem e de nôvo reconheço que covardia e liberdade estiveram em jôgo. A burguesia total cai ao se olhar Paysage aux Oiseaux Jaunes. Minha coragem, inteiramente possível, me amedronta. Começo até a pensar que entre os loucos há os que não são loucos. E que a possibilidade, a que é verdadeiramente, não é para ser explicada a um burguês quadrado. [...]"

O reencontro com o quadro é o ponto de contato dialógico para que o enunciador, neste momento, faça uma avaliação sobre o próprio Al-5, instituído em 13 de dezembro de 1968: "Olho de nôvo a paisagem e de nôvo reconheço que covardia e liberdade estiveram em jôgo.[...]", o uso do verbo no pretérito perfeito do indicativo: "estiveram" remete às ações passadas, mais exatamente, às decisões tomadas naquele momento, na verdade, uma reavaliação: "de nôvo reconheço que covardia e liberdade estiveram em jôgo". O uso da expressão "estiveram em jogo" permite demonstrar que o Al-5 representou o próprio ato de covardia que levou à 
perda da liberdade; aqueles que aprovaram o Ato só tinham interesse na ditadura ${ }^{78}$ e contaram o apoio da burguesia ${ }^{79}$, crítica que integra neste enunciado: " $A$ burguesia total cai ao se olhar Paysage aux Oiseaux Jaunes”. Para o enunciador, o encontro com o quadro é uma possibilidade de explicação para que outros cidadãos possam também interpretar a situação vivenciada: a de que a perda da liberdade resultou da covardia, e reconhece que a explicação não seria possível a um "burguês quadrado", criticando também àqueles mais conservadores. O diálogo com o quadro é uma das possibilidades que o enunciador sugere para a compreensão do acontecimento cotidiano; a outra, é por meio de palavras:

"E à medida que a pessoa quiser explicar se enreda em palavras, poderá perder a coragem, estará perdendo a liberdade. Les Oiseaux Jaunes não pede sequer que o entenda: êsse grau é ainda mais liberdade: não ter mêdo de ser compreendido. Olhando a extrema beleza dos pássaros amarelos calculo o que seria se eu perdesse totalmente o mêdo."

No entanto, a censura reprime a expressão verbal, o que pode ser verificado em: "poderá perder a coragem, estará perdendo a liberdade". É exatamente o que faz o enunciador, arrisca-se ao escrever este texto, apesar do medo que sente em fazê-lo.

\section{Esboço do sonho do líder}

\footnotetext{
${ }^{78}$ No dia em que foi votado o Ato Institucional n. ${ }^{5}$, de acordo com Gaspari (2002, p. 333), Costa e Silva abriu a sessão da reunião do Conselho Nacional de Segurança com um discurso em que ele se denominou o "legítimo representante da Revolução de março de 1964" e anunciou que sua decisão estava tomada e suspendeu a reunião por vinte minutos para que os ministros pudessem ler o texto. Retomada a reunião, passou a ouvir os ministros. Apenas o Chefe da Casa Civil, Rondon Pacheco, fez uma tentativa de abrandamento da ditadura. O vice-presidente Pedro Aleixo, na posição de jurista, denunciou que o Ato instituía a própria ditadura, mas, segundo o mesmo autor, em nenhum momento condenou a promulgação do Ato. Ventura (1988, p.279) comenta que os 22 eleitores colocaram-se a favor do Ato sem hesitações. "Uns, por inato desapego à dignidade, outros abrindo mão de suas histórias pessoais, e muitos, por não tê-las, renunciando à oportunidade de começar a construí-las [...] preferiam desempenhar o papel que o medo e a covardia lhes impunham."

${ }^{79}$ Desde a época do governo de João Goulart, o país era marcado pela radicalização política. De um lado os esquerdistas de outro os direitistas que se referiam aos setores das classes médias, grandes proprietários e políticos que carregavam a bandeira do anticomunismo, da fé religiosa e da moral (BARROS, 1999).
} 
Este texto integra o anterior, "Medo da libertação", e dialoga com a mesma realidade extraverbal, atualizando o acontecimento da ditadura sob o esboço do Presidente Costa e Silva. Assim começamos a leitura pelo enunciado-chave: "[...] $E$ antes que êles enfim se aproximassem definitivamente, ele gritou: sim, eu menti!" porque estabelece relação com os discursos contraditórios enunciados pelo Presidente, desde outubro de 1966, quando o Congresso o elegeu até a instauração do Al-5. O enunciador constrói o conto "Esbôço do sonho do líder" com o intuito de comentar que o presidente mentiu sobre a questão política do país. A alegoria é utilizada como recurso estilístico-composicional hermético para o leitor comum. Vejamos:

"O sono do líder é agitado. A mulher sacode-o até acordá-lo do pesadelo. Estremunhado êle se levanta, bebe um pouco de água, vai ao banheiro onde se vê diante do espelho. O que vê êle? Um homem de meia-idade. Êle alisa os cabelos das têmporas, volta a deitar-se. Adormece e a agitação do mesmo sonho recomeça. 'Não, não!', debate-se com a garganta sêca.

É que o líder se assusta enquanto dorme. O povo ameaça o líder? Não, pois se foi o povo que o elegeu, como líder do povo.[...]"

Deste trecho destacado, o enunciado - "O povo ameaça o líder? Não, pois se foi o povo que o elegeu, como líder do povo" - é organizado pelo enunciador em pergunta e resposta, construído a partir do diálogo que estabelece com outros enunciados que compõem o contexto extraverbal.

Por meio deste recurso de pergunta-resposta, o enunciador possivelmente faz crítica a uma autoridade máxima do país ${ }^{80}$, descrito como: "um homem de meiaidade", e a faz na alegoria do líder. O verbo ameaça integra o enunciado como posição axiológica do enunciador em relação ao tema do qual trata e se constrói na relação dialógica com outras avaliações, que circulavam nas mais diversas esferas da atividade humana ${ }^{81}$. Como exemplo, tem-se a notícia, já mencionada

\footnotetext{
${ }^{80}$ É possível que estivesse se referindo ao presidente Costa e Silva.

${ }^{81}$ De acordo com Bakhtin (2003, p.300), "todo o enunciado, além do seu objeto, sempre responde (no sentido amplo da palavra) de uma forma ou de outra aos enunciados do outro que o antecederam. [...] o próprio objeto do seu discurso [do falante] se torna inevitavelmente um palco de encontro com opiniões de interlocutores imediatos (na conversa ou na discussão sobre algum acontecimento do dia-a-dia) ou com pontos de vista, visões de mundo, correntes, teorias, etc.(no campo da comunicação cultural)."
} 
anteriormente, que foi publicada no $J B$, no dia 28 de dezembro de 1968, à página 1 , em que integra a declaração do presidente: "“[...] o Govêrno tentou o caminho da tolerância e recebeu em troca a intolerância. Experimentou a magnanimidade e passou por fraco. Procurou o apoio político e viu-se traído pelo impatriotismo de não poucos'”. A sensação de ameaça está incorporada no próprio discurso do presidente que também se constrói como resposta a outros enunciados porque, segundo Bakhtin (2003, p.300), "todo enunciado é um elo na cadeia da comunicação discursiva e não pode ser separado dos elos precedentes que o determinam tanto fora quanto dentro, gerando nele atitudes responsivas diretas e ressonâncias dialógicas".

O desdobramento do tema se dá por meio de seqüências de perguntas e respostas pelos quais ele expressa seus pontos de vista:

"O povo ameaça o líder? Não, pois escolheu-o no meio de lutas quase sangrentas. O povo ameaça o líder? Não, porque o líder cuida do povo. Cuida do povo?[...]"

Neste enunciado: "Cuida do povo?", a pergunta elaborada acentua um tom irônico que o interlocutor, seja ele o leitor do jornal, ou um participante direto do diálogo do cotidiano, percebe o sentido oposto deste. Isto porque, no cotidiano, circulavam muitos comentários sobre o presidente. Como um exemplo, destacamos o editorial do Jornal do Brasil (ver anexo N), datado em 22 de junho de 1968, intitulado "Omissão".

"A ausência constante diante de problemas urgentes que mais de perto falam á sensibilidade do País foi, aos poucos, contribuindo para distanciar o Govêrno dos seus governados. A Nação vive um dos momentos dramáticos, em que tudo se espera da autoridade. E a autoridade parece abdicar de sua função precípua, que é abrigar o povo sob o manto da lei." (JORNAL DO BRASIL, 1968, p.6)

Nesse enunciado, avalia-se a postura do presidente, mais exatamente, a falta de ação diante das manifestações dos estudantes e a violência que se espalhava pelas ruas da cidade naquele momento. Assim, podemos confirmar que a pergunta “Cuida do povo?" evidencia o sentido da omissão e não o cuidado. 
"Sim, o povo ameaça o líder do povo. O líder revolve-se na cama. De noite êle tem mêdo. Mesmo que seja um pesadelo sem história. De noite vê caras quietas, uma atrás da outra. E nenhuma expressão nas caras. É só este o pesadelo, apenas isso. Mas cada noite, mal adormece, mais caras quietas vão-se reunindo às outras, como na fotografia em branco e preto de uma multidão em silêncio.[...]“

O processo alegórico, com que o povo é descrito, possibilita compartilhar as impressões do enunciador relacionadas ao cidadão brasileiro, ao apagamento que a ditadura militar impôs com a censura. A palavra silêncio refere-se a toda a repressão vivenciada. O enunciado "Sim, o povo ameaça o líder do povo" se dá como resposta à pergunta: "O povo ameaça o líder?" e a resposta positiva sim é o ponto em que a crítica do enunciador torna-se mais significativa, pois expõe as dificuldades impostas aos cidadãos após ter sido decretado o Al-5. Sua conclusão avaliativa se dá pela forma como imprime os sentimentos dos cidadãos: "nenhuma expressão nas caras" e "caras quietas" e pelas cores que utiliza para expressar a tonalidade fria e ruim na referência ao branco e preto da fotografia e pelo uso de palavras com significado negativo: "terrível" e "monstruoso" que integram o enunciado a seguir:

"Parece uma terrível fotomontagem onde a inexpressão das caras dá-lhe mêdo. Nesse painel monstruoso, caras sem expressão. Mas o líder se cobre de suores porque os milhares de olhos vazios não pestanejavam."

Possivelmente, tudo isso para compor o "painel monstruoso" da censura que foi implementada e autorizada por um líder ditatorial. 


\section{Considerações Finais}

Os textos de Clarice Lispector escritos para o Jornal do Brasil também contribuíram para os estudos da história do jornalismo porque reportavam de modo diferenciado, um outro plano significativo das preocupações cotidianas vivenciadas, coletivamente, pelos cidadãos brasileiros diante dos acontecimentos da época.

No percurso de nossa pesquisa dialogamos com outros trabalhos que se dedicaram a estudar a obra e a vida de Clarice Lispector, incluindo em seus estudos sua produção para o jornal, mencionados no capítulo dois. Alguns estudiosos, do campo literário, consideraram-na como uma escritora intimista, preocupada também em retratar o feminino; outros, como uma cronista que escrevia para o jornal e que usara a coluna para exercitar sua obra ficcional. Essas classificações embora pertinentes são redutoras porque não contemplavam a multiplicidade de gêneros discursivos integrados na elaboração dos textos, nem na posição da enunciadora diante do ato de escrever que era a sua atividade humana mais específica.

No campo jornalístico, os jornalistas, que conviveram com Clarice e aqueles que estudaram o caderno B e os suplementos, viam-na como uma cronista literária, pois talvez não a imaginavam como cidadã consciente e participativa de seu tempo, capaz de desenvolver um olhar jornalístico.

As justificativas dadas para seu trabalho na imprensa sempre estiveram relacionadas à necessidade financeira, ao prestígio de escrever para um público diferenciado e porque era comum ter escritores colaborando para os jornais. Não desconsideramos esses aspectos, mas eles foram insuficientes para avaliarmos a relevância de seu trabalho para o jornal. Então estudamos o processo de construção de seus textos na relação com o Caderno B e com os acontecimentos do cotidiano.

Clarice escrevia para um caderno de cultura inovador e reconhecido por outros jornais brasileiros. O caderno B tratava os temas culturais com profundidade, sempre em tom de crítica e de debate. Era engajado aos acontecimentos da época sem deixar de estabelecer relação com a política e a economia do país. Diante de sua importância conquistada no meio jornalístico, passou a circular também nos finsde-semana. Tais informações nos foram confirmadas em entrevista realizada por 
mim com Alberto Dines ${ }^{82}$, que à época era editor-chefe do JB, que ela fora convidada a escrever a coluna porque o jornal necessitava de colaboradores de peso para garantir o mesmo sucesso aos sábados.

Consideramos, então, que sua colaboração foi relevante porque seus textos se constituíram como um processo de interação estabelecido na relação com outros textos da esfera jornalística e de outras esferas da atividade humana, com outros sujeitos sociais e com a realidade imediata da qual participavam, e dessa interação construiu seus pontos de vista críticos que integraram seus textos e, consequentemente, integraram o próprio jornal.

Também foi possível demonstrar que neles havia traços de seu olhar jornalístico quando reportava as sensações vividas pelos cidadãos brasileiros diante dos fatos do cotidiano, num período marcado pela censura que se instalou após o golpe militar de 1964 e pelo decreto do Ato Institucional n. ${ }^{\circ} 5$ em 1968, que instituiu um regime ditatorial de linha dura, levando a censura também às redações dos jornais. Seus textos reportavam os sentimentos de medo, de insegurança, de coragem, de covardia que se relacionavam com as questões de injustiça social, da perda de liberdade e outras questões ligadas à conjuntura político-econômica do país; acontecimentos exteriores com os quais Clarice Lispector cidadã conviveu e compartilhou com os outros cidadãos.

Conseguimos chegar a estes pontos porque apoiamos a leitura desses textos na concepção bakhtiniana de enunciado concreto que permitiu estudá-los sob o ponto de vista histórico, social e cultural. Para Bakhtin (2003), o enunciado concreto é a unidade da comunicação discursiva e sua natureza é dialógica, ocorre na relação imediata com a realidade (situação extraverbal) e na interação entre sujeitos sociais. Concebido como produção de linguagem, o texto se dá como expressão não apenas daquilo que é dado, ou seja, na relação com outros enunciados pertencentes a diferentes esferas da atividade humana, mas inclusive com o que é criado: como realização da idéia do próprio enunciador, isto é, como resposta compreensiva e valorativa em relação a outros enunciados, e na escolha que faz das formas de gênero discursivo.

Para estudarmos o texto como enunciado concreto, consideramos três elementos que Ihe são constitutivos: o conteúdo temático, o estilo e a construção

\footnotetext{
${ }^{82}$ Dines concedeu-nos entrevista em 8 de novembro de 2007.
} 
composicional, sempre na relação de interação com: o contexto extraverbal, compreendido como o horizonte espacial comum aos interlocutores; o conhecimento e a compreensão comum da situação por parte deles; a avaliação comum que os interlocutores fazem dessa situação.

A situação extraverbal foi um aspecto essencial para a realização do estudo proposto, assim extraímos da obra $O$ discurso na vida e o discurso na arte, como exemplo, o colóquio entre duas pessoas que se consistia numa única palavra: "Bem.", que Bakhtin apresenta para esclarecer significado do contexto extraverbal. Neste exemplo, ele se referia à concepção de que a palavra não comunica apenas pelo seu aspecto lingüístico de som abstrato, não significa apenas por um registro gráfico isolado, ou com um sentido semântico deslocado. Ela é uma materialidade sígnica que se concretiza e adquire sentido somente quando compartilhada com outrem que conhece o extraverbal referido. Por isso citamos o famoso colóquio que segue:

\begin{abstract}
Duas pessoas estão sentadas numa sala. Estão ambas em silêncio. Então, uma delas diz "Bem." A outra não responde.

[...]

No momento em que o colóquio acontecia, ambos os interlocutores olhavam para a janela e viam que começava a nevar: ambos sabiam que já era maio e que já era hora de chegar a primavera: finalmente, ambos estavam enjoados e cansados do prolongado inverno - ambos estavam esperando ansiosamente pela primavera e ambos estavam amargamente desapontados pela neve recente. É deste "conjuntamente visto" (flocos de neve do outro lado da janela, "conjuntamente sabido" (a época do ano maio) e "unanimemente avaliado" (cansaço do inverno, desejo da primavera) - é disso tudo que o enunciado depende diretamente, tudo isto Ihe dá sustentação [...] (BAKHTIN; VOLOSHINOV, s/d, p.4, grifos dos autores)
\end{abstract}

Partimos dessa visão de contexto para estudarmos todos os textos de Clarice Lispector escritos para o jornal entre 1967 e 1973. Levamos em conta as notícias que circularam no $J B$ e estudamos os acontecimentos desse período. Depois selecionamos quatro textos exemplares escritos nos anos de 1967, 1968 e 1969, em períodos distintos de censura militar, antes e após o Al-5 para fazermos a leitura e, assim, podermos compreender o processo de produção de sentidos de seus textos relacionados à situação extraverbal. 
Constatamos que Clarice Lispector na posição de enunciadora possuía um estilo-composicional particular para tratar dos temas escolhidos. A enunciadora, a partir de sua posição axiológica e na relação com o outro, recortava os eventos da vida cotidiana, como por exemplo, a censura às peças de teatro, sobre a falta de vagas para os estudantes universitários, a questão da fome, a censura instituída após o Al-5 e os reorganizava como um ato criativo seu que incluía um conjunto de procedimentos de construção dos textos, no estilo marcado pela pontuação diferenciada, pela elaboração de perguntas e respostas, pelo uso de metáforas e pela forma como interagia com os enunciados de outras esferas da atividade humana que estavam no jornal. Seus textos jornalísticos incorporaram e reacentuaram diferentes gêneros primários, tornando-os secundários e gerando outros sentidos, como exemplo, os diálogos da comunicação cotidiana, a carta, a prece e comentários que integraram esses textos com a finalidade de reiterar para o leitor um determinado ponto de vista em relação aos temas tratados, bem como reportar as sensações vivenciadas pelos cidadãos diante das dificuldades impostas pelas crises do país.

Estudar os textos de Clarice Lispector na esfera em que eles se produziram, a jornalística, possibilitou-nos uma outra leitura possível de seus textos, que demonstrou seu engajamento diante dos acontecimentos da época e toda a sua sensibilidade em relação às temáticas tratadas. 


\section{Fontes de pesquisa}

\section{Livros}

ABREU, Alzira Alves de (Org.). A imprensa em transição: o jornalismo brasileiro nos anos 50. Rio de janeiro: Fundação Getúlio Vargas, 1996.

ABREU, Alzira Alves de et al.(Coords.). Dicionário histórico-biográfico - pós 1930. 2. ed. rev. atual. Rio de Janeiro: FGV, 2001. v.II.

AGUIAR, Joaquim Alves de. Panorama da música popular brasileira: da bossa nova ao rock dos anos 80. In: SOSNOWSKI, Saúl; SCHWARTZ, Jorge. Brasil: o trânsito da memória. São Paulo: Edusp, 1994. p.141-174.

AGUILERA, Yanet (Org.). Preto no branco: a obra gráfica de Amílcar de Castro. São Paulo: Discurso Editorial; Belo Horizonte: UFMG, 2005.

ALMEIDA, Maria Hermínia Tavares de; WEIS, Luiz. Carro-zero e pau-de-arara: o cotidiano da oposição de classe média ao regime militar. In: SCHWARCZ, Lilia Moritz (Org.). História da vida privada no Brasil. São Paulo: Companhia das Letras, 2002. v. 4. p.319-409.

AMORIM, Marilia. O pesquisador e seu outro: Bakhtin nas ciências humanas. São Paulo: Musa, 2001.

ANDRADE, Jéferson de. Um jornal assassinado: a última batalha do Correio da Manhã. Rio de Janeiro: José Olympio, 1991.

ÂNGELO, Ivan. Nós, que amávamos tanto a literatura. In: SOSNOWSKI, S.; SCHWARTZ, J. (Orgs.). Brasil: o trânsito da memória. São Paulo: Edusp, 1994. p.69-73.

ARÁN, Pampa Olga; BAREI, Silvia. Texto, memória, cultura: el pensamiento de luri Lotman. 2. ed. rev. Córdoba: El Espejo Ediciones, 2006.

BAHIA, Juarez. Jornal, história e técnica. 4. ed. São Paulo: Ática, 1990. v.1 e 2. 
BAKHTIN, Mikhail; VOLOSHINOV, V. N. O discurso na vida e o discurso na arte. Tradução para uso didático feita por C. Tezza e C. A. Faraco.

BAKHTIN, Mikhail. Questões de literatura e de estética: a teoria do romance. 3. ed. São Paulo: Unesp, 1993.

. Problemas da poética de Dostoiévski. Tradução de Paulo Bezerra. 2.ed. Rio de Janeiro: Forense Universitária, 1997.

. Estética da criação verbal. Tradução do russo por Paulo Bezerra. 4.ed. São Paulo: Martins Fontes, 2003.

. O Freudismo: um esboço crítico. 1. ed. rev. São Paulo: perspectiva, 2004.

- A cultura popular na Idade Média e no Renascimento: o contexto de François Rabelais. 4. ed. São Paulo: Hucitec, 1999.

BARROS, Edgard Luiz de. O Brasil de 1945 a 1964. 6. ed. São Paulo: Contexto, 1999.

BRAIT, Beth. (Org.). Bakhtin: outros conceitos-chave. São Paulo: Contexto, 2006.

. Estilo. In: BRAIT, Beth (Org.). Bakhtin: outros conceitos-chave. São Paulo: Contexto, 2006. p.79-102.

. (Org.). Bakhtin: conceitos-chave. São Paulo: Contexto, 2005.

. Estilo, dialogismo e autoria: identidade e alteridade. In: Proceedings of the Eleventh International Bakhtin Conference. Curitiba: Universidade Federal do Paraná, 2004.

BRAIT, Beth; MELO, Rosineide. Enunciado/ enunciado concreto/enunciação. In: BRAIT, Beth. (Org.). Bakhtin: conceitos-chave. São Paulo: Contexto, 2005. p. 61-78.

BRANDÃO, Helena H. Nagamine. Subjetividade, argumentação, polifonia: a propaganda da Petrobrás. São Paulo: UNESP, 1998.

.Introdução à análise do discurso. 6.ed. Campinas: UNICAMP, 1997.

BROCA, Brito. Teatro das letras. Campinas: Unicamp, 1993. 
BUORO, Anamelia Bueno. Olhos que pintam: a leitura da imagem e o ensino da arte. São Paulo: Cortez, 2002.

CANDIDO, Antonio et al. A crônica: o gênero, sua fixação e suas transformações no Brasil. Campinas: Unicamp; Rio de Janeiro: Fundação Casa de Rui Barbosa, 1992.

CASTRO, Ruy. Chega de saudade: a história e as histórias da Bossa Nova. 3. ed. atual. São Paulo: Companhia das Letras, 2004.

CASTRO, Gustavo de; GALENO, Alex (Orgs.). Jornalismo e literatura: a sedução da palavra. São Paulo: Escrituras, 2002. Coleção Ensaios Transversais.

CHAPARRO, Carlos Manuel. Pragmática do jornalismo: buscas práticas para uma teoria da ação jornalística. São Paulo: Summus, 1994.

. Sotaques d'aquém e d'além mar: percursos e gêneros do jornalismo português e brasileiro. Santarém: Jortejo, 2000.

CHIAPPINI, Ligia. Clarice e a crítica: por uma perspectiva integradora. In: PONTIERI, Regina (Org.).Leitores e leituras de Clarice Lispector. São Paulo: Hedra, 2004.

CLARICE LISPECTOR. Cadernos de literatura brasileira: Instituto Moreira Salles, São Paulo, n.17-18, 2004. Edição especial.

COELHO, Marcelo. Notícias sobre a crônica. In: CASTRO, Gustavo de; GALENO, Alex (Orgs.). Jornalismo e literatura: a seduação da palavra. São Paulo: Escrituras, 2002. (Coleção Ensaios Transversais). p.155-162.

COHN, Gabriel. Problemas da industrialização no século XX. In: MOTA, Carlos Guilherme (Org.). Brasil em perspectiva. 20.ed. Rio de Janeiro: Bertrand Brasil, 1995. p. $283-316$.

COSTA, Cristiane. Pena de aluguel: escritores jornalistas no Brasil 1904-2004. São Paulo: Companhia da Letras, 2005.

DINES, Alberto. O papel do jornal: uma releitura. 6.ed. atual. São Paulo: Summus, 1986. 
FABBRINI, Ricardo. Pulsões do construtivismo. In: AGUILERA, Yanet (Org.). Preto no branco: a obra gráfica de Amílcar de Castro. São Paulo: Discurso Editorial; Belo Horizonte: UFMG, 2005. p.10-29.

FARACO, C. A.; TEZZA, C.; CASTRO, G. de (Org.). Diálogos com Bakhtin. 3. ed. Curitiba: UFPR, 2001.

FARACO, Carlos Alberto; TEZZA, Cristóvão; CASTRO, Gilberto de. (Orgs.) Vinte ensaios sobre Mikhail Bakhtin. Petrópolis: Vozes, 2006.

FARACO, Carlos Alberto. Linguagem e diálogo: as idéias lingüísticas do círculo de Bakhtin. Curitiba: Criar Edições, 2003.

FARO, J. S. Revista Realidade, 1966-1968: tempo da reportagem na imprensa brasileira. Canoas: ULBRA; Porto Alegre: AGE, 1999.

FARIA, João Roberto. Alencar: a semana em revista. In: CANDIDO, Antonio et al. A crônica: o gênero, sua fixação e suas transformações no Brasil. Campinas: UNICAMP; Rio de Janeiro: Casa de Rui Barbosa, 1992. p.301-316.

FAUSTO, Boris. A experiência democrática (1945-1964). In: História Concisa do Brasil. São Paulo: Edusp, 2001. p. 119 - 256.

FERREIRA, Teresa Cristina Montero. Eu sou uma pergunta: uma biografia de Clarice Lispector. Rio de Janeiro: Rocco, 1999.

GALVÃO, Walnice Nogueira. As falas, os silêncios (literatura e imediações: 19641988). In: SOSNOWSKI, Saúl; SCHWARTZ, Jorge. (Orgs.). Brasil: o trânsito da memória. São Paulo: Edusp, 1994. p.185-195.

GASPARI, Elio. A ditadura envergonhada. São Paulo: Companhia das Letras, 2002.

GOMES, Ângela de Castro. A política brasileira em busca da modernidade: na fronteira entre o público e o privado. In: SCHWARCZ, Lilia Moritz (Org.). História da vida privada no Brasil. São Paulo: Companhia das Letras, 2002. v. 4. p.489-558.

GORENDER, Jacob. Combate nas trevas. 5. ed. rev. amp. atual. São Paulo: Ática, 1998. 
GOTLIB, Nádia Battella. Clarice: uma vida que se conta. São Paulo: Ática, 1995.

GULLAR, Ferreira. Entrevista. In: AGUILERA, Yanet (Org.). Preto no branco: a obra gráfica de Amílcar de Castro. São Paulo: Discurso Editorial; Belo Horizonte: UFMG, 2005. p.46-59.

HALL, Stuart. A identidade cultural na pós-modernidade. Tradução de Tomaz Tadeu da Silva e Guacira Lopes Louro. 7. ed. Rio de Janeiro: DP\&A, 2002.

HOLQUIST, Michael. Dialogism: Bakhtin and his world. 2nd ed. New York: Routledge, 2002.

HOHFELDT, Antonio; BARBOSA, Marialva. (Org.). Jornalismo no século XXI: a cidadania. Porto Alegre: Mercado Aberto, 2002.

JARDIM, Reynaldo. Entrevista. In: AGUILERA, Yanet (Org.). Preto no branco: a obra gráfica de Amílcar de Castro. São Paulo: Discurso Editorial; Belo Horizonte: UFMG, 2005. p. 60-69.

LAGE, Nilson. Linguagem jornalística. 5. ed. São Paulo: Ática, 1997.

LESSA, Washington Dias. Amílcar de Castro e a reforma do "jornal do brasil". In: AGUILERA, Yanet (Org.). Preto no branco: a obra gráfica de Amílcar de Castro. São Paulo: Discurso Editorial; Belo Horizonte: UFMG, 2005. p.70-87.

LIMA, Alceu Amoroso. O jornalismo como gênero literário. São Paulo: Com-Arte; São Paulo: EDUSP, 1990.

LIMA, Patrícia Ferreira de Souza. Caderno B do Jornal do Brasil: trajetória do segundo caderno na imprensa brasileira (1960-85). Tese (Doutorado em História Social) - Instituto de Filosofia e Ciências Sociais da Universidade Federal do Rio de Janeiro- UFRJ, Rio de Janeiro, 2006.

LISPECTOR, Clarice. Entrevistas. Rio de Janeiro: Rocco, 2007. . Felicidade Clandestina. Rio de Janeiro: Rocco, 1998. . Uma aprendizagem ou o livro dos prazeres. Rio de Janeiro: Rocco, 1998 
. A descoberta do mundo. Rio de Janeiro: Rocco, 1999a.

. De corpo inteiro. Rio de Janeiro: Rocco, 1999b.

. Chico Buarque ou Xico Buark. In: LISPECTOR, Clarice. De corpo inteiro. Rio de Janeiro: Rocco, 1999b. p.64-69.

. Onde estivestes de noite. Rio de Janeiro: Rocco, 1999c.

LORENZOTTI, Elizabeth de Souza. Do artístico ao jornalístico: vida e morte de um Suplemento Literário de O Estado de S. Paulo (1956 a 1974). 2002. Dissertação (Mestrado) - Escola de Comunicação e Artes da Universidade de São Paulo, São Paulo, 2002.

LOTMAN, luri M. La semiosfera: semiótica de la cultura y Del texto. Selección y traducción del ruso por Desiderio Navarro. Madrid: Cátedra, 1996. vol. I, II e III.

LUCAS, Fábio. A crise da cultura literária no Brasil pós-64. In: SOSNOWSKI, S.; SCHWARTZ, J. (Orgs.). Brasil: o trânsito da memória. São Paulo: Edusp, 1994. p.131-139.

MACHADO, Irene A. O romance e a voz: a prosaica dialógica de M. Bakhtin. Rio de Janeiro: Imago, São Paulo: FAPESP, 1995.

. Gêneros discursivos. In: BRAIT, Beth (Org.). Bakhtin: conceitos-chave. São Paulo: Contexto, 2005. p. 151-166.

MANZO, Lícia. Era uma vez Eu: a não ficção na obra de Clarice Lispector. Curitiba: Secretaria de Estado da Cultura; Curitiba: The Document Company -Xerox do Brasil, 1997.

MEDEL, Manuel Angel Vázquez. Discurso literário e discurso jornalístico: convergências e divergências. In: CASTRO, Gustavo de; GALENO, Alex (Org.). Jornalismo e literatura: a sedução da palavra. São Paulo: Escrituras, 2002. Coleção Ensaios Transversais. p.15-25.

MEDITSCH, Eduardo. O conhecimento do jornalismo. Florianópolis: UFSC, 1992. 
MELO, José Marques de. A crônica. In: CASTRO, Gustavo de; GALENO, Alex (Orgs.). Jornalismo e literatura: a sedução da palavra. São Paulo: Escrituras, 2002. (Coleção Ensaios Transversais). p. 139-154.

. A opinião no jornalismo brasileiro. 2. ed. rev. Petrópolis: Vozes, 1994.

MELLO, João Manuel Cardoso de; NOVAIS, Fernando A. Capitalismo tardio e sociabilidade moderna. In: SCHWARCZ, Lilia Moritz (Org.). História da vida privada no Brasil. São Paulo: Companhia das Letras, 2002. v. 4. p. 559-658.

MEYER, Marlyse. Voláteis e versáteis. De variedades e folhetins se fez a chronica. In: CANDIDO, Antonio et al. A crônica: o gênero, sua fixação e suas transformações no Brasil. Campinas: UNICAMP; Rio de Janeiro: Casa de Rui Barbosa, 1992. p.93133.

MICELI, Sergio. Intelectuais à brasileira. São Paulo: Companhia das Letras, 2001.

MICHALSKI, Yan. A crise do teatro dentro da crise maior. In: SOSNOWSKI, S.; SCHWARTZ, J.(Orgs.). Brasil: o trânsito da memória. São Paulo: Edusp, 1994. p.113-120.

MONTES, Maria Lucia. As figuras do sagrado: entre o público e o privado. In: SCHWARCZ, Lilia Moritz (Org.). História da vida privada no Brasil. São Paulo: Companhia das Letras, 2002. v. 4. p. 64-171.

MORSON, Gary Saul; EMERSON, Caryl. Mikhail Bakhtin: creation of a prosaics. Standford University Press: Standford, 1999.

NEVES, Margarida de Souza. Uma escrita do tempo: memória, ordem e progresso na crônicas cariocas. In: CANDIDO, Antonio et al. A crônica: o gênero, sua fixação e suas transformações no Brasil. Campinas: Unicamp; Rio de Janeiro: Fundação Casa de Rui Barbosa, 1992.

NUNES, Aparecida Maria. Clarice Lispector "jornalista". Dissertação (Mestrado em Literatura Brasileira). Faculdade de Filosofia, Letras e Ciências Humanas da Universidade de São Paulo- USP, São Paulo, 1991 
- Páginas femininas de Clarice Lispector. 1997. Tese (Doutorado em Literatura Brasileira) - Faculdade de Filosofia, Letras e Ciências Humanas da Universidade de São Paulo- USP, São Paulo, 1997.

PEREIRA, Wellington. Crônica: arte do útil ou do fútil? João Pessoa: Idéia, 1994.

PIZA, Daniel. Jornalismo Cultural. São Paulo: Contexto, 2003.

RIBEIRO, Ana Paula Goulart. Imprensa e história no Rio de Janeiro dos anos 50. 2000. Tese (Doutorado em Comunicação) - Universidade Federal do Rio de Janeiro -UFRJ, Rio de Janeiro, 2000.

ROSENBAUM, Yudith. Metamorfoses do mal: uma leitura de Clarice Lispector. São Paulo: Edusp, 1999.

. No território das pulsões. In: CLARICE LISPECTOR. Cadernos de literatura brasileira: Instituto Moreira Salles, São Paulo, n.17-18, 2004. Edição especial. p. 261-279.

ROSSI, Clóvis. O que é jornalismo. São Paulo: Brasiliense, 1998.

SANT'ANNA, Sabrina Marques Parracho. "Pecados de Heresia": trajetória do concretismo carioca. Dissertação (Mestrado em Sociologia e Antropologia) Universidade do Rio de Janeiro - UFRJ, Rio de Janeiro, 2004.

SANFELICE, José Luís. Movimento estudantil: a UNE na resistência ao golpe de 64 . São Paulo: Cortez, 1986.

SCOPEL, Mariza Helena. Modernidade e vanguarda: o Suplemento Dominical do Jornal do Brasil e o manifesto neoconcreto (1956-1961). 2002. Dissertação (Mestrado em Comunicação e Cultura) - Universidade Federal do Rio de Janeiro UFRJ, Rio de Janeiro, 2002.

SILVA, Wilsa Carla Freire da. Cultura em pauta: um estudo sobre o jornalismo cultural. 1997. Dissertação (Mestrado em Ciências da Comunicação) - Escola de Comunicação e Artes da Universidade de São Paulo, São Paulo, 1997. 
SOBRAL, Adail. Ato/atividade e evento. In: BRAIT, Beth. Bakhtin: conceitos-chave. São Paulo: Contexto, 2005. p.11 -36.

SODRÉ, Muniz; PAIVA, Raquel. O império do grotesco. Rio de Janeiro: Mauad, 2002.

SODRÉ, Nélson Werneck. História da imprensa no Brasil. 4. ed. Rio de Janeiro: Mauad, 1999.

SOSNOWSKI, S.; SCHWARTZ, J. (Orgs.). Brasil: o trânsito da memória. São Paulo: Edusp, 1994.

TAGÉ, Terezinha. Cultura e vida cotidiana no jornal. São Paulo: Com-Arte, 2006. . Minudências. In: - Cultura e vida cotidiana no jornal. São Paulo: Com-Arte, 2006. p. 84-85.

. Os mistérios de Clarice Lispector. In: . Cultura e vida cotidiana no jornal. São Paulo: Com-Arte, 2006. p. 155-157.

TOLEDO, Caio Navarro de. O governo Goulart e o golpe de 64. São Paulo: Brasiliense, 1997.

TRAQUINA, Nelson. Teorias do jornalismo: porque as notícias são como notícias. 2. ed. Florianópolis: Insular, 2005a. v.I

. Teorias do jornalismo: a tribo jornalística - uma comunidade interpretativa transnacional. Florianópolis: Insular, 2005b. v.II

VENTURA, Zuenir. 1968: o ano que não terminou. Rio de Janeiro: Nova Fronteira, 1988.

WAINER, Samuel. Minha razão de viver: memórias de um repórter. 18.ed. Rio de Janeiro: Record, 2001.

WEINHARDT, Marilene. O suplemento literário d'O Estado de São Paulo 1956-67: subsídios para a história da crítica literária no Brasil. 1982. Dissertação (Mestrado) Faculdade de Filosofia, Letras e Ciências Humanas da Universidade de São Paulo, São Paulo, 1982. v.1. 
2. Jornais

CARPINEJAR, Fabrício. Os pássaros aprenderam a nadar. O Estado de S. Paulo, São Paulo, 7 out. 2007. Caderno Cultura, Caderno D, p.12.

GOTLIB, Nádia Battella. Crônicas de Clarice observam com ironia o universo feminino. Folha de S. Paulo, São Paulo, 7 out. 2006. Ilustrada, Caderno E, p. 7.

GULLAR, Ferreira. Presença de Clarice. Folha de S. Paulo, São Paulo, 20 mai. 2007. Ilustrada, Caderno E, p.12.

JORNAL DO BRASIL. Rio de Janeiro, 15 set. 1960. Caderno B. 8 p.

. Rio de Janeiro, 5 mar. 1967. Edição Completa.

. Rio de Janeiro, 7 mar. 1967. Edição Completa.

. Rio de Janeiro, 26 ago. 1967. Edição Completa.

. Rio de Janeiro, 16 set. 1967. Edição Completa.

. Rio de Janeiro, 17/18 set. 1967. Edição Completa.

. Rio de Janeiro, 26 set. 1967. Edição Completa.

. Rio de Janeiro, 7 out. 1967. Edição Completa.

Rio de Janeiro, 17 fev. 1968. Edição Completa.

. Rio de Janeiro, 30 mar. 1968. Edição Completa.

. Do protesto à desordem. Rio de Janeiro, 31 mar./1 abr.1968. $1^{\circ}$ Caderno, p.6.

Rio de Janeiro, 22 jun. 1968. Edição Completa.

. Rio de Janeiro, 14 dez. 1968. Edição Completa.

. Rio de Janeiro, 20 dez. 1968. Edição Completa.

. Rio de Janeiro, 28 dez. 1968. Edição Completa.

. Rio de Janeiro, 31 mai. 1969. Edição Completa.

. Rio de Janeiro, 8 nov. 1969. Edição Completa.

. Rio de Janeiro, 15 nov. 1969. Edição Completa. 
. Rio de Janeiro, 22 nov. 1969. Edição Completa.

. Rio de Janeiro, 21 mar. 1970. Edição Completa.

. Rio de Janeiro, 18 abr. 1970. Edição Completa.

. Rio de Janeiro, 25 abr. 1970. Edição Completa.

. Rio de Janeiro, 20 fev. 1971. Edição Completa.

. Rio de Janeiro, 27 mar. 1971. Edição Completa.

. Rio de Janeiro, 23 out. 1971. Edição Completa.

. Rio de Janeiro, 20 out. 1971. Edição Completa.

. Rio de Janeiro, 24 jun. 1972. Edição Completa.

. Rio de Janeiro, 9 set. 1972. Edição Completa.

. Rio de Janeiro, 6 jan. 1973. Edição Completa.

. Rio de Janeiro, 9 jun. 1973. Edição Completa.

. Rio de Janeiro, 10 nov. 1973. Edição Completa.

. Rio de Janeiro, 15 set. 1990. Caderno B.

LISPECTOR, Clarice. Vitória nossa / Tanto esforço / O processo. Jornal do Brasil, Rio de Janeiro, 26 ago. 1967. Caderno B, p.2.

. Prece por um padre / não sentir / ir para / daqui a vinte e cinco anos. Jornal do Brasil, Rio de Janeiro, 16 set. 1967. Caderno B, p.2.

- Medo do desconhecido / Dos palavrões no teatro / Chacrinha?! Jornal do Brasil, Rio de Janeiro, 7 out. 1967. Caderno B, p.2.

. Uma coisa / Lição de piano / Bolinhas. Jornal do Brasil, Rio de Janeiro, 9 dez. 1967. Caderno B, p. 2.

- Carta ao ministro da Educação. Jornal do Brasil, Rio de Janeiro, 17 fev. 1968. Caderno B, p.2.

Adeus, vou-me embora! Jornal do Brasil, Rio de Janeiro, 20 abr. 1968.

Caderno B, p. 2. 
. Estado de graça - trecho. Jornal do Brasil, Rio de Janeiro, 6 abr. 1968. Caderno B, p. 2.

. Faz de conta / "Precisa-se" ISão Paulo. Jornal do Brasil, Rio de Janeiro, 19 out. 1968. Caderno B, p. 2.

- Lembrança de filho pequeno / A fome / Mistérios de um sono / Seguir a força maior / Só como processo / As dores da sobrevivência: Sérgio Porto. Jornal do Brasil, Rio de Janeiro, 28 set. 1968. Caderno B, p. 2.

Aprendendo a viver. Jornal do Brasil, Rio de Janeiro, 28 dez. 1968. Caderno B, p.2.

. Medo da libertação. Jornal do Brasil, Rio de Janeiro, 31 mai. 1969. Caderno B, p.2.

. Cem anos de solidão. Jornal do Brasil, Rio de Janeiro, 15 nov. 1969. Caderno B, p.2.

. A máquina está crescendo / Eu tomo conta do mundo. Jornal do Brasil, Rio de Janeiro, 21 mar. 1970. Caderno B, p.2.

. Inauguração solene do futuro. Jornal do Brasil, Rio de Janeiro, 18 abr. 1970. Caderno B, p.2.

. Tradução atrasada. Jornal do Brasil, Rio de Janeiro, 25 abr. 1970. Caderno B, p.2.

. A pesca milagrosa / Lembrar-se / Crônica social / A Academia Brasileira de Letras. Jornal do Brasil, Rio de Janeiro, 20 fev. 1971. Caderno B, p.2.

. "Criar um quadro é criar um mundo novo". Jornal do Brasil, Rio de Janeiro, 27 mar. 1971. Caderno B, p.2.

. Cérebro eletrônico. Jornal do Brasil, Rio de Janeiro, 23 out. 1971. Caderno B, p.2.

. Prêmio Nobel de literatura no Rio. Jornal do Brasil, Rio de Janeiro, 30 out. 1971. Caderno B, p.2.

. Autocrítica / Solidão e falsa solidão. Jornal do Brasil, Rio de Janeiro, 24 jun. 1972. Caderno B, p.2. 
. Vários. Jornal do Brasil, Rio de Janeiro, 9 set. 1972. Caderno B, p.2.

. Uma tarde plena. Jornal do Brasil, Rio de Janeiro, 6 jan. 1973. Caderno B, p.2.

. O arranjo. Jornal do Brasil, Rio de Janeiro, 9 jun. 1973. Caderno B, p.2.

. Mulher demais. Jornal do Brasil, Rio de Janeiro, 10 nov. 1973. Caderno B, p.2.

. Por causa de um bule de bico rachado / Apenas um cisco no olho. Jornal do Brasil, Rio de Janeiro, 29 nov. 1973. Caderno B, p.2.

MICHALSKI, Yan. O teatro imoral, ou os corcundas por persuasão. Jornal do Brasil, Rio de Janeiro, 30 mar. 1973. Caderno B, p.4.

RITO, Lucia. A mais completa tradução do Rio chega aos 30 anos. Jornal do Brasil, Rio de Janeiro, 15 set. 1990. Caderno B, p. 8.

ROCHA, Marília Librandi. Todas as odisséias de Clarice Lispector. Jornal da Tarde, São Paulo, 9 out. 1999. Caderno de Sábado, p.6.

ROLLEMBERG, Marcelo. A bruxa das palavras. Jornal da USP, Cidade Universitária, 4 out. 1999. p.14

3. Revistas

LISPECTOR, Clarice. Negrão de Lima. Revista Manchete. Rio de Janeiro: Bloch Editores, 22 mar. 1968. Seção Diálogos Possíveis com Clarice Lispector, p.96-98. . Yolanda Costa e Silva. Revista Manchete. Rio de Janeiro: Bloch Editores, 5 abr. 1969. Seção Diálogos Possíveis com Clarice Lispector, p.104-105.

. Mário Andreazza. Revista Manchete. Rio de Janeiro: Bloch Editores, 10 mai. 1969. Seção Diálogos Possíveis com Clarice Lispector, p.96-98. 
LERNER, Júlio. A última entrevista de Clarice Lispector. Shalom. São Paulo, ano 27, n.296, p.62-69, 1992.

RONCARI, Luiz. A estampa da rotativa na crônica literária. Boletim Bilbiográfico: Biblioteca Mário de Andrade, São Paulo, v.46, n.1/4, p. 9-16, jan./dez. 1985.

4. Internet (e-textos)

COELHO, Marcelo. Clarice "repórter" inibe entrevistados. Folha de S. Paulo, São Paulo, 5 mai. 2007. Disponível em: <http://www.folhaonline.com.br>. Acesso em: 7 jun. 2007.

COSTA, Maria Aparecida; DEVALLE, Antony. Memória da imprensa carioca/UERJ: entrevista com Alberto Dines. 2002. Disponível em: <http://www.observatorioda Imprensa.com.br>. Acesso em: 25 out. 2007.

GARCIA, Miliandre. A questão da cultura popular: as políticas culturais do Centro Popular de Cultura (CPC) da União Nacional dos Estudantes (UNE). Revista Brasileira de História, São Paulo, v.24, n.47, jul., p.127-162, 2004. Disponível em <http://www.scielo.br/pdf/rbh/v24n47/a06v2447.pdf>. Acesso em: 7 ago. 2007.

GULLAR, Ferreira. Perfil: Reynaldo Jardim. Observatório da Imprensa. Seção Entre Aspas. 10 dez. 2006. Disponível em: <http://observatorio.ultimosegundo.ig.com.br/ Asp?cod=411ASP002>. Acesso em: 9 jun.2007.

LAGÔA, Maria Beatriz da Rocha. O avesso do visível: poética de Paul Klee. Rio de Janeiro, Revista Alea, v.8, n.1, p. jan/jun. 2006. Disponível em: <http://www.scielo.br>. Acesso em: 12 dez.2007.

NAPOLITANO, Marcos. A MPB sob suspeita: a censura musical vista pela ótica dos serviços de vigilância política (1968-1981). Revista Brasileira de História. São Paulo, v.24, n.47, p.103-126, 204. Disponível em:<http://www.scielo.br>. Acesso em: 15 mai. 2007. 
NAVA, Rosa. Censura mudou jornalismo brasileiro. Trabalho apresentado no $4^{\circ}$ Encontro Nacional da Rede Alfredo de Carvalho, São Luís, mai./jun. 2006. Disponível em: <http://www.jornalismo.ufsc.br/redealcar/cd4/midiologia/RosaNava. doc>. Acesso em: 3 nov.2007.

NAVES, Santuza Cambria. Da Bossa Nova à Tropicália: contenção e excesso na música popular. Revista Brasileira de Ciências Sociais: Associação Nacional de PósGraduação e Pesquisa em Ciências Sociais, v. 15, n. 43, p. 35-44, jun. 2000. Disponível em: <http://www.scielo.br>. Acesso em: 22 abr. 2007.

PATRIOTA, Rosângela. A cena tropicalista no Teatro Oficina de São Paulo, São Paulo. Revista História, Franca, v. 22, n. 1, p. 135-163, 2003. Disponível em: <http://www.Scielo.br//scielo.php?script=sci_arttext\&pid=S010190742003000100006 \&lng=en\&nrm=iso>. Acesso em: 30 jul. 2007.

TONETTO, Maria Cristina. Cultura e imagem: o cinema neo-realista no mercosul 1955-1962. 2006. Dissertação (Mestrado em Integração Latino-Americana) Universidade Federal de Santa Maria. Centro de Ciências Sociais e Humanas, Rio Grande do Sul, 2006. Disponível em: <http://cascavel.cpd.ufsm.br/tede/tde_arquivos/ 27/TDE-2006-12-0606T153922Z-269/Publico/mariacristina.pdf>. Acesso em: 2 jul.2007.

5. Vídeo

CLARICE LISPECTOR. Gravação em vídeo. Produção de Ricardo Soares. Direção de Rogério Brandão. São Paulo: Fundação Padre Anchieta, 1977. 1 videocassete (77min), VHS, son., color. Documentário contendo entrevista da escritora concedida à TV Cultura com participação especial de Gastão Moreira. 
Anexos 
Anexo A - Outros textos de Clarice Lispector escritos para o Caderno B

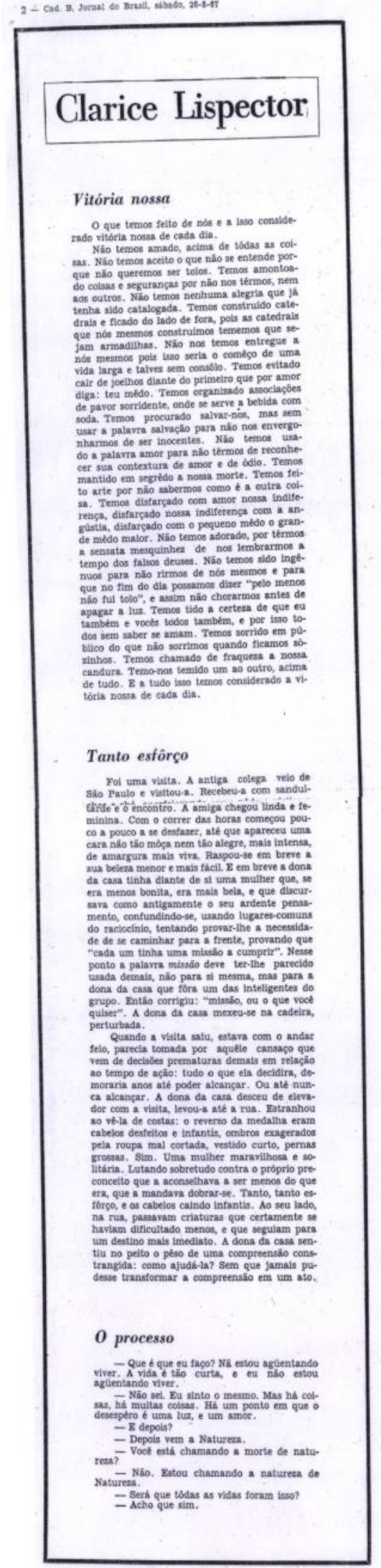

BARBARA HELIODORA

Como vencer

$$
\text { no palco }
$$

fazendo fôrça

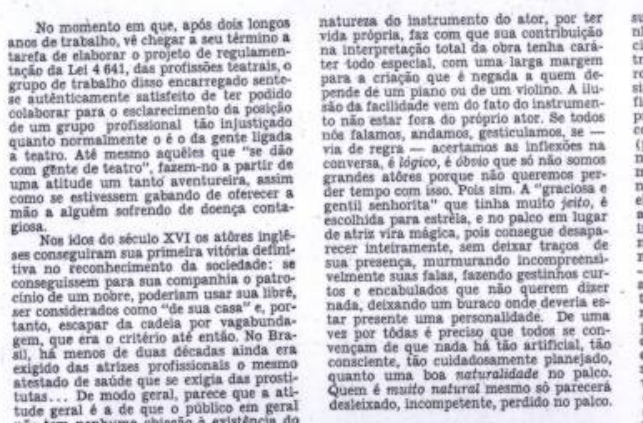

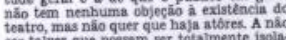

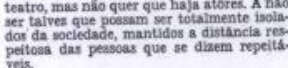
O ator como marginal

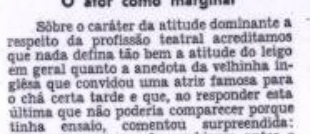

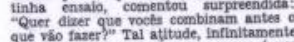

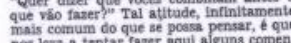

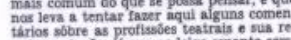

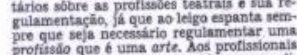

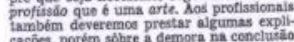

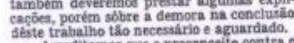

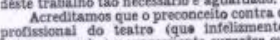

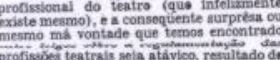

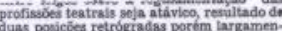

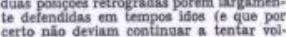

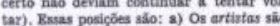

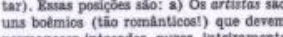

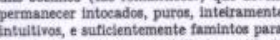

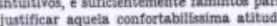
de "en sour melhor do que Ele", de indull

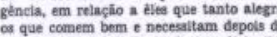

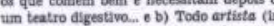

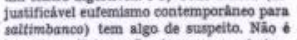

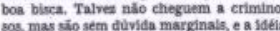

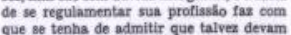
quet levados a s seros, encrandos como mem-

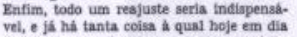
temos g guen nos ajustar, que realimente to

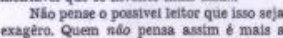

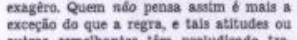
a tem prejuacicado treno Brasili. 86 agora, em nossos dias, 6 que

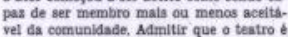

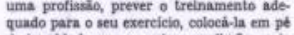

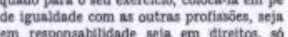
em responsabibitade seja em ditrettos, so

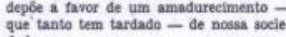
acué

A necessidade do aprendizado Se hé quem nibo chegue aos extrento do em reiacioio as teatro, a quases totalida. de das pessons acroditus serriamente que pari 6 universal e generososmente cutorgado pela naturean. Essas mesmas pessoas reconhe-
cem a necessidade de preparo thenico em interpretes de outras arter; concordam, por exemplo, em que seri - na meihor das ht.

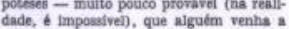
ser um grande pianista sem passar por

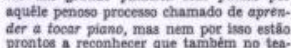
tro seja preciso aprender a tocar alguma coisa. E no entanto o processoo do treina-
mento do ator corresponde prectsamente a

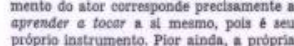

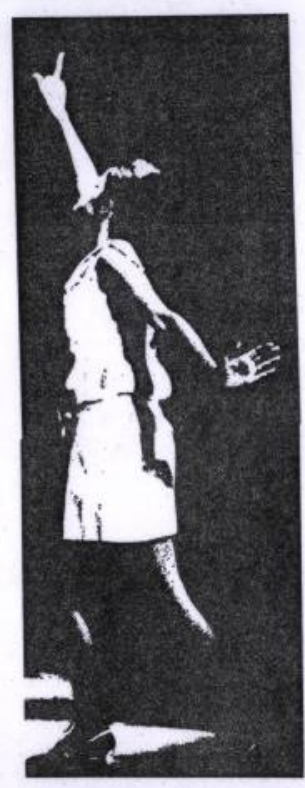

A grande complexidade Ga vida teatral que ge reúnem para a tormaçio de ume $e$ petaculo to que parece escapar ao pobi. a do veatro tax por isso; a llusaio de tacll.

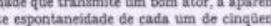
th, cem ou duszentos espetieculos de uma

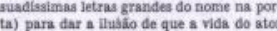
tuma grande e ininterrupta apoteose de $^{\circ}$

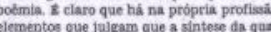
idated profisiononal reside em se trequientar barrinho que esth $\mathrm{em}$ evidencia no mo. mento, mas nío cretio que qualquer outta protiasia poses diser que os

R. 6 Justamente por sua complexidade istican ede. ental da integraçio do trabalibo de todicas deve, de profiasionais altamente treinados capaze de se intograr com tsse estranhio que caracteriza todo o trabaliho no te.

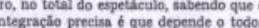
que o trabuilino de canda un á pode ser con. rio na mediata em que ile souber criar pro. Jeito näo, talento sim

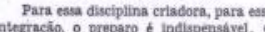

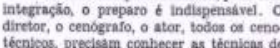
clasamente dentro dor limitee de sua funço

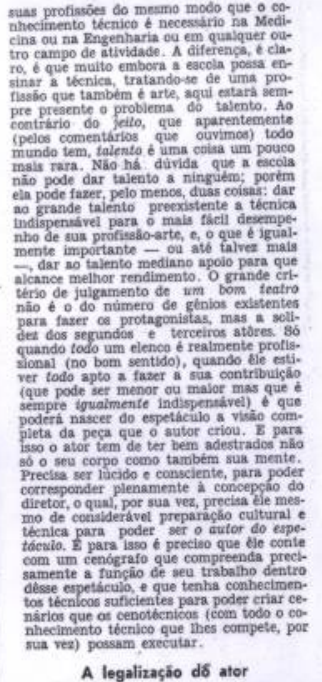

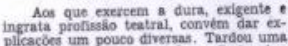

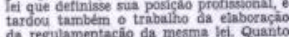

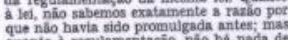

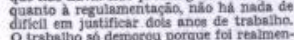

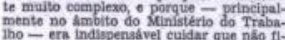

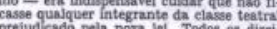

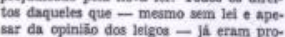

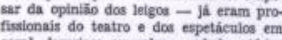

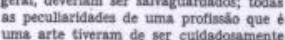

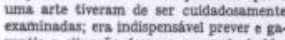
tria cinematograficate, e nio permititir que

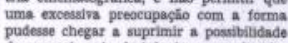
OG Grupo de Tratalitho conclulus sua ta.

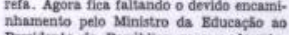
Presidente din Repobibica para a a dererta.

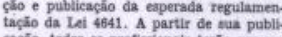

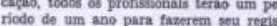
tro. Conalisses para a contagem de tempe.

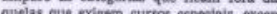

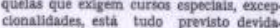
Beria ingtano supor que basta i clas.

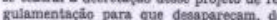
diap para a noite, todos os seus inumeros cocro que taca com que o insano trabaliha do um espetieculo e sua preparacia sejam de

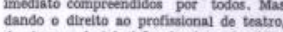

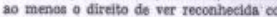

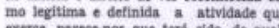

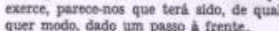
8 lamentivel que tenha de ver consto

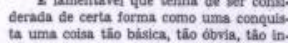
tanto tering

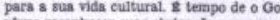

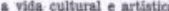
seja atse o cometeo de una nova era, do filis

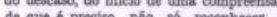
condiçio protissional de quem trabaila en

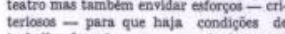

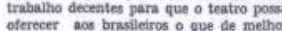
seus talentos - adestradoce protissionsid.

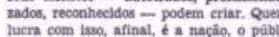

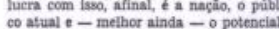




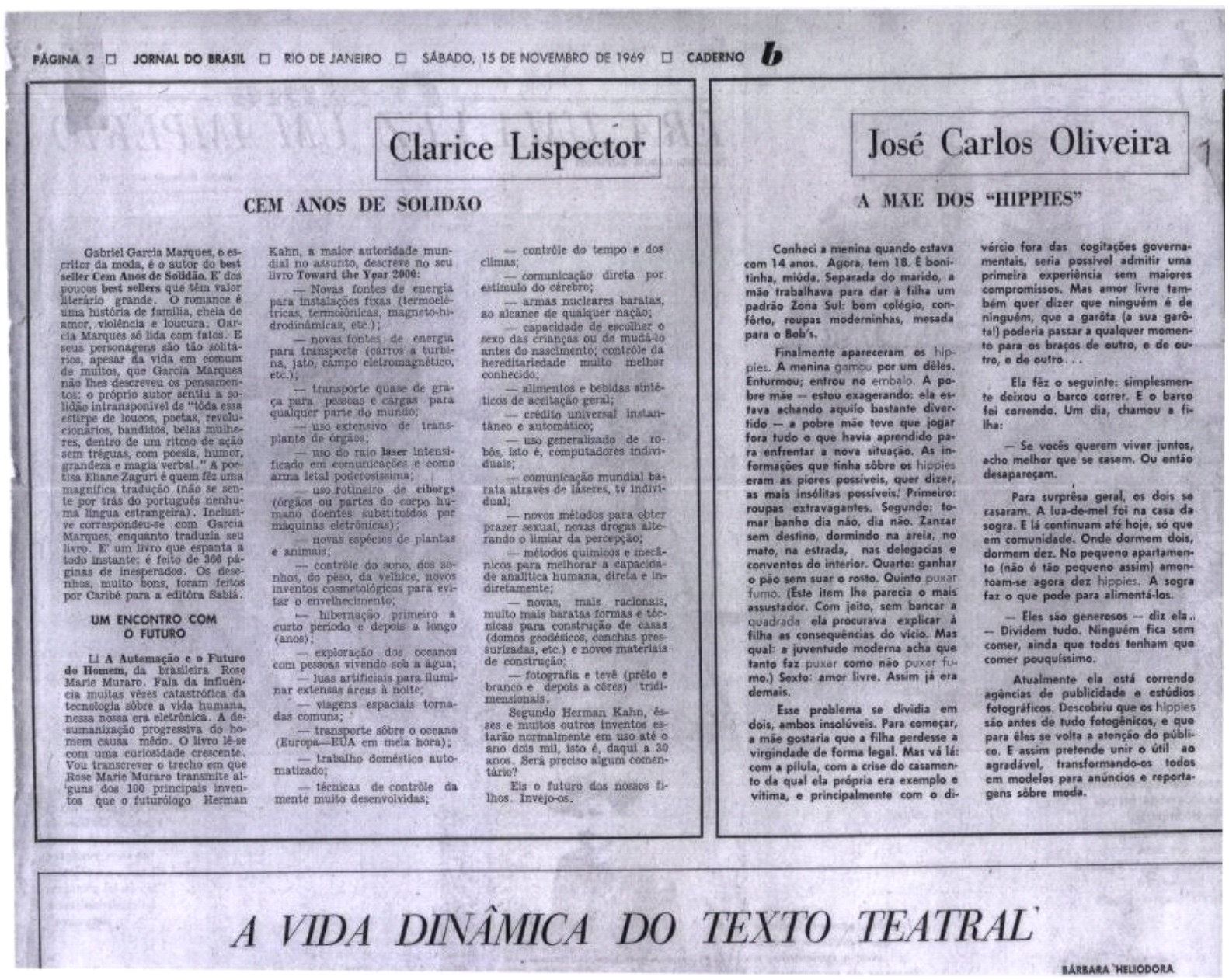




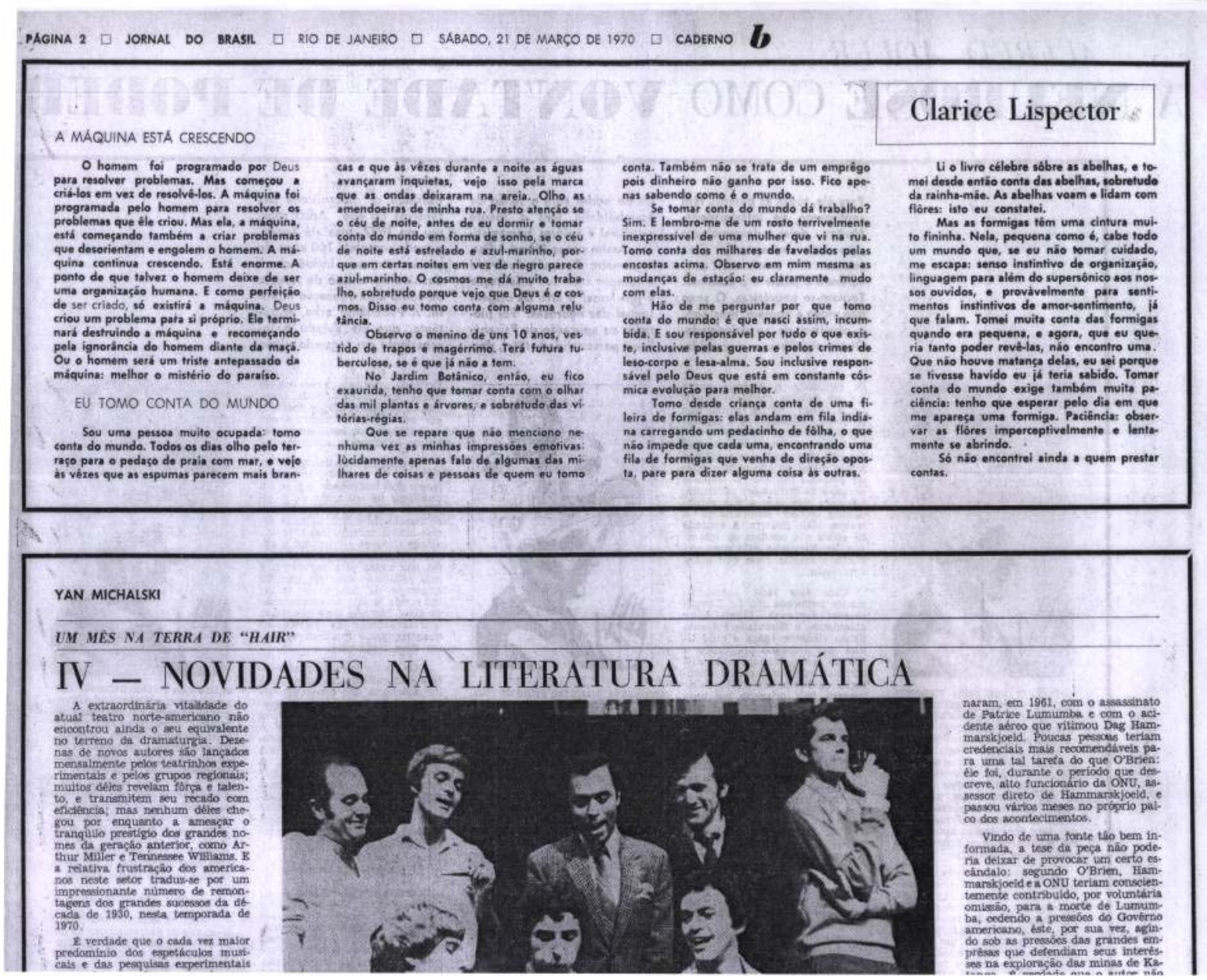




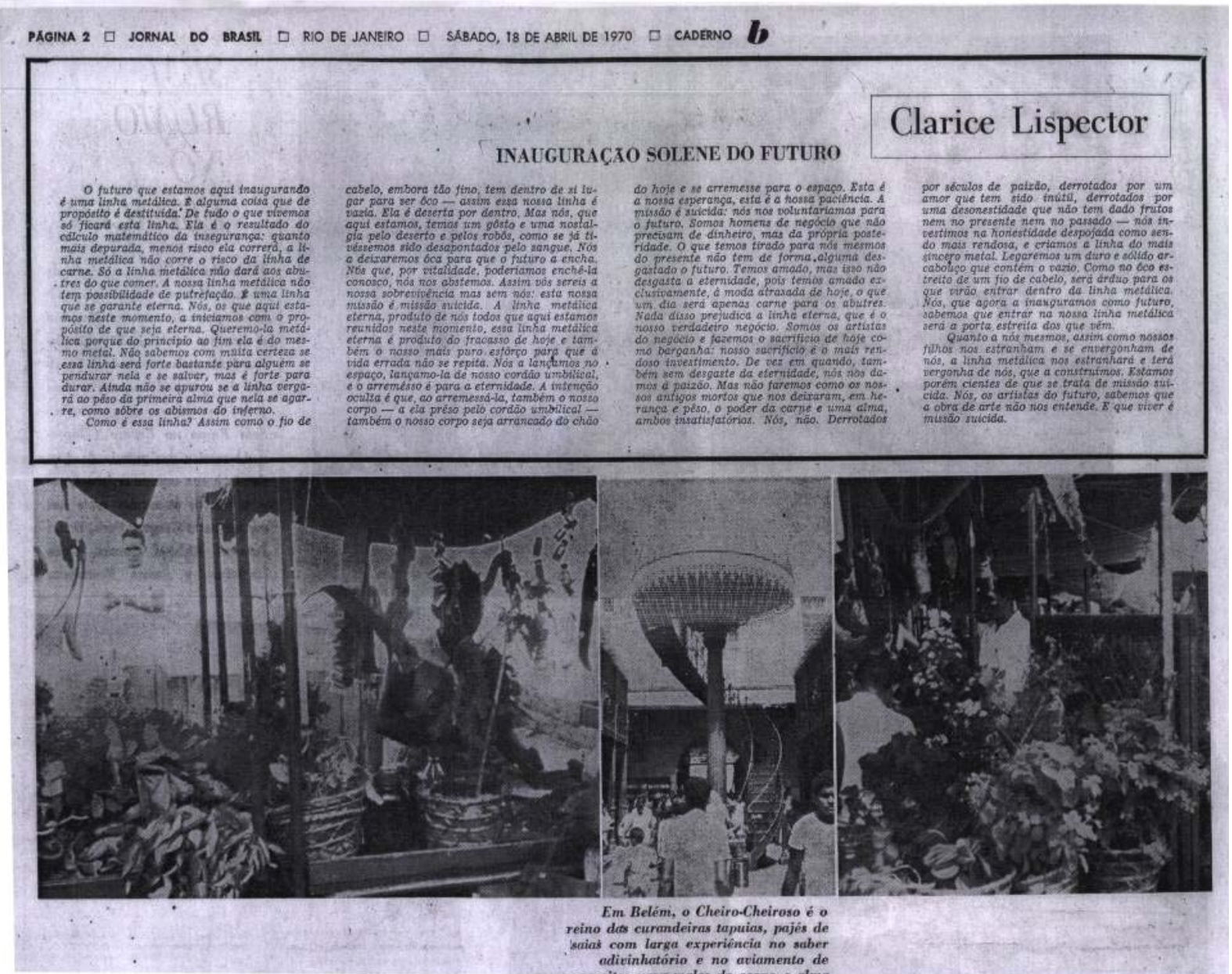


PAGINA $2 \square$ CADERNO B $\square$ JORNAL DO BRASIl $\square$ Rio do Janeiro, sabbado, 20 de fevereiro de 1971

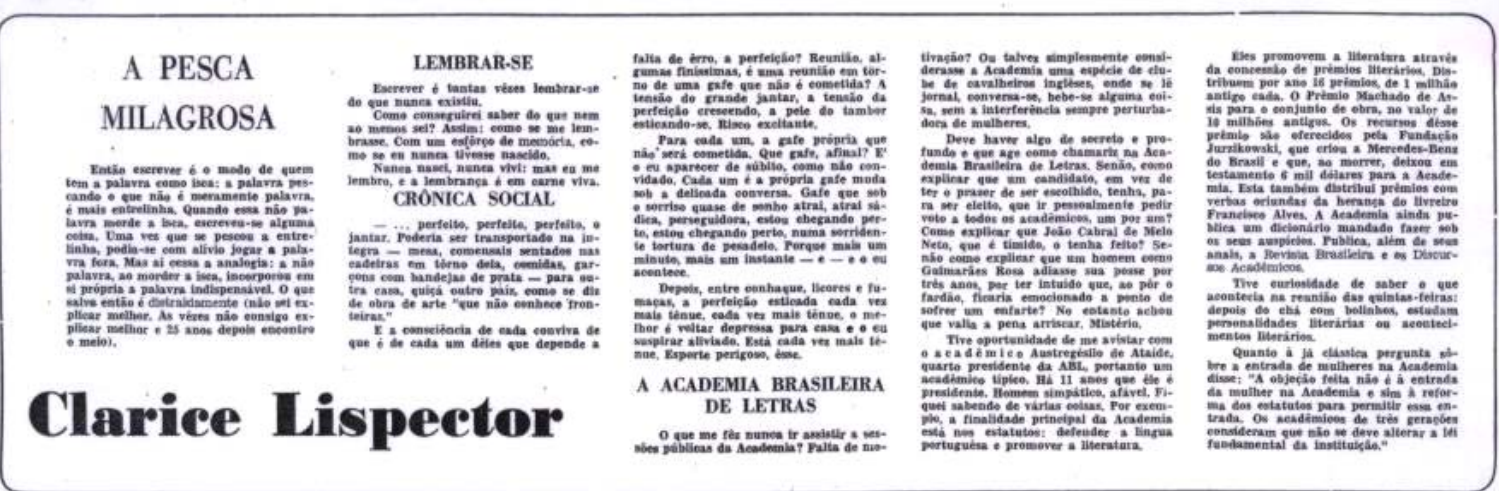

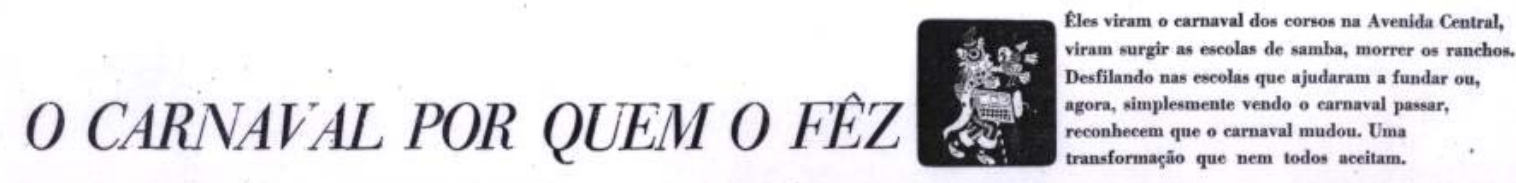

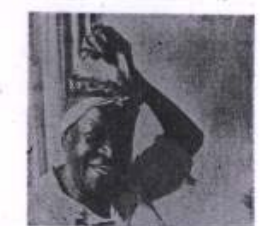

CLEMENTINA DE JESUS

"Eu gostava muito mesmo é de colocar minha baiana"

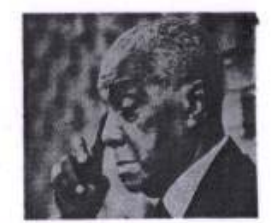

JOAO DA BAIANA

"Hoje também é bom como antigamente"

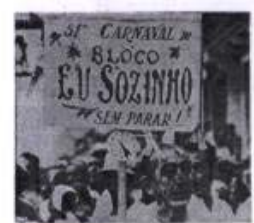

Jôto sitva

"O earnaval de hoje é puramente comercial"

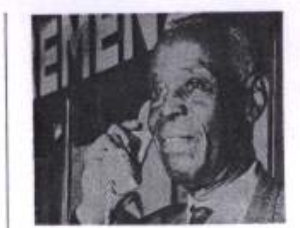

DONGA

"A grande verdade é que ninguém samba mais"

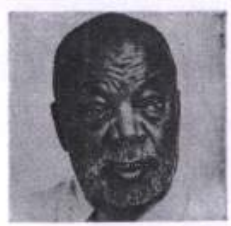

MANO ELOI

"Estou doente mas não deixei de ser carnavaléseo"

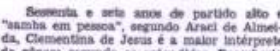

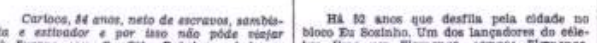

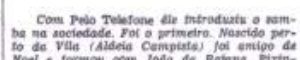

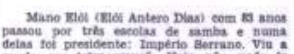

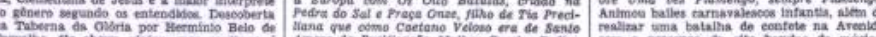

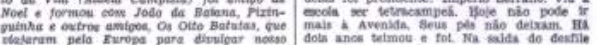




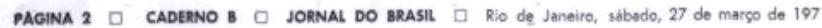
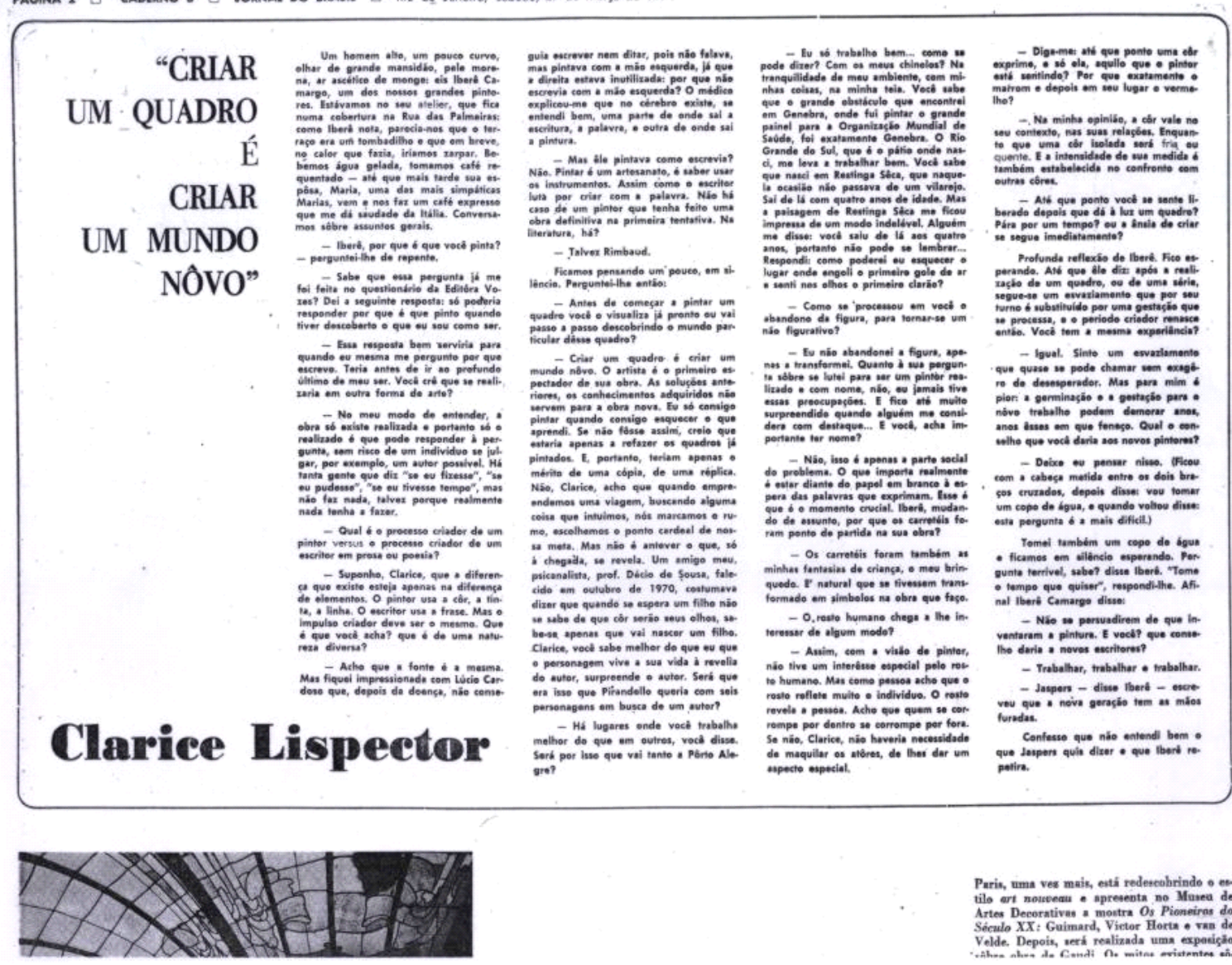

Parik, uma ves maik, esti redescobrindo o es: tilo ert nosevean : apresenta no Musea do
Artes Deeorativas $:$ moutra Os Pioneiros do do

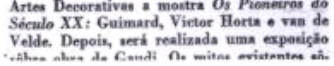


PAgINA 2 CADERNO 8 JORNAL dO BRASIL C Rlo de Jameiro, sábado, 23 de outubro de 1971

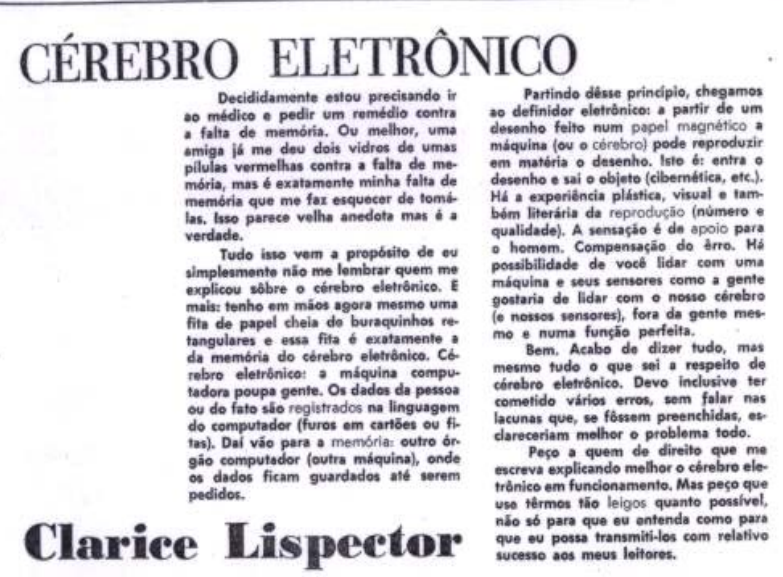

Quando penso que cheguel, th. do cirebro sletrónice, só posso dizer Maria!

Mas o amor 6 mais misterioso do

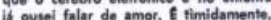
6 audaciosamente, que ouso falar sobbre a mundo.

O meu próprio mistério Sondo.

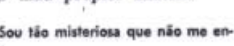

Peẹo licenģa para existir Por coincidância, five e tonho ami.
que sio ou foram analisadas pelo gas que sáo ou foram analisadisto

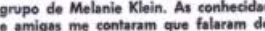
mim a ólo. E imaginei como o Dr. Lou tival deveris estar farto do ouvir mev

das estibve aqui em casa o resolvi, como compensasaja ao desgasto dos ouvidor contos, Locos de Familia. Na dedicattoria

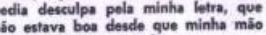
náo estava boa doscle que Dias depois a mốa spareceu am guntei-the se havis entrogue of livro ac sera. E fiquei sabendo que, ao ler

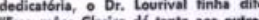

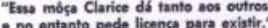
Sim, Dr, Lourival. Poso humilda mento uma alogria, uma oşäo de gra tio experimentada pelas experiétecias isperas, peso a homens o mulheres que deconsiderem um sor humano digna do Peģo a benç̧io do vide.

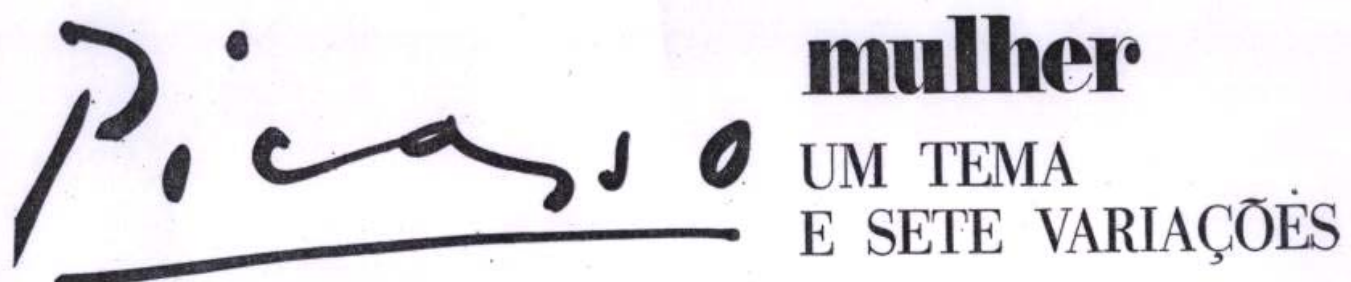

“A arte nunca é casta. No fundo no fundo não existe nada mais que amor, seja de que tipo fôr." Estas palavras de Picasso equivalem a uma profissão de fé e ao mesmo tempo tradusem sua paixão terrena pela exaltação dos sentidos. Por isso, as mulheres - nāo como mitos, mas como imagens do cotidiano, amadas e representadas por seu espirito criador - náo podem ser separadas de sua vida e obra

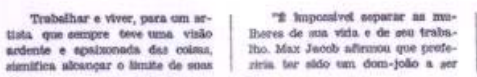


CADERNO B $\square$ JORNAL dO BRasit $\square$ Rio do Jeneiro, sabado, 30 de outubro de 1971 p PAGINA s
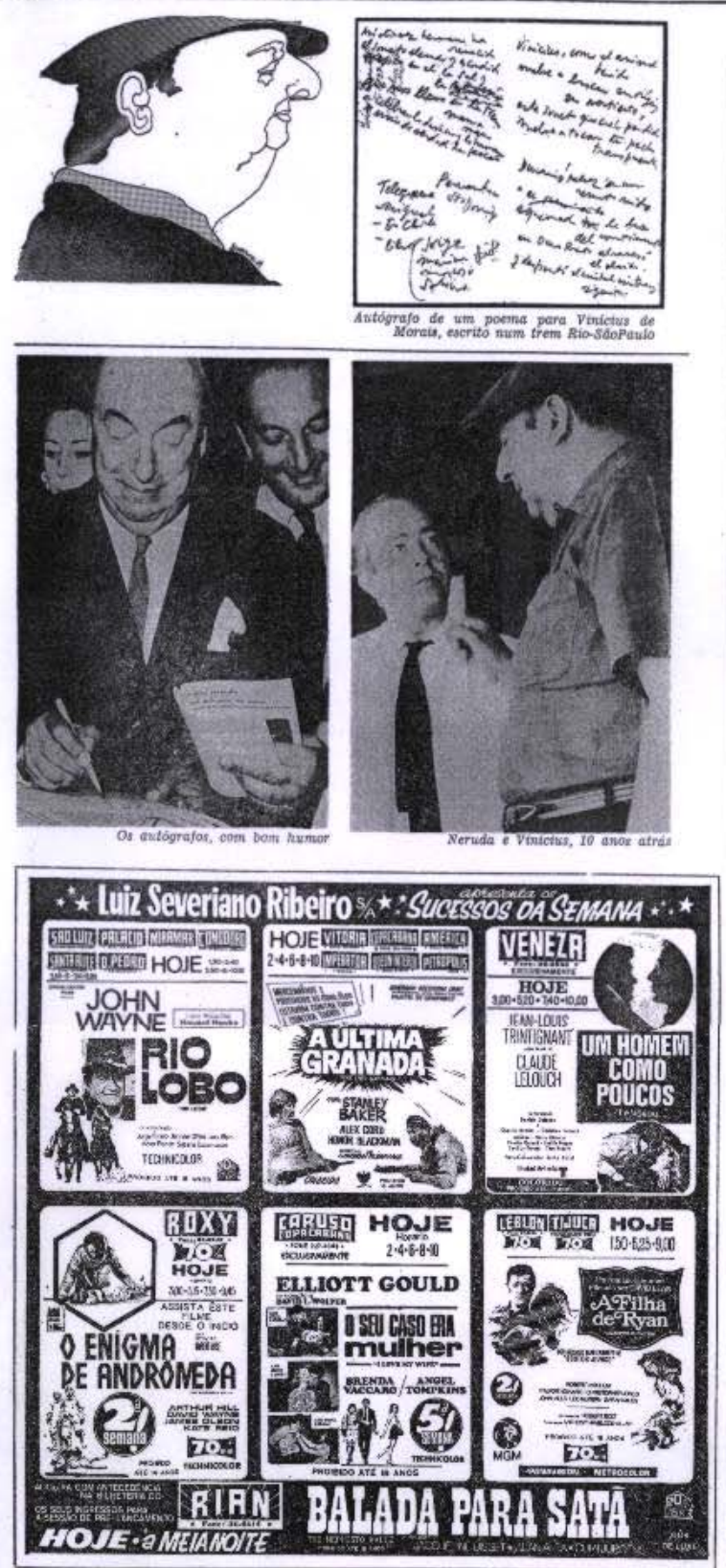

\section{Clarice Lispector}

PRÊMIO NOBEL

DE LITERATURA NO RIO

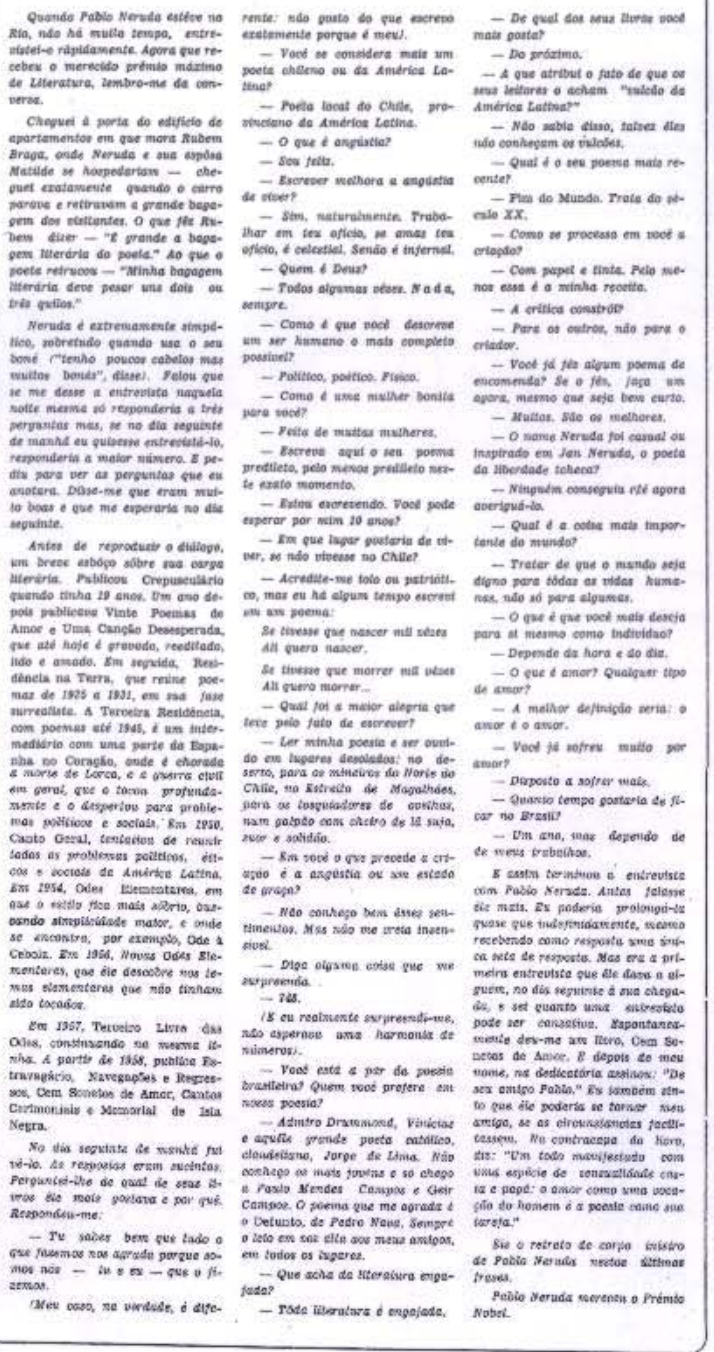

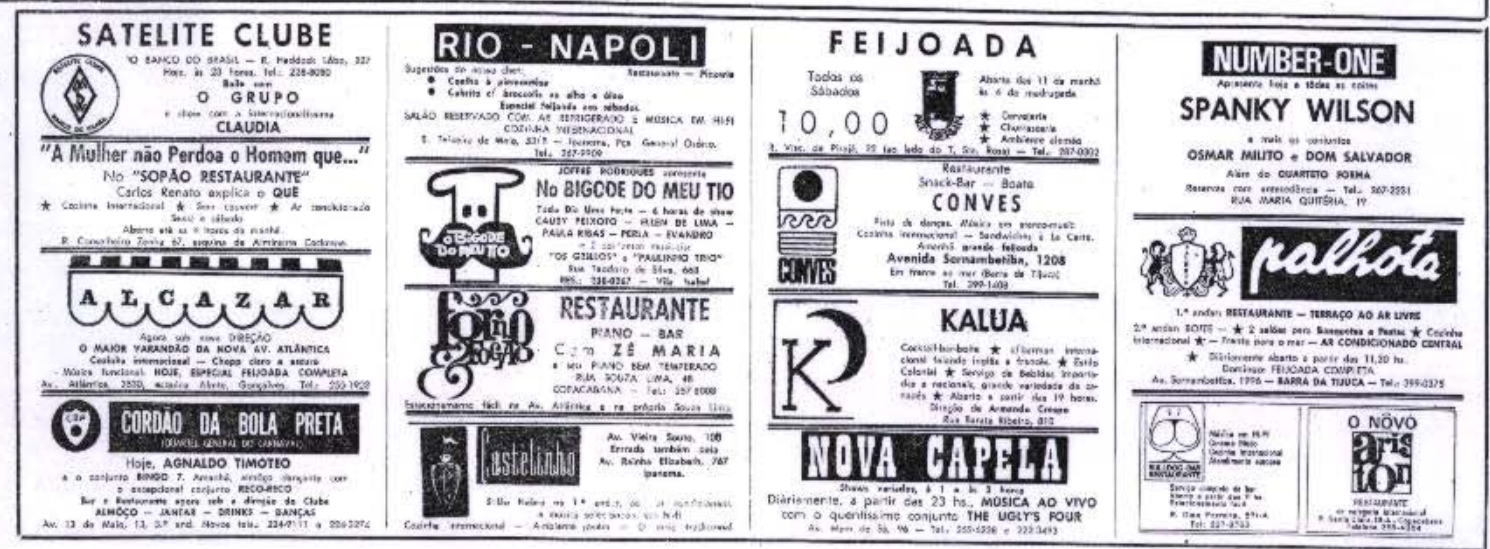



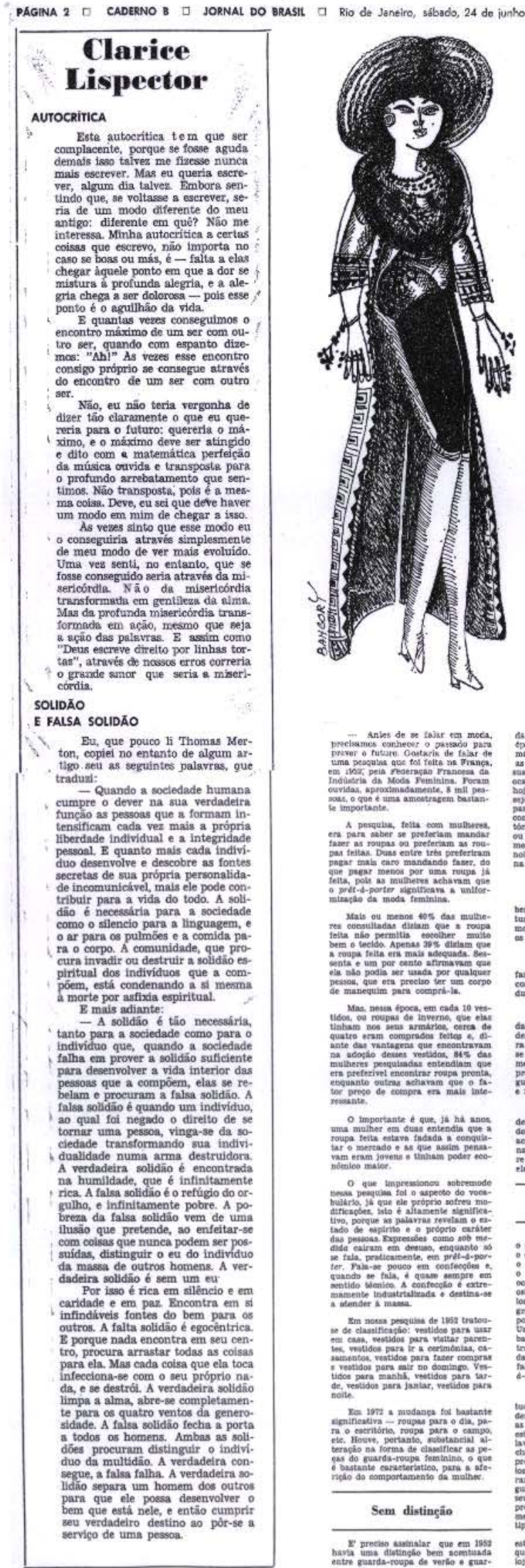

AS

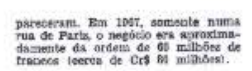

ABERTAS

DA

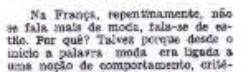

JANELAS

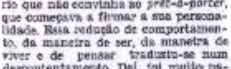
政

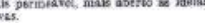

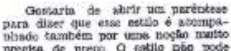

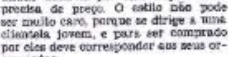

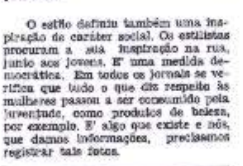

MODA as Motivaçóes de

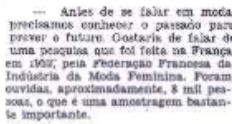

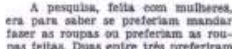

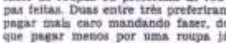

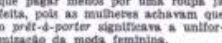

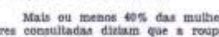

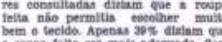

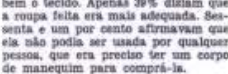

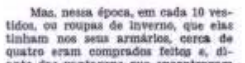

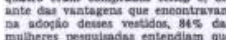

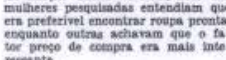

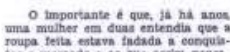

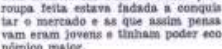

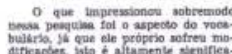

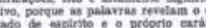

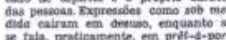

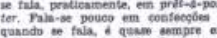

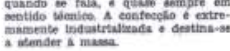

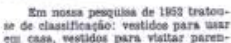
im

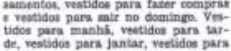

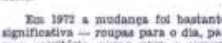

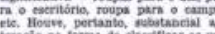

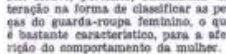

Sem distinģäo

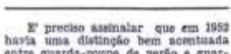

Durante o I Serninário de Comercializaşäo da Moda, realizado em Sbo Paule, a francosa Ginette Sainderichin, jornalista - diretora de moda das revistas Group Avant-Premiere, fer uma palestra sobre. tema A Evoluçäo Sociológica da Moda o Compra no Setor do Vestuário

0 vestido de Brigitte

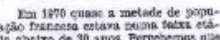
a tion

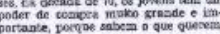

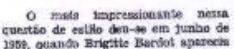

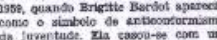

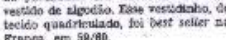

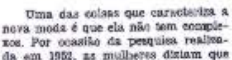

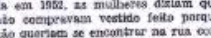

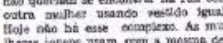

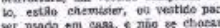

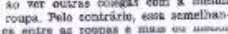

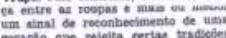

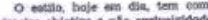

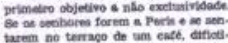

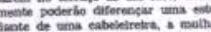

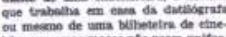

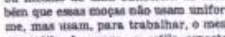

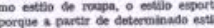

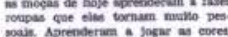

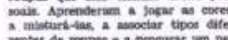

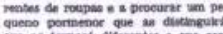

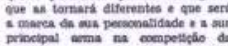
Sereh provibo ver of

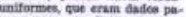

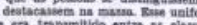

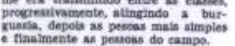

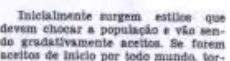

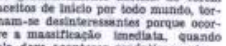

Com surpresa

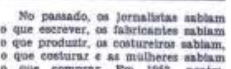

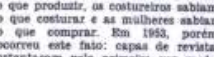

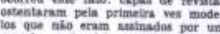
(n)

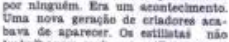

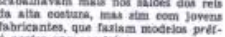

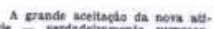

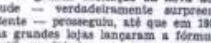

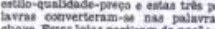
Cans

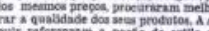

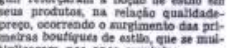

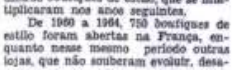

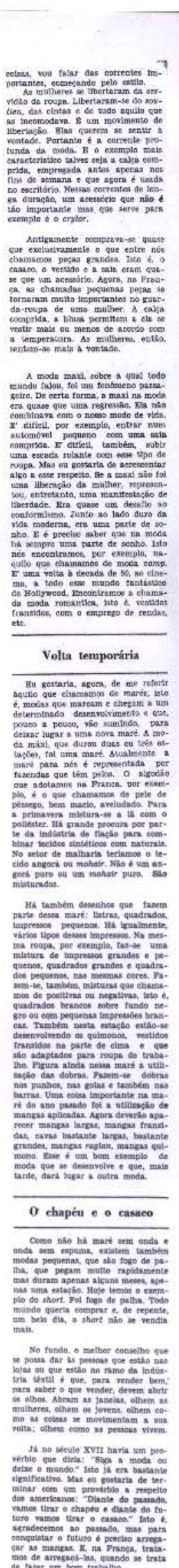




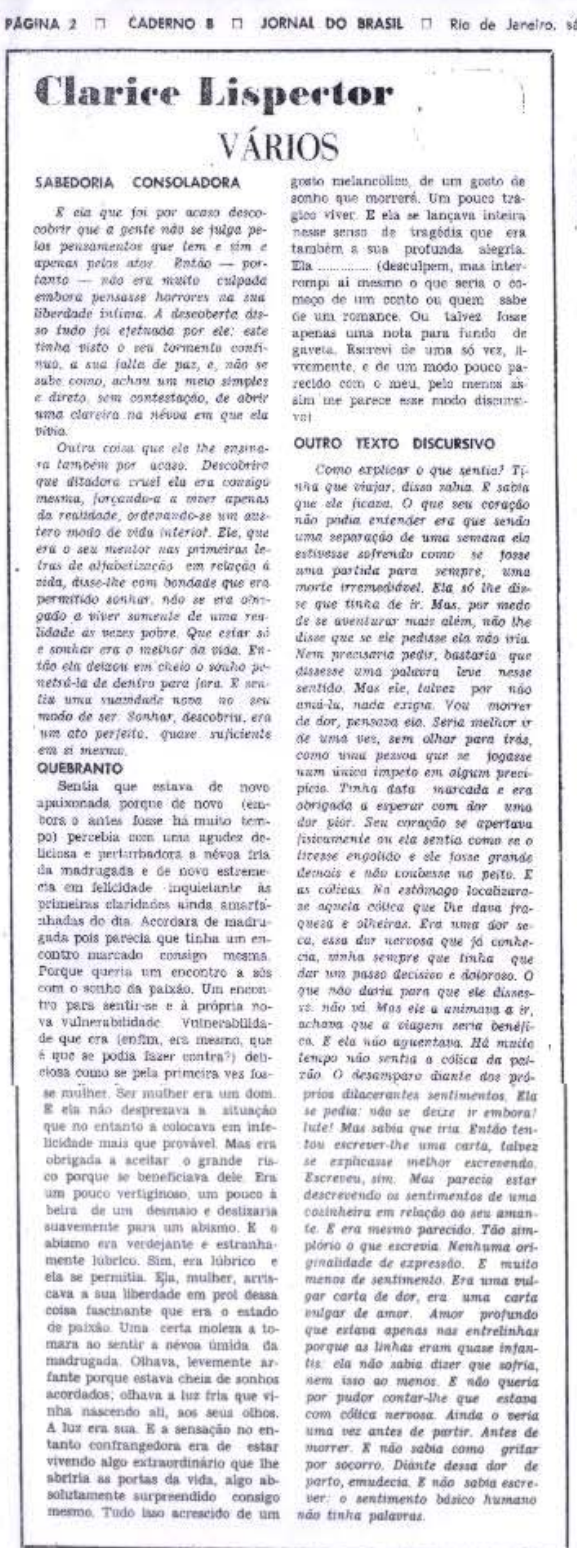

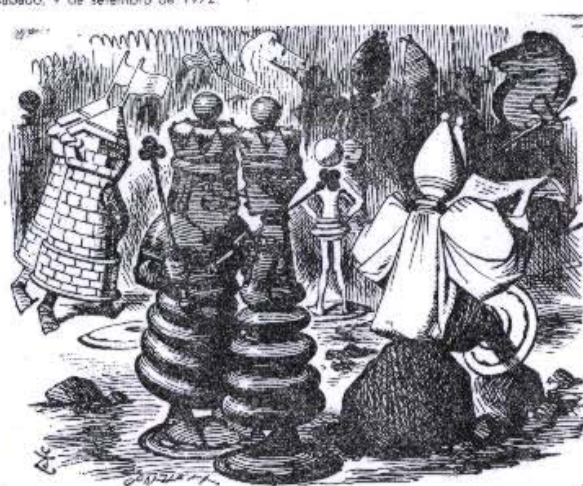
- 0 que eu mais gostic
no xadres é daquele monento en que estithicos atual campeäo Bobby Fischer Para Aliter in Through The Looking Giass and what aice Found There t, nos fir do seculo Xla, o zadrea ifferentec "Dma enorme partida de xadrez está sundo jozada - sobre todo o nundo se isto te reahente um mundo... Que colse engraçada! Cotuo eu gostaria de ser um deles! Be eu pudesse entrar no jogo, náo me importaria de ser um mero peäo, embora, éc claro,

\section{FISCHER E ALICE: VOCES QUEREM JOGAR XADREZ?}

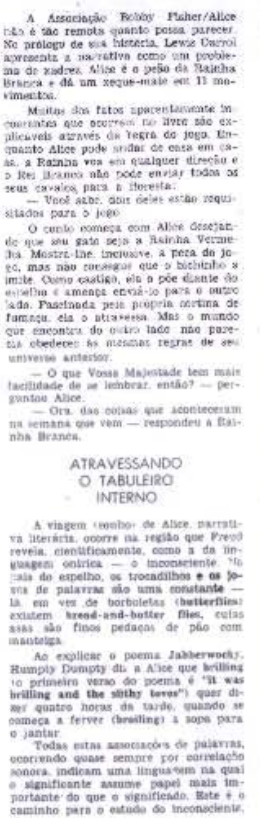

DANUSIA BARBOSA

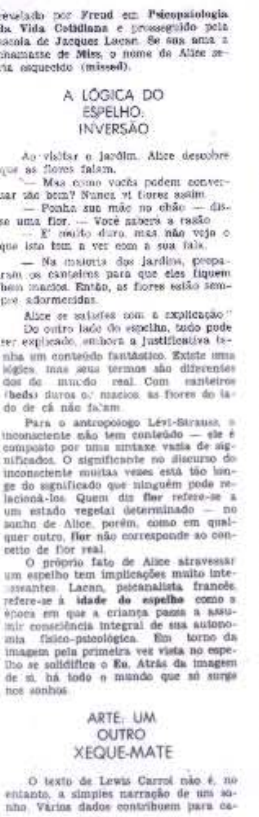

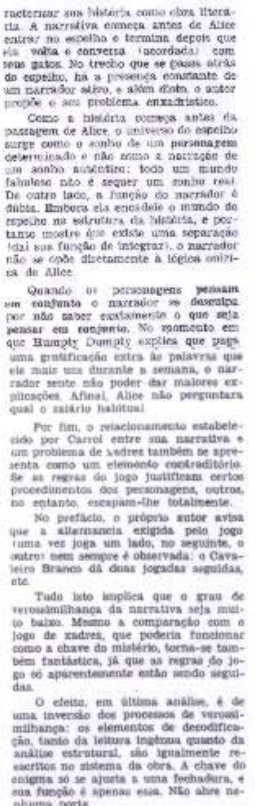

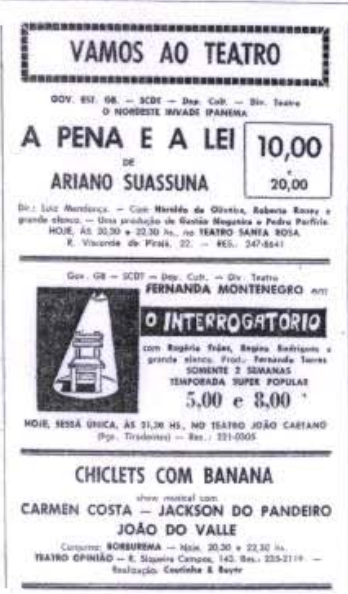

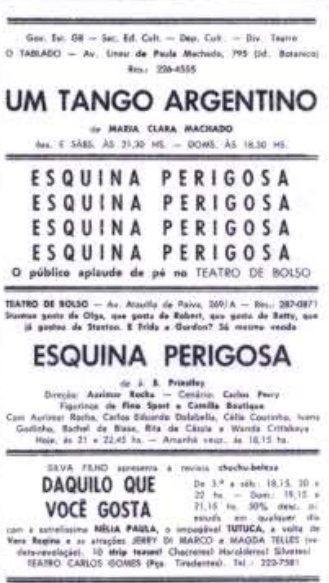
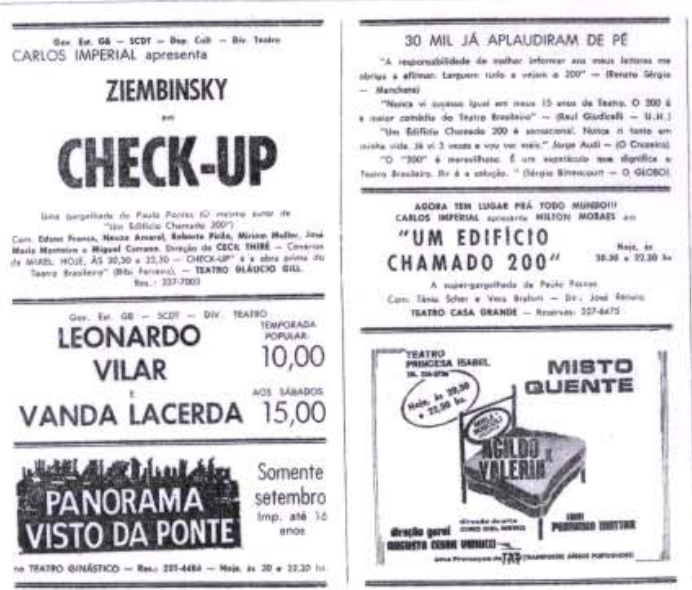
Clarice Lispector / UMA TARDE PLENA
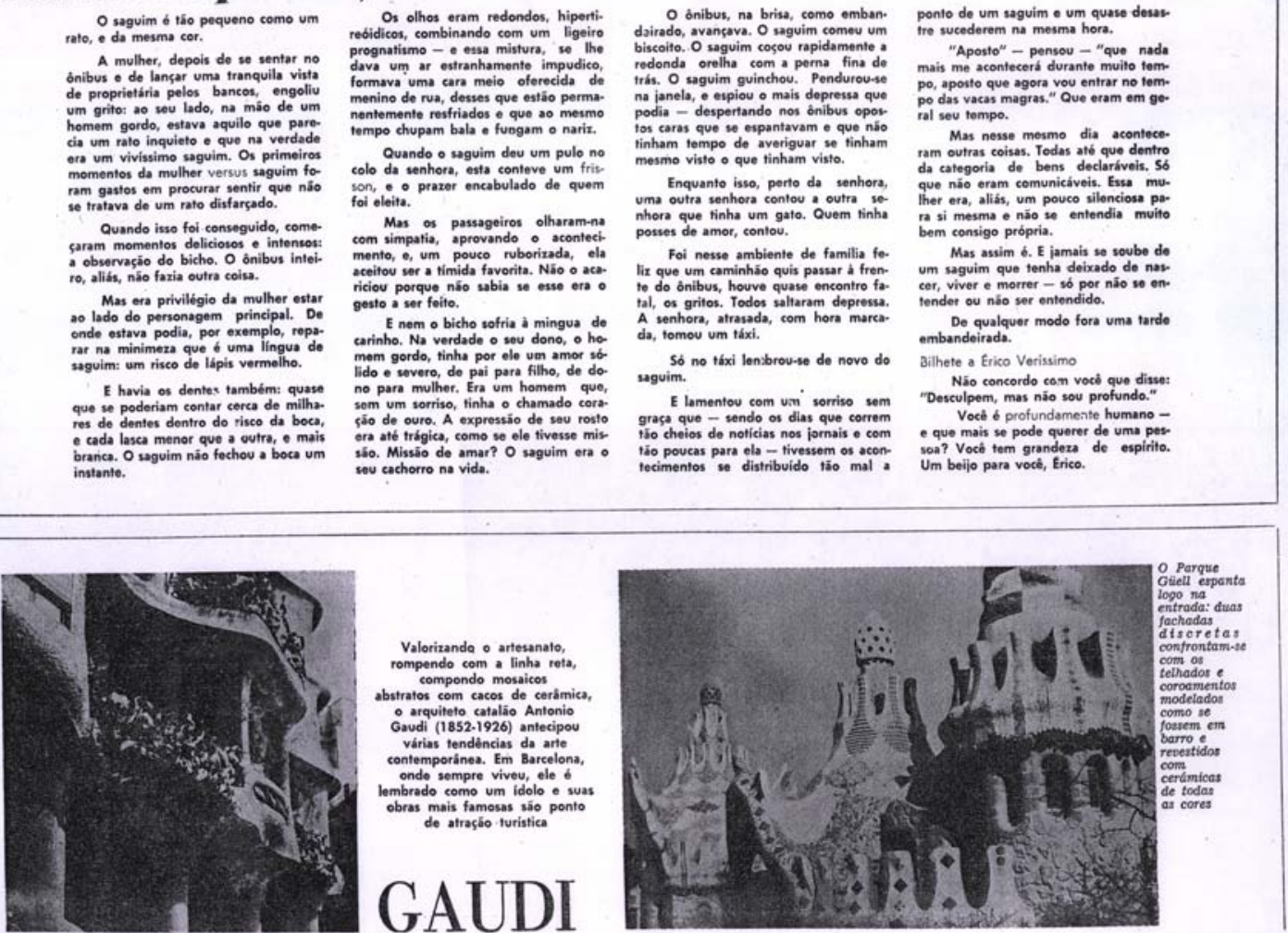


\section{Clarice Lispector}

O ARRANJO

Ela era cria da casa-grande, des-

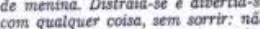
era alegre. Andava de corpo solto a dona da casa estava irada, chamava-a de debol mental. Diziam que qualquer homem a teria, se quiseses. Entâo os patróts, realmerte cansado de distribuir por famillias os seus thDhos, a injuriavam. Nä́o usavem vio-
léncia porgue por principio nä́o eram lencia porque por principio náo eram
violentos, Mas se ela almocava, diziam: éclaro, a fome duplicoul. deut o apetite. Mandapam-na trabe teas do tempol je arrumemos com que
familia esse ai vai ficarl" Ela näo

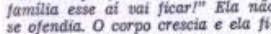
cava cada vez mals amarela sob a cor de mulata quase branca. O que os patróes não perdocvam é que dessu ven
tivesse acontecido com um "negro tivjost" como se eles tivessem para ela pranos de um homem menos negroe
mais limpo. As veres, quando ela pas. tom velado por cause dos netos prepareceu compreender melhor e diste masito alto: mas foram só trés vezes As crianças exultaram feitzes, or pel. pouca vergonha, expulsaram-na da
sala - ainda por cima tropecous no tapete e cuiu sobre a bandeja. Mas

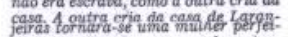
ta para esidar das roupase das crian. cas, uma verdadeira escravia. Mas ela näo era escrava: vivia independente
deleses e dava dे luz as seus próprios fideles e dava di luz as seus proprios tiamareladas como a mäe.

Dois anias depois encontrei-a na cato que vivia com um portugues. "Estou agara mesmo esperando por costada no poste. Ele afinal apareceut na curva da essuina: velho, e era por :sso que ela néo estava grivida, par. mim", disse, como se explicasse tudo. Ble se manteve a curta distancia, ouvisa a frase e ebeixou os othos, escid

Em busca do outro

Não $\dot{E} d$ toa que entende os que e o sell. E cono hoje busca com sojreguidao e aspereza o seir meihor ousa mais falar em caminho. Ele que tinha querido o Caminho com letre te d procura de um modo de andar. de um passo certo. Mas o o atallh ocom sombras refrescantes e reflezo de luz enta finalmente ele mesmo, isso nāo

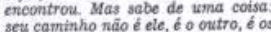
outros. Quando puder sentir plena. to de chegada.

$E$ amanhã é domingo

Born domingo para nós. Segun-
feira é um dia mais dificll porque sempre a tentatita do combeco de noite um revellllon modesto, pois se meia-noite de domingo nao e comers rova, o que significica fazer planos $e$ fabricar sonhos. Meus planos se re.
numem, para esta semuana nova, eet numem, parin esta semana nova, em.
arrumar finalmente mets papeis Quanto cos sonhos, deserul pem, guar. lo-os para mim, como voced guar.
dam, oom o ouhar pensativo, de quetr dam, comt o oher pensatios
tem direito, of próprios.
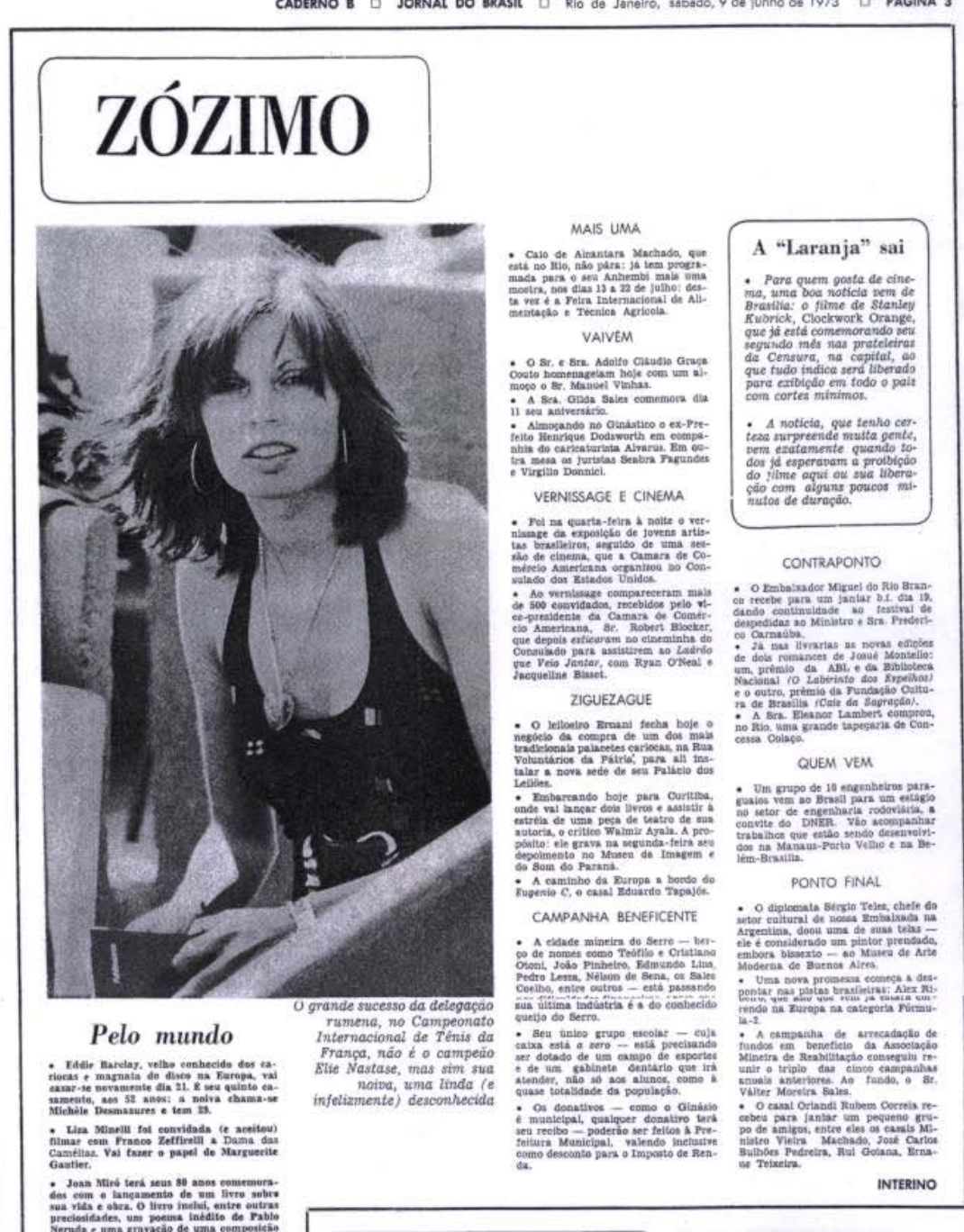

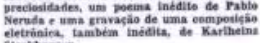

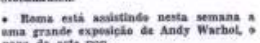
A inpreana trancess apsianta mundos

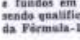

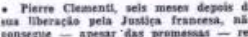

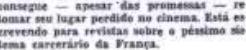

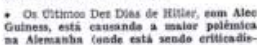

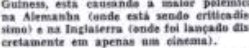

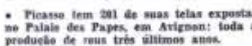
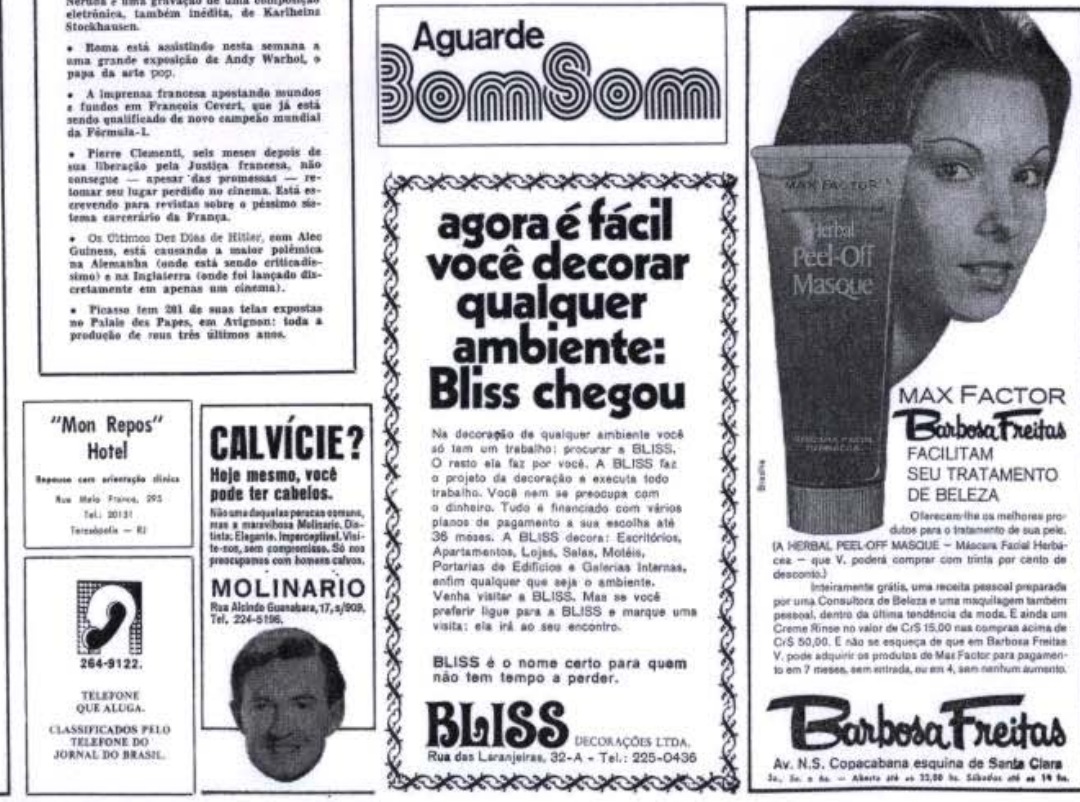
PAGINA 2 CADERNO B IORNAL DO BRASI D Rio de Jeneiro, stbado, 10 de nevembro de 1973

\section{Clarice Lispector}

\begin{tabular}{|c|c|}
\hline 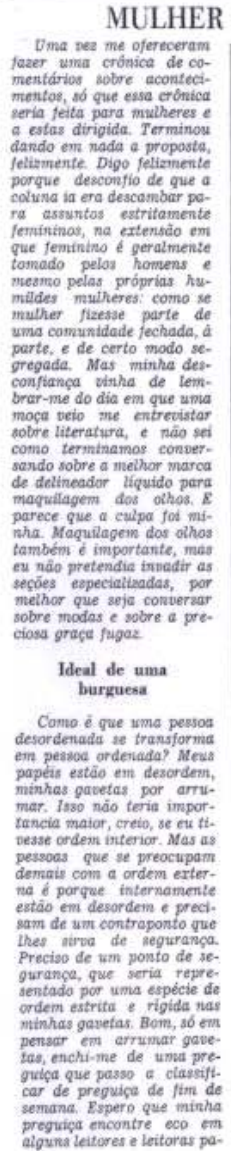 & 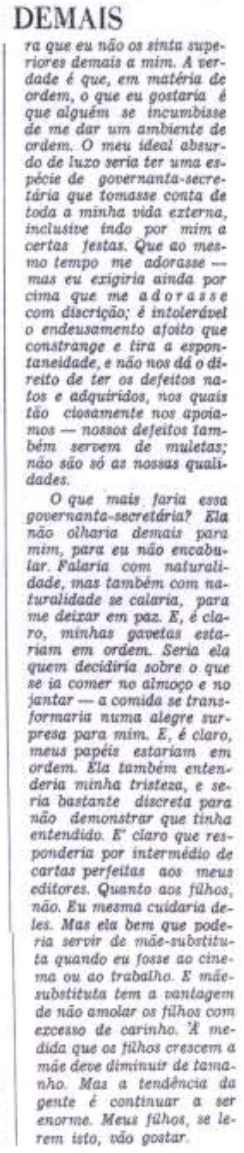 \\
\hline
\end{tabular}

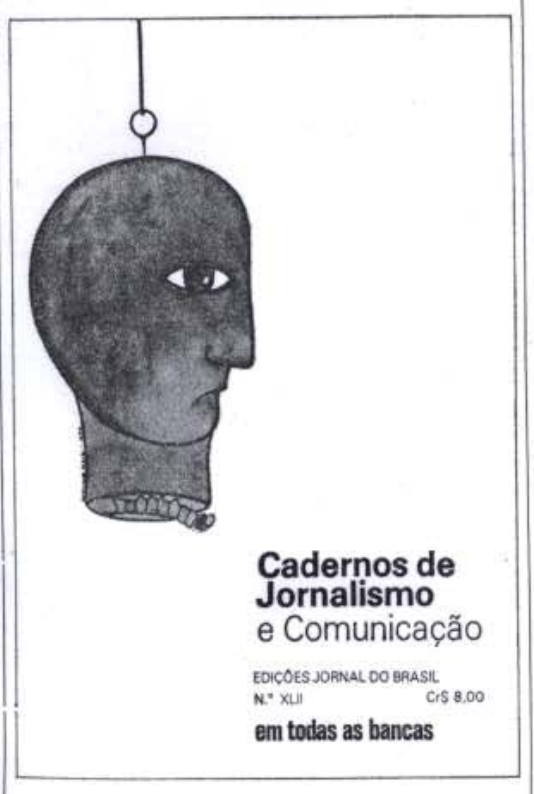

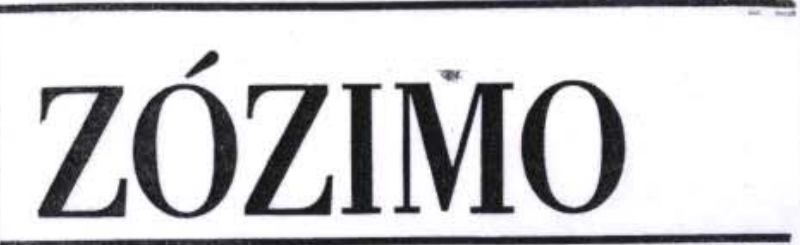

HUMOR BAIXO NÍVEL

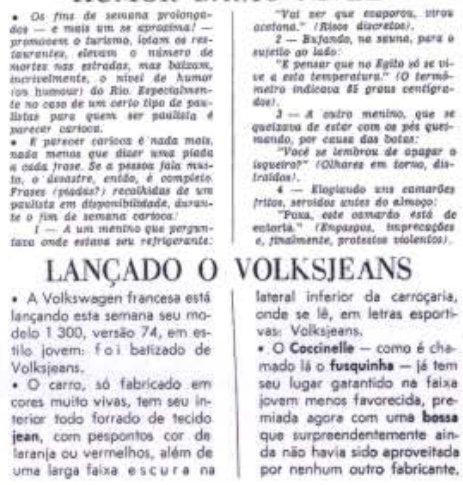

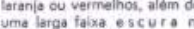

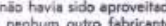

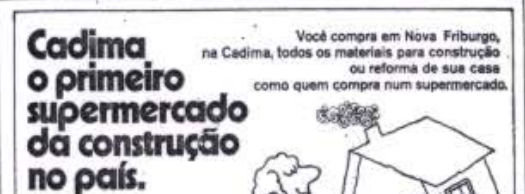
no país.

Progreme um fim-ce-semiana na

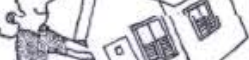

rory cadiuna

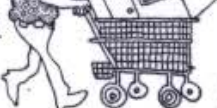

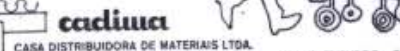

Nova Frigurgo - en
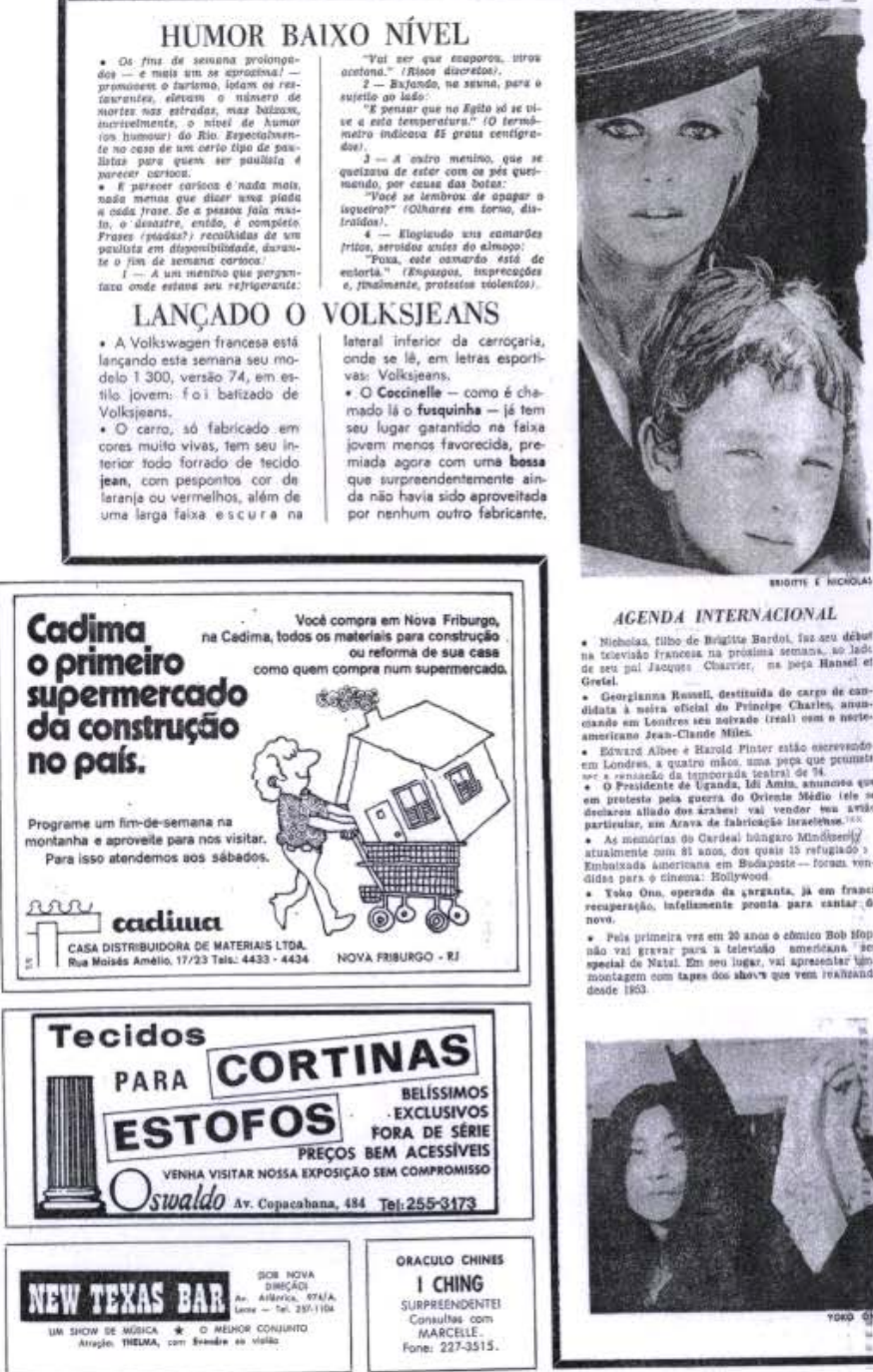

AGENDA INTERNACIONAL

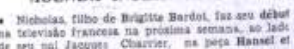

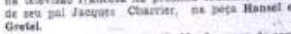

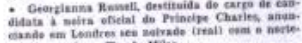

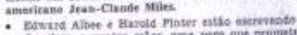

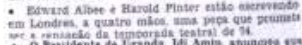

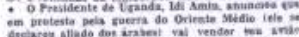

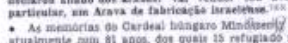

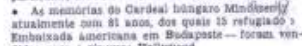

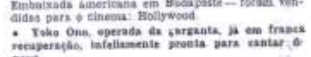
neceas
nove.

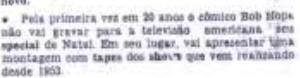
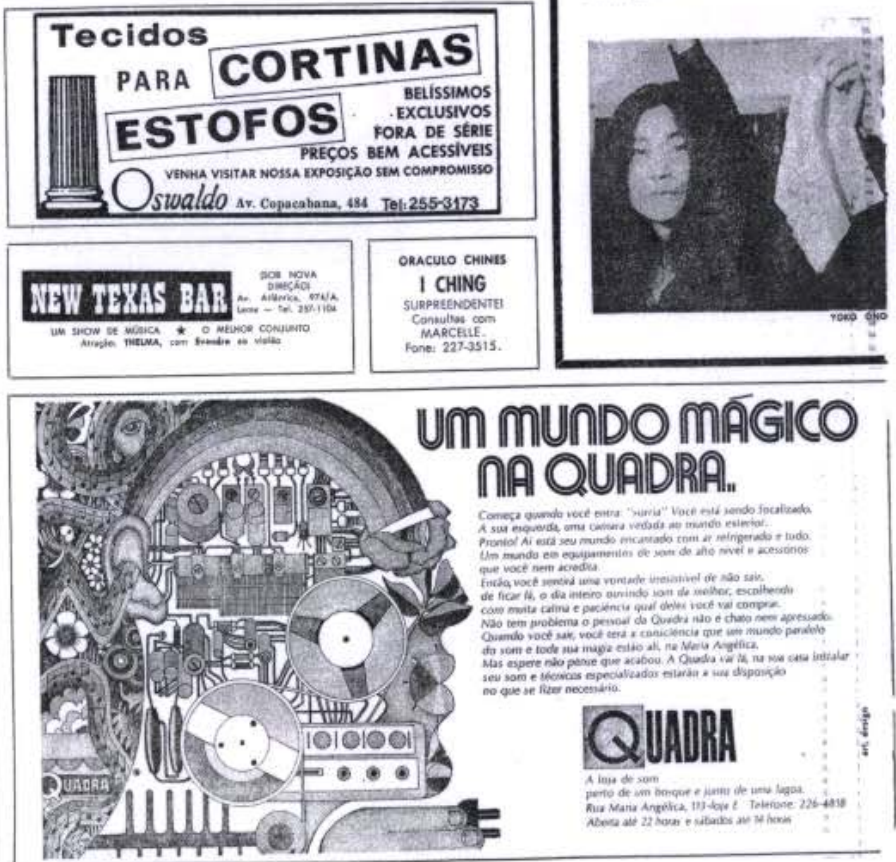
Anexo B Coluna Clarice Lispector, publicada em 7 de outubro de 1967.

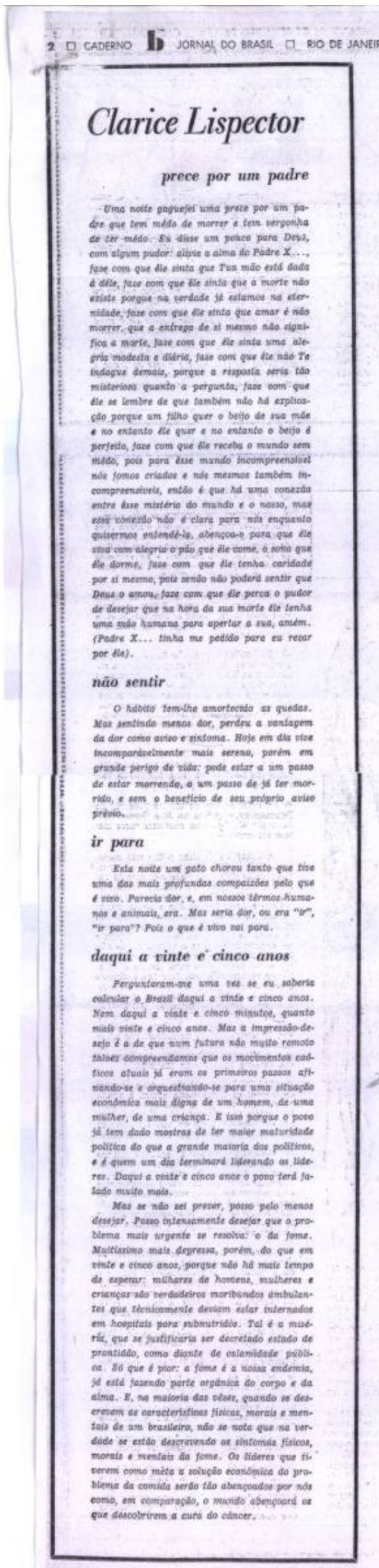

$\underset{\text { jose paulo m, da fonseca }}{\text { A } M A R G E M}$ DA BIENAL

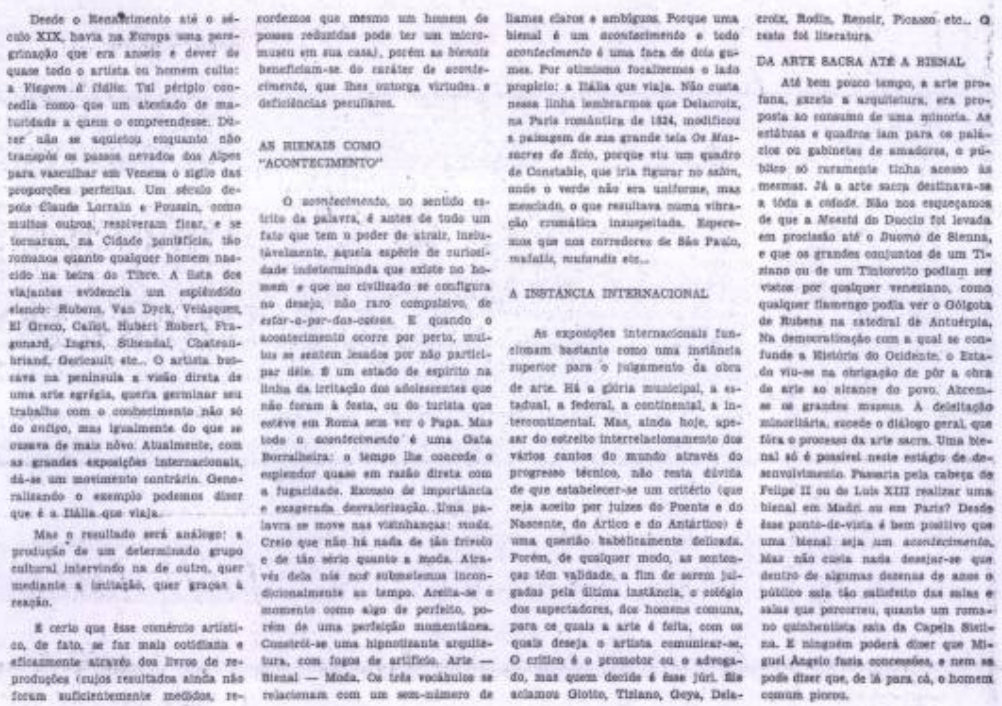

\section{PETROVIC E O NÔVO CINEMA IUGOSLAVO}

wilson cunha

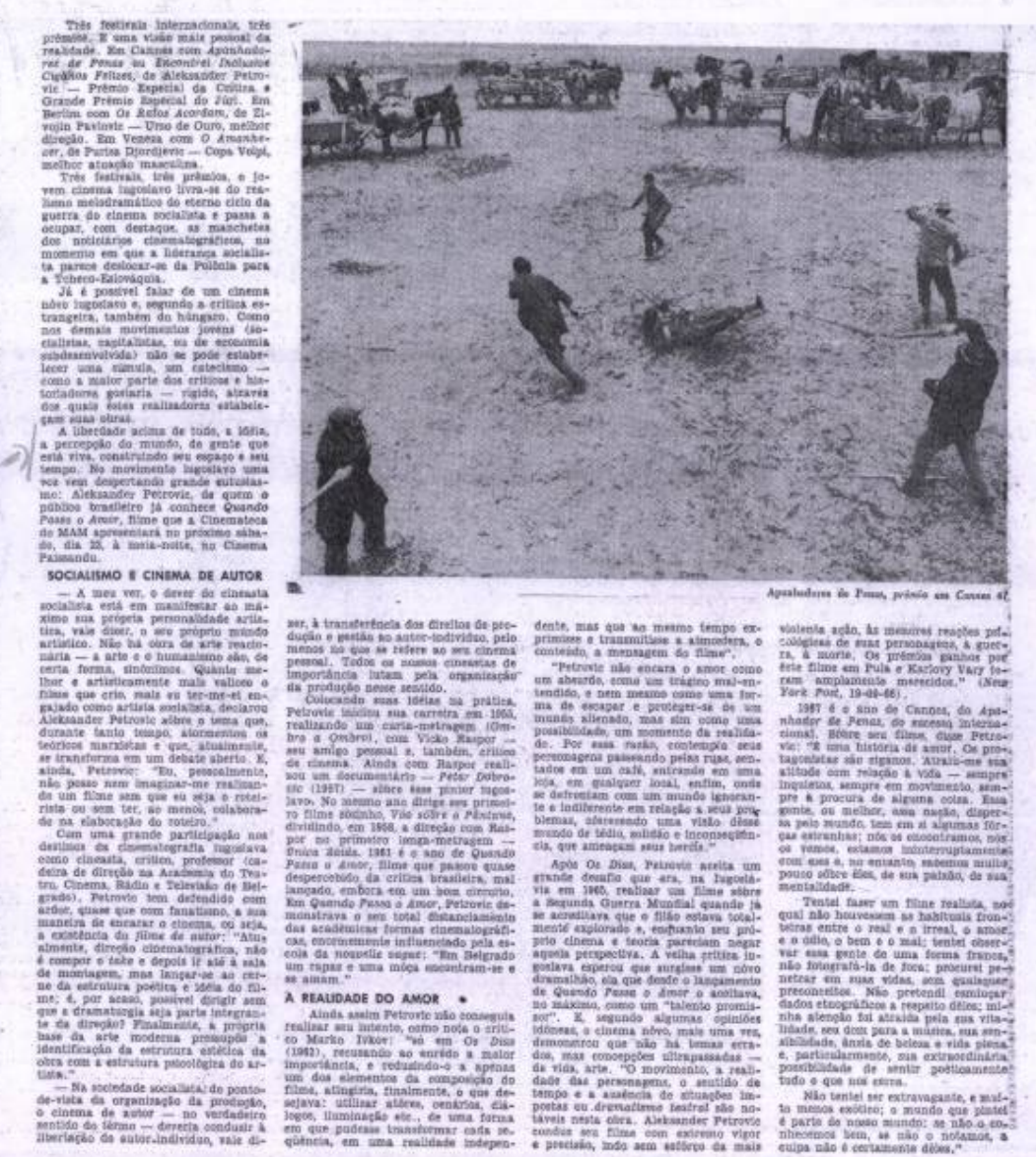


Anexo C JORNAL DO BRASIL. Rio de Janeiro, 7 mar.1967. $1^{\circ}$ Caderno, p.11.

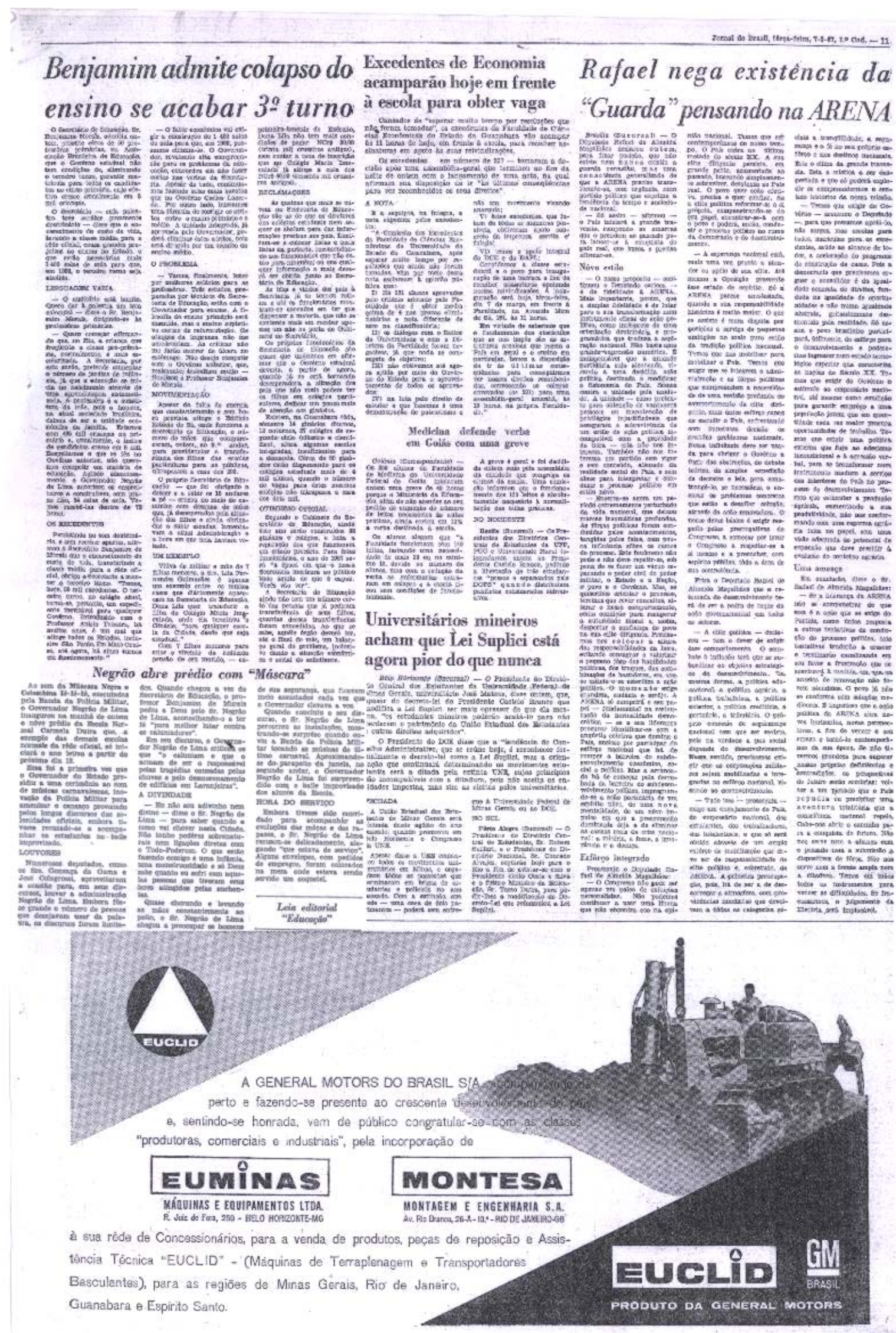


Anexo D JORNAL DO BRASIL. Rio de Janeiro, 8 nov.1969. $1^{\circ}$ Caderno, p.1.

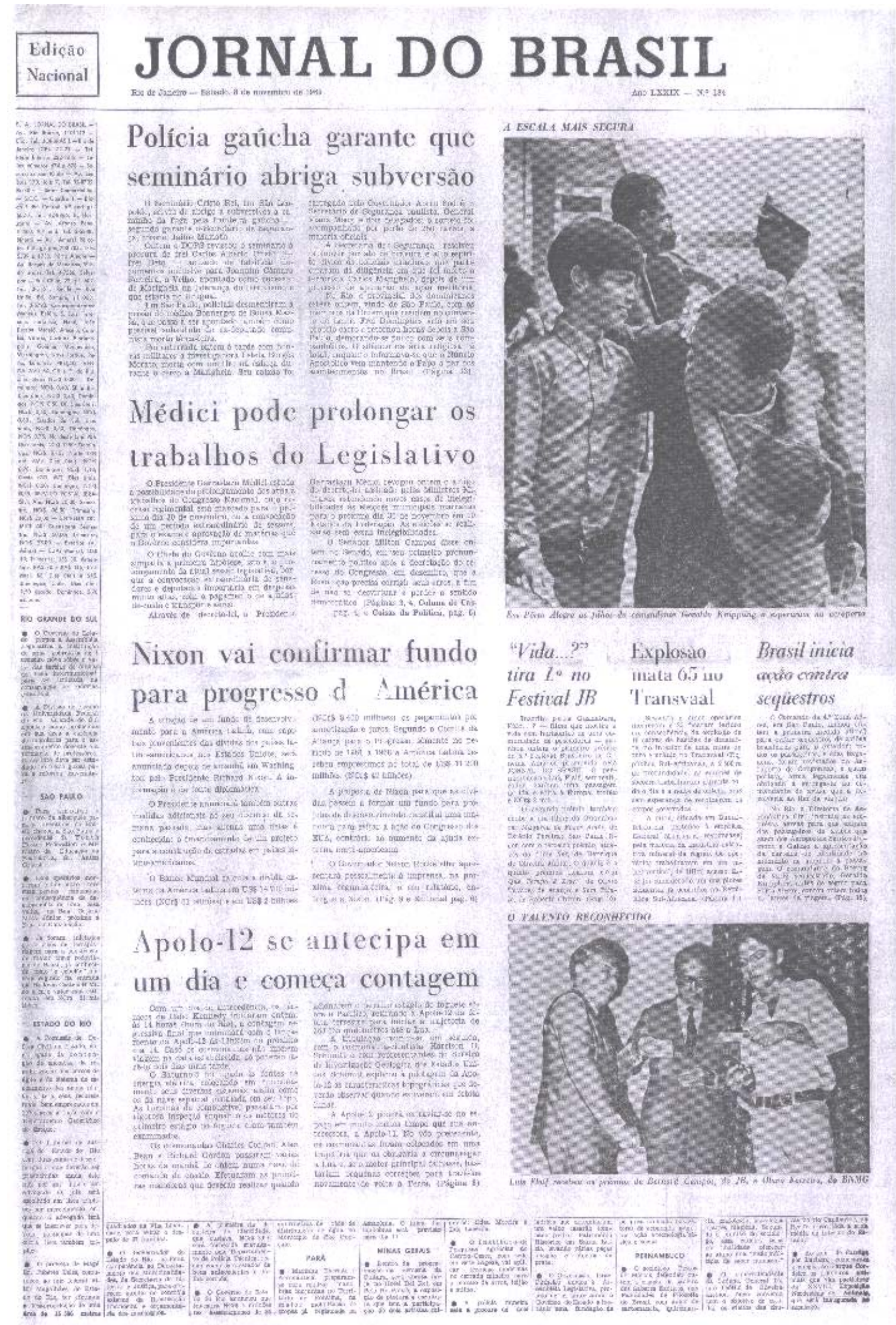


Anexo E JORNAL DO BRASIL. Rio de Janeiro, 17 set.1967. $1^{\circ}$ Caderno, p.1.

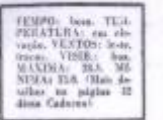

\section{JORNAL DO BRASIL}

O JORKAL DO BRASIT he hoje ciacula com 112 Cademe Expecias, Menita Nasser revela que errou ao acusar Estados Unidos

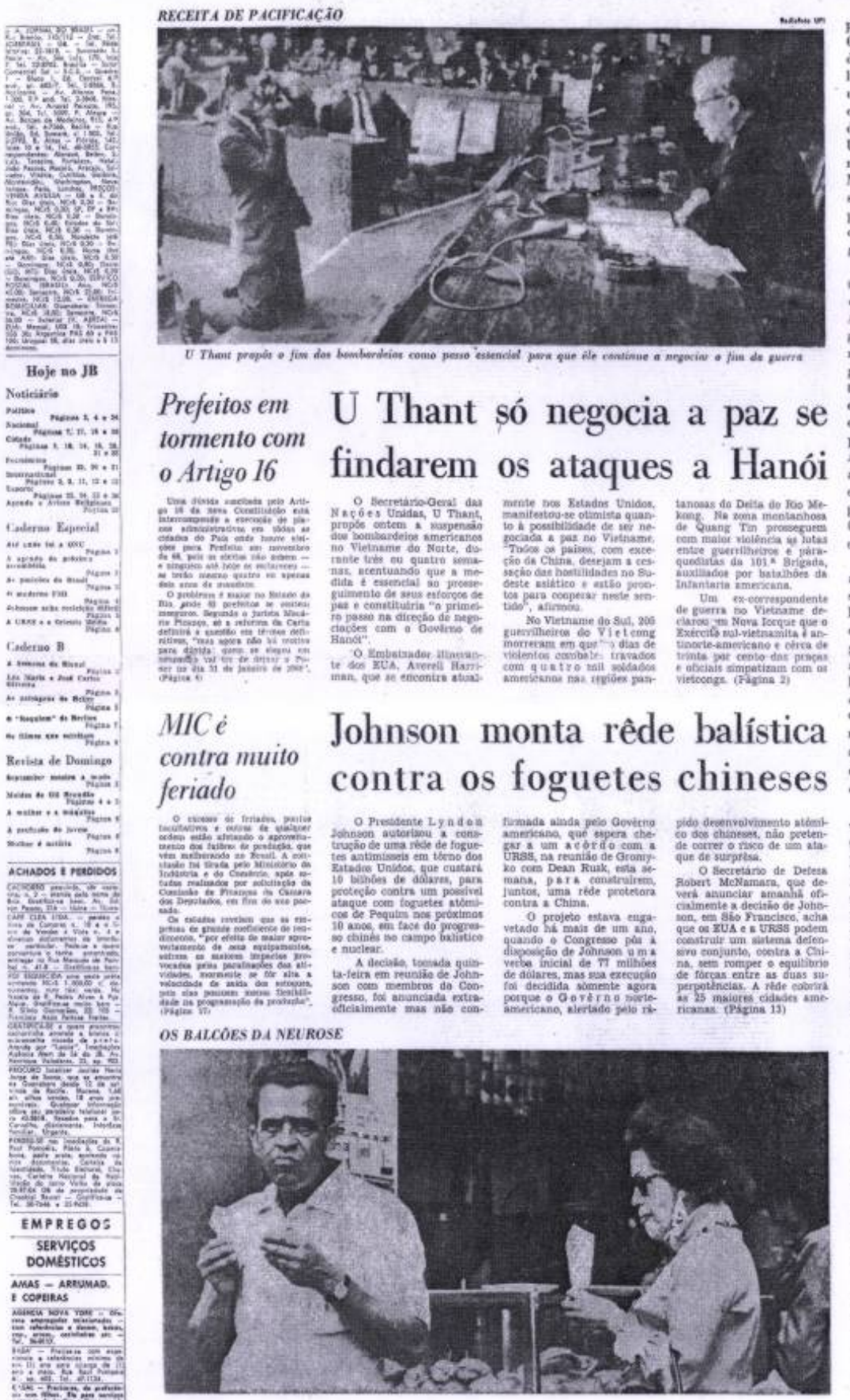

0 Presideute da Re fablica Árnbe Unida, amin Abdel Namer, Cidade está lideres árables, duraste ocupada chailas, que tinha errs. pelos ratos

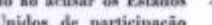
Unitlos de participasáa
on guerra do Oriente. Metio, ao laslo de lerracl, gando ume informe di. ado, gue aeaha de che gar : Paris. 0 portarvox do Minis. trio de Oriestaçăo $\mathrm{Na}$

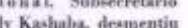
noticia da suposta re mümria de Nasser, dival puda no manhă de onHeira da

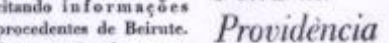
A. commiazeater eatre acaba hoje cria foran interrane a

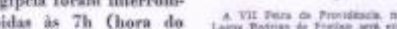
Criente Medio), max ji Embara an apieneias firmem que é ralusa a 19 das exeppionats de te- $=05$

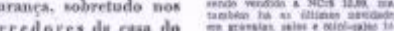
Presidente Naserr, edie.

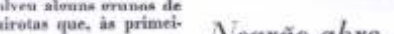
at horas de ontem, se Negräo abre aglomeravam eau tórno o Trevo emil hasea de noticias. ao tráfego vadores polítices acreditam anc a sairitio do Marectual Abdel Hakim Amer, ex-Vice-Pvesidente e ex-Comandante das Förşas Armsdas da RAU, na quinta-feira, to wha desciscadeado una luta pele poder we pais. (Noticiário na page 8 . Elitorial, us pieg. 6)

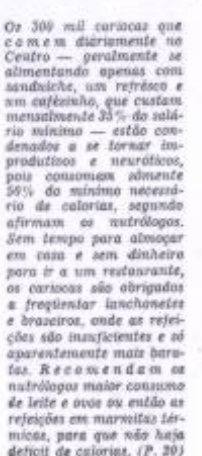

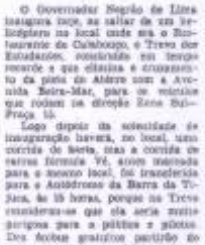
com

\section{UNE perde} força entre estudantes

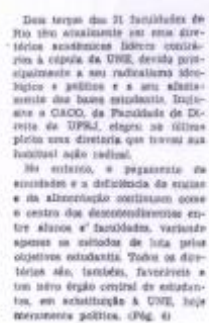


Anexo F JORNAL DO BRASIL. Rio de Janeiro, 17 set.1967. $1^{\circ}$ Caderno, p.5.

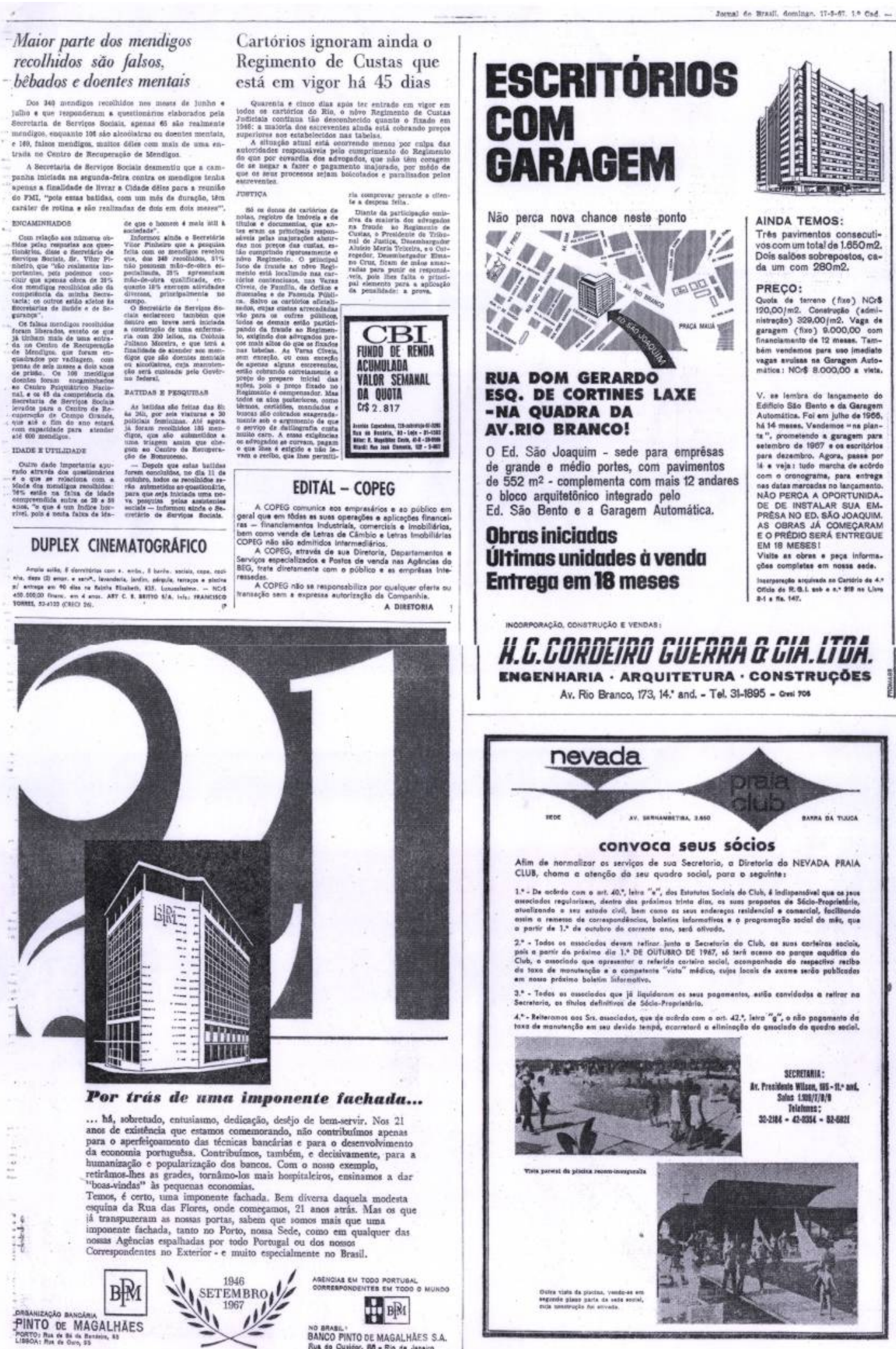


Anexo G Coluna Clarice Lispector, publicada em 7 de outubro de 1967.

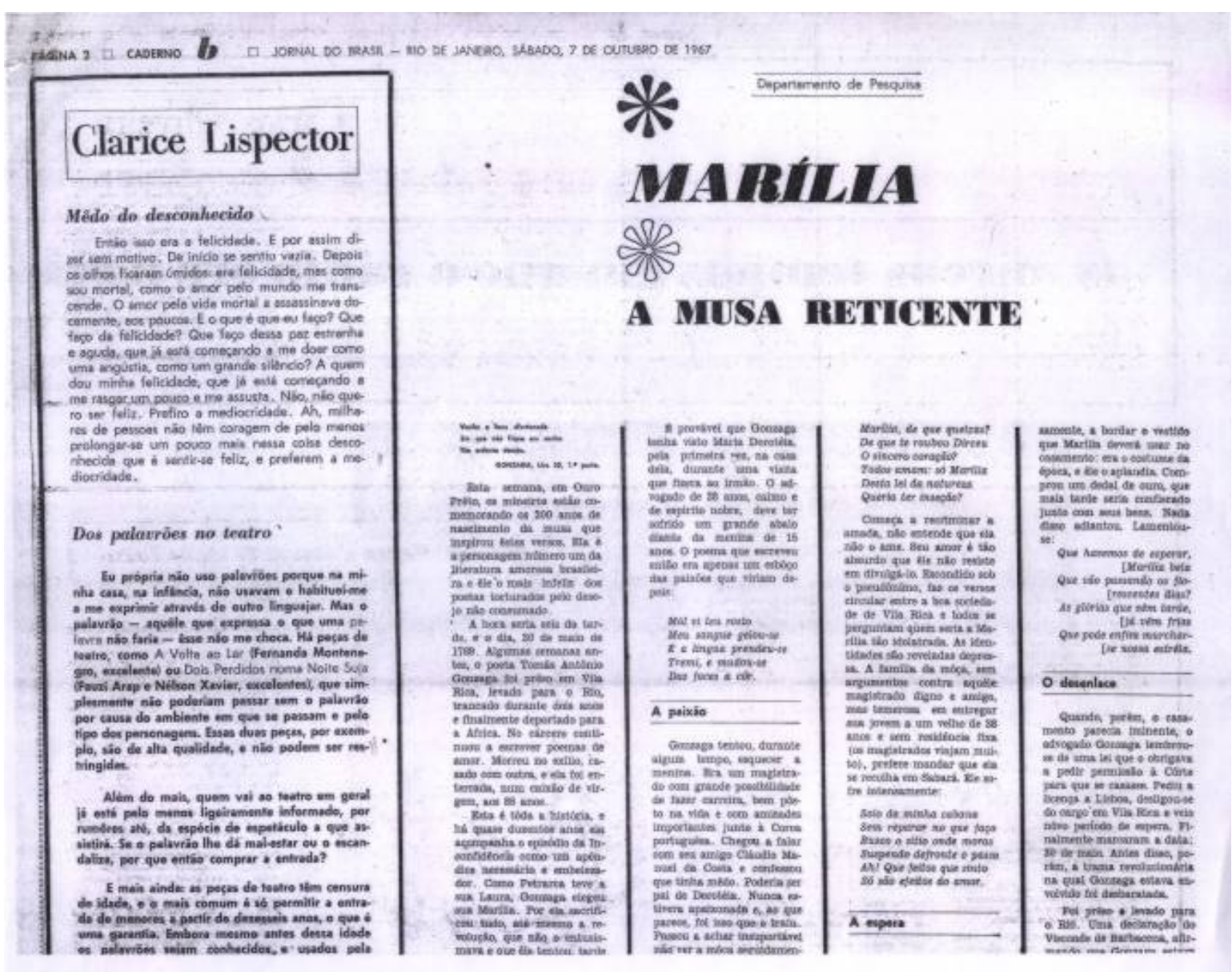


Anexo H MICHALSKI, Yan. O teatro imoral, ou os corcundas por persuasão. Jornal do Brasil, Rio de Janeiro, 30 mar. 1973. Caderno B, p.4.

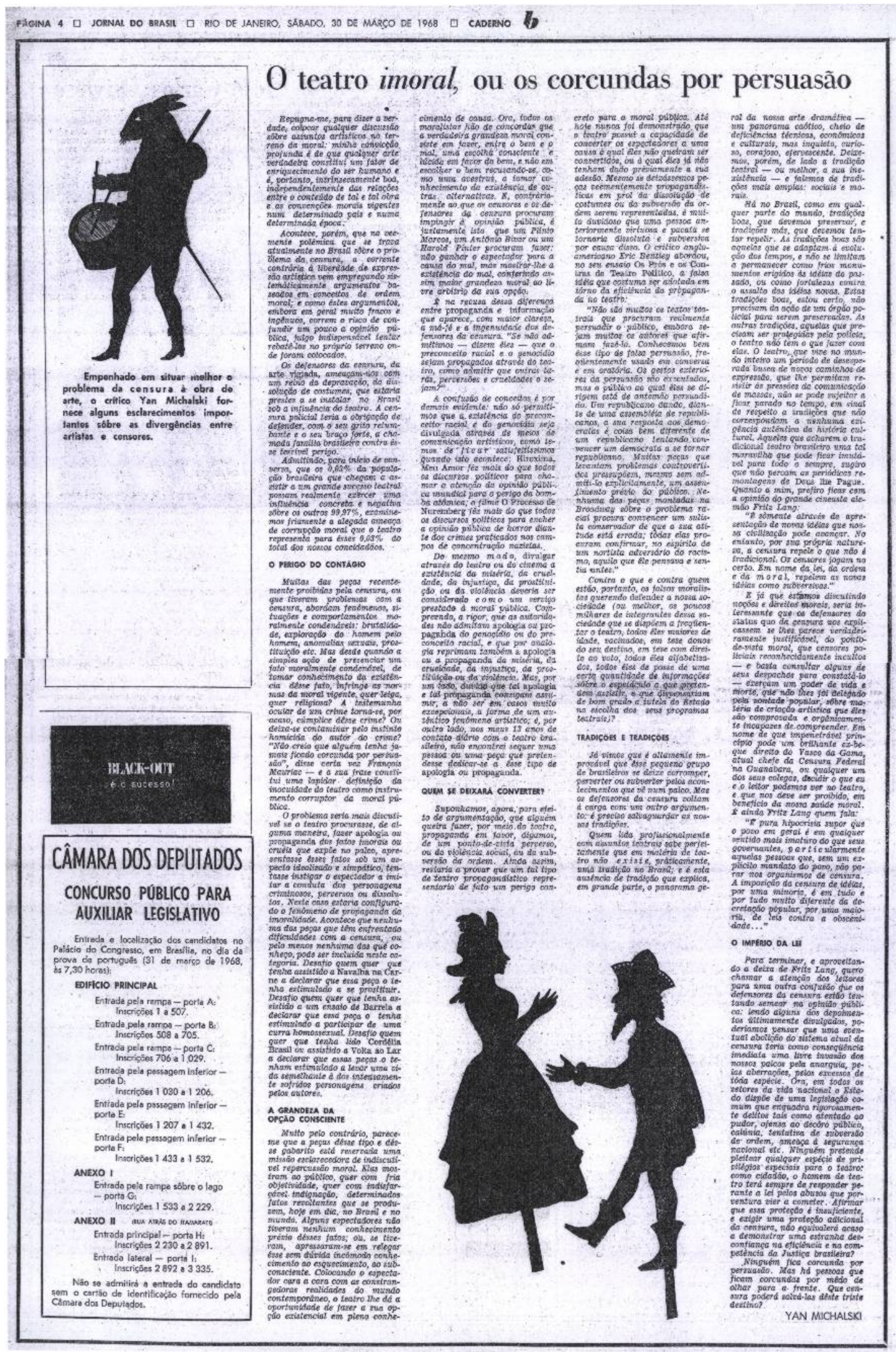


Anexo I Coluna Clarice Lispector, publicada em 17 de fevereiro de 1967.

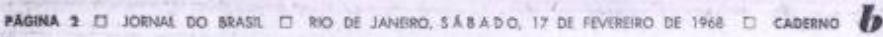

\begin{tabular}{|c|c|}
\hline \multicolumn{2}{|c|}{ Clarice Lispector } \\
\hline \multicolumn{2}{|c|}{ Carła ao Ministro da Educą̧äo } \\
\hline Em primeite lugar que. & Na verdade ou nabe tinha \\
\hline 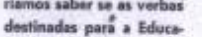 & direito i vage. \\
\hline şa sto ditrfibuldess pelo & $\begin{array}{l}\text { Nobo ontrou do modo ot } \\
\text { gum entrano em sear. }\end{array}$ \\
\hline senhor. So niab, esta carto & 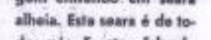 \\
\hline 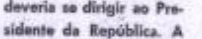 & dos nobsc E outeov folando \\
\hline bato nso me diritio por & 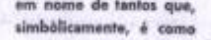 \\
\hline uma especie da pudar, & so. o senher chegense: : \\
\hline mais divelto do falar stom & 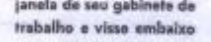 \\
\hline $\begin{array}{l}\text { Minitro da Edveasáo } \\
\text { port is tor sido estudante. }\end{array}$ & $\begin{array}{l}\text { uma mulididio de raparas } \\
\text { - mósen etperando sou }\end{array}$ \\
\hline O sentor has de evitri & verodictum. \\
\hline 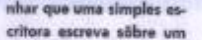 & $\begin{array}{l}\text { Ser estudanto it algo: } \\
\text { muito seria, E quando es }\end{array}$ \\
\hline a sunto tio complexo co. & itswi is tormam, equan. \\
\hline moo doverben pars edva. & $\begin{array}{l}\text { do mais so pense num } \\
\text { meio do ofudar o Brovit. }\end{array}$ \\
\hline $\begin{array}{l}\text { cascho - o que no caso } \\
\text { sipnifiea sbrit vagas pars }\end{array}$ & 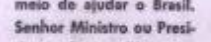 \\
\hline or excedenter. Man opro- & dento do Republitica, im. \\
\hline blema of the grave o por & pedir que lovens entrem \\
\hline vates patefleo quo ment. & 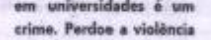 \\
\hline the fillhos om id idede unit. & de polaver. Mas to pale. \\
\hline veriatsria, me loce. & vio certa. \\
\hline O MEC, visando evitur & sidades b curta, obrigan- \\
\hline 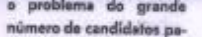 & do \& dimminuir o nümero \\
\hline 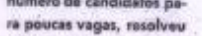 & 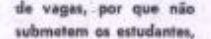 \\
\hline faner censtar nos ediasis & 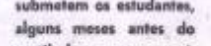 \\
\hline de vestibular que os con. & vestibular, a exames pst \\
\hline 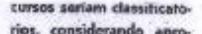 & cotbonicos, a testas voea \\
\hline 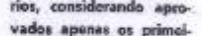 & dionas? luso näo 36 ser. \\
\hline tos colocendes dentros do do & 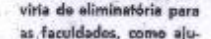 \\
\hline nümero de vogeses existon. & $\begin{array}{l}\text { as facculdodes, comos apu- } \\
\text { daria nos estudentes que }\end{array}$ \\
\hline tes. Este modide impode & estivessem em caminho \\
\hline 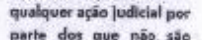 & emado de vocasăa. Este \\
\hline 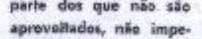 & $\begin{array}{l}\text { ideie partiv do uma essib } \\
\text { danses. }\end{array}$ \\
\hline dindo ne entande que on & So. Senhor soubesse \\
\hline alunos terhamam o impulito & de sacificio que na masio. \\
\hline $\begin{array}{l}\text { de ir as ruas para reivin } \\
\text { dicat as vegas que thes }\end{array}$ & ria das veress a fammiti in. \\
\hline sso negadas. & $\begin{array}{l}\text { reire fax pora que um ras. } \\
\text { pez realixe o seu sonbo, }\end{array}$ \\
\hline Senthor Mininitro oe so & - do ostudar. Sa noubeasso \\
\hline nhor Prosidente: "exce. & da profunda e multas $v^{2}$ \\
\hline dentes" num paik que & 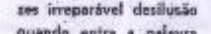 \\
\hline aindo ests em constru & Quendo enire e palevro \\
\hline Chaple que & "excedente", Falei $10 \mathrm{~mm}$ \\
\hline $\begin{array}{l}\text { orginncia do homons a } \\
\text { nutheres }\end{array}$ & $\begin{array}{l}\text { Uma iovem que foi exces } \\
\text { dante, pergunteithe co- }\end{array}$ \\
\hline $\begin{array}{l}\text { mulheres qque o contr } \\
\text { truam? } 56 \text { deixzer antrer }\end{array}$ & 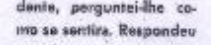 \\
\hline 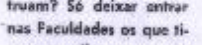 & 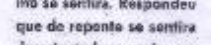 \\
\hline rarem mellhores netas 6 & desorientrada e vaxia, en- \\
\hline Fugir completamansese os & Fuanto no seu Indo rapa: \\
\hline Probleme. O sentor is fol & 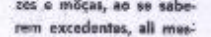 \\
\hline & mo cometaram a chorat. \\
\hline rampre os alunat que fit. & E nom poderiom sair a \\
\hline verminem sendo os me. & va para uma passeate do \\
\hline thores prefissiannii, of & protetso porque sabair \\
\hline Meir capacitades para res. & $\begin{array}{l}\text { que a politio poderia es. } \\
\text { pancalles. }\end{array}$ \\
\hline 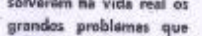 & O senthor subbe o preceso \\
\hline axistern. E nem sempro. & dos livros para provesti- \\
\hline quem tirn as melhores ne & bularen? Sāo carlesimos, \\
\hline tas - oevpa vana voge & $\because 2$ do \\
\hline 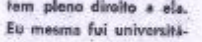 & 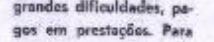 \\
\hline ria e no vestibular classi- & no fim torem sido hió. \\
\hline fiecram-me contre of pri- & \\
\hline No en- & asim. \\
\hline 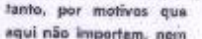 & bolizemu una p p. \\
\hline soquer seguit a profistáa. & $\begin{array}{l}\text { protestio de rapazess a } \\
\text { moças. }\end{array}$ \\
\hline
\end{tabular}

$\mathrm{O}$ cinema sueco depois de Berogimam
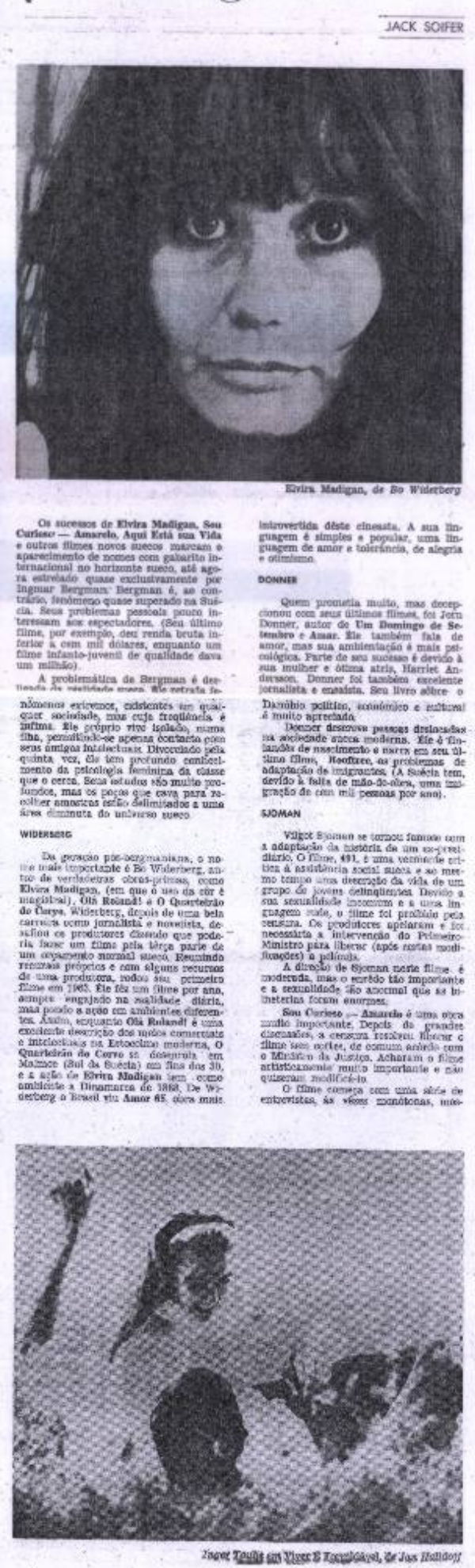

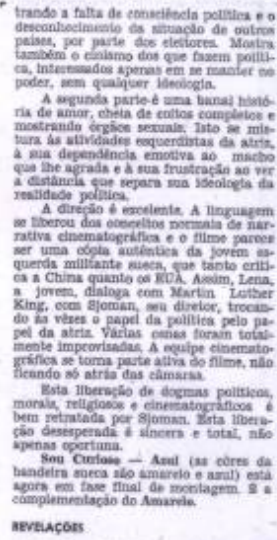

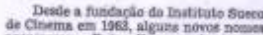

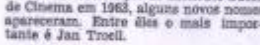
noou

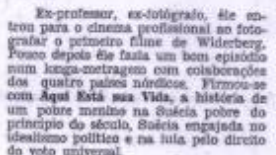

O gue 6 semaladianarie po titme t.

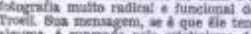

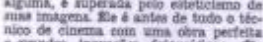

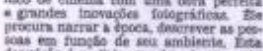
and

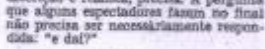
coanra

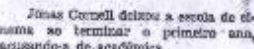

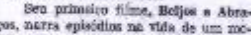

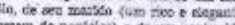

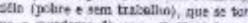

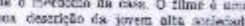

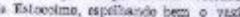

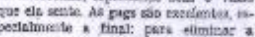

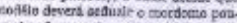

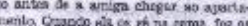

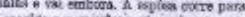

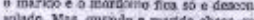

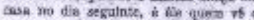

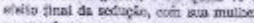
newoorf

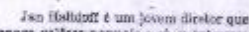

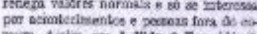

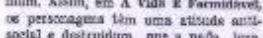

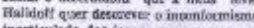

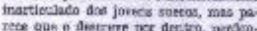

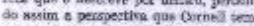

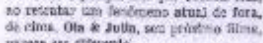
zerreusus

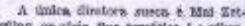

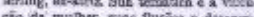

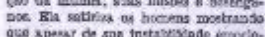

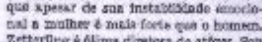

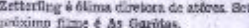
CARISEN

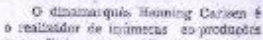

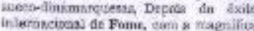

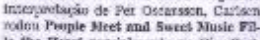

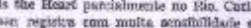

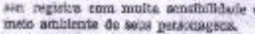


Anexo J JORNAL DO BRASIL. Do protesto à desordem. Rio de Janeiro, 31 mar./1 abr.1968. $1^{\circ}$ Caderno, p.6.

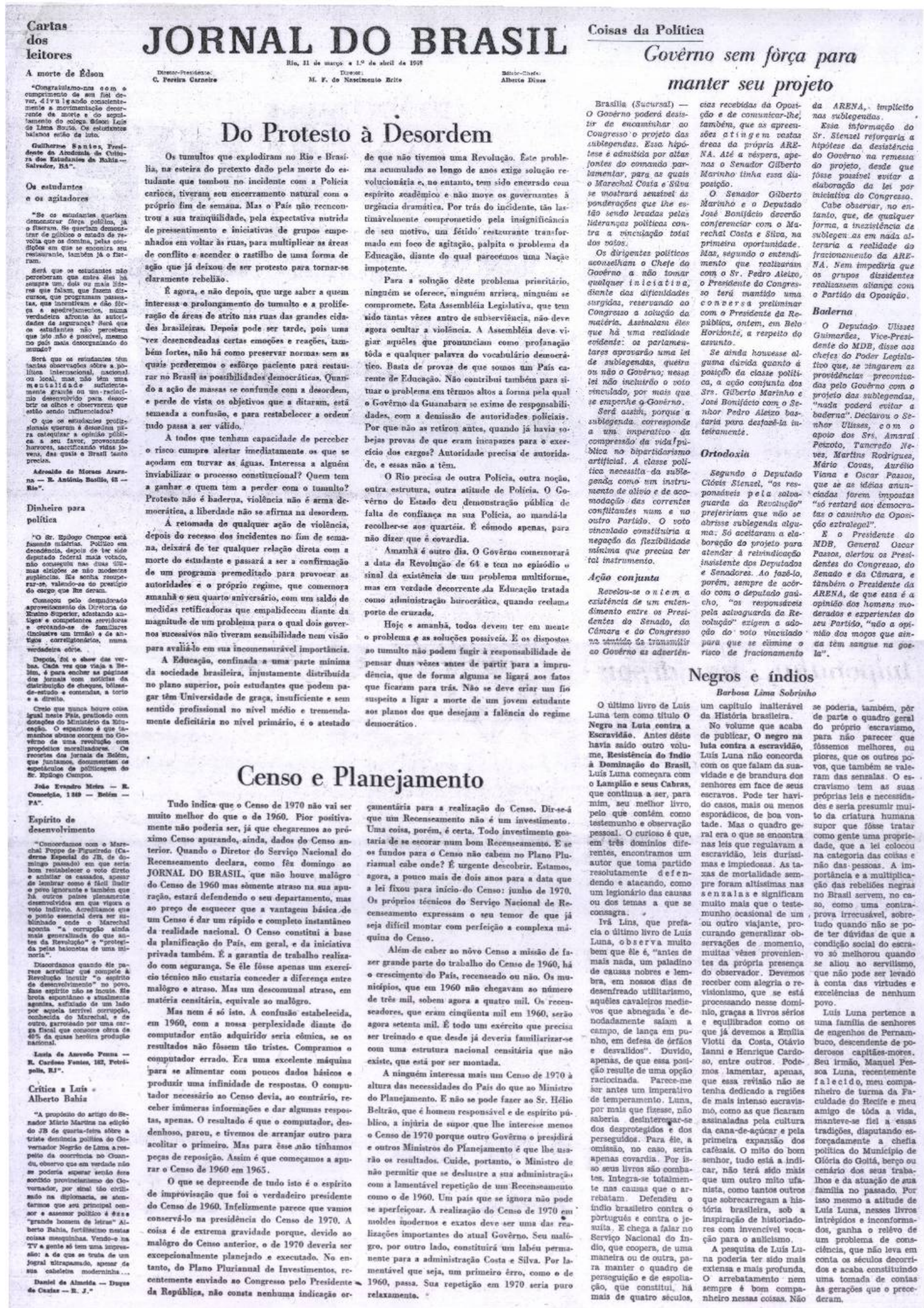


Anexo K Coluna Clarice Lispector, publicada em 31 de maio d 1969.

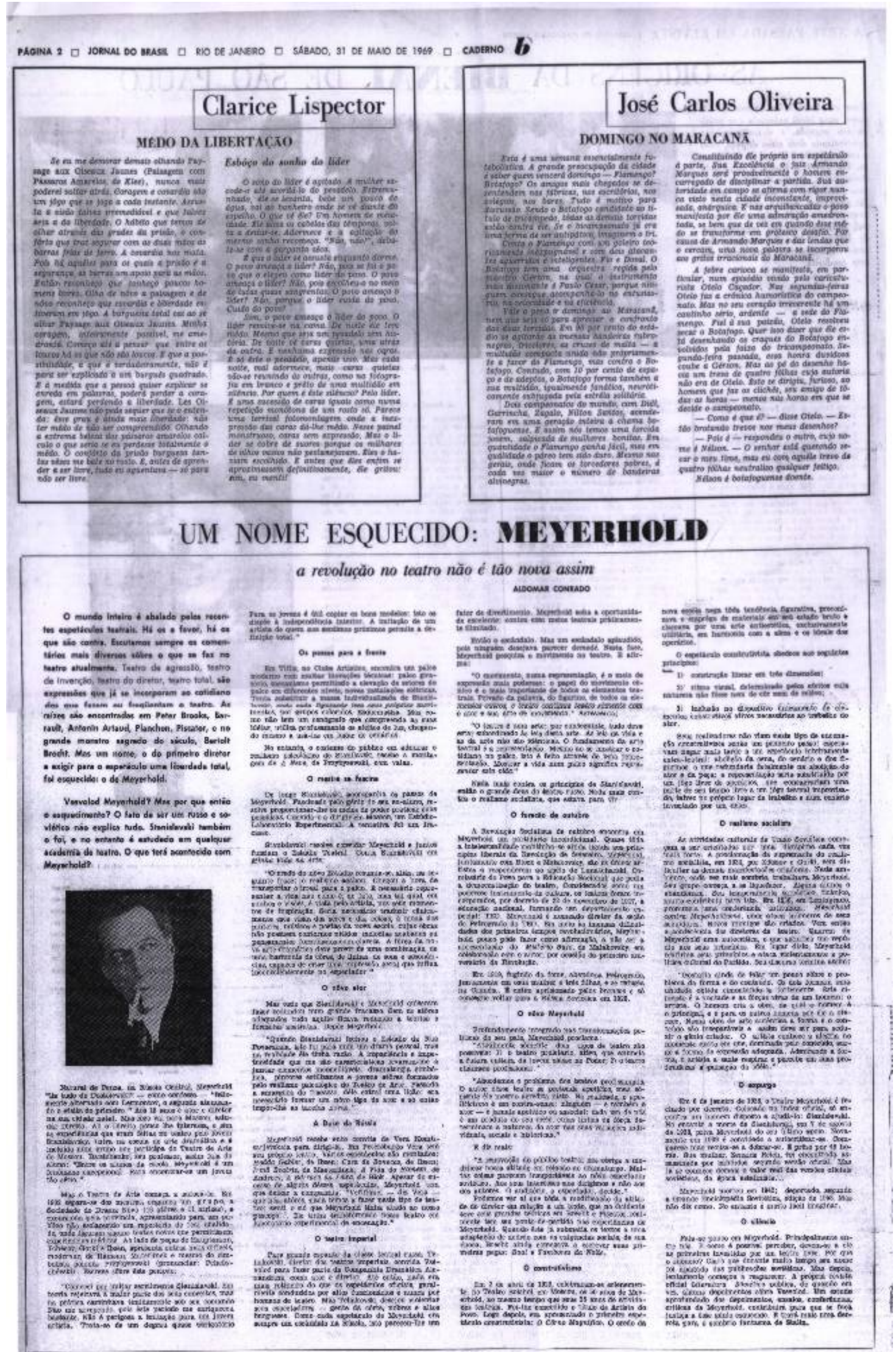


Anexo L JORNAL DO BRASIL. Rio de Janeiro, 14 dez. 1968. Edição Completa.

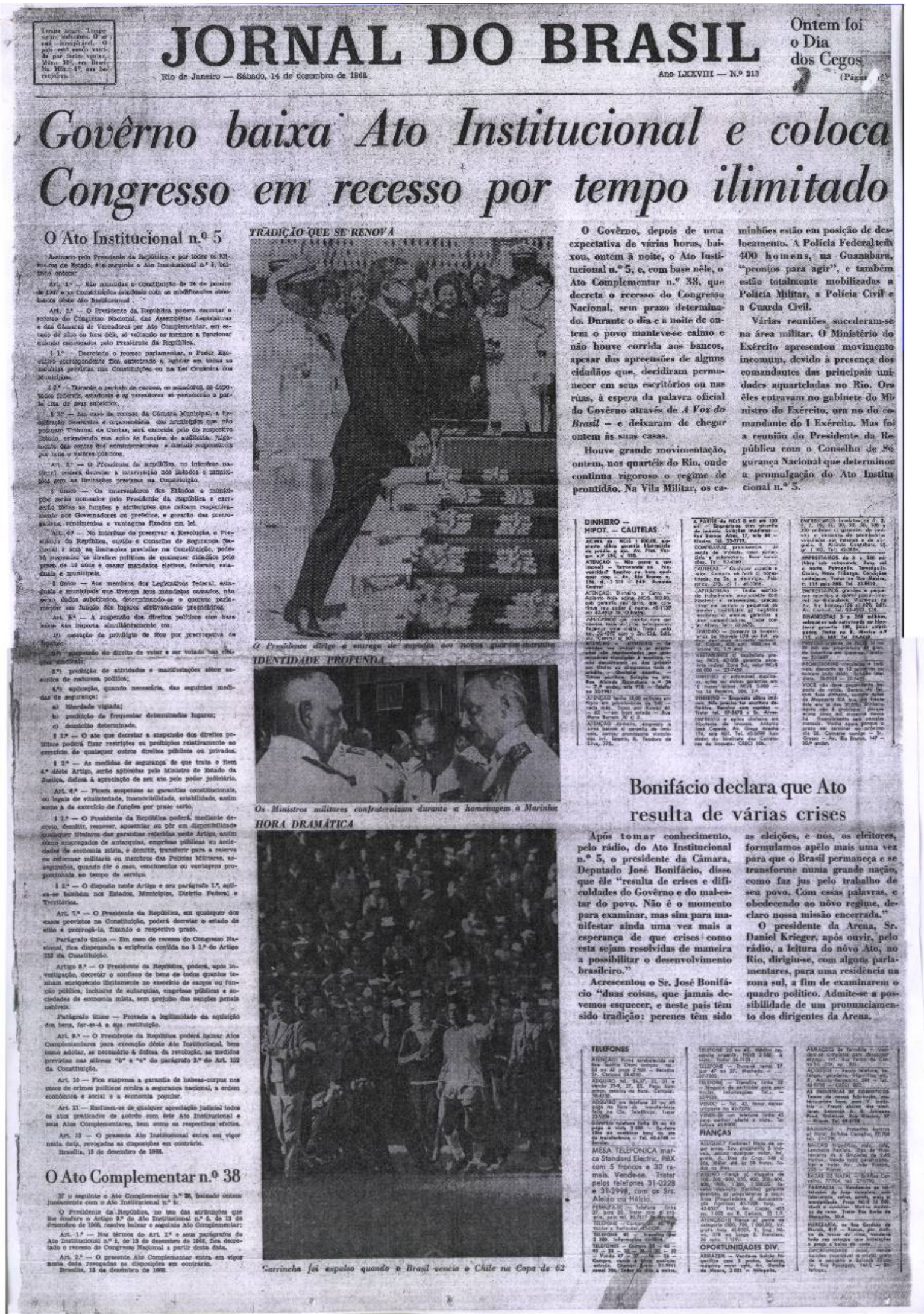


Anexo M Paisagem com Pássaros Amarelos, de Paul Klee.

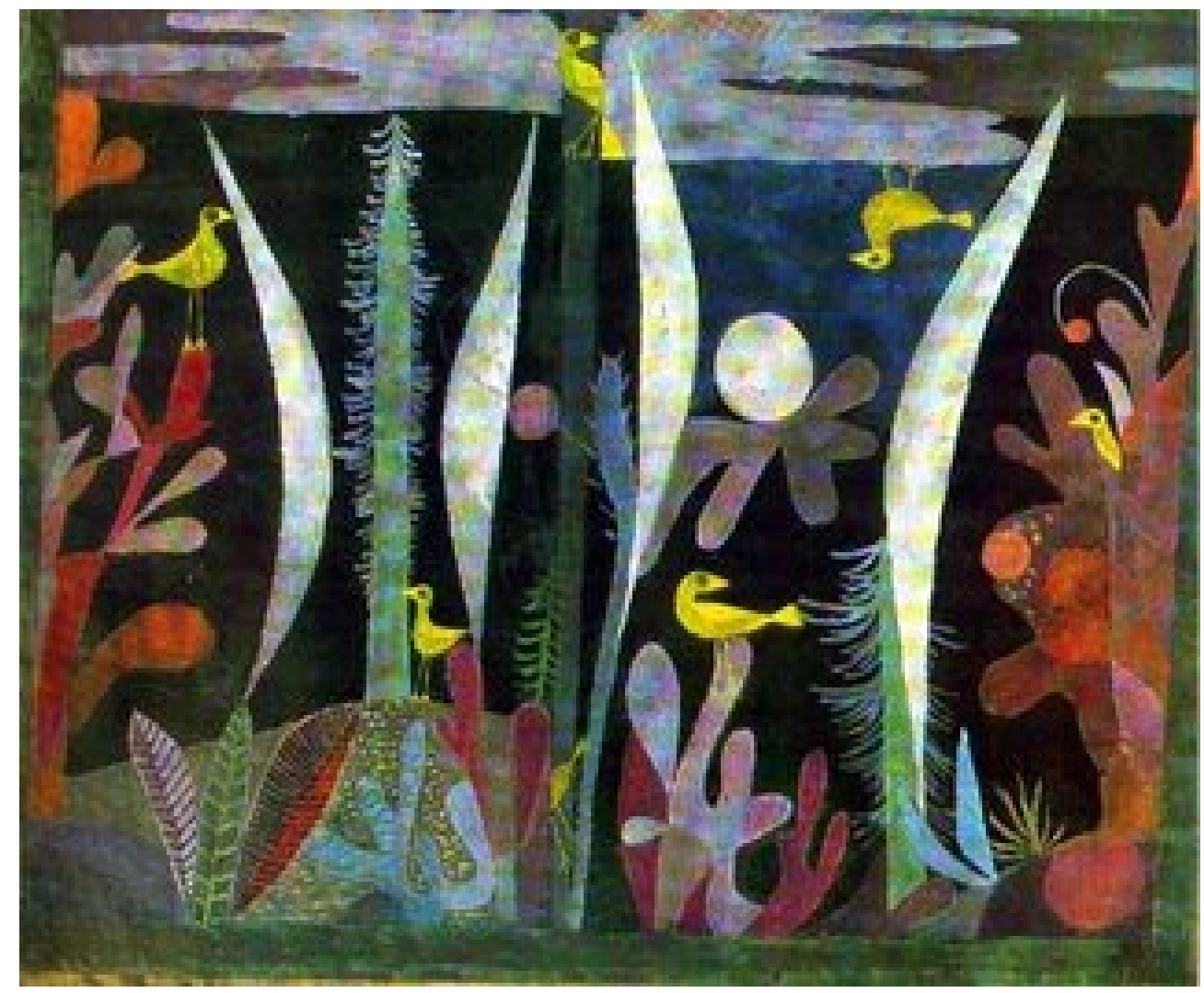

Fonte: http://pitch.cic.unb.br/lcmm/disciplinas/cpmm2006.2/a13/a13.html 
Anexo N JORNAL DO BRASIL. Omissão. Rio de Janeiro, 22 jun.1968. $1^{\circ}$ Caderno, p.6.

\begin{tabular}{|c|c|c|c|}
\hline rtas & \multirow{2}{*}{\multicolumn{2}{|c|}{ JORNAL DO }} & itica \\
\hline 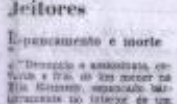 & & & $\begin{array}{l}\text { Crise estudantil dificulta } \\
\text { yuste do sistema politico }\end{array}$ \\
\hline & $\mathrm{Om}$ & ssão & the \\
\hline$\Rightarrow=3$ & 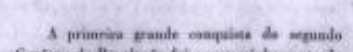 & 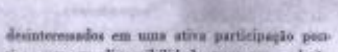 & sind \\
\hline$m$ & 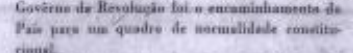 & 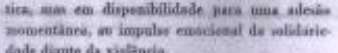 & 5 \\
\hline & 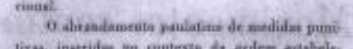 & 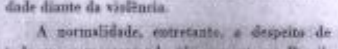 & 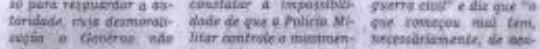 \\
\hline & 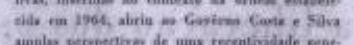 & 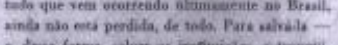 & neowe \\
\hline & 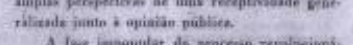 & 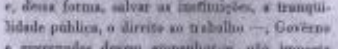 & 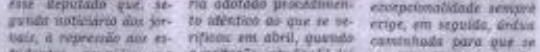 \\
\hline & 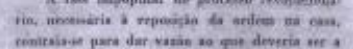 & 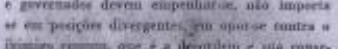 & 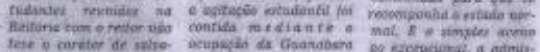 \\
\hline $5 x+2$ & 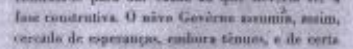 & 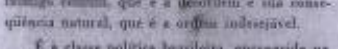 & 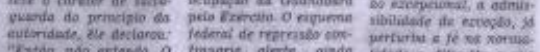 \\
\hline$x=$ & 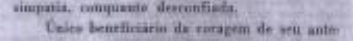 & 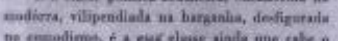 & 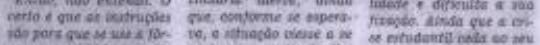 \\
\hline nntis & 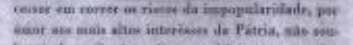 & 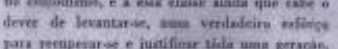 & 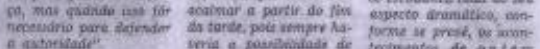 \\
\hline & 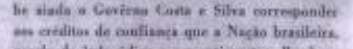 & $-m=0$ & 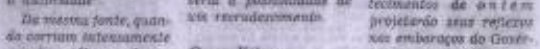 \\
\hline $\operatorname{tin}=$ & 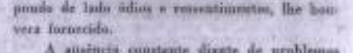 & 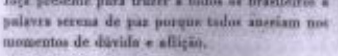 & 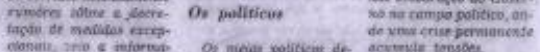 \\
\hline & 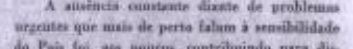 & 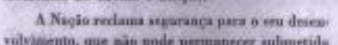 & 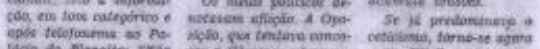 \\
\hline mase & int & 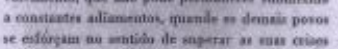 & 40 \\
\hline & 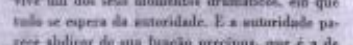 & 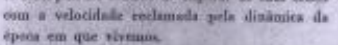 & 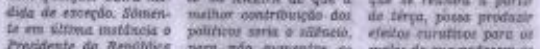 \\
\hline 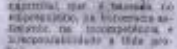 & 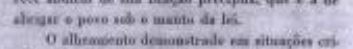 & 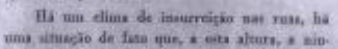 & 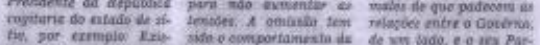 \\
\hline 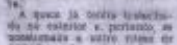 & 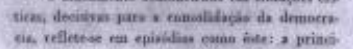 & 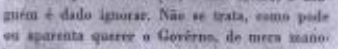 & 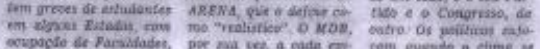 \\
\hline & 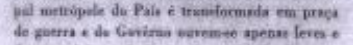 & 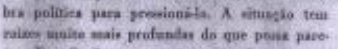 & 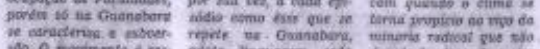 \\
\hline & 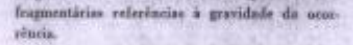 & 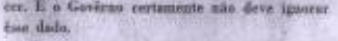 & 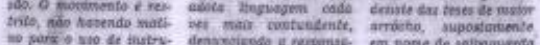 \\
\hline 8 & 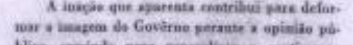 & 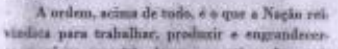 & 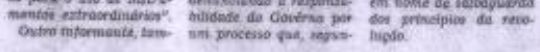 \\
\hline 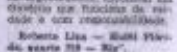 & 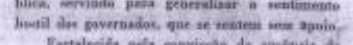 & 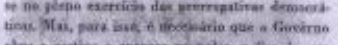 & \\
\hline niturest & 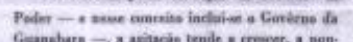 & $=i m$ & Marco \\
\hline$y=$ & 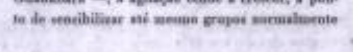 & & \\
\hline & & & \\
\hline mate & & & 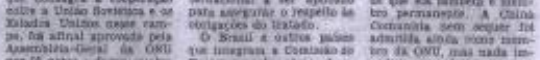 \\
\hline 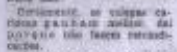 & itiv & & 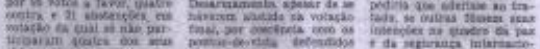 \\
\hline 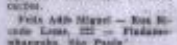 & 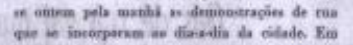 & 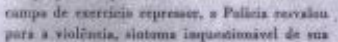 & $6 \%$ \\
\hline & 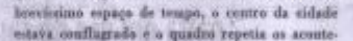 & 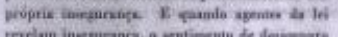 & tistont \\
\hline$=0$. & 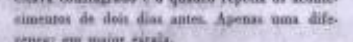 & 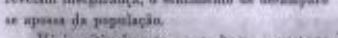 & 4 \\
\hline & 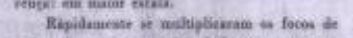 & Hit in & \\
\hline$x=$ & 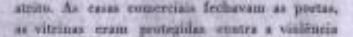 & 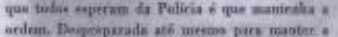 & 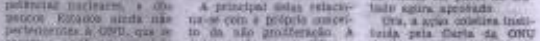 \\
\hline & 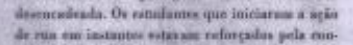 & 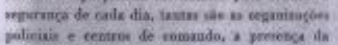 & $=3$ \\
\hline & 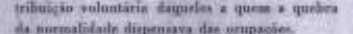 & is & 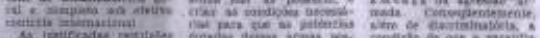 \\
\hline & A montarabe ntabel & whateltos & $5 \pi$ \\
\hline$k=$ & 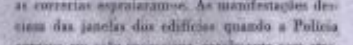 & & 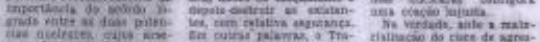 \\
\hline 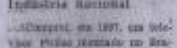 & 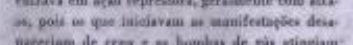 & the cing $x$ & $s$ \\
\hline$n=0$ & on que wil sith & 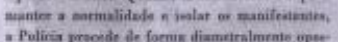 & 8 \\
\hline$x_{x \rightarrow m}=1$ & 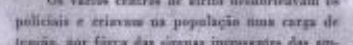 & 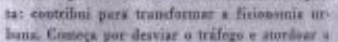 & \pm \\
\hline$=0$ & Gulatian. & popbisch & 동 \\
\hline 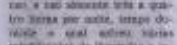 & nnsion & 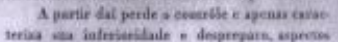 & 5 \\
\hline & 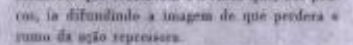 & Patrinbu & $\begin{array}{l}y=2 \\
x=2\end{array}$ \\
\hline & 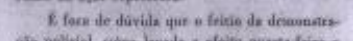 & 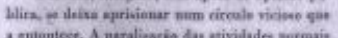 & $\sin x=$ \\
\hline & 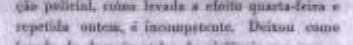 & 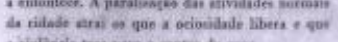 & the dis \\
\hline$=$ & & 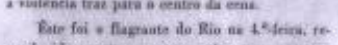 & $3=$ \\
\hline$=-2$ & 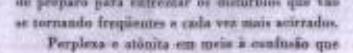 & 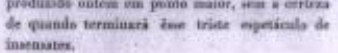 & 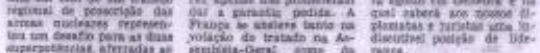 \\
\hline
\end{tabular}

